UNIVERSIDAD NACIONAL DE LA PLATA

FACULTAD DE PERIODISMO Y COMUNICACIÓN SOCIAL

DOCTORADO EN COMUNICACIÓN

\title{
Los usos de las redes sociales en la configuración de las audiencias televisivas de tiras argentinas
}

Tesista: Marisa Rigo

Directora: Florencia Saintout

Año 2015 


\section{INDICE}


CAPITULO I: Televisión argentina___ 9

1. Historia

1.1 Televisión satelital y digital__ 22

2. Audiencia__ 25

3. La tira 38

3.1 Melodrama / Teatro - Folletín - Radioteatro___ $\mathbf{4 3}$

3.2 Telenovela__ 47

CAPITULO II: Redes sociales___ 52

1. Introducción_ 54

1.1Teoría de los seis grados__ 66

1.2 Origen 68

2. Conceptos sobre las redes sociales__ 76

2.1 Tipología de redes sociales___ 98

3.Facebook 100

3.1 Inicio 108

3.2 Aspectos claves__ 115

CAPITULO III: Convergencia mediática____ 118

1. Definición__ 120

1.1 Hipermediaciones 127

2. Narración transmediática 129

CAPITULO IV: Metodología de la investigación___ 143

1. Reflexiones metodológicas

2. Estudio de caso___ 149

CONCLUSIONES _ 230

BIBLIOGRAFÍA _ 240 


\section{INTRODUCCIÓN}


Los usos de las redes sociales en la configuración de las audiencias televisivas de tiras argentinas es una investigación científica que analiza cómo las redes sociales contribuyen a la configuración de las audiencias de una tira.

El mundo digital converge con los viejos medios. El nuevo perfil del espectador multitarea se hace eco de los cambios sufridos por todas las partes que intervienen en la comunicación televisiva con la llegada de las redes sociales.

Las redes sociales pueden ser observadas hoy desde las ciencias sociales como una irrupción en las formas comunicativas que tradicionalmente mantuvieron los mass media. De esta manera, a través de los formatos comunicacionales de la web 2.0, comunidades, redes sociales como Facebook y Twitter, servicios de alojamiento de videos, blogs, etc, surge la posibilidad de que en la sociedad circule información que no es alcanzada por el control de los mass media.

Cuando hablo de control, me refiero a que la información que circula por las redes sociales no puede ser obtenida, en su totalidad por los mass medias. La velocidad con las que se propaga un comentario y sus consecuentes respuestas en el mundo digital, hace que los viejos medios queden detrás de dichas redes, buscando en muchos casos las palabras más provocativas o convocantes pero perdiéndose a su vez enormes cantidades de mensajes que circulan en las redes sociales.

Por su parte, los usuarios se forjaron dentro de una sociedad en la que la televisión ya estaba consolidada como un medio de comunicación junto a la gráfica y la radio, y vieron como Internet fue creciendo hasta llegar a convertirse en otro medio o en un medio de medios, por ejemplo las ficciones seriadas argentinas pueden ser vista a través del sitio del canal que las transmite.

Los formatos televisivos y nuevos soportes comunicacionales ocupan actualmente un lugar central en las estrategias de comunicación. Si bien en la Edad Moderna, los medios de 
comunicación masiva mantuvieron una centralidad determinante, la trayectoria de esta influencia ha ido transformándose cualitativa y cuantitativamente, en correspondencia con la evolución tecnológica de los soportes comunicativos.

Las formas comunicativas de los tradicionales mass media se vieron obligadas a interactuar con las nuevas condiciones impuestas por los diferentes formatos que implicaron el surgimiento, expansión y desarrollo de la web 2.0 en el mundo.

La siguiente investigación se basará en estudiar cómo las redes sociales juegan un rol importante en la construcción, conformación de las audiencias televisivas de diversas tiras argentinas. Cómo estas audiencias a través de Facebook interactúan, discuten, debaten, opinan sobre la trama, personajes, rating, guión, producción de la tira. Cómo las audiencias se convierten en una especie de coproductores de la tira, abandonando la posición de un mero espectador. Qué usos le otorgan a los Facebooks dedicados a las tiras.

El universo de análisis no discrimina franja etaria ni clase social, debido a que considero que no es relevante ese tipo de distinción en una investigación con estas características, porque se focaliza en audiencias en general, que nacieron y crecieron con la televisión a su alrededor, pero que también encontraron en Internet un lugar desde el cual pueden expresarse, debatir sobre lo que están mirando en la televisión, a través de las redes sociales como Facebook.

Asimismo, indagaré si las audiencias con sus comentarios, opiniones marcan la agenda en el rumbo de una tira. La creación de un Facebook oficial por parte de los realizadores de ficciones seriadas, es parte de una plataforma integral en el momento de atraer a las audiencias.

La tira no es indiferente para las audiencias, debido a que le otorgan sentidos a lo que miran por televisión, es decir que resignifican lo que están observando. Dichas audiencias desean debatir, comentar, compartir ciertas cuestiones de la tira. Este contexto hace que los canales de televisión implementen estrategias comunicacionales para atraer a las audiencias a través de las redes sociales. 
Analizaré las publicaciones que las audiencias realizan en Facebook oficiales de tiras argentinas, durante el prime time, que es el horario de mayor encendido, es decir de máxima audiencia. Durante el período entre febrero de 2013 y noviembre de 2014.

Las tiras fueron elegidas por ser ficciones seriadas que apuntan a diferentes públicos, emitiéndose en canales privados y de aires argentinos, identificando como los canales de televisión atraen a diferentes tipos de audiencias permeables al uso de las redes sociales.

Fundamentalmente, los objetivos propuestos que rigen la investigación son:

- Identificar las características de ficciones seriadas argentinas

- Analizar Facebook como un espacio de debate, expresión y configuración de grupos que se interpelan como audiencias.

- Investigar los sentidos que le otorgan las audiencias que participan de Facebook a las tiras.

- Establecer el tipo de intervención que realizan las audiencias que participan a través de Facebook en el desarrollo de las tramas.

- Analizar la identificación de dichas audiencias con situaciones, personajes que se desarrollan en las tiras.

- Analizar las estrategias de comunicación que utilizan los canales de televisión a través de Facebook para con sus audiencias.

La tesis será realizada dentro de los estudios de tipo cualitativos, debido a que la información obtenida es valorada por lo que transmite y no por una muestra numérica arrojada, dejando de lado como variante principal y rectora cualquier cifra obtenida.

Con la investigación se pretende llegar a un tipo de dato descriptivo, informativo, más allá de un dato numérico o un porcentaje. Focalizando la atención en lo qué se dice, en el por qué se dice. 
El método cualitativo es un enfoque que parte de entender la metodología como un proceso de indagación a través de distintas interpretaciones sucesivas y valiéndose de técnicas e instrumentos que permiten la construcción de ciertos datos.

Por lo expresado con anterioridad, con la presente tesis doctoral brindaré aportes en el campo de la comunicación, desde el lugar en el que las redes sociales se convirtieron en un espacio de debate, discusión, expresión sobre lo que la televisión emite, analizando cómo se da el uso de ambos medios de comunicación casi en simultáneo entre las audiencias.

El estudio va a contribuirles tanto a los periodistas como comunicadores sociales, ya que van a disponer de una investigación que analiza la configuración de grupos de audiencias, la construcción del sentido a través de la discusión y el intercambio.

Además, aportará nuevos conocimientos, a las personas que trabajan en la televisión, así como también a quienes se dedican a los nuevos medios. 


\section{TELEVISIÓN}

ARGENTINA

CAPITULO I 
El capitulo se centrará en explicar los inicios de la televisión argentina hasta llegar a la actualidad, con la televisión digital. Cómo fueron sus orígenes, y cómo se fue consolidando a través del tiempo, atravesando diferentes procesos políticos y económicos.

En una segunda parte, se examinarán diversos estudios sobre las audiencias, desde el campo teórico de la Escuela Latinoamericana de Comunicación, trabajando con sus principales referentes, como Guillermo Orozco Gómez. Observando cómo actúan estas audiencias activas que resignifican los contenidos transmitidos a través de la pantalla, sin desprenderse del contexto social, cultural, en el que están inmersas.

Además, se analizarán los cambios de las audiencias con el avance de la tecnología y el surgimiento de las redes sociales, logrando una imbricación con la televisión, y produciendo de esta manera nuevos modos de ser audiencia, desde una perspectiva de la convergencia y de las prácticas culturales.

Por último, se investigará sobre las tiras argentinas, la influencia de la matriz melodramática, conociendo los orígenes del teatro, folletín y radioteatro. Finalizando en el concepto de telenovela y en la evolución de la misma.

Con este enfoque pretendo aportar una reseña de las características centrales del desarrollo histórico de la televisión argentina, junto con una descripción del contexto político en el que se insertó, debido a que no se pueden desentender del marco en el cual se establecieron. La constitución de las audiencias será el eje fundamental para entender cómo se apropiaron de este medio de comunicación, y como se van readaptando a partir de ciertos cambios tecnológicos que se investigarán en el curso de la tesis.

A pesar de que el eje central y articulador de la tesis es el estudio de las audiencias, considero primordial estudiar a las mismas realizando un relevamiento previo de los comienzos de la televisión argentina desde una perspectiva políticacultural. Focalizándome luego en las tiras, debido a que la apropiación de dichas tiras por parte de las audiencias es uno de los objetivos principales de la presente investigación. 


\section{$\mathcal{H I S T O R I \mathcal { A }}$}

En Argentina, el 17 de octubre de 1951 se produjo la primera emisión de la televisión estatal a través de canal 7. Fue durante un acto por el Día de La Lealtad en Plaza de Mayo en el que se emitieron los discursos del Presidente Juan Domingo Perón y Eva Duarte de Perón. La iniciativa respondía a una política estatal desarrollada por el gobierno en ejercicio del poder, es decir que la televisión argentina se instala como un emprendimiento del Estado.

La televisión argentina de aire nace con posterioridad en relación, no solo con Europa o Estados Unidos, sino también respecto de algunos países latinoamericanos en 1950 (Cuba, México, Brasil).

Según la Doctora en Letras, Mirta Varela (1998), el hecho de que la televisión argentina se configure después de otros países produjo una suerte de trauma, debido a que Argentina había sido pionera en el mundo de la radiodifusión. Esta situación marcó sin duda alguna el proceso del desarrollo de la televisión en el país.

Que Argentina haya quedado por detrás de países latinoamericanos como Cuba, México y Brasil en el arribo de la televisión en el país, produjo una marca que dejó una huella importante en la historia de la comunicación en América Latina.

Argentina fue un ejemplo para otros países en el ámbito de la radio, por la infraestructura, producción y desarrollo constante, ofreciéndole al oyente diversos programas de calidad. Que el país no haya sido el precursor en el campo de la televisión, produjo como expresó Varela una gran herida.

El investigador Federico Vazza (2012) enuncia que la llegada de la televisión al país estuvo a cargo del empresario Jaime Yankelevich vinculado a LR 3 Radio Belgrano, emisora que en un principio prestó la infraestructura. La antena se montó en la terraza del edificio del entonces Ministerio de Obras Públicas en la Avenida 9 de julio de Capital Federal. 
Los equipos necesarios para la instalación del canal fueron traídos desde los Estados Unidos por Yankelevich, a quien el gobierno peronista había enviado al exterior para tal fin.

El Licenciado en Ciencias de la Comunicación, Guillermo Mastrini (2001) afirma que a la emisora inicialmente se la conoció como LR3 Radio Belgrano Canal 7, formando parte de la cadena estatal que era administrada por Jaime Yankelevich. Cuando el gobierno decidió llevar adelante en 1954 la privatización de los medios audiovisuales que tenía en su poder, Canal 7 pasó a manos de la Asociación de Promotores de Teleradiodifusión (APT) que pertenecía al grupo Jorge Antonio. Por única vez en su historia y por poco tiempo (hasta el golpe de Septiembre de 1955), LS 82 TV Canal 7 fue formalmente privado, aún cuando sus propietarios estaban directamente vinculados al partido gobernante.

En 1957 se convoca para la adjudicación de 10 licencias de televisión abierta: tres en Capital Federal y una respectivamente en La Plata, Mar del Plata, Bahía Blanca, Rosario, Mendoza, Córdoba y Tucumán. Sin embargo, los nuevos canales privados comenzaron a funcionar en la década del sesenta, cambiando definitivamente el panorama de la televisión nacional. De esta manera, el sistema de la televisión argentina fue mixto (canal estatal + canales privados).

En los primeros años, la televisión argentina se encargaba de transmitir discursos, actos del gobierno y eventos deportivos. Durante la segunda mitad de la década de los noventa, se realizaron telenovelas, ciclos de teatro que atraían al público, marcando un hito por su calidad y contenido, que resultaron ciertamente novedosos para la época.

El poder acceder a los actos, eventos, discursos, telenovelas a través de la pantalla fue un hecho revolucionario para la época, que marcó un antes y un después. Las audiencias esperaban con ansias ver un determinado programa de televisión y el seguimiento de la trama, del accionar de los personajes, en un horario fijo, en el caso de las telenovelas. 
El 9 de junio de 1960 aparece en primer lugar Canal 9, otorgado a la Compañía Argentina de Televisión (CADETE), que integraba un grupo de empresarios, quienes habían adquirido los equipos a la RCA Víctor. Entre ellos estaban el publicista Kurt Lowe y el dueño de los semanarios Radiolandia, Antena y TV Guía, Julio Korn. El primero de octubre del mismo año surgió canal 13, de Proartel, que tuvo al frente al empresario cubano Goar Mestre, quien había sido dueño en los años cincuenta de cadenas de radio y televisión en Cuba. La vasta experiencia de Mestre logró llevar a Canal 13 al primer lugar de audiencia durante varios años.

E1 21 de julio de 1961 nace el tercer canal privado con sede en Capital Federal, Canal 11, adjudicado a la sociedad Difusora Contemporánea (DICON), la cual tenía vínculos con la Iglesia Católica, a través del sacerdote Héctor Grandinetti, quien estaba interesado en los medios de difusión.

Grandinetti estaba bajo las órdenes de sus superiores jesuitas, que le encomendaron la tarea de crear un canal de televisión para llevar el Evangelio a lugares donde estaba ausente. El sacerdote convocó a profesionales vinculados con la Universidad del Salvador (dirigida por los jesuitas), y así pudo conseguir el dinero para que Canal 11 estuviera a cargo de DICON. El emprendimiento televisivo no estaba destinado a la evangelización, pero la religión no estaba fuera del canal. Se intentó consolidar un medio con valores que la sociedad debía mantener vigentes para la realización plena de los ciudadanos.

En sus primeros años, los tres canales privados se repartían el grueso de la audiencia. Aunque la legislación vigente para la explotación de los canales impedía el acceso de capitales extranjeros, las grandes cadenas de Estados Unidos categorización de diferentes núcleos temáticos que se desprendieron de los objetivos de la investigación, mantuvieron estrechos vínculos con sus productoras: Proartel del 13 con la CBS, Telerama del 11 con la ABC y Telecenter del 9 con la NBC5". (Schmucler y Terrero 1996: 12). Por su parte, Canal 7 permaneció siendo del Estado. 
Desde el nacimiento de la televisión argentina hasta fines de los años sesenta, hubo una fuerte presencia de capitales extranjeros en el país, ya sea para la compra de aparatos, insumos, como también de alianzas y acuerdos entre empresarios, aunque muchas de ellas se hacían en forma oculta debido a que la legislación vigente lo impedía. Con el correr de los años los capitales extranjeros se retiran dejándole paso a los nacionales. Alejandro Romay, dueño de LS10 Radio Libertad, se hace cargo de canal 9 en 1963 y años más tarde, en 1970, el empresario periodístico Héctor Ricardo García (dueño del diario Crónica, radio Colonia y la revista Así) le compra canal 11 a la $\mathrm{ABC}$.

En 1966 comienza a transmitir el canal 2 de La Plata, el quinto canal que se ve en Capital Federal y que maneja un grupo empresario dueño de Radio Rivadavia y del diario El Mundo.

La concentración de poder en las manos de unos pocos empresarios, marcó siempre a la televisión en el país desde sus orígenes, como fue el caso de Alejandro Romay, Héctor Ricardo García, entre otros. Esta situación se reproduce y aparece constantemente en la historia de la compra y venta de licencias televisivas.

Durante una década, fueron pocas las primeras personas que pudieron tener un televisor en su hogar. Era común reunirse para ver una transmisión particular, en bares, negocios o la casa de algún afortunado que poseía un televisor.

Ea televisión durante ese período es algo que -se va a ver”, en muchos sentidos más parecida al cine que a la radio. Se trata de un objeto extraño y escaso. Son escasos los televisores cuyo precio los convertía en un símbolo de status, y también el horario -apenas cinco o seis horas desde la tarde y algo más los fines de semana-. Era escaso un único canal. Pero esa escasez también volvía a la televisión un hecho relevante que acentuaba su ritualidad. Ir al club o a la casa del vecino convierten a la televisión en otro modo de sociabilidad urbana" (Varela, 1998: 9). 
La televisión era un objeto de lujo, difícil de obtener por su valor económico, disponibilidad y lejanía, pero que otorgaba un carácter de exclusividad a las personas que podían acceder a ella.

El consumo televisivo en aquella época, creaba un folclore, un ritual en torno al aparato. Las reuniones familiares, con amigos, para ver un determinado programa, permitían una interacción alrededor del televisor. El poder convocante que tenían las diversas transmisiones, influía en las rutinas de quienes se reunían en días y horarios determinados, y que esperaban con ansías ver su producto televisivo favorito.

Destaco la afirmación de la investigadora María Fernanda Longo Elía, al referirse sobre la familia, escuela y el lugar de trabajo como contexto de interpretación de los programas televisivos. Las prácticas de consumo televisivo no se restringen a compartir la emisión del programa, sino que tienen lugar antes y después, continuando a través de formas de conversación social.

Durante la década del cincuenta, ver televisión es una actividad grupal, de desplazamiento hacia las casas de los vecinos, parientes, confiterías, clubes; de prácticas sociales e interacciones novedosas para esa época.

En la década del 60 los géneros están instaurados, y se sabe qué se quiere ver específicamente. Como programas humorísticos (Viendo a Biondi), telenovelas (El amor tiene cara de mujer), periodísticos (Reporter Esso), musicales (Escala Musical), infantiles (El capitán Piluso). Por su parte, las telenovelas presentaban estereotipos cercanos, costumbristas, familiares que provocaban una identificación fácil como La familia Falcón. 
El año 1973 fue determinante debido a que se vencían las licencias otorgadas por el Estado. En esa época se declaran vencidas las licencias en manos de sectores privados, como fue el caso de los canales 9, 11 y 13, y se decide no renovarlas, dando por finalizada la etapa de la televisión privada. Durante la presidencia de María Estela Martínez de Perón los canales pasan a manos del gobierno. El Estado coloca frente a los canales diferentes interventores y se producen enfrentamientos sobre el manejo de los medios. Finalmente los gremialistas apoyaron la estatización. Uno de los objetivos del gobierno militar era dejar establecida una estructura de medios acorde a sus intereses. La Triple A ejerció persecución y censura sobre los canales.

Durante la dictadura militar, a partir del año 1976, el gobierno ejerció la censura y utilizó a los canales como medios de propaganda, para legitimar el régimen y ocultar la violencia, represión, muerte y desaparición que marcaron una época sangrienta de la historia de Argentina.

Al mismo tiempo se crean listas negras de artistas y periodistas, quienes no pudieron trabajar en ningún medio, y muchos de ellos optaron por el exilio.

El Mundial de Futbol del año 1978 marcó el inicio de la televisión color en Argentina, pero solo para el exterior. Recién en 1980 se comenzó a ver en colores, un año antes de que canal 7 se transformara en Argentina Televisora Color (ATC).

En 1981 surge la televisión por cable. Además cambia la posibilidad de relacionarse con el televisor, a través de la aparición del control remoto que permite hacer zapping. 
- $\mathbf{h}$ TV se consume de manera fragmentada y difícilmente una persona vea un programa entero sin ningún tipo de interrupción. Esta característica propia del medio que construye precisamente su lenguaje con fragmentos, se vio reforzada por la aparición del control remoto y el ejercicio del zapping. Podríamos denominar al zapping como una suerte de falso apagar", anula un vínculo con la pantalla mediante la creación de otro. En un principio fue interpretado sólo en su aspecto de recurso del televidente para evitar la publicidad; a esta altura puede ser entendido también como síntoma de la cultura televisiva que mucha gente fue adquiriendo, de su competencia para manejar códigos audiovisuales, de su habilidad para manejar fragmentos" (Landi, 1992: 144).

También llegan las primeras cámaras y videocaseteras, que marcaron un nuevo rumbo en los sistemas de registro, grabación y reproducción de videos caseros, por parte de los televidentes.

La llegada del cable, aumentó gradualmente la oferta televisiva, permitiendo una segmentación de las audiencias. La aparición del control remoto, con el cual uno puede elegir qué ver (dentro de las posibilidades que brindan los canales de tv), fragmentó la programación al permitir ver más de un programa a la vez. Estos factores marcaron el rumbo de una televisión más innovadora, ofreciéndole de esta manera, un protagonismo al televidente.

La aparición de cámaras para uso hogareño, al igual que las videocaseteras, produjeron una independencia en el televidente, quien tenía el poder de grabar y reproducir en el momento que eligiera lo que deseaba de visualizar. Cambian los tiempos de las audiencias, ya no tiene que acomodar sus horarios para mirar su programa favorito, sino que tiene la posibilidad de verlo cuando quiere. Dicha situación fue revolucionaria para esa época, debido a que hay una cierta emancipación, autonomía, libertad, de las audiencias con respecto a la televisión. 
En el año 1982, la televisión argentina realizo la cobertura de la Guerra de Malvinas. Con la vuelta a la democracia (1983) se inicia un nuevo panorama dentro de la televisión argentina. El fin de la dictadura militar en el país, una época marcada por la muerte, desaparición, corrupción. El llamado de elecciones democráticas marcan la apertura de una nueva etapa en la sociedad argentina, al mando del Presidente Raúl Alfonsín.

Durante el gobierno de Raúl Alfonsín solo se otorga en 1984 canal 9 a Alejandro Romay (su antiguo dueño que no había sido indemnizado cuando le expropiaron su productora en 1974) y en 1987 el canal 2 de La Plata a Radiodifusora del Carmen, representado por Héctor Ricardo García, dueño del diario Crónica. Si bien la legislación vigente no permitía que un empresario periodístico accediera a la licencia de un canal, García se presentó como programador y lo controló igualmente.

En la década de los noventa, con Carlos Menem como presidente, se modificó la Ley de Radiodifusión, eliminando las restricciones en la cantidad de licencias, permitiendo que el dueño de un medio pueda acceder a la televisión y tener varios medios en su poder como radios y diarios, conformando de esta manera multimedios. Este cambio se produjo a través de la Ley de Reforma del Estado No 23.696, a través de la cual se proclama la emergencia de las empresas públicas y de servicios del estado ordenándose su posterior privatización.

En 1989, los canales 11 y 13 volvieron a manos privadas. Televisión Federal SA (TELEFE), de Editorial Atlántida (al mando de Constancio y Aníbal Vigil) en sociedad con diez canales del interior, se adjudicaron Canal 11. Por otra parte, Canal 13 fue asignado a Arte Radiotelevisivo Argentino (ARTEAR), dueños del diario Clarín (Ernestina Herrera de Noble, Héctor Magnetto, José Aranda y Lucio Pagliaro y un porcentaje de empresarios de canales del interior).

El período neoliberal permitió la creación de diversos multimedios oligopólicos, concentradores de poder, como Editorial Atlántida, Grupo Clarín. Este contexto marcó una época de manejos fraudulentos, episodios confusos entre los empresarios y el gobierno de 
turno. La posibilidad de un mismo grupo económico de poder comprar una radio, revista o un canal de televisión permitió la conformación de conglomerados multimedios que pretendían ser lideres en obtener el poder de la información, cubriendo todos los medios posibles.

Asimismo, se facilita el desarrollo de los multimedios al no tener ningún límite en el porcentaje de propiedad así como tampoco en la posesión de acciones. Los dueños de medios gráficos podían ser también propietarios de medios electrónicos.

En el transcurso del gobierno de Menen, ingresaron capitales extranjeros al país. Un caso fue Telefónica Internacional (TISA) y el CEI Citicorp Holding que se asociaron con Vigil para formar ATCO (Atlántida comunicaciones) que compró Editorial Atlántida y pasó a controlar las revistas, Radio Continental, los canales de televisión abierta del interior y TELEFE, el canal de televisión abierta que lideró el rating desde 1991, por más de diez años.

A finales del siglo XX, la televisión se consolidó como el medio de comunicación elegido por la gente, dejando atrás a la prensa gráfica y a la radio. Esto se produjo debido a la inmediatez de la transmisión en vivo de los acontecimientos del día, el entretenimiento ficcional a través de las tiras, la expectación grupal (en familia) y sin duda el impacto de la imagen.

La Doctora en Comunicación, Eva Da Porta (2011) afirma que la televisión es valorada como una posibilidad de acceder no sólo a la diversión y al entretenimiento o a la información sino como un modo de aprendizaje, es decir como un conjunto de procedimientos de modelación de sí mismo.

Finalizando el año 1997, Alejandro Romay (Canal 9 Libertad) vendió el canal al grupo australiano Prime TV, y pasó a llamarse Azul Televisión. Cuatro años después se vendió el canal a la empresa española Telefónica Media pero, como ya era dueña de TELEFE, el COMFER la forzó a desprenderse del canal. En ese momento, Daniel Hadad 
(dueño del multimedio Infobae) se hizo cargo del canal. En el año 2007 fue vendido canal 9 al empresario mexicano Remigio Angel González (poseedor de varios medios latinoamericanos).

Por su parte, canal 2 de La Plata, cambió de dueños durante la década menemista. En 1991 el empresario Eduardo Eunekian (a cargo de la operadora de televisión por cable Cablevisión), compró Radiodifusora el Carmen SA y tomó el mando de canal 2, cambiando su nombre por América TV, formando parte del multimedio América. Luego el canal fue comprado por Carlos Avila (creador de la empresa Torneos y Competencias). Con el paso de los años, Avila se asocia al Grupo Uno de Daniel Vila y el político menemista José Luis Manzano, también propietarios de un multimedio. Renuevan la licencia de América 2 y en el año 2007 el empresario y político Francisco De Narváez compra la mayoría del canal.

Si bien la televisión es un negocio, en Argentina y en el resto del mundo, desde sus orígenes, nunca se alcanzó una política audiovisual que se encuentre por sobre las necesidades de capitales concentrados, nacionales y extranjeros.

Con la llegada y el auge de Internet, se comenzó hablar del fin de la televisión, sin embargo la televisión se reinventa constantemente, lucha para superarse en términos tecnológicos, y de esta manera seguir atrayendo a las audiencias.

El contenido y la función de un medio puede cambiar o desplazarse de uno a otro (de contar historias en el radioteatro a la telenovela) y su status social puede ascender o descender, pero una vez que un medio se establece, continúa funcionando dentro de un extenso sistema de opciones comunicativas (...) El cine no mató al teatro. La televisión no mató a la radio (...) Los viejos medios no están siendo desplazados sino que sus funciones y su status están cambiando con la introducción de nuevas tecnologías" (Varela, 2009: 213). 
Si bien es cierto que las audiencias se fragmentaron, esto no significa que Internet desplazará a la televisión, sino que la masividad y éxito de Internet, permitirá que la televisión se vaya retroalimentando, desarrollándose, para seguir manteniendo vigencia. 


\section{TELEVISIÓN SATELITAL Y DIGITAL}

Durante la década del cincuenta y sesenta, los avances tecnológicos permitieron tener una televisión más moderna. En los cincuenta hubo un primer acercamiento a las prácticas de la televisión en color, instaurándose finalmente en los sesenta.

En 1962 entró en órbita el primer satélite de telecomunicaciones llamado Telstar 1, con la transmisión de imágenes en directo desde diferentes países del mundo.

El 25 de mayo de 1969, a partir de la instalación de una estación en Balcarce, se realiza la primera transmisión vía satélite desde el Vaticano. El saludo del Papa Paulo VI a los argentinos, fue considerado como un hecho tecnológico revolucionario para esa época.

Luego, el 20 de julio de 1969 se reciben desde Estados Unidos las imágenes de la llegada del hombre a la luna. Provocando una gran repercusión en todo el mundo, con una audiencia que superaba los setecientos millones de espectadores.

El satélite al igual que el cable fueron innovadores en los mecanismos de emisión y recepción de la televisión, acrecentando la oferta de contenidos y de nuevos mercados. Más tarde, se produjo un cambio trascendental con el arribo de la televisión digital.

La televisión digital produce diversos cambios. Ła señal deja de ser analógica para convertirse en digital, lo que permite mayor aprovechamiento del espacio radioeléctrico, mejor calidad de imagen y posibilita la utilización de nuevos aparatos receptores como la telefonía móvil. Otro de los cambios que produce la televisión digital es la dimensión interactiva, en la que se incorpora información que permite al espectador participar e influir sobre los contenidos a través de un decodificador o set top box, el elemento vital para la decodificación de la señal de la Televisión Digital Terrestre (TDT), que también se trasmite por el espacio radioeléctrico". (Vazza 2012: 1) 
Coincido con Federico Vazza cuando afirma que la digitalización es el cambio tecnológico más importante que está viviendo la televisión y en pocos años se terminará de imponer, redefiniéndola como medio de comunicación masivo.

El poder acceder a lo que se transmite en televisión desde un aparato tecnológico como puede ser una computadora hasta un teléfono celular, es sin dudas un cambio significativo en la evolución de la televisión, impensado durante años.

Una de las características más sobresalientes de la Televisión Digital Terrestre (TDT) es la digitalización de las imágenes y los sonidos, con la consecuente mejora de la calidad de ambos. Además, la televisión digital permite la emisión de más señales en un mismo ancho de banda.

La TDT posee dos categorías: la televisión estándar SDTV (Estándar Definition Television) y la televisión de alta definición HDTV (High Definition Television).

El HDTV tiene una mejor definición, lo que produce una calidad inmejorable sobre los que se transmite en la pantalla. La televisión digital permite en comparación con la analógica, que se puedan corregir las imperfecciones que presenta una transmisión.

En Argentina, durante la presidencia de Cristina Fernández de Kirchner, se creó el Sistema Argentino de Televisión Digital Terrestre (SATVD-T). En el año 2010 comenzaron las transmisiones, con una cantidad pequeña de antenas que se irán ampliando con redes de fibra óptica, y de esta manera poder llegar a diferentes puntos del país. El control está a cargo de la empresa estatal ARSAT. 
Con esta iniciativa se prevé que aumente la cantidad de señales, llegando al año 2020 con una televisión totalmente digital, y de este modo, sustituir a la televisión analógica convencional.

La Tv digital permite la interactividad no solamente vinculada al entretenimiento sino también a la educación con contenidos interactivos, fortaleciendo el eje educativo y cultural.

Dicha interactividad permitirá un menú de navegación donde se podrán seleccionar los goles durante un partido de futbol. Además, contará con esquemas de votaciones, donde se pueda elegir, por ejemplo, al mejor cantante, actor, entre otros.

Finalmente, las normas de televisión digital ofrecerán servicios interactivos con la programación televisiva: visualizar contenidos en una guía de programas, acceder a canales de radio, disponer de visión multicámara (para eventos deportivos en particular), y recibir la señal en equipos portátiles y móviles (receptores en medios de transporte público o en celulares), entre otros beneficios. 


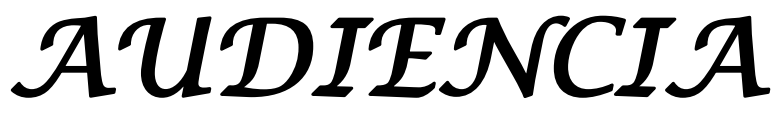

Las audiencias, desde la aparición de la televisión en la década del 50, se sitúan como sujeto y no como objeto frente a la TV. Definiéndola como un ente en situación, condicionado individual y colectivamente, que se va constituyendo como tal y diferenciando como resultado de su interacción con la televisión. Es en este sentido las audiencias de la TV no nacen, sino que se hacen, según Guillermo Orozco Gómez (1990).

Durante décadas, rigió la pregunta ¿Qué hace la TV con su audiencia?, indagando acerca de los efectos de la televisión. La TV se consolidaba como un medio influyente en la constitución de las audiencias. Demostrando que no solamente transmitía información, sino que también producía significados.

Henry Giroux (1981) afirma que la relatividad de la TV en la constitución de su audiencia radica en el hecho de que la audiencia no es un mero recipiente que absorbe todo lo que se le ofrece en la pantalla. Si bien, tampoco es un ente impermeable o capaz en todo momento de tomar distancia crítica de la programación, por el hecho de ser televidente no pierde totalmente sus capacidades, por ejemplo de crítica o de resistencia.

Las audiencias no son pasivas, sino que son activas. Una persona que está frente al televisor procesa la información, le significa algo lo que está mirando. El receptor toma una postura sobre lo que observa en los medios, es decir que no le es indiferente.

La persona que está frente a la pantalla posee conocimientos previos, un bagaje cultural que le permite decodificar lo que se transmite en la televisión. No existen audiencias omnipotentes, permeables, carentes de conciencia crítica, sino que por el contrario, constantemente están buscando su lugar, preguntando y repreguntando, afirmándose como tal. 
El Doctor en Sociología, David Morley, especialista en los análisis de las audiencias y de la recepción, entiende la recepción no desde una concepción lineal medio-audiencia, sino desde la perspectiva que describen el espectador y su ambiente, que condiciona el valor de uso del medio y la forma de ver sus contenidos. Sus aportes son fundamentales para el análisis de la constitución de las audiencias. Por este motivo, será retomado en diferentes oportunidades en la presente investigación.

El receptor le atribuye un significado o sentido a lo que ve. Esta actividad depende de muchos factores, por ejemplo un mismo espectador puede ser activo según las distintas situaciones televisivas y extra televisivas. Sería conveniente no concebir a la audiencia como una masa indiferenciada de individuos sino como una compleja configuración de subculturas y subgrupos superpuestos, en los que se sitúan los individuos. Si bien no podemos adoptar una posición determinista y suponer que la posición social de una persona ha de determinar automáticamente su marco conceptual y cultural, debemos tener en cuenta que los contextos sociales suministran los recursos y establecen los límites dentro de los cuales operan los individuos" (Morley 1996: 13).

Las audiencias no pueden desprenderse de su contexto social, cultural en el momento de decodificar mensajes provenientes de la televisión. Sus lecturas individuales están enmarcadas por sus formaciones y prácticas, esto evidencia por qué un miembro de una clase particular decodifica cierto mensaje de un modo diferente de un miembro de la misma clase.

Siguiendo esta línea de David Morley, Alejandro Grimson y Mirta Varela, afirman que el mensaje proveniente de los medios que le llega a las audiencias es polivalente, en la medida en que, para leerlo, el receptor hace fluir hacia él tanto sus antecedentes individuales, biografía y psicología peculiares, cuanto sus antecedentes de clase.

La interpretación y la comprensión televisiva se construyen socialmente, debido a que mirar televisión es también un hecho social. Se conversa de los que se vio en televisión con compañeros de trabajo, vecinos, es decir con el contexto que los rodea. 
David Morley afirma que cuando el espectador individual se encuentra frente a una serie de signos que fueron organizados y estructurados por emisores profesionales, el espectador individual no llega a ese momento desnudo de cultura; es decir que aborda el texto aportando su propia serie de códigos y marcos culturales, según los cuales concibe lo que ve, marcos y códigos derivados de su situación y sus orígenes culturales y sociales.

En el momento de mirar el programa, los códigos y estructuras que este ofrece se encuentran con los códigos y discursos de que dispone el espectador, y necesariamente pasan por el filtro de estos últimos. El sentido que produce este encuentro varía según el grado en que los distintos miembros de la audiencia se inserten en diversos tipos de códigos y discursos. El sentido del programa que genere el espectador dependerá de la estructuración que el programa recibió de sus emisores y de los códigos de interpretación que el espectador aporte al texto. El sentido emerge del diálogo o encuentro entre el producto y su espectador.

Dentro del campo de la comunicación cambia la pregunta ¿Qué hace la TV con su audiencia? por ¿Qué hace la audiencia con la TV?.

Guillermo Orozco Gómez se enmarca dentro de la línea de investigación latinoamericana en comunicación, en una teoría que va a analizar la recepción, y que es llamada Mediaciones, término que ya había definido Jesús Martín Barbero como la instancia cultural desde donde el público de los medios produce y se apropia del significado y del sentido del proceso comunicativo.

Con anterioridad, Theodor Adorno, filósofo alemán y máximo representante de la Escuela de Frankfurt, quien realizó sus estudios sobre la televisión en los años 50, enunció que en el estudio de productos culturales, la categoría básica por utilizarse no es la de la comunicación, sino la de mediaciones, que es inherente al objeto mismo y suscita la cuestión de cómo aspectos estructurales, posiciones, ideologías y todo lo demás de la sociedad se impone a la misma obra de arte. 
Por su parte, el intelectual galés, Raymond William desde la Escuela de Birmingham, también trabajó con dicho concepto. Haciendo foco en el tema de la cultura, afirmando que existe una cultura hegemónica, cuyo poder es consensuado en el imaginario colectivo, pero en diferentes prácticas culturales surgen resistencias generadas por otras resignificaciones. Aquí entra en juego el concepto de mediación, que implica dar otro sentido a los conceptos desde la propia experiencia.

A través de la Escuela de Frankfurt, Theodor Adorno, Max Horkheimer, Herbert Marcuse, entre otros, denunciaron la manipulación que ejercían las empresas de comunicación, y el estado sobre las audiencias. Persuadiéndolas, alienándolas, homogeneizándolas, para influir directamente en sus necesidades.

El cambio que atraviesa la conceptualización de las audiencias, de seres pasivos, manipulables por los medios, a audiencias definidas como productoras de sentido, que reivindican o desmitifican lo que se transmite en la televisión, permite posicionarse en un lugar protagónico en su relación con los medios de comunicación.

Asumo que es necesario hacer dialogar a la Escuela de Frankfurt con la Escuela Latinoamericana de Comunicación, debido a que la primera tuvo influencia en los estudios de comunicación en América Latina, permitiendo el desarrollo de teorías como la Recepción activa y las Mediaciones.

En el transcurso de la década del ochenta y noventa se comienza a consolidar los Estudios Culturales Latinoamericanos, retomando los aportes de los estudios culturales y cualitativos de audiencias, siendo Guillermo Orozco Gómez, Néstor García Canclini los principales exponentes de esta corriente, a través de diversas investigaciones sobre medios y audiencias.

Desde la cultura como mediadora, la teoría de Orozco Gómez explica qué es lo que interviene entre un público determinado y los medios, y para analizar esto, la teoría de las mediaciones va a indicar qué elementos hay que prestarle atención para ver lo que está 
mediando entre el público y el medio. Las mediaciones son definidas como las articulaciones que configuran al sujeto frente a la televisión.

La primera premisa que parte de la teoría de las mediaciones, es que el acto de recepción no es un acto que pueda pensarse en sí mismo, porque la recepción, el momento en que nos sentamos frente a la televisión está marcado por señas de la cultura, sociedad, previas a ese momento. Es imposible dejar afuera todas estas marcaciones en el momento de ver televisión, ya que esto forma parte de la vida misma.

Cómo segundo lugar, el acto de recepción no se termina en el momento de dejar de ver la televisión, sino que se sigue pensando, creando sentidos en relación al mundo, luego de ver televisión.

En tercer lugar, los receptores le dan sentido a lo que configuran los medios a través del modo de interactuar con el mundo. El televidente es aquel sujeto que va constantemente construyendo sentido a partir de lo que ve, de lo que recepciona.

Desde estas premisas Orozco Gómez va a explicar las teorías de las mediaciones, las cuales están atravesadas por una serie de diferentes variables que serán expuestas a continuación:

\section{Mediación Videotecnológica:}

No todo se analiza desde el lugar de las audiencias sino también hay un lugar del lenguaje que aportan las industrias culturales, es decir cómo las industrias culturales interpelan a las audiencias. En esta interpelación va a haber una cuestión imponente, las características de la tecnología en juego. 


\section{Mediación Individual o Referencial:}

Es una variable que interviene entre la televisión y los televidentes a partir de la idea de la referencia. Las referencias son marcas con las cuales el sujeto se identifica estructuralmente. Son marcas que tienen los sujetos a la hora de enfrentarse con una propuesta de las industrias culturales.

Las marcas estructurales son el género, la clase social, la etnia y la edad. Son aquellos lugares que el sujeto no elige, sino que el sujeto está marcado previamente a su existencia. Estas marcas van a influir en el proyecto de ver televisión, el sentido que se le da a la televisión de una manera distinta.

\section{Mediación Situacional:}

La situación en la cual vemos televisión o nos relacionamos con los medios es la situación desde la cual le damos sentido a lo que vemos. No es lo mismo si miramos televisión solos o acompañados por familiares, amigos, tampoco es igual ver un programa en la casa, sentado frente al televisor durante toda la duración del mismo, que verlo por momentos, mientras se está realizando alguna tarea.

\section{Mediación Institucional:}

Los hombres y mujeres a medida que actúan con el mundo crean sentidos sobre este. A lo largo de su crecimiento, las personas van pasando por diferentes instituciones, por la escuela, la Iglesia, los clubes, la familia; y en cada una de estas se crean guiones de comportamiento, desde los cuales se mueven dentro de las instituciones. 
Con el tiempo, se crea un guión de cómo comportarse frente a los medios de comunicación, para ser audiencias, para saber qué esperamos o que no esperamos sobre ésta. La forma de ser televidentes se va aprendiendo, con el tiempo, a partir del aporte que tiene el aprendizaje en otras instituciones.

Los distintos tipos de mediación entran en juego en la interacción con la televisión y conforman audiencias específicas en el proceso de recepción. Las mediaciones actúan en conjunto, nunca por separado.

Las mediaciones expuestas por Guillermo Orozco Gómez pueden seguir siendo utilizadas, pero necesitan ser actualizadas. La irrupción de las nuevas tecnologías, redes sociales, piden constantemente una revisión de estas mediaciones y consecuentemente del ser audiencia.

Con el paso de los años, el avance de la tecnología y la consecuente aparición de las redes sociales posibilitaron una imbricación con la televisión, produciendo nuevos modos de ser audiencia. Estamos ante una audiencia más selectiva, que elige lo que quiere mirar de acuerdo a sus gustos o preferencias, diferenciándose entre ellas.

El carácter activo de las audiencias sumado al avance de la tecnología, permite mirar televisión desde la computadora u otros dispositivos electrónicos, solo o rodeado de gente. Eos modos de estar, siendo audiencias, no se agotan con lo nuevo, en este caso con las nuevas pantallas, ni con otras formas de estar conectados a los dispositivos tecnológicos, ni se hacen obsoletos unos a otros con la era digital, sus convergencias e interactividades. Coexisten" (Orozco Gómez 2011: 379).

Las audiencias, viven actualmente la era de los hipermedios, es decir un sistema integrado de diverso aparatos tecnológicos, que trabajan en conjunto como por ejemplo la unión del televisor, con la computadora, Internet, celular. Esta interconexión le da a las 
audiencias un nuevo rol dentro de los medios, aumentando su ser activo, debido a que ella decide qué ver, cómo ver y desde dónde ver.

Si bien estamos en una era digital, marcada por el avance tecnológico, no debemos olvidarnos de que la dimensión analógica sigue existiendo, dicha dimensión constituyó a las audiencias como tal. Algunas audiencias que no nacieron en la era digital, pudieron insertarse en ese mundo, sin embargo, otras no lo hicieron. Por este motivo, hay que ser cauteloso en el momento de generalizar a las audiencias, porque si bien existe una era tecnológica, no todas las audiencias se insertaron.

Con el término dimensión analógica me refiero a las audiencias que presentan un uso escaso o nulo de los nuevos medios como Internet, las redes sociales, aparatos tecnológicos inteligentes como tablets y smartphones; priorizando la utilización de medios tradicionales como el televisor, es decir, continuando con los modos de ver a través de una tecnología analógica lineal.

El Doctor Carlos Scolari se refiere al pasaje de audiencias a usuario, quien está influenciado por el mundo digital, pero también conlleva la marca analógica. Con esto quiero decir que, tanto el mundo digital como el analógico pueden coexistir, el surgimiento de uno no impide la existencia del anterior. 
Un caso representativo fue la tira emitida por El Trece Tv, Farsantes ${ }^{1}$. Un grupo de fanáticas de la historia de amor principal, entre dos actores, Julio Chávez (Guillermo) y Benjamín Vicuña (Pedro), reclamaban ante el edificio de la productora Pol- Ka, por la muerte del personaje interpretado por Vicuña, con la consecuente disolución de la pareja protagónica.

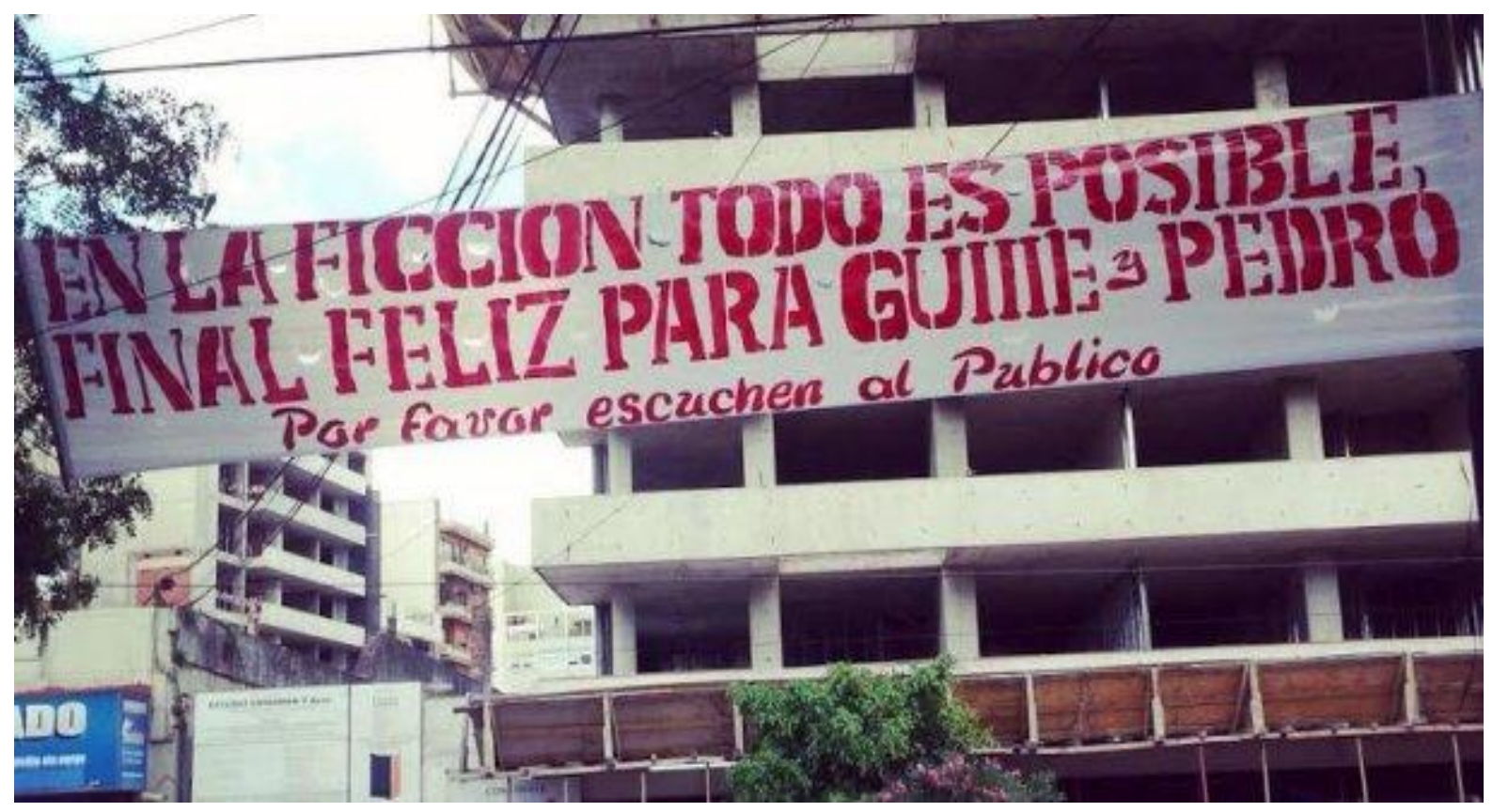

${ }^{1}$ Tira argentina, producida por Pol-ka producciones. (Adrián Suar y Fernando Blanco). Comenzó a emitirse el miércoles 26 de junio de 2013 y finalizó el 12 de febrero de 2014, en el prime time de El Trece Tv. Protagonistas: Julio Chávez, Facundo Arana, Griselda Siciliani, Benjamín Vicuña y Alfredo Casero. Guionista: Carolina Aguirre y Mario Segade. Director integral: Daniel Barone y Jorge Bechara. La historia se desarrolla en un estudio jurídico, cuyo dueño es el prestigioso abogado Guillermo (Julio Chávez), quien luego de estar alejado de su profesión, decide reabrir su estudio, en el que tendrá como socio a Pedro (Benjamín Vicuña), con quién tendrá una relación amorosa, a pesar de que ambos tienen sus respectivas familias .Por su parte, Pedro descubre lentamente un sentimiento profundo hacia Guillermo, a pesar de que nunca había tenido una relación homosexual. También forman parte del buffet: Alberto, un ex presidiario a quien Guillermo sacó de la cárcel y forjaron una gran amistad. Gabriela, es una joven abogada, que lucha incansablemente por la justicia y se terminará enamorando de Alberto; y Marcos, un abogado que siempre se encuentra al límite de la ley en el momento de resolver los casos que se le presentan. 


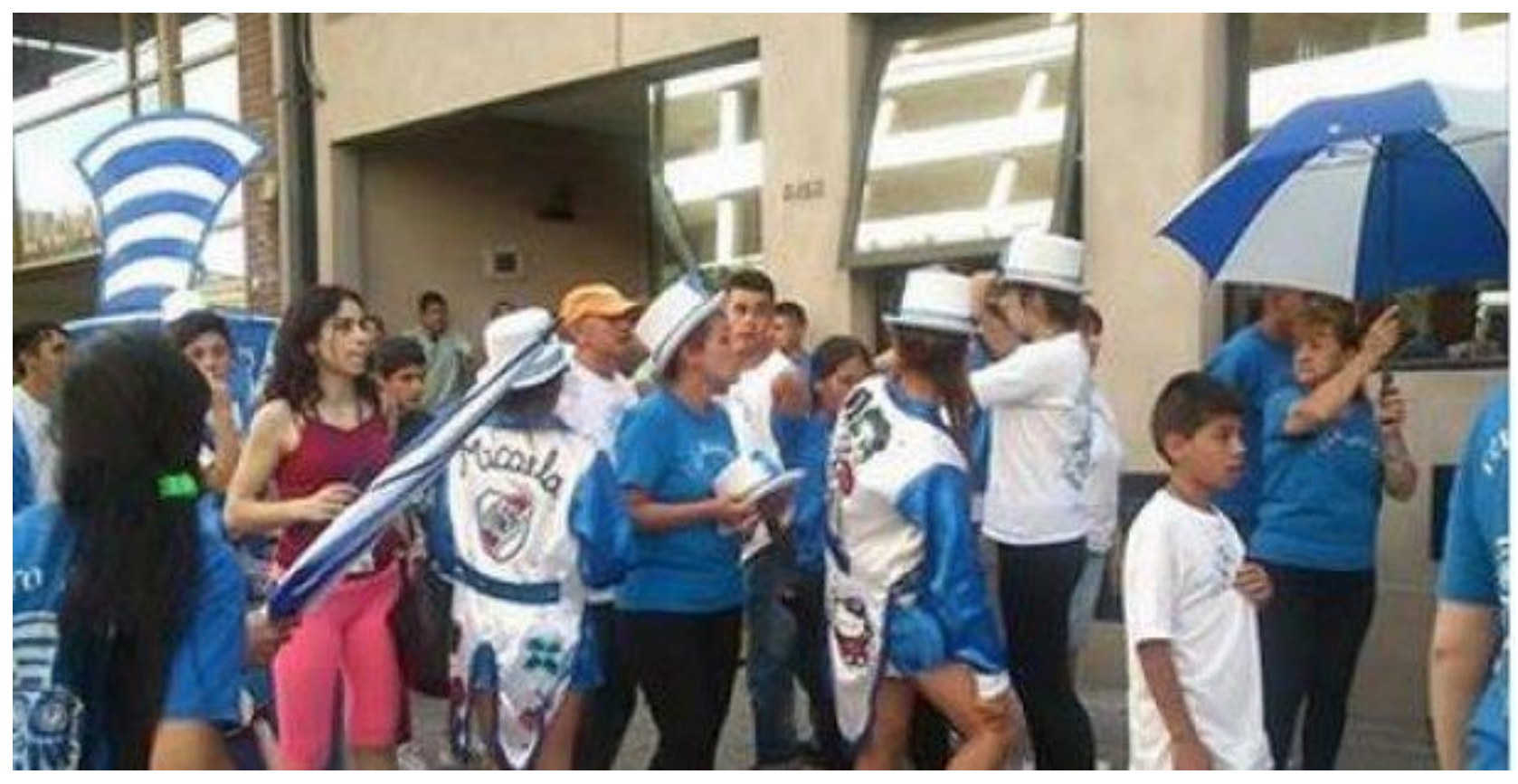

La convocatoria que se realizó a través de las redes sociales como Facebook y Twitter, contó con un pasacalle y una murga. ${ }^{2}$ Los sucesivos mensajes en las redes sociales de los usuarios en contra del rumbo de la historia, permitieron que ellos mismos, a través de las redes decidieran traspasar la pantalla, y llevar su reclamo a la vía pública. Hacerse presente frente a la productora para que escuchen sus quejan, sin dejar de debatir a través de las redes sociales, quejándose por el desenlace de la historia de amor de los protagonistas. Fue una iniciativa desarrollada en las redes, que trascendió por un momento el espacio virtual, pero que continuó manifestándose a través del plano digital.

\footnotetext{
${ }^{2}$ En http://www.ratingcero.com/notas/111470-la-furia-los-fans-vicuna-y-chavez-piden-el-regresopedro-farsantes (Consultada: 10 diciembre 2013).
} 
Sin embargo, no todos son reclamos, debido a que cuando las fans supieron que el actor Benjamín Vicuña regresaría a la tira para grabar el capitulo final de la ficción, las seguidoras expresaron su contento, a través de la cuenta de Twitter que nuclea a las fanáticas del actor, denominada "Vicunitas_arg".3

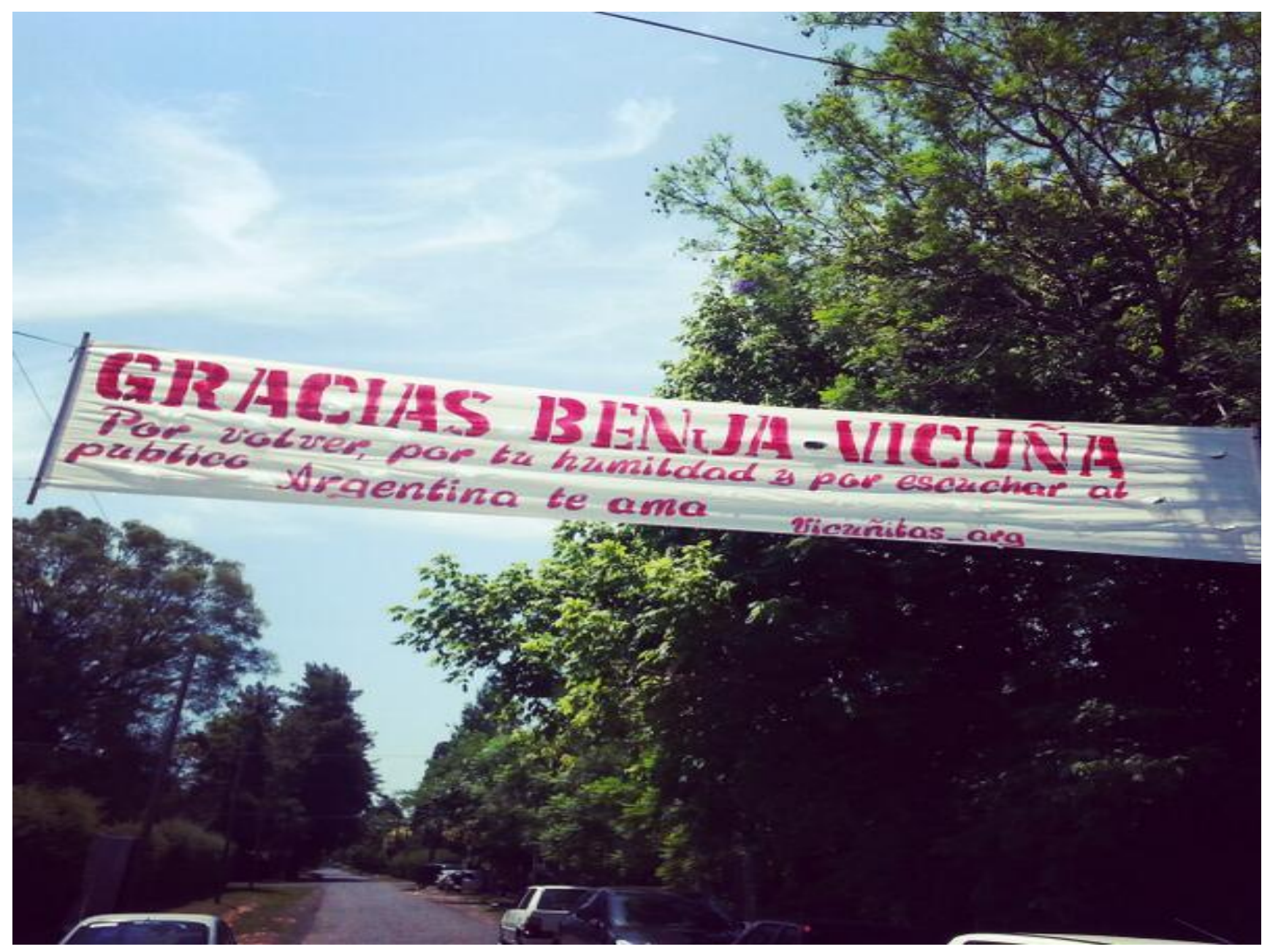

\footnotetext{
${ }^{3}$ En http://www.ratingcero.com/notas/112560-el-pasacalle-las-fanaticas-vicuna-su-vuelta-farsantes (Consultada: 22 diciembre 2013).
} 
La comunicación del actor y sus fans a través de su Twitter personal no se hizo esperar:

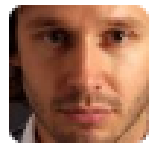

\section{Benjamín Vicuña Luco@benjavicunamori-19 de dic.}

"Yo sólo fui suavemente al otro lado del camino". Vuelvo por el cariño a mis compañeros y al público. \#FinaldeFarsantes

Abrir

El agradecimiento de los seguidores de la tira fue plasmado en una placa que le regalaron al actor. ${ }^{4}$

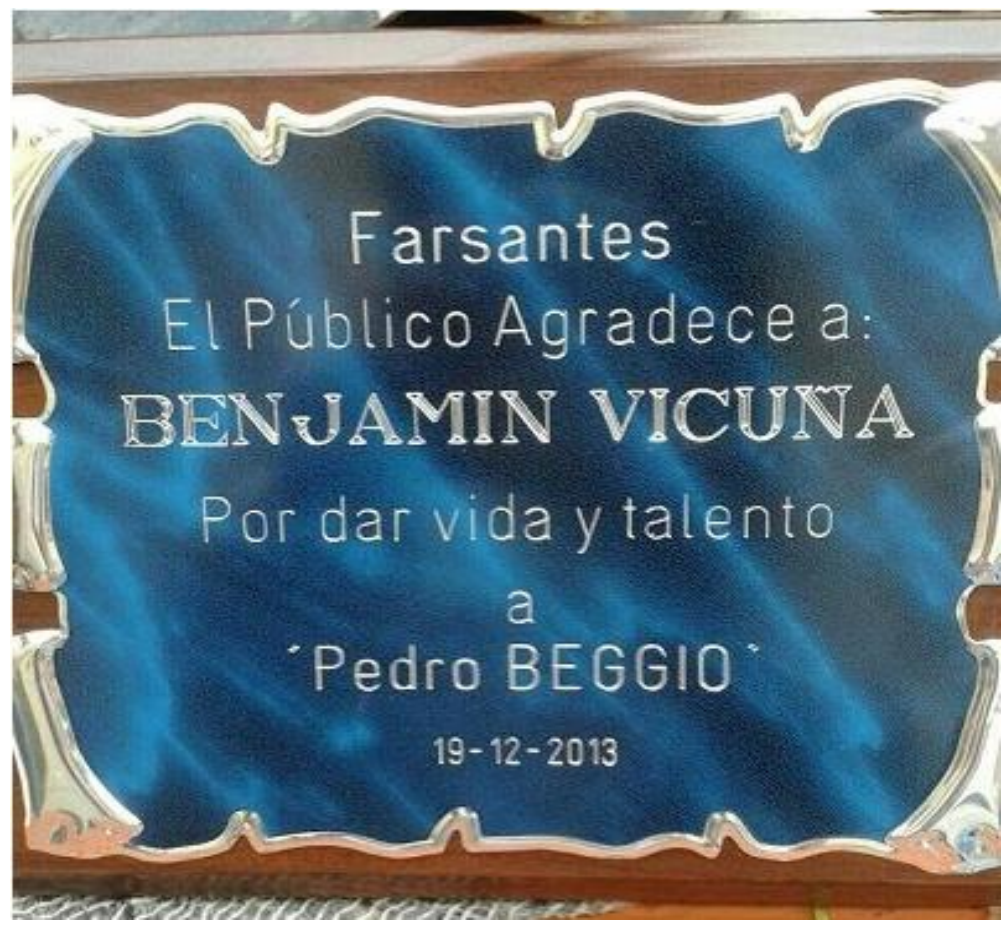

\footnotetext{
${ }^{4}$ En http://www.primiciasya.com/primicias/Fanaticos-de-Vicua-sorprendieron-al-actor-con-unaplaca-20131220-0029.html (Consultada: 27 diciembre 2013).
} 
El ejemplo citado permite observar el accionar de las audiencias, quienes utilizaron las redes sociales para convocar una marcha frente a la productora. Si bien la iniciativa se realizó a través de la redes, no fue así la acción concreta. Tanto la convocatoria como la protesta en sí, demostraron como puede convivir una dimensión analógica junto con una dimensión digital en las audiencias.

Notoriamente, las audiencias cambiaron, se desarrollaron con el paso del tiempo, adquirieron un rol más activo, creativo, productivo, sin embargo, esto no significa que perdieron su dimensión analógica, sino que dicha dimensión les permite configurarse actualmente como usuarios, inmersos en la era digital, pero que mantienen características anteriores. 


\section{$\mathcal{L} \mathcal{A} \mathcal{T} \mathcal{R} \mathcal{A}$}

El melodrama es un género que surgió como melodrama musical en el siglo XVI, pero que con el paso de los años fue transformándose hasta convertirse en su versión actual. En América Latina, las ficciones televisivas presentan una matriz melodramática, la cual trabaja con el imaginario colectivo, produciendo identificación, amor, odio, pero siempre interpelando a las audiencias. Es necesario hablar de matriz debido a que en la actualidad las tiras presentan una hibridación con las comedias, resultando difícil encontrar una ficción que presente puramente el género melodramático, pero si algunos tintes.

Antes de adentrarnos en las características actuales que presentan las tiras, es necesario hacer un revisionismo de cómo fue la aparición del melodrama. Considerando al folletín y las novelas semanales como instrumentos influyentes en el progreso del melodrama. Aunque difieren en su edición, se considera una variante de la novela, al publicarse en entregas sucesivas.

Desde sus comienzos, el melodrama estuvo asociado a las clases populares, identificado al género femenino. Criticado desde la cultura culta, por exacerbar historias desbordadas de placer, fantasías, deseos, que provocaban la exaltación en los espectadores teatrales, pero que al no proponerle tramas complejas, no les permitía desarrollar un pensamiento objetivo, crear una actitud crítica sobre lo que estaban mirando. 
Jesús Martín Barbero (1983) afirma la existencia del desprecio de algunos sectores de las élites consagrando el vergonzante sentido de la palabra melodrama y más aún del adjetivo melodramático, como sinónimo de todo lo que para el hombre culto caracteriza la vulgaridad de la estética popular, sentimentalismo.

Otras investigaciones como la de Beatriz Sarlo, denominada El Imperio de los sentimientos (1985), sobre las ficciones sentimentales de circulación periódica en el primer tercio de siglo del siglo XX; permiten vislumbrar que el melodrama era clasificado con términos peyorativos. Considerado una fantasía de escape, superficial, que no requería ningún conocimiento, estudios previos, para ser entendido.

En este contexto es necesario analizar los diferentes enunciados que surgieron en el momento de definir al melodrama:

Ła clave del entendimiento familiar de la realidad" (Monsiváis 1979: 84). Esta definición demuestra la imbricación de ficción y realidad. Como las fuertes emociones, apelación a los sentidos, conmoción que provoca el melodrama, producen un lugar de ensoñación tal que es llevado a la cotidianidad.

El drama del reconocimiento", según el Director de teatro y cine, Peter Brooks (1974). La posibilidad de identificarse con un personaje, de querer vivir las situaciones que atraviesa un actor, de verse reflejado en la manera de actuar o decir. Todas estas características crean un fuerte lazo entre las audiencias y el melodrama, que se reinventa constantemente.

El lugar donde autor, lector y personajes intercambian constantemente de posición" (Da Matta 1985: 96). En el melodrama nada es estático, todo está mezclado, todo cambia de ubicación, los personajes, las historias varían con el tiempo. Existe un contrato implícito entre el autor y el lector, donde el lector ya sabe lo que puede suceder dentro de ciertos 
límites marcado por el autor, y este juega con el lector, lo lleva a lugares lejanos, interpela sus emociones, pero siempre dentro de las lógicas del melodrama.

Coincidiendo con Jesús Martín Barbero, en el melodrama está todo revuelto, las estructuras sociales con las del sentimiento, mucho de lo que somos y de lo que soñamos ser, el robo de la identidad, la nostalgia y la rabia.

Un ejemplo característico del melodrama de los años setenta son las soap opera, termino estadounidense, con el que se define - a los melodramas domésticos articulados en conflictos familiares de la clase media, expuestos siempre desde una perspectiva femenina (las tribulaciones de una madre, de una enfermera, etc) y que son retransmitidos como serial en el programa de la tarde, destinados básicamente a las amas de casas (...) Poseen una discontinuidad producida con intervalos entre los tres y cinco minutos para dar paso a un paréntesis de publicidad comercial, de modo que tales seriales, con sus puntos y apartes (que no siempre corresponden al final de escena y fundido) deben ser escritos y rodados con una cadencia dramática y rítmica relativamente estandarizada, que admita tales cuñas publicitarias, generalmente tras una frase decisiva o un momento de tensión emocional, momento óptimos desde el punto de vista de la receptividad para proceder al bombardeo publicitario del telespectador" (Gubern 1974: 5).

Si bien el melodrama toma situaciones, personajes de la tragedia, lo hace de una forma menos dramática, alejándose de conjuros, maleficios, dioses, batallas, características del carácter sagrado de las tragedias clásicas.

El Doctor Román Gubern afirma que el melodrama es el hijo del drama, motivo por el cual adopta sus núcleos conflictivos, como la lucha entre el deber y la pasión, entre la lealtad y el amor, llevando al espectador a una identificación con la victima protagonista, que proyecta sus odios y afectos sobre el resto de los personajes. 
Cuando Gubern expresa que el melodrama muestra el triunfo de la virtud y el castigo del vicio, yo difiero con esta concepción. Aunque en un principio esta regla" se ejercía en todos los melodramas, con el paso de los años, la incorporación de la realidad a la trama, demuestran que no siempre triunfan los buenos" y pierden los -malos", como ocurrió en la tira argentina Amor en custodia ${ }^{5}$, donde algunos de los personajes malos se arrepienten de sus errores convirtiéndose en buenos, y otros logran escapar al exterior, para no ser juzgados por sus negocios en el tráfico de diamantes.

Coincido en que el melodrama es una degradación de la tragedia clásica, pero cada vez más los melodramas se alejan de las tragedias, creando sus propios códigos, en los que no hay, en muchos casos, vencedores ni vencidos, sino solamente personajes con conflictos, sensaciones y situaciones realistas. Si bien estas características estaban presentes en ficciones de décadas pasadas como Rosa de Lejos (1980) - cuyo personaje principal era una modesta costurera que pudo superarse y convertirse en una diseñadora prestigiosa a nivel internacional- en la actualidad, las tiras en su mayoría, presentan un tinte mas costumbrista.

La matriz melodramática contemporánea se plasma en la vida real de la gente, lo que demuestra que la ficción tiene su raíz en los temas sentimentales cotidianos. Perdida de empleo, problemas económicos son algunos de las temáticas actuales que son retomadas por el melodrama, y esta situación provoca que las audiencias se sientan identificadas con lo que están mirando, que su día a día, experiencia vivida se vea reflejada en la pantalla. Un

\footnotetext{
${ }^{5}$ Tira argentina, producida por L.C. Acción Producciones (Enrique Estevanez). Comenzó a emitirse el martes 1 de marzo de 2005 y finalizó el miércoles 28 de diciembre de 2005. Horario: 13.30hs. Canal Telefe. Protagonistas: Osvaldo Laport, Soledad Silveyra, Sebastián Estevanez, Claudia Fontan, Carolina Papaleo y Melina Petriella. Guionistas: Marcela Citterio y Enrique Estevanez. Directores: Carlos Luna, Pablo Ambrosini y Daniel de Ciancio. El argumento se centra en la vida de Paz Achaval Urien, una poderosa empresaria, que a raíz de un intento de secuestro, conoce a Juan Manuel Aguirre, un hombre de campo, quien le salva la vida. Dicha situación hace que Paz contrate a Juan Manuel como su guardaespaldas. El día a día juntos, y las diversas situaciones que deben atravesar, hace que se enamoren. Sin embargo, las familias que tiene cada uno de ellos, se convierten en uno de los principales obstáculos para decidirse a comenzar una relación.
} 
ejemplo es la tira Mujeres de $\mathrm{Nadie}^{6}$, en donde algunos personajes sufrían violencia de género, problemas económicos, pérdida de empleo.

Aunque lentamente se prescinda del melodrama caracterizado por la empleada doméstica que se enamora de su jefe, o del rico que ama al pobre, surgen estas historias realistas, como Contra las Cuerdas ${ }^{7}$ que no dejan de permitir ser un lugar de ensoñación, de escape a la rutina, sino que además utilizan herramientas más cercanas a la cotidianidad, mostrando personajes preocupados por conseguir trabajo, por mantener a su familia.

Definitivamente, la matriz melodramática permite consolidar un lugar de encuentro entre la narración y las audiencias. Es masivo y popular porque las audiencias encuentran en él una mezcla de sentimientos, reconocimiento, identificación, es decir que se encuentran interpeladas constantemente. Lo rechazan, pero lo vuelven a elegir, es una suerte de amor odio, donde tanto las audiencias como el autor conocen las reglas del juego, y aceptan jugarlo, dando rienda suelta a la imaginación.

\footnotetext{
${ }^{6}$ Tira argentina, producida por Pol - Ka Producciones (Adrian Suar y Fernando Blanco). La primera temporada comenzó a emitirse el jueves 10 de mayo de 2007, finalizando el 12 de diciembre de 2007. Horario: 14hs. Canal El Trece Tv. Protagonistas: Susu Pecoraro, Luis Luque, Claribel Medina, Federico Olivera, Agustina Cherri, Alejandro Awada y María Leal. Guionistas: Marcos Carnevale, Ernesto Korovsky y Sebastián Parrota. Directores: Víctor Stella y Alejandro Ibañez. El argumento se centra en la vida de cuatro enfermeras que trabajan en el mismo hospital público, y deben atravesar diversas historias personales que se involucran con el trabajo de cada una.

${ }^{7}$ Tira argentina, producida por On Tv (Bernarda Llorente y Claudio Villarruel). Comenzó a emitirse el lunes 30 de noviembre de 2010 y finalizó el 14 de abril de 2011, en el prime time de La Tv Pública. Protagonistas: Rodrigo de la Serna, Soledad Fandiño, Maximiliano Ghione y Roberto Carnaghi. Guionista: Juan Pablo Domenech, las líneas narrativas pertenecen a Santiago Mitre, Alejandro Fadel y Martín Mauregui. Director integral: Alejandro Maci. El argumento narra la vida de un boxeador amateur, quien debe huir de su pueblo natal (Chajarí - Entre Rios) cuando se niega a perder una pelea a cambio de dinero. Una vez instalado en el Conurbano de la Provincia Buenos Aires, busca a su hermano para que lo ayude a conseguir empleo, y de esta manera poder enviarle dinero a su esposa e hijos que quedaron en el pueblo. La historia cambia cuando conoce a una mujer de la que se enamora, formando un triangulo amoroso junto a su hermano. La tira se desarrolla íntegramente en un barrio del Conurbano Bonaerense.
} 


\section{MELODRAMA / TEATRO - FOLLETÍN - RADIOTEATRO}

El melodrama es el hijo de la Revolución Francesa: de la transformación de la canalla, del populacho en pueblo, y de su escenografía. Es la entrada del pueblo en la escena, es su doble sentido. Las pasiones políticas y las terribles escenas vividas han exaltado la imaginación y la sensibilidad del pueblo que al fin puede darse el gusto de poner en escena sus emociones, sus fuertes emociones (...) El melodrama/teatro de $1800-1820$ es el primer gran espectáculo fabricado industrialmente para el consumo de masas" (Barbero, 1983: 70).

A mediados del siglo XIX, aparece el folletín y novelas por entregas en Argentina. Las primeras manifestaciones populares, de la hoy conocida cultura de masas, se originan en ese periodo de tiempo, donde se producen, distribuyen y consumen narraciones semanales, denominadas folletín, creando una influencia en el campo literario.

Son las conocidas historias del corazón de tipo folletinesco, publicadas como cuentos de amor o en formato de novelas en serie, por episodios o capítulos. El amor, la pasión, el deseo y la felicidad eran la base primordial de todas las narraciones, por eso se conocían como literatura sentimental.

Beatriz Sarlo (1985) explica que el éxito de las narraciones semanales tiene que ver con las necesidades a las que responden los productos de una cultura consumida por sectores medios y populares. Estas narraciones proporcionaba a sus lectores placer por su fluir ininterrumpido. Eran fáciles, rápidas y legibles, es decir que se trataba de literatura seriada, producida muy velozmente. Como los lectores cultos, las clases populares también buscaban en la literatura ese lugar de ensoñación, evasión y aventura. 
En Argentina, a finales del siglo XIX y en el transcurso de las primeras décadas del siglo XX, se alzaba el apogeo de la literatura sentimental, en formato de folletines que se vendían en kioscos o puerta a puerta, y que eran esperados con ansias todas las semanas por el sexo femenino, debido a que fueron considerados como la literatura de las mujeres. Era común que un grupo de amigas, vecinas, familiares se reúnan en una casa para introducirse en la lectura. Compartiendo de esta manera, fantasías, sueños, que les permitía escaparse de lo cotidiano e identificarse con los personajes y sus dificultades.

Las clases cultas miraban con desprecio el fenómeno de ciertos folletines que presentaban tintes melodramáticos. Consideraban que el nuevo público medio o popular que había surgido, estaba poco entrenado para desarrollar un pensamiento crítico sobre los textos que leían porque carecían de estudios previos, recursos intelectuales necesarios para fundamentar sus opiniones.

Afirmar que el melodrama es el género más querido de las clases populares presupone que las clases altas lo miran con desprecio, de una manera banal. Aunque, esto ocurrió con el surgimiento de los folletines, también las clases altas tenían curiosidad sobre ese fenómeno, que en varias ocasiones eran consumidos a escondidas, pero que lograba la identificación de historias, personajes, no solo de las clases populares sino también de la clase alta.

Se puede mencionar un pasaje, en el siglo XX, el del folletín al radioteatro. La radio se constituyó como el medio más popular. Características como el bajo costo de emisión y recepción, y fundamentalmente, la llegada a zonas alejadas, hicieron que la radio fuera el medio más utilizado en Latinoamérica. 
En simultáneo con Estados Unidos, Argentina fue el país que inició las transmisiones regulares de radio. A partir del año 1920, con la transmisión de la ópera Parsifal, dirigida por Félix Weingarten desde el Tearo Coliseo, en el país comenzaron a difundirse eventos deportivos, musicales. Sin embargo, la creación del radioteatro marcó una etapa sin precedentes dentro de la radiofonía argentina.

El investigador Luis Sandoval (2003) afirma que el radioteatro, también llamado radionovela, se encuentra en la intersección de dos preferencias de la cultura popular: la radio y el melodrama. En un contexto mediado por la comercialización de la radiofonía, Argentina constituye al respecto un caso pionero. Esto se debe por un lado a la avanzada técnica radiofónica nacional en los inicios de la "telefonía sin hilos". Como se recuerda Argentina es el país en donde se realiza la primera emisión musical y también la primera en incorporar avisos comerciales. Por otra parte, en nuestro país se asienta una sólida tradición de teatro popular.

Los primeros radioteatros fueron una mezcla de breves relatos, dramatizaciones y canciones folklóricas. Con el paso de los años, se constituyó el radioteatro seriado con predominio del melodrama. Con la premisa de atraer a diferentes públicos, se produjeron radioteatros infantiles, policiales, históricos, comedias familiares, gauchescos, y románticos.

El éxito de los radioteatros radica no solo en la teatralización misma, sino también en el merchandising que lo acompaña, como por ejemplo álbumes fotográficos de los actores y actrices, los libretos, la composición musical, entre otras cosas, eran vendidos en los comercios. Además, era común, la realización de giras de la compañía para la difusión de los radioteatros, durante los fines de semana en localidades vecinas. 
Los oyentes esperaban fervientes al elenco que conformaba el radioteatro que escuchaba a través de la radio. Esa versión teatralizada de la radionovela que realizaban provocaba alegría, pasión entre sus seguidores, que al final de la jornada, realizaban fiestas para celebrar la llegada del radioteatro al pueblo.

El radioteatro tuvo su mayor auge durante las décadas de 1930 y 1970 . Luego, con el crecimiento de la televisión y la creación de la frecuencia modulada (FM), las radionovelas perdieron popularidad, y fueron produciéndose en menor medida. En la actualidad, son minoría las radios que producen radioteatros. Se puede mencionar a Radio Nacional que tiene un ciclo llamado Las dos carátulas, que presenta todos los domingos diferentes radioteatros. 


\section{TELENOVELA}

El surgimiento de las telenovelas en América Latina se remonta al nacimiento de la televisión, durante la década del cincuenta. Es el modelo más fiel del melodrama, en el cual se exponen las emociones, fantasías y pasiones.

Nora Mazziotti (1995) expresa que la telenovela es uno de los géneros fundacionales de la televisión argentina. Tributaria del radioteatro, de la que asimiló la circulación de actores, libretos y autores, así como el género melodramático y el folletín por entregas, de su simbiosis surgió un estilo propio y claramente distintivo en relación con sus similares latinoamericanas.

La telenovela es un género que narra una historia en la que aparecen diferentes obstáculos que los personajes van superando en el transcurso de los capítulos. Es una historia donde existen imposibles y distintas problemáticas como clases sociales, lazos de sangre, desgracias, distancias, entre otras. Destacándose en Argentina la presencia de un amor dificultoso entre la pareja protagónica.

Las telenovelas irrumpen en el sueño de diversos sectores de la sociedad, provocando risas, llantos hacía una historia o personaje en particular. Del mismo modo, permitieron idolatrar a una actriz y/o actor por su interpretación, sus modismos, vestimenta, entre otros. 
Los Doctores en Ciencias Sociales, Gustavo Aprea y Marita Soto realizaron un estudio sobre la historia de la telenovela argentina, denominado Telenovela, telecomedia y estilo de época. El sistema de géneros narrativos en la Argentina hoy ${ }^{8}$; a través de este estudio, los autores clasifican la telenovela del siguiente modo:

- Telenovela clásica, ligada a la tradición melodramática de desarrollo narrativo lento y lineal, excesivamente exagerada y esquemática tanto en términos de la construcción de los personajes como en la ambientación, típico ejemplo de verosímil genérico;

-Telenovela moderna, más cercana al drama realista sin llegar a la tragedia que incorpora a sus historias menciones o citas de conflictos y acontecimientos sociales, típico ejemplo de verosímil social;

-Telenovela posmoderna o neobarroca, que se distingue por la yuxtaposición de rasgos propios del género con otros ajenos que hacen difícil su reconocimiento como telenovela y se asimila más al serial televisivo norteamericano, con personajes que no se inscriben claramente en la dicotomía bueno/malo, y con formas de exhibición del sufrimiento de las heroínas que adquiere caracteres radicales o se alejan totalmente de la matriz genérica al asumir rasgos propios del género aventuras y/o de la telecomedia.

La matriz melodramática no aparece sola. Con el paso de los años se relacionó con otros géneros como el suspenso, el policial y también la comedia. La telenovela posee la característica de poder mezclar, acumular los diferentes géneros y formatos, debido a que los géneros puros no existen, sino que hibridan.

\footnotetext{
${ }^{8}$ En

http://www.google.com.ar/url?url=http://www.eca.usp.br/associa/alaic/Congreso1999/16gt/Gusta vo\%2520Aprea.rtf\&rct=i\&frm=1\&q=\&esrc=s\&sa=U\&ei=fLOZU4i6D6LMsQS1ioFw\&ved=0CBIQFiAA\&s ig2=gwQAV27DtuGDyJnaTBFrKg\&usg=AFQjCNEF-Awv3YvX0xVQGKcj1TAQTT3fhw (Consultada: 5 enero 2013).
} 
Entre la lógica del sistema productivo y la lógica de los usos median los géneros. Son sus reglas las que básicamente configuran los formatos y es en ellos donde ancla el reconocimiento cultural de los grupos (...) El género es ante todo una estrategia de comunicabilidad, y es como marcas de esa comunicabilidad que un género se hace presente y analizable en el texto (...) El género es clave para el análisis de los textos masivos y, en especial, de los televisivos" (Barbero 1987: 309).

Siguiendo la idea de Jesús Martín Barbero, la audiencia tiene las herramientas para saber en determinados momentos y ficciones, cuándo un texto/relato ha sido interrumpido, conocer las formas posibles de completarlo, de resumirlo, de ponerle un título y de compararlo.

En diversos países latinoamericanos, la ficción que se emite todos los días se la denomina de diferentes formas, como culebrón, telenovela. En Argentina dicho tipo de ficción se la denomina tira.

Ła tira designa la producción de un capítulo de programa de emisión diaria. Es un término comodín, que se refiere a una instancia industrial, de producción y de frecuencia de emisión, equiparable al de la serie. Puede aplicarse tanto a una comedia o a una telenovela, para jóvenes o para adultos, mientras se emitan diariamente" (Mazziotti 2006: 28). A las ficciones de la tarde no se las nombra como tiras, sino telenovelas. Se denomina tira a las ficciones de la noche, cuando hibridan lo cómico con lo sentimental.

La palabra tira provoca una homogeneización de los géneros en los programas de televisión, haciendo desaparecer los límites y las fronteras entre ellos, es decir que la tira presenta ciertas licencias como la posibilidad de aunar diferentes géneros, crear múltiples situaciones, las cuales son permitidas por las audiencias.

Sostengo que la tira es más que un género, es un espacio de encuentro, de reflexión, de sentimientos yuxtapuestos, de sentidos encontrados, de identificación, de ensoñación que 
trasciende la pantalla, generando vínculos, posibilitando debates, resignificaciones constantes.

Son numerosas las acciones que se desprenden de una tira, algunas mas consientes que otras, pero que están, que emergen constantemente no solo en el momento de mirar una tira determinada, sino en el antes y en el después de la realizar ese proceso.

El éxito de las tiras argentinas, no solo radica en este país sino en su venta al exterior, ya sea en mercados latinoamericanos como europeos y asiáticos. En algunos casos, se compra la tata", es decir, la telenovela completa para ser transmitida en el país receptor, y en otros casos se compra el formato (la idea original, los libretos, asesoramiento) y cada país la produce con sus actores, directores y guionistas, como por ejemplo en los últimos años Los exitosos Pells (Underground Contenidos y Endemol Argentina, 2008) se emitió como Los exitosos Pérez en México, Los exitosos Gómez en Perú, etc.

La expansión de Internet, sin duda, produjo un cambio en el momento de mirar una tira. No es necesario conversar con amigos, familiares sobre una tira en particular, sino que se abrieron distintos sitios, foros desde las productoras y también desde las audiencias, para debatir, intercambiar opiniones sobre una misma tira.

Los foristas de diversos países dialogan sobre los capítulos, intercambian información, suben noticias periodísticas sobre los actores, hasta escriben críticas sobre el desarrollo de la trama.

La evolución y los cambios que sufrieron las tiras permiten pensar en la reformulación constante de las mismas, estudiando audiencias que se vuelven más reflexivas, competentes y productivas (Longo Elía, 1999).

Tal es el caso de la tira Resistiré (Telefe, 2003) en la que se abordó el tema del tráfico de órganos. En Montecristo (Telefe, 2006) se trabajó sobre la apropiación de bebes durante 
la última dictadura militar en Argentina. También, en Vidas Robadas (Telefe, 2008), cuya trama ahondaba en la trata de personas.

En algunos casos, las tiras, más allá del contexto social /político / cultural en el que se transmiten, aunque sorteen diferentes obstáculos como idiomas, culturas, trascienden a pesar de todo. Existe una audiencia que las espera, las disfruta, las critica, pero que sin duda, las consume al construir imaginarios colectivos desde las cuales las audiencias se reconocen como tales. Un ejemplo es Muñeca Brava (Telefe, 1998) que fue vendida a países como Israel.

La globalización de los productos televisivos junto a la segmentación de las audiencias, hacen que no se pueda pensar en ellas como un todo homogéneo, con características fijas que se repitan constantemente. Por este motivo, el poder que tienen las tiras de trascender con éxito a pesar de estos obstáculos es digno de destacar.

El misterio del éxito de las tiras, de la permanencia, de la vigencia, de la elección permanente por parte de las audiencias hace que se constituya como uno de los géneros más importantes que tiene la televisión.

El poder mirar una ficción varios días a la semana, en familia, con amigos, solos, comentarla al día siguiente, identificarse con un personaje, con una situación en particular, hacen que las tiras pasen a formar parte del cotidiano de la gente. 


\section{REDES}

\section{SOCIALES}

CAPITULO II 
En el capitulo se analizarán cómo las sociedades contemporáneas están siendo mediadas por la tecnología, desde la perspectiva teórica de Sociedad Red propuesta por Manuel Castells, produciendo un paralelismo entre ambas sociedades.

La clasificación de diferentes tipos de redes sociales hasta llegar a estudiar los orígenes de Facebook, la red que rige la presente investigación, será interesante para analizar cómo surgió, en qué contexto, cómo se fue desarrollando hasta convertirse en un nuevo medio, coexistiendo con medios de comunicación tradicionales.

En este sentido, se exponen diferentes conceptualizaciones sobre las redes sociales, considerándola como un nuevo medio de comunicación y de información. Los resultados de diversos estudios cualitativos serán útiles para comprender el auge de Facebook en Latinoamérica, focalizándome en Argentina.

Con el presente eje temático pretendo demostrar los diferentes usos que pueden tener las redes sociales. Centrándome en algunos Facebooks oficiales de ficciones televisivas para comprender el funcionamiento de los mismos combinados con la utilización de otras herramientas digitales que posibilita la tecnología. 


\section{INTTRODUCCIÓN}

El siglo XXI está caracterizado por ser una época marcada por los cambios tecnológicos a pasos agigantados. Internet, pionera en el mundo siendo un conjunto de redes de comunicación interconectadas, permite no solo la posibilidad de estar conectado con una persona de otro país sino que concentra los viejos medios hoy digitalizados, como la radio y la televisión y los nuevos medios, nacidos de la propia Internet, como los blogs, el correo electrónico, las redes sociales, entre otros.

A modo de un instrumento para la transmisión rápida de información, Internet se consolida permanentemente, permitiendo ser considerada según el Doctor en Sociología Manuel Castells (2000) como el tejido de nuestras vidas. No es futuro, es presente, es un medio para todo, que interactúa con el conjunto de la sociedad. Es más que una tecnología, es un medio de comunicación, de interacción y de organización social. Las proyecciones sobre el número de usuarios de Internet en los próximos años alcanzan cifras impresionantes. Es decir, se trata de un fenómeno que crece a un ritmo vertiginoso y cuyos efectos son parte de la historia presente.

Castells (2009) plantea que desde los inicios de la humanidad existe una necesidad básica de convivencia e interacción, que durante el desarrollo de los medios de comunicación junto con la tecnología, esta necesidad logra canalizarse por la capacidad de interacción, información y participación que ofrecen las plataformas de Internet.

Internet permite un modo de comunicación que surge a partir del desarrollo de las tecnologías digitales, esto significa que estamos ante una comunicación en red, es decir, multimedial e interactiva. Internet es un medio nuevo e innovador, que abarca los contenidos de los medios tradicionales. Esto significa que los medios como la televisión, la radio, convergen con Internet, y gracias al avance de las tecnologías digitales, la audiencia 
puede elegir cómo ver una tira determinada, de una forma tradicional a través del televisor o directamente desde Internet.

Un caso es la tira Guapas $^{9}$ que puede ser vista no solamente por televisión, de lunes a jueves a las 21 hs en EL Trece Tv, sino que también en la web oficial.

El canal que la transmite sube al día siguiente de la emisión, cada capítulo, a través de la siguiente página web:

http://www.eltrecetv.com.ar/guapas-0

Los comentarios de la audiencia sobre cada capítulo no se hacen esperar mientras que los episodios son vistos por 100.000 personas en promedio. Dichos comentarios se centran en mostrar su contento o disconformidad por una escena en particular, elogios hacia un actor, actriz o pareja en particular, diversos pedidos, como por ejemplo más escenas entre una pareja de ficción, consultas sobre la musicalización de la tira, entre otras.

\footnotetext{
${ }^{9}$ Tira argentina, producida por Pol - Ka Producciones (Adrian Suar y Fernando Blanco). Comenzó a emitirse el lunes 17 de marzo de 2014 finalizando el viernes 9 de enero de 2015, en el prime time de El Trece Tv. Protagonistas: Mercedes Morán, Carla Peterson, Florencia Bertotti, Isabel Macedo, Araceli González, Dady Brieva y Mike Amigorena. Guionistas: Leandro Calderone y Carolina Aguirre. Directores: Daniel Barone y Lucas Gil. El argumento se centra en la vida de cinco mujeres que se conocen durante una protesta frente al banco que tenía sus ahorros y que cerró repentinamente, sin devolverles el dinero. Este hecho en particular provoca un giro en sus respectivas vidas, cuando sus sueños y proyectos se ven truncados. Siete años después, las cinco mujeres se hicieron amigas, y continúan luchando por lograr una estabilidad económica y afectiva.
} 


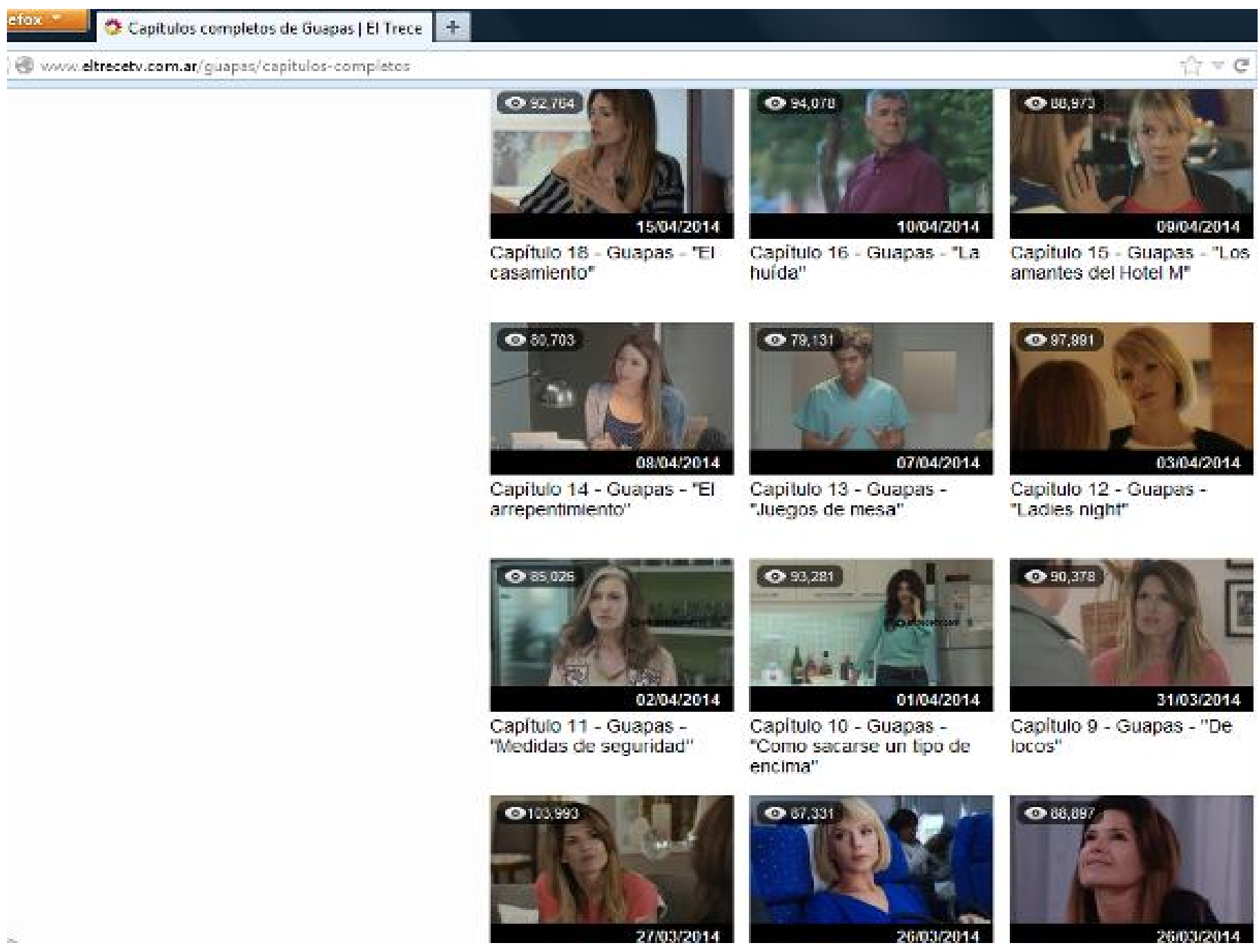

Imagen de la Web oficial de Guapas con los capítulos completos (Mayo 2014) 
La tira también se puede ver por Youtube, debido a que diversos usuarios suben diariamente los capítulos. Tal es el caso del usuario FlorBoing2" que creó la siguiente cuenta en Youtube:

https://www.youtube.com/playlist?list=PLvlscib1bPHfdvKupea5J86IOz7PJAv88

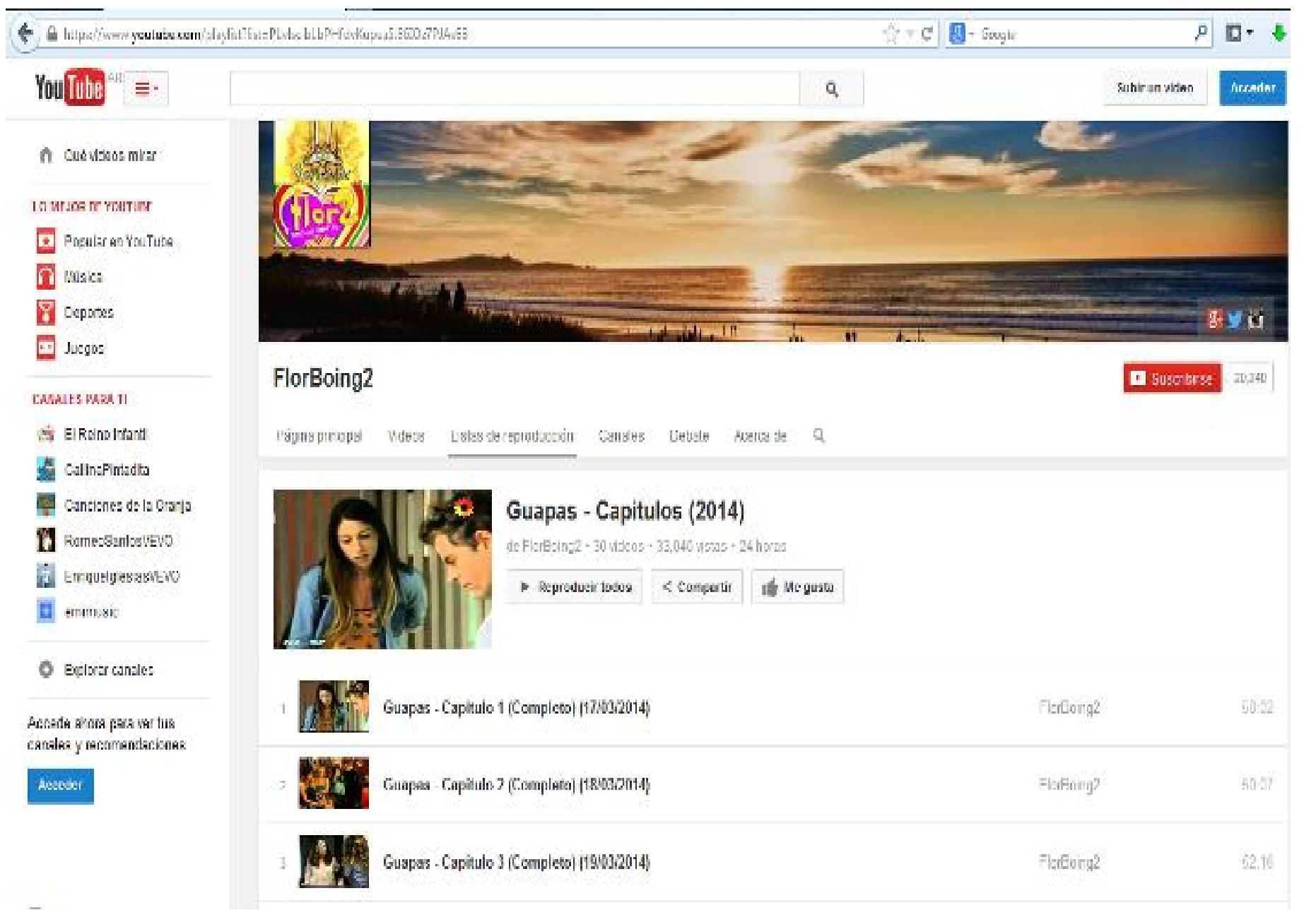


Internet es un mundo que se renueva constantemente, y que jamás deja de sorprendernos. Todos los días, se publican, se encuentran sitios nuevos que nos llevan a conocer a otros, y así sucesivamente. Es decir, que es una red, en la cual nos adentramos sin saber a dónde vamos a llegar. No solo por la información que se va a obtener sino por las múltiples relaciones que se pueden establecer a través de las llamadas redes sociales.

A pesar de los cambios productivos que posibilitó el advenimiento de la tecnología, como la interconexión, acceso inmediato a la información, participación activa de los usuarios, no debemos dejarnos deslumbrar por estas características, sino que es necesario ahondar profundamente en las continuidades y rupturas que conlleva este proceso.

La globalización construyó un escenario propicio para el desarrollo tecnológico, aparejado por un impulso de la economía que significó el crecimiento de los mercados financieros, comerciales y el mundo de las telecomunicaciones.

El neoliberalismo permitió la consolidación del mercado por sobre lo social y cultural, durante los procesos de fortalecimiento de las tecnologías de la comunicación. La sucesión de alianzas poderosas entre multinacionales e industrias digitales ponen en peligro la pluralidad en los medios de comunicación.

Con la aparición de Internet, los medios de comunicación aumentaron su exposición, dejando vislumbrar diversas presiones ideológicas y económicas. Todo medio es un negocio que responde a intereses políticos y económicos, por lo cual no puede desprenderse de este condicionamiento. En el mundo del periodismo, Internet fue contemplado como una herramienta poderosa para transmitir información. Con la intención de tener la primicia, la nota, antes que otros medios, los portales de noticias contribuyeron a publicar una información sin fuentes, sin un previo chequeo, carentes de un contexto, que en algunos casos en vez de informar desinforman, contribuyendo de esta manera al sensacionalismo. 
Por otra parte, la posibilidad de acceso permanente a Internet, con un bajo costo económico, y la distribución inmediata y masiva de la información, potencia la publicación de contenidos pornográficos, obscenos, violentos, racistas; que en determinadas situaciones violan la privacidad como el caso de famosas argentinas, que sufrieron la publicación de videos o fotos intimas, que las muestran teniendo relaciones sexuales, como la actriz Florencia Peña.

Además, el uso indebido de imágenes de modelos relacionándolas con la prostitución vip, como la modelo Jésica Cirio. Si bien sitios como Google fueron llevados a juicio por estos hechos, debiendo indemnizar económicamente a la víctima, el daño que sufrieron las personalidades expuestas es irreparable. Aunque el material fue sacado de los portales, es imposible identificar quienes bajaron las fotos o videos, y disponen de estos en sus computadoras personales.

También se puede mencionar la pornografía infantil. El hecho de poder comunicarse, escondiéndose a través de una identidad falsa, creando un vínculo, y un paulatino acercamiento con un menor a través de redes sociales o de webs específicas para conocer gente. Todo este marco que brinda Internet, posibilita el desarrollo de la pornografía infantil.

Del mismo modo, el mundo de la política no es ajeno al uso de los medios digitales. Diversos funcionarios públicos utilizan las redes sociales para expresar sus ideas, opiniones, informar actos, y fundamentalmente para crear un vínculo más cercano con la sociedad. Asimismo, Internet es un ámbito propicio para las discusiones entre los políticos.

La Presidenta de la República Argentina, Cristina Fernández de Kirchner, dispone de un Twitter y Facebook oficial que utiliza para compartir información sobre su gestión, difundir noticias, subir fotos/videos de los actos que oficializa. La cuenta de Twitter: https://witter.com/CFKArgentina fue abierta en abril del año 2010, durante su primera presidencia. La cuenta de twitter presenta 2.688 .488 seguidores (Consultada: Mayo de 2014). 


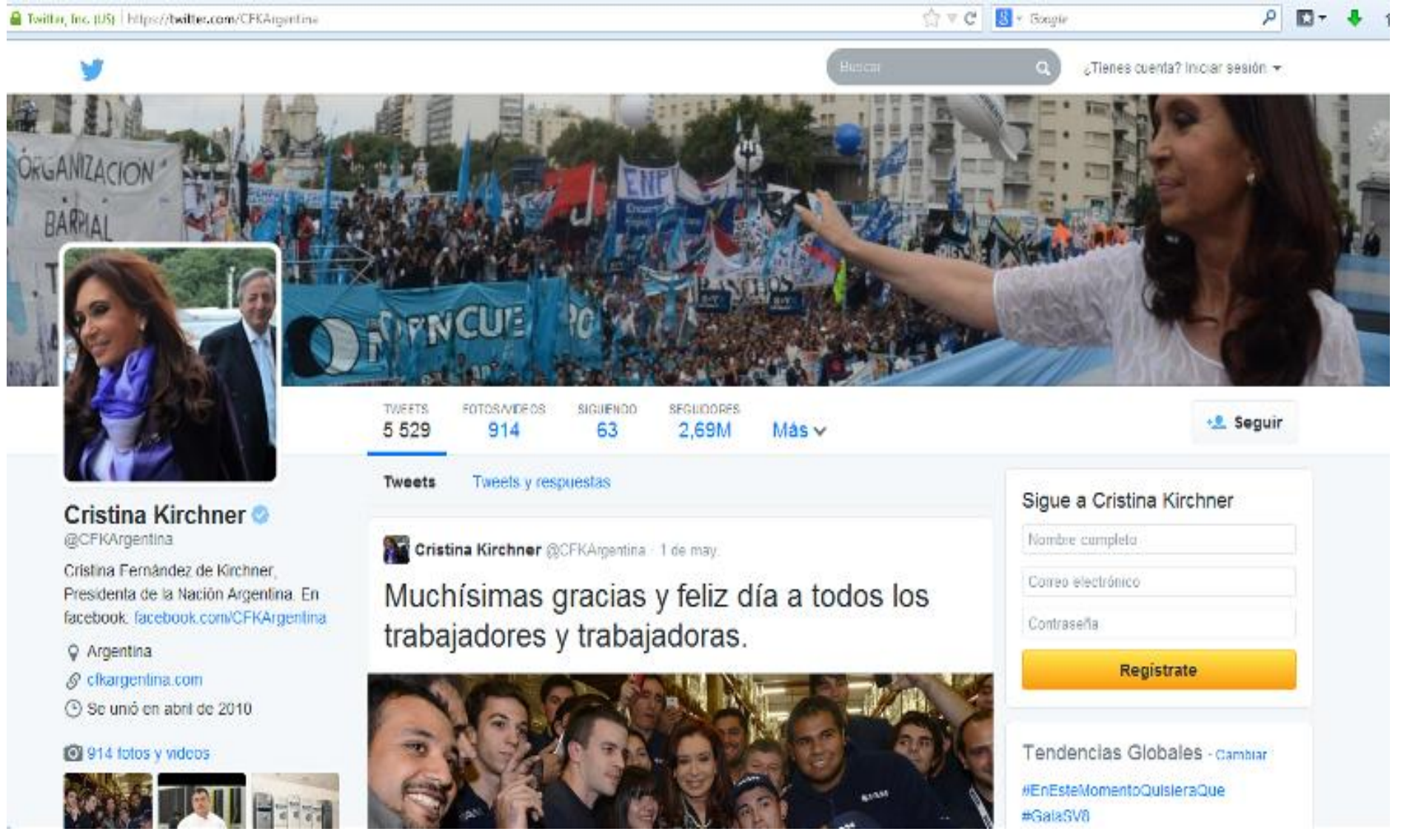

Imagen del Twitter oficial de Cristina Fernández Kirchner (Mayo 2014)

La imagen del encabezado muestra a Cristina Fernández de Kirchner en un acto público, saludando a la gente que la fue a ver con las banderas de diversas agrupaciones. Mientras que en su foto de perfil se visualiza la cara de ella y detrás al ex presidente Néstor Kirchner observándola. 
En uno de sus twetts se puede observar una foto de la Presidenta junto a los trabajadores de la fábrica de electrodomésticos Siam, icono de la industria nacional, en la reapertura de la planta en Avellaneda. Dicha fotografía es acompañada por un saludo en el Día Internacional de los Trabajadores.

Ayer, después de presentar la renovación total del FFCC San Martin. cfkargentina com/renovacion-tot.

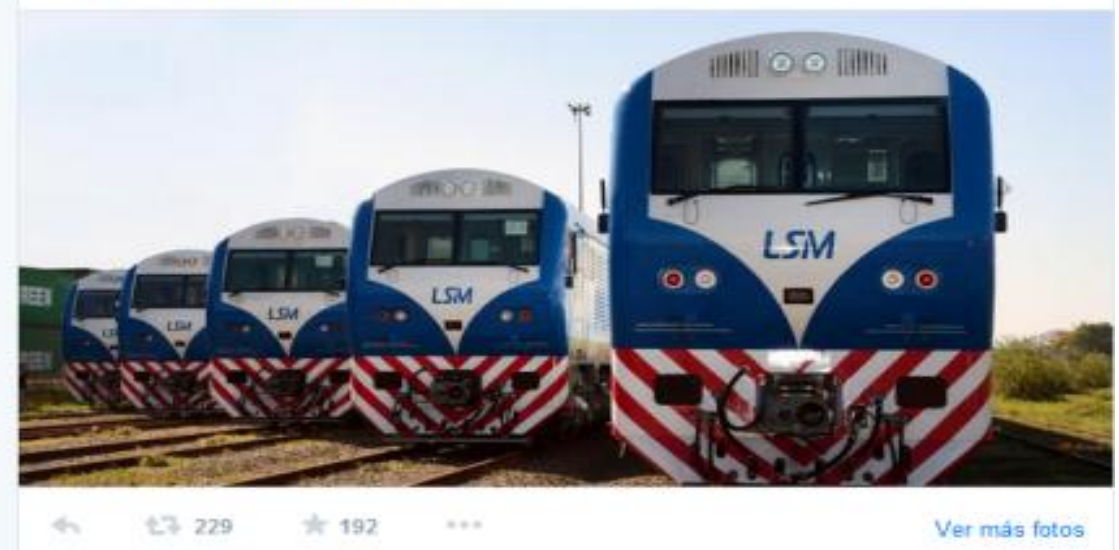


Otro Twett de la Presidenta se refiere a la presentación de los nuevos trenes del ferrocarril San Martín, junto con un sarcasmo sobre la ausencia de la noticia en algunos diarios.

La Presidenta de la República Argentina también dispone de un Facebook oficial: https://www.facebook.com/CFKArgentina, que utiliza para publicar información, anuncias actos oficiales, pero que además dispone de una cronología de su vida, con los acontecimientos personales y profesionales relevantes desde su nacimiento.

La foto de portada la muestra en un lugar ajeno al mundo de la política, formando parte de un espacio hogareño, relajado, junto a su perro, rodeada de plantas. Por su parte, mantiene la misma foto de perfil que en su twitter.

Tanto el Facebook como el Twitter oficial contienen un link que vincula directamente a la web oficial de la Presidenta: http://www.cfkargentina.com/. 


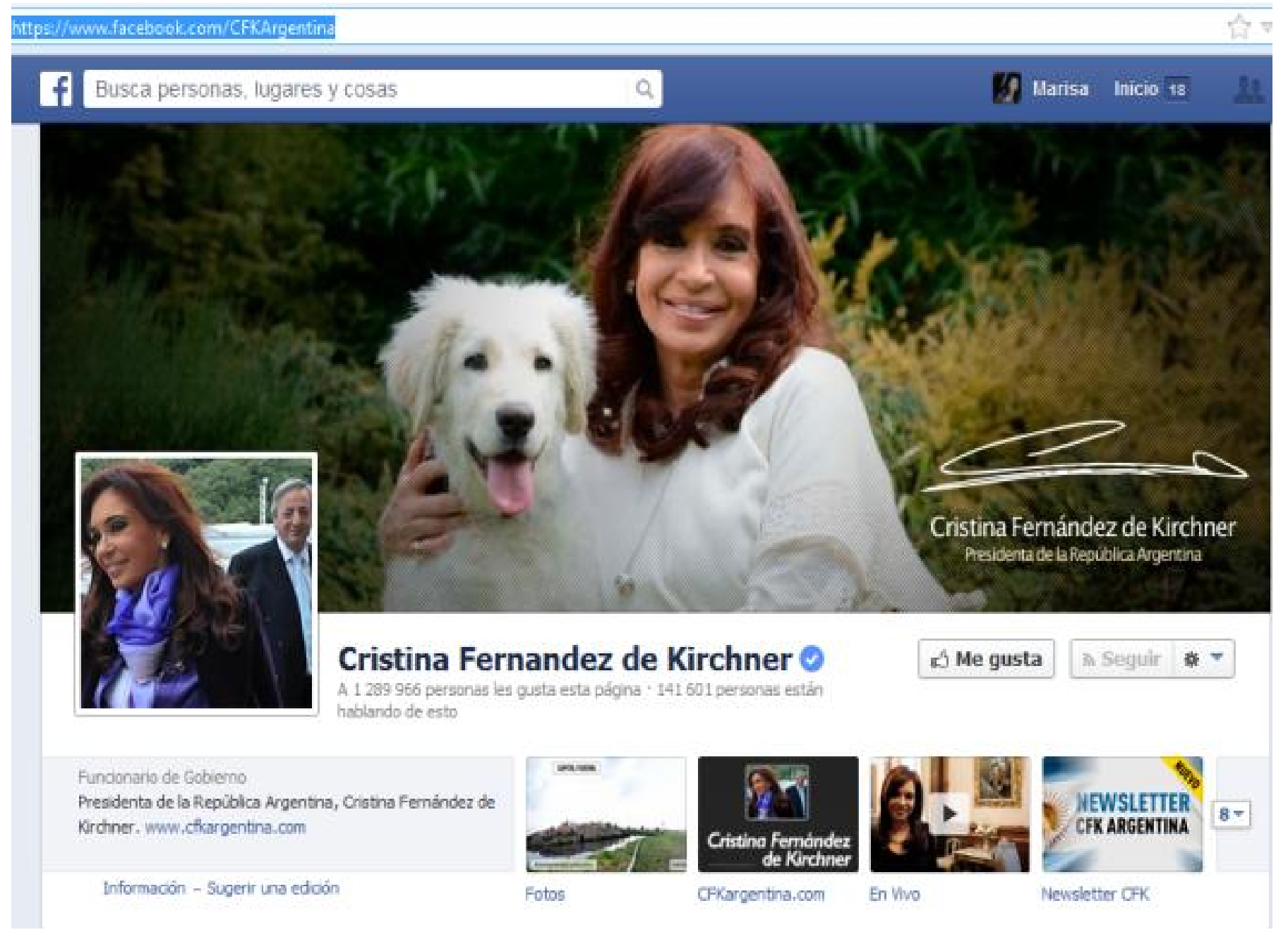

Imagen del Facebook oficial de Cristina Fernández Kirchner (Mayo 2014) 
Dentro del mundo de la política, Twitter y Facebook son utilizados como herramientas de marketing político. Coincido con la investigadora Ana Slimovich (2012), al afirmar que con la expansión de la red y la inserción de las instituciones políticas, sus actores y discursos a través de Internet, se produce la digitalización del espacio público, que se caracteriza por nudos discursivos donde lo político, lo informativo y lo publicitario aparecen entremezclados.

Por lo tanto, son los políticos quienes producen el escenario para conducir el diálogo. Cualquier intervención que produzcan dentro de las redes sociales generan un debate, discusiones, es decir, nuevas formas de la comunicación política, que trascienden lo digital y se expanden por diferentes medios de comunicación.

El uso de las redes sociales dentro de la política, no solo pertenece a funcionarios públicos, sino que también son utilizadas por diversos movimientos sociales, debido que las tecnologías permite acceder a un intercambio instantáneo y global.

En diferentes regiones de Chile, durante el año 2011, se sucedieron múltiples manifestaciones por parte de estudiantes universitarios y de escuelas secundarias. La movilización estudiantil, en contra del sistema educativo chileno, es considerada como una de las más significativas de ese país.

Las redes sociales jugaron un papel importante dentro de esta situación. Las mismas fueron claves en la organización y convocatoria del movimiento, además de ser utilizadas para difundir ideales, los motivos de la lucha, es decir para expresarse y estar conectados.

El uso de las redes sociales, dentro del movimiento estudiantil, demostró que las tecnologías son un elemento fundamental dentro de cualquier movimiento social. Como afirma la Doctora en Ciencias de la Información, Migdalia Pineda de Alcázar (2005), son múltiples las iniciativas y redes ciudadanas que se han valido de Internet y de los medios digitales para hacer que la gente de distintos lugares construya discurso comunes y 
establezca vínculos para levantar temas, y de esta manera lograr articular acciones conjuntas globales y locales de cooperación y de relaciones sociales solidarias en torno a problemas contemporáneos en la ecología, los derechos humanos, la discriminación de la mujer, los indígenas y las minorías étnicas y lingüísticas, la protección de los menores y los jóvenes, los movimientos anti-globalización económica, entre otras.

Con la movilización estudiantil chilena se utilizó Internet como un espacio de encuentro, conexión y de participación de individuos, en torno a un hecho social, que mutaba días tras día, que mantuvo en vilo a la sociedad de Chile y que traspasó las fronteras entre diferentes países. Un escenario propicio para organizarse y llevar a cabo una acción determinada.

El amplio universo que se suscitó con la emergencia de la tecnología, permitió un predominio tecnológico sobre lo cultural, un interés económico sobre lo social. El entramado de poder que existe detrás de los medios de comunicación posibilita la incidencia nociva de la tecnología dentro de las sociedades.

A pesar del deslumbramiento que provoca Internet, no debemos convertirla en un panegírico a las nuevas tecnologías, sino que debe seguir siendo estudiada, observada e interpelada permanentemente. 


\section{TEORÍA DE LOS SEIS GRADOS}

En la actualidad es habitual mencionar el término redes sociales. Pareciera que es una noción relativamente nueva, que apareció en un determinado momento y que se instaló entre nosotros. Sin embargo esto no fue así, debido a que el término presenta una larga trayectoria.

En este sentido, lo que pretendo es, precisamente, aportar algunos aspectos relevante en torno al surgimiento de las redes sociales, que ocurrió en la primera mitad del siglo XX.

El concepto de redes sociales parte de Ea teoría de los seis grados", en la que se enuncia que toda persona que vive en el planeta tierra puede estar conectada con otra, a través de seis individuos.

La teoría que fue creada en el año 1930 por el escritor húngaro Frigyes Karinthy, formula que cada persona conoce aproximadamente 100 personas (amigos, familiares, compañeros de la universidad, escuela, trabajo). Si cada uno de las personas conocidas se relaciona a su vez con otras 100 personas, cualquier hombre puede transmitir un mensaje a 10.000 hombres más si le pide a un compañero que envíe el mensaje a sus conocidos.

Si esas 10.000 personas conocen a otras 100 , se tendría una red de 1.000 .000 de individuos conectados, y así sucesivamente hasta llegar en solo seis pasos a 1.000.000.000 de personas conectadas, demostrando esta teoría que se puede estar en contacto con cualquier persona del planeta tierra.

De este modo, nace la teoría sobre que es posible contactarse con cualquier persona del mundo, más rápido de lo que pensamos alguna vez. Según la especialista en marketing digital, Rosaura Alastruey (2010), seis intermediarios, sin importar la ubicación geográfica, son necesarios para que se propague un mensaje, considerando al emisor y al receptor.

Con el paso del tiempo, la teoría fue retomada, en el 2013, por el sociólogo Duncan Watts, en su libro Seis grados: la ciencia de una edad concentrada. En su escrito, Watts 
afirma que se puede contactar a cualquier persona del mundo solamente a través de seis saltos, que serían lo que comúnmente se conocen como correos electrónicos.

Watts (2003) expone que el hecho de que conozcamos las reglas que rigen el comportamiento de los individuos no siempre nos ayuda a predecir el comportamiento de la muchedumbre; sin embargo, en ocasiones podemos predecir el comportamiento de la muchedumbre sin conocer prácticamente nada de las personalidades y características únicas de los individuos que la forman.

La teoría permitió demostrar cómo las redes sociales pueden crear relaciones impensadas a partir de la emisión de un mensaje. Además de ratificar las múltiples conexiones que se pueden establecer con personas que viven en lugares lejanos, difícil de acceder si no fuera por la existencia de las redes sociales.

A su vez, las redes sociales forman parte de la llamada Web 2.0, es decir, sitios web que permiten a los usuarios crear contenidos fácilmente, sin necesitar conocimientos técnicos, como por ejemplo sobre programación. El término web 2.0 fue acuñado por Tim O’Reilly en 2004 para referirse a una segunda generación de Web basada en comunidades de usuarios y una gama especial de servicios, como las redes sociales, los blogs (...) que fomentan la colaboración y el intercambio ágil de información entre los usuarios. La web 1.0 eran páginas estáticas HTML que no se actualizaban frecuentemente" (Muñoz González 2010: 7).

El concepto Web 2.0 se originó sobre los cimientos de Napster (primer servicio de distribución de música que permitía compartir música entre los usuario) creado en 1999, el mismo año en el que aparecieron los blogs. Este contexto fue el indicado para el surgimiento de usuarios, que puedan crear sus propios de contenidos y subirlos a la web.

En la web 2.0, los usuarios son los creadores de los contenidos, los cuales son compartidos con otras personas. A diferencia de la web 1.0, en la que el usuario se limitaba solamente a leer el contenido que publicaba el administrador de la página, es decir que no podía hacer comentarios ni compartir la información de la web. 


\section{ORÍGEN}

Para conocer los orígenes de las redes sociales, debemos remontarnos al año 1995 , cuando el ingeniero industrial Randy Conrads, creó un sitio web llamado Classmates.com, una especie de red social pensada para que la gente pueda recuperar o mantener el contacto con compañeros de colegio, universidad, trabajo. Dicho sitio fue creciendo en popularidad, y le permitió a Conrads ser reconocido mundialmente.

En 1997, nace Sixdegrees.com, un sitio en el que los usuarios podían crear sus propios perfiles, listas de amigos, hasta enviar mensajes.

El éxito a nivel mundial llegó en el 2003 con MySpace, promocionándola como una red de círculos de amigos en línea. La red funciona con un usuario que debe crear un perfil, a través del cual puede agregar amigos. Además, dispone de un muro en el que se pueden escribir mensajes, colgar videos, publicar fotos. Dichas actividades también se pueden realizar en el muro de otra persona. Con la aparición de Facebook comenzó a dejar de utilizarse esta red social.

En el mundo digital existen diversos tipos de redes sociales:

- Focalizadas en relaciones de amistad:

Badoo: dispone de una sala de chat, a la cual se puede ingresar con la creación de un perfil. Es un sitio de citas que tiene como objetivo establecer vínculos amistosos y/o encontrar pareja.

Hi5: permite hacer de una cuenta de usuario una tarjeta de presentación virtual, que contiene información personal como gustos, hobbys, y demás. Es utilizada mayormente en América Latina. 
- Vínculos profesionales:

LinkedIn: es una red mundialmente reconocida por el éxito en el momento de conseguir empleo. También, permite mantener contacto con colegas en cualquier lugar del mundo. Posibilita tener una Currículum Vitae en línea, generando un enlace por cada usuario que puede ser utilizado como un sitio web.

Xing: mantiene una presencia destacada entre los directores comerciales de diversas empresas. Permite gestionar eventos y crear grupos de acuerdo a un conocimiento, área de interés en común. Tiene un gran protagonismo en Europa.

Se calculan más de 200 sitios de redes sociales de Internet. La popularidad de estos sitios creció rápidamente y grandes compañías han entrado en el espacio de las redes sociales en Internet. Un caso es Google cuando lanzó Orkut el 22 de enero de 2004. Otro buscador como Yahoo creó su red social en el año 2005 (De Alsola, 2011).

En el año 2004, nace la red social Facebook. Fue tal el crecimiento de dicha red y su vigencia, que en la actualidad cuenta con más de 6.000 empleados y 1.200 millones de usuarios activos por mes.

Por su parte, Twitter se origino en el año 2006. En el marco de una serie de reuniones de jóvenes emprendedores que trabajaban para la compañía de Podcasts Odeo, Inc., de San Francisco, Estados Unidos. Jack Dorsey propuso una idea en la que se podrían usar mini mensajes para decirle a un grupo pequeño lo que una persona estaba haciendo.

Una vez iniciado el proyecto probaron varios nombres. El nombre original fue "Status" (Stat.us), pasando por twitch (tic) a causa del tipo de vibraciones de los móviles, pero finalmente decidieron llamarlo Twitter. La definición era "una corta ráfaga de información intrascendente", el "pío de un pájaro", que en inglés es twitt. En el año 2007, Twitter pasó de 20,000 tweets al día a 60,000. El servicio rápidamente comenzó a ganar adeptos y en marzo de 2007 ganó el premio South by Souhwest Award en la categoría de blog, según el Licenciado en Mercadotecnia, Iván Visón (2010). 
Existe un debate sobre si Twitter es o no es una red social. Como expuse anteriormente, en el año 2007 ganó un premio pero dentro de la categoría de blog, no de red social. En el campo teórico no hay un acuerdo sobre la condición de Twitter, incluso Jack Dorsey, co - fundador de Twitter, explicó que: Twitter no es una red social, es para que todo el mundo sepa qué haces al momento (...) es una nueva forma de comunicación (...) Concretamente lo que mejor hace Twitter es simplificar la comunicación entre la gente expresar las tendencias de lo que está pasando en cada ciudad y en el mundo, además de forzar la interacción entre los individuos, que posteriormente se relacionarán cara a cara" 10 .

Algunas investigaciones como la del Doctor en Ciencias de la Información, José Luis Orihuela, cataloga a Twitter como una red social, que revolucionó la comunicación con solo 140 caracteres. Twitter es breve, global, hipertextual, intuitivo y social. Es una red en la que cada usuario define el contenido que recibe en función de las comunidades que establece.

Continuando esta posición, la Magister en Comunicación e Información, Ana Brambilla (2011) expone que Twitter es una red social debido a que dispone de ciertas características propias de las redes: como actores que pueden ser personas, instituciones; además de desarrollar conexiones asociativas a través de la interacción (retweet) y la construcción de lazos sociales.

Sin embargo, es posible sostener que a pesar de que para algunos teóricos Twitter es considerada una red de información, esto no significa que no sea una red social. Una característica no anula a la otra. Ambas pueden convivir perfectamente juntas.

Una red social también tiene como una de sus funciones la de transmitir información. Cuántas noticias de índole política, económica y del espectáculo nos enteramos por Twitter, y luego son retwitteadas y comentadas por los usuarios. Por lo tanto, considero a Twitter como una red social a través de la cual se busca información e interacción.

10 http://www.elmundo.es/elmundo/2009/03/25/navegante/1237985543.html (Consultada: 5 mayo 2014). 
Las redes produjeron una transformación en las formas comunicativas que tradicionalmente mantuvieron los mass media. A través de las redes sociales, circula información en la sociedad, que no es alcanzada por el control de los mass media.

Formamos parte de un cambio en el proceso comunicativo que conlleva una interacción multidireccional, dando paso a una comunicación construida entre todos. En paralelo a la transformación de la red, y al cada vez más evidente protagonismo de un creciente número de usuarios de la misma, se empieza a potenciar de forma extraordinaria, las relaciones entre dichos usuarios. Así, surgen diversas herramientas y estilos de uso de la red que potencian las relaciones entre las personas, y es aquí, en esta tendencia que empieza a convertir por fin Internet en una red de personas REAL, donde podemos situar el nacimiento de las redes sociales” (Castañeda, González y Serrano 2011: 48).

Pertenecemos a una era donde la interacción, mediada por la tecnología, sobresale permanentemente. Donde prima el poder participar, pertenecer de algún modo, no quedarse relegado. El protagonismo es de los usuarios, quienes participan de forma activa en la creación y organización de los contenidos, produciendo información que es compartida por otros usuarios al instante. Alejándose de esta manera a las críticas sobre las formas de comunicación unidireccional que caracterizaba a los medios de comunicación tradicionales.

Surgen algunos cuestionamientos, en el momento de referirnos a las redes sociales: ¿Quién es el dueño de esa información? ¿Quién la publicó o quienes la compartieron?.

A pesar de la inmediatez, masificación, velocidad con la que se produce la información y se comparte entre numerosos usuarios, se focaliza en quién fue la persona que subió determinado contenido y en la información en sí. Sin embargo, en algunos casos, si bien hubo una primera persona que publicó determinado video, nota; es tal la velocidad de la difusión que tienen las redes sociales, que a lo largo del trayecto se van perdiendo diferentes eslabones, que estuvieron presentes en el comienzo, como por ejemplo el contexto, la intención, los motivos. 
Se debe revalorizar la figura del usuario, más allá del avance de la tecnología. No se debe permitir que con la proliferación constante de la industria digital, el usuario llegue a perder el control que conquistó. A veces, con solo retwittear o compartir determinada idea o información en Facebook, no basta para conocer o profundizar en las verdaderas causas de una publicación.

Los usuarios experimentan constantemente con las redes sociales, con un espacio que se redefine permanentemente, y cuyos significados son puestos en juego por ellos mismos. Quizás el propósito de las industrias digitales sea mantener al usuario en una experimentación continúa, provocando suspenso, incertidumbre y principalmente seduciéndolo, provocando su atención. A veces la novedad y la fascinación hacia la tecnología, produce un deslumbramiento que no permite elaborar una postura crítica sobre este fenómeno.

Detrás de las industrias digitales subyacen grandes empresas con un gran poder e interés económico. Un caso representativo, es el de los canales de televisión argentinos, que disponen de redes sociales oficiales, a través de las cuales promocionan sus programas de televisión. En el caso de las tiras, suben adelantos, backstage, fotos, capítulos anteriores. El usuario hace uso de las redes sociales, se apropia de diferentes formas. Opina, debate, muestra su aceptación o disconformidad por alguna situación en particular o por un personaje determinado, plantea inquietudes, propone nuevos rumbos para la historia.

Las redes sociales constituyen un negocio y por esta razón los medios de comunicación hacen un uso de ellas. Representan un gran mercado de la economía global, a través de los ingresos que perciben con la publicidad, juegos, y demás herramientas. Constantemente luchan en la competencia para lograr captar la mayor cantidad de usuarios.

La competitividad entre los canales de televisión conduce a que en las redes sociales específicas de una tira se busque cautivar nuevos usuarios, priorizando el debate, la opinión, y no prestando atención en el porqué de lo dicho. 
En el Facebook oficial que poseen las tiras se focaliza en los comentarios que publican los usuarios, en el intercambio que se da entre ellos. Como explica el Doctor en Comunicación, José Luis Braga to que advertimos es, entonces, un flujo comunicacional continuo y hacia adelante. Después de la apropiación de los sentidos de un mensaje cualquiera, sus receptores siempre pueden poner en circulación en el espacio social una respuesta. Esta respuesta, independiente de un retorno inmediato, sigue adelante en procesos diferidos y difusos. Eventualmente, en el conjunto de la circulación y por el entrecruzamiento cultural de los múltiples circuitos, las ideas, proposiciones, imágenes, posiciones polémicas y tendencias expresadas se refuerzan, se contraponen, desaparecen o retornan. El retorno (...) es el del circuito ampliado y no la vuelta inmediata al punto de partida". (Braga 2012: 49).

Continuando con esta perspectiva, más allá de que los comentarios surgen a partir de una publicación diseñada por los creadores del Facebook de la tira, dicha publicación no es el objeto inicial, de un recorrido a seguir, esto significa que sería solo un momento de un circuito que comienza antes y continúa después.

En el caso del Facebook oficial de la tira Guapas (https://www.facebook.com/\#!/guapas.eltrece?fref=ts ), el disparador es una frase de uno de los personajes protagónicos de la tira, junto a una pregunta para los usuarios: 
Guapas - Página oficial

Ayer (a)

¿Pensás igual que Mey?

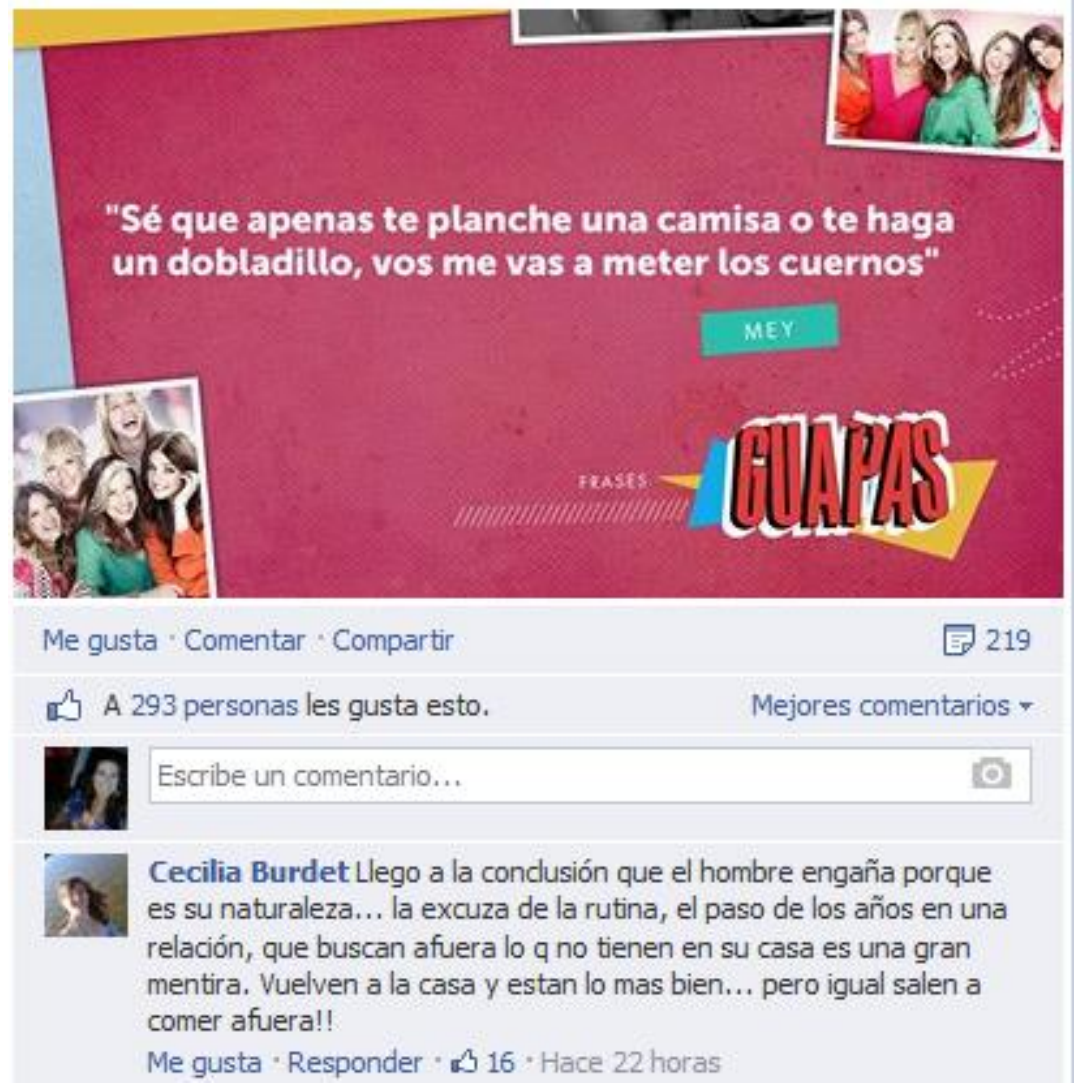

Imagen de una publicación en el Facebook oficial de Guapas (Mayo 2014)

Las frase que emitió el personaje tiene un detrás. Se inscribe en un contexto donde "Mey" está inmersa. Los usuarios conocen algunos rasgos del perfil, las conductas del personaje, por lo tanto, la publicación fue solamente un eslabón de la cadena que preexiste y sigue a la historia.

En este escenario, los comentarios que realizan los usuarios, son los elementos fundamentales del circuito, los cuales movilizan, interpelan, retroalimentan a los otros comentarios, que en algunos casos responden a uno anterior o que se separan del resto, 
generando nuevas preguntas. En el caso de las ficciones, generalmente no se focaliza en quién fue la persona que escribió un comentario, a menos que escriba un protagonista o un integrante del equipo de la tira. 


\section{CONCEPTOS SOBRE $\mathcal{L} \mathcal{A S}$ REDES SOCIALES}

A comienzos del siglo pasado era extraño pensar que la sociedad contemporánea conviviría en una era digital, interconectada permanentemente a través de diversos dispositivos electrónicos. Si bien el desarrollo de los medios de comunicación mediado por el avance tecnológico vislumbraba un futuro prometedor, la realidad superó cualquier fantasía posible.

El ser humano se encuentra inmerso en una cultura en red. Esto no significa que la sociedad actual anuló a la anterior, si no que fue modificada por la evolución constante de la tecnología.

En búsqueda de una teoría que sea afín a mi objeto de estudio y sea útil para seguir avanzando en la investigación, opté por seleccionar la teoría Sociedad Red, presentada por Manuel Castells, la cual es retomada en esta tesis para lograr comprender cómo las redes sociales son un reflejo de la sociedad red, y de qué manera esta última es una característica de la sociedad contemporánea, es decir, para poder explicar las nuevas formas de relación social dentro de la sociedad contemporánea.

Poder cruzar un paralelismo entre ambas sociedades, me permitirá distinguir las continuidades que presentan ambas, mediadas por un contexto donde la tecnología es la protagonista de la escena.

El teórico afirma que Internet constituye la base material y tecnológica de la sociedad red. Esa sociedad red posee una estructura social construida en torno a redes de información. Internet es el medio de comunicación que constituye la forma organizativa de las sociedades, es el equivalente a lo que fue la factoría en la era industrial o la gran corporación en la era 
industrial. Internet es el corazón de un nuevo paradigma sociotécnico que constituye en realidad la base material de nuestras vidas y de nuestras formas de relación, de trabajo y de comunicación. Lo que hace Internet es procesar la virtualidad y transformarla en nuestra realidad, constituyendo la sociedad red, que es la sociedad en que vivimos.

La Sociedad Red presenta una estructura comunicativa que contiene un conjunto de nodos interconectados, los cuales algunos absorben mayor información que otros. Los nodos que permiten alcanzar objetivos dispuestos por la misma red, son denominados nodos centro, debido a que tiene mayor importancia o generan más impacto que otros por la cantidad de información que gestionan. Los nodos aumentan en importancia para la red cuando absorben más información importante y la procesan más eficientemente. Sin embargo, cuando los nodos dejan de ser necesarios para cumplir los objetivos de las redes, éstas tienden a reconfigurarse, eliminando algunos de ellos y añadiendo otros nuevos. Los nodos existen y funcionan exclusivamente como componentes de las redes. La red es la unidad, no el nodo.

Como enuncia Castells, lo que un nodo es concretamente, depende del tipo de redes a que nos refiramos. Las redes enlazan instituciones, organismos, empresas y medios de comunicación. La situación de cada individuo depende tanto de su inclusión en la red, como del lugar que ocupa en esta estructura.

Produciendo una correlación con las redes sociales, en este caso, los nodos serían los usuarios. Sobre un escenario mediado por la tecnología, estos producen mensajes que se expanden en diversas direcciones entre otros usuarios (nodos).

De este modo, las redes sociales conforman un espacio propicio para que los usuarios estén interconectados, de manera tal que posibilitan un modelo de comunicación multidireccional a través de Internet.

Luego de haber comenzado trabajar sobre las redes sociales, es necesario destacar que en diversos ámbitos, se suele hacer referencia a diferentes redes sociales, pareciendo 
que la mayoría de las personas tiene conocimientos sobre el significado de las mismas. Sin embargo, el poder acceder a una red social determinada y saber utilizarla, no significa que se tenga noción sobre su significado.

Numerosos especialistas, investigadores intentaron definir a las redes sociales. A continuación se realizará una revisión de algunos conceptos.

- Manuel Castells (2001) expresa que las redes sociales son redes electrónicas autodefinidas de comunicación interactiva, organizadas en torno a un interés o propósito compartido, aunque a veces la comunicación se convierte en sí misma en la meta.

- Los especialistas en tecnología, Danah Boyd y Nicole Ellison (2007) definen a las redes sociales como servicios basados en la Web que permiten a los individuos construir un perfil público o semipúblico dentro de un sistema delimitado, articular una lista de usuarios con los que compartir, y ver y explorar esa lista de conexiones y otras realizadas por otros usuarios dentro del sistema.

- El Doctor en Sociología, Marcelo Urresti (2008) define a las redes sociales como generadoras de una tendencia creciente hacia la producción de contenidos y el desarrollo de aplicaciones por parte de los usuarios que han propiciado el surgimiento de nuevos regímenes de producción, consumo y circulación de contenidos, una tendencia marcada de la llamada web 2.0 con multitud de nuevas herramientas y programas que se suma a las nuevas formas de cooperación y sociabilidad que se generan en torno a los grupos que trabajan desde el software libre. 
- Según la investigadora Tamar Weinberg (2009) las redes sociales son páginas web que permiten que los individuos se conozcan entre sí, a partir de un perfil creado por ellos mismos, en el que reflejan sus intereses. Generalmente se utilizan para conectarse con antiguos amigos o encontrar nuevos.

- El Sociologo Nicholas Christakis y el Doctor James Fowler (2010) definen a las redes sociales como un conjunto organizado de personas formado por los seres humanos y las conexiones entre ellos. Los autores realizan un paralelismo entre las redes sociales reales y cotidianas, las cuales evolucionan orgánicamente a partir de la tendencia natural de toda persona a establecer relaciones de amistad, familiares y laborales; y las redes sociales ciberespaciales, que se desarrollan a través de Internet. Los autores explican que ambos tipos de redes sociales son un superorganismo vivo, aunque una característica que distingue a los mundos virtuales del real es nuestra capacidad de controlar nuestra presencia.

Los diversos autores coinciden en asociar a las redes sociales con diferentes verbos como, conocer, conectar, compartir, explorar, ver, sociabilizar. Parecería que estos conceptos giraran constantemente en la definición de redes sociales. Sin embargo, considero que la definición puede abarcar otros caminos.

A través de las redes sociales se exponen ideas, se evidencia una implicancia personal, se exhibe una percepción sobre determinado objeto. La participación en las redes sociales, ya sea de un modo pasivo o activo, se produce en un contexto, presenta una intencionalidad, no es inocente, depende de quién lo pronuncie, en qué situación y para quién.

No significa lo mismo lo que puede llegar a decir un político en su Facebook oficial, que lo que publica un usuario en su cuenta de Twitter sobre una ficción determinada. El reconocimiento, la popularidad y el poder que tiene un usuario como puede ser la Presidenta, implica que sus dichos se propaguen o generen repercusión. 
Si bien las redes sociales son un lugar de intercambio, conexión y conocimiento, también son numerosos espacios virtuales en el que las personas crean y manifiestan un perfil, que puede coincidir o no con la real. En ese sitio, se podrá vislumbrar preferencias, gustos, ideales, conocimientos que conforman el perfil de cada usuario.

Las redes sociales presentan significados, de acuerdo al uso que se le esté dando. Algunos usuarios la consideran como un lugar para conectarse con otros, como un campo para compartir ciertos contenidos, o simplemente para conocer gente.

Coincido en la definición de Manuel Castells debido a que las redes sociales se caracterizan por una comunicación interactiva, que provoca un flujo comunicativo que invita a la participación de los usuarios. Sumado a la conceptualización propuesta por Urresti, al asociarlas a la producción de contenidos y el desarrollo de aplicaciones por parte de los usuarios, a quienes menciona como responsables de la producción, consumo y circulación de contenidos dentro de la web 2.0.

Danah Boyd, Nicole Ellison y Tamar Weinberg caracterizan a las redes a partir de la construcción de un perfil que posibilita conectarse con otros usuarios. Las redes sociales permiten una interrelación, una comunicación multidireccional entre diversos usuarios, quienes se unen a una red determinada, por una razón, ya sea laboral, educativa o de esparcimiento y entretenimiento.

Una definición novedosa es propuesta por Nicholas Christakis y James Fowler, al asociar a las redes sociales reales con las virtuales. Es interesante poder relacionarlas, partiendo de que toda persona posee una tendencia natural a establecer relaciones. De esta manera, permite demostrar que ambos tipos de redes no se contraponen pero si se diferencian en el plano en el que se desarrollan.

Considero que las redes sociales crean un escenario ideal para integrar a los distintos medios de comunicación produciendo una red interactiva. Un caso es el de las audiencias televisivas, que mientras están mirando un programa de tv, están consumiendo desde su 
celular o computadora alguna red social, para hacer comentarios o simplemente leer lo que escriben otros sobre lo que están observando por la televisión.

Esta situación se manifiesta en un contexto mediado por la tecnología, que posibilita la proliferación de sucesivos smartphones (teléfonos inteligentes) que penetran en la cotidianeidad de las personas, permitiendo una conexión permanente a través de diversas plataformas digitales.

Los teléfonos móviles junto con las tablets son un ejemplo del tráfico digital por fuera de las computadoras convencionales. Estos dispositivos móviles lograron que la conectividad en movilidad sea un elemento influyente en los usos de las redes sociales. La posibilidad de publicar o comentar determinada información en tiempo real, crea una instantaneidad inimaginable en tiempo pasado.

En este escenario, redes como Facebook permiten poder compartir con otras personas, un producto televisivo. Creando de esta manera, una falsa proximidad, es decir una cercanía virtual, una compañía donde a través del plano digital, se ponen en juego emociones, pensamientos, reflexiones.

A pesar que la creación de una página de Facebook dedicada a una tira agrupe a los fanáticos de la misma, que pretenden informarse, compartir opiniones, conocer novedades o adelanto, esto no significa que los usuarios tengan las mismas concepciones o ideas sobre la ficción. Incluso, se unen usuarios a quienes no les agrada la tira o algún actor en particular, escribiendo comentarios críticos sobre la trama o un personaje, generándose de esta manera, debates con los fieles seguidores de la ficción.

Son las redes sociales el espacio de reunión, de debate, un lugar latente que forma parte de nuestra realidad, que convive con nosotros, que está a disposición para iniciar una conversación o responder a un comentario en particular. Es el marco en el cual el usuario es el protagonista, desarrollando espacios de intercambios que forman parte o que son independientes de las redes sociales que disponen los medios de comunicación. 
Con la tira Dulce Amor ${ }^{11}$ (https://www.facebook.com/tlfdulceamor), se crearon diversas páginas de Facebook más allá de la oficial. Algunos usuarios prefirieron disponer de sus propias páginas dedicadas a la ficción, esto significa poder administrarlas, organizar contenidos, comentarios.

\footnotetext{
${ }^{11}$ Tira argentina, producida por L.C. Acción Producciones (Enri que Estevanez). Comenzó a emitirse el lunes 23 de enero de 2013 y finalizó el 29 de abril de 2013, en el prime time de Telefe. Protagonistas: Sebastián Estevanez, Juan Darthés, Carina Zampini, Pedro Cernadas y Laura Novoa. Guionistas: Enrique Estevanez, Marcelo Nacci y Laura Barneix. Directores: Hugo Alejandro Moser y Mauro Scandolari. El argumento se centra en la vida de tres hermanas, dueñas de la fábrica de chocolates Bandi. Victoria, la hermana mayor se enamorará perdidamente de su chofer Marcos, pero diversos inconvenientes atentarán contra la relación. La llegada de Marcos y su amigo Julián, otro chofer, enamorado de Natacha, la segunda hermana Bandi, cambiará el destino de la familia y las ayudarán a salvar a la empresa de la quiebra.
} 


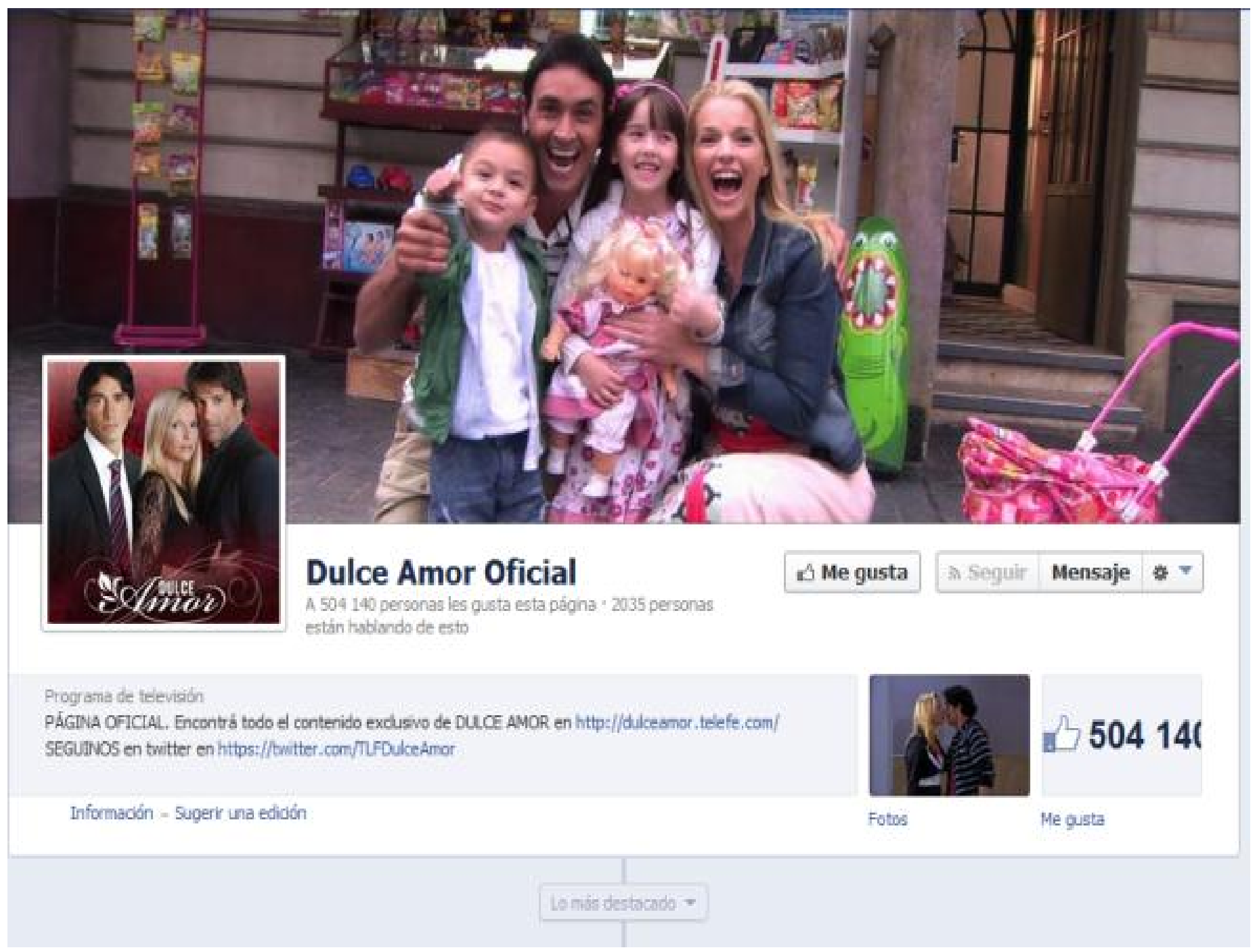

Imagen del Facebook oficial de Dulce amor. FUENTE:

https://www.facebook.com/tlfdulceamor (Consultada: 3 abril 2014). 
En el Facebook oficial de Dulce Amor, suben fotos y videos del backstage de una escena en particular. Los usuarios participan activamente de encuestas y Hangouts (aplicación que permite chatear entre numerosos usuarios, iniciando de esta manera conversaciones grupales). Dicha aplicación multiplataforma, permitió que los fanáticos de la tira, puedan realizarle preguntas al protagonista invitado a utilizar la plataforma.

Además se suben bloopers, adelantos de la ficción, saludos y mensajes de los protagonistas. La página es dinámica, los administradores de la página suben preguntas, fotos, video, permanentemente, situación que mantiene la participación activa de los usuarios.

Por otra parte, dentro de las páginas de Facebook no oficiales, creadas por los fanáticos de la tira, se pueden observar las siguientes: 


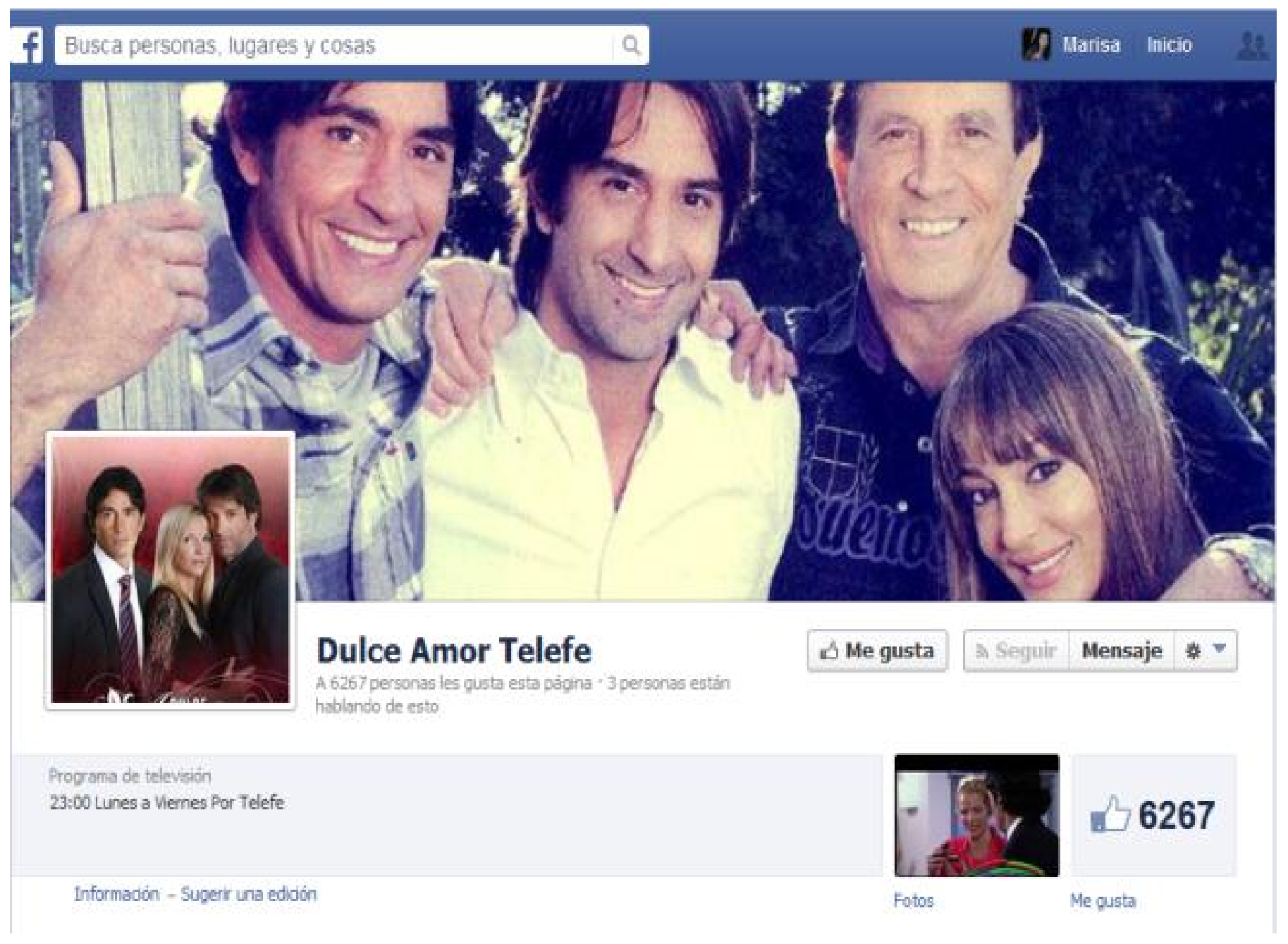

FUENTE: https://www.facebook.com/pages/Dulce-Amor-

Telefe/299931133382984?fref=ts (Consultada: 3 abril 2014). 
El mecanismo de esta página, se centra en preguntas acerca de la trama, si te gustó un personaje, cómo consideras que va a continuar la historia, si van a ver el capitulo que se emitirá a la noche. También se suben videos con adelantos, fotos del backstage, extraídos de la página oficial de la tira.

En el Facebook se publican entrevistas que les realizaron a los protagonistas en diferentes medios gráficos o anticipan si alguno de los actores estará presente en un programa de televisión.

Si bien es menor la cantidad de usuarios que dispone esta página, respecto a la oficial, los usuarios participan de las consignas propuestas por el creador de la página, a través de un comentario o poniendo "me gusta" en una publicación en particular. 


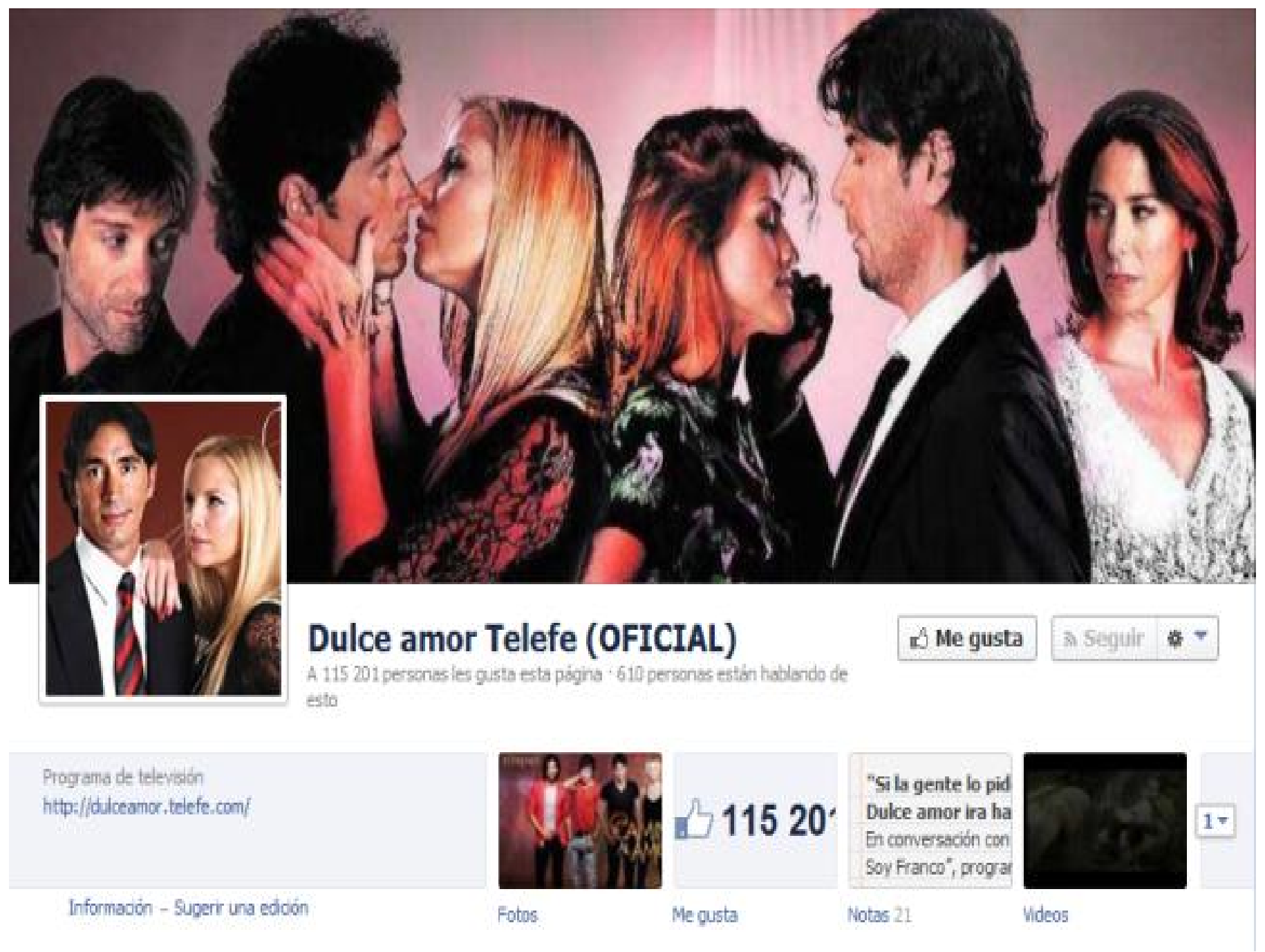

FUENTE: https://www.facebook.com/DulceAmorTLF?ref=ts\&fref=ts

(Consultada: 3 abril 2014). 
A pesar de que esta página aclara que es oficial, no lo es. Se encarga de publicar fotos, videos, entrevistas que fueran subidas a la página oficial de la tira y hasta hace uso de la dirección de la página web de Telefe dedicada a la ficción. Además, presenta una gran cantidad de usuarios que participan activamente de las preguntas que propone el administrador de la página.

Este caso demuestra las falsas identidades que se pueden crear en las redes sociales, cómo se puede engañar a los usuarios que creen estar participando de una página oficial, cuando en realidad esto no es así.

Un concepto interesante para comprender otra característica constituyente de las redes es otorgado por la Doctora en Comunicación e Información, Raquel Recuero (2009) al afirmar que una red social se define por dos elementos básicos: actores (personas, instituciones o grupos) y sus conexiones (interacciones o lazos sociales). Los actores serían los nodos, partes del sistema que actúan con el fin de dar forma a las estructuras sociales, por medio de la interacción y de la construcción de lazos sociales. Pero al referirnos a redes sociales en Internet, los actores son representaciones de actores sociales, que pueden ser representados por una cuenta en Twitter o un perfil en Facebook.

En este contexto de redes sociales, la palabra actor no es una persona sino una función, uno pasa a convertirse en seguidor de alguien o algo con la aplicación -Seguir", o en Fan, con la herramienta Hacete Fan" de Facebook.

Resulta interesante destacar como dentro de las redes sociales tomamos diferentes funciones de acuerdo a nuestros intereses y afinidades. Como nos convertimos en múltiples representaciones, las cuales pueden ir mutando a través del tiempo.

Continuando con esta reflexión, cada actor es una mera representación en sí mismo, esto significa, lo que se pretende mostrar de mi a los otros, algo que estoy queriendo decir sobre mí.

Aunque las redes son un espacio para la comunicación con otros usuarios, también son un medio para transmitir información, desde un diario o canal de televisión, un actor, 
hasta una empresa publicitando un objeto o servicio determinado. Tanto la visibilidad como la popularidad que caracterizan a las redes sociales, permiten que sean elegidas como un medio de difusión.

Las redes sociales son un fenómeno social que se propagó en todos los ámbitos. Medios de comunicación, empresas, organizaciones, pequeños y medianos emprendimientos, poseen una red para comunicarse y publicitar sus productos. En conclusión, las redes sociales son un nuevo medio de distribución, desde información, servicios, hasta cualquier producto que se quiera comercializar. Como afirma el investigador Luis Ángel Fernández Hermana (2008), las redes sociales no son solo un juego para el encuentro inesperado y sorprendente, sino espacios virtuales organizados para desarrollar proyectos, integrar comunidades de otra manera, poner en pie servicios que de otra manera no existirían, tomar decisiones en tiempos complejos y proyectarse hacia el mercado global usando toda la potencia de la virtualidad.

Respecto a la promoción en las redes sociales, como Facebook, que presenta un espacio para la publicación paga, en el lateral derecho de la pantalla, donde se publicitan productos, eventos, juegos, servicios, entre otros, Tamar Weinberg (2009) afirma que las redes sociales les permiten a las empresas incrementar el reconocimiento de la marca; la cantidad de personas hacia la página web de la marca o la empresa; construir un mayor número de enlaces en Internet, donde se hable de la página web y del producto del anunciante, aumentar las ventas; monitorear las conversaciones sobre la empresa, marca o servicio; y de este modo establecer el liderazgo.

Comúnmente, en redes sociales como Facebook, las empresas publicitan alguno de sus productos, desde viajes, vestimenta, accesorios, invitando a los usuarios a -empartir" o hacerse fan de la página en cuestión, anunciando por ejemplo, que a los 500 compartidos se ganan el premio que están sorteando.

Aunque la publicidad a través de las redes sociales no sea el tema a estudiar en la presente investigación, es necesario aclarar que también son utilizadas como herramientas para el marketing, estableciendo una muestra de las tendencias en relación a una marca en 
particular, es decir como un medio para la realización de estadísticas de opinión sobre un producto determinado.

Focalizándonos en la presente investigación que tiene como uno de sus objetivos analizar los usos de las redes sociales en la configuración de las audiencias televisivas de tiras argentinas, es decir cómo las redes sociales contribuyen a la configuración de las audiencias de una tira. En esta línea es interesante constatar los modos en que los usuarios, que se nuclean en torno a una ficción televisiva, hacen uso de las redes sociales para poder comunicarse, es decir cuáles son los usos que los usuarios hacen de este tipo de redes sociales. Entendiendo a las redes como un espacio de comunicación que posibilita la interacción de un grupo de usuarios alrededor de un producto televisivo.

Si bien este tipo de páginas presentan una lógica, que apunta a resolver las consignas propuestas por los administradores del Facebook oficial, o tiene una estrategia comunicativa detrás con la finalidad de interpelar a los fanáticos de una tira, esto no significa que los usuarios dejen de exponer sus opiniones, contentos o descontentos, ideas. Son los usuarios los protagonistas del Facebook de una tira, quienes le dan sentido a la página, a través de sus debates e intercambios.

La tecnología se convierte en proveedora del espacio comunicativo, ofreciendo herramientas tendientes a facilitar el uso de una plataforma digital, sin mayores complicaciones. El usuario es el que está en el medio, entre la tecnología y el uso que hacen los medios de comunicación con ella.

Se crea un Facebook oficial de una tira, utilizando las herramientas propuestas por la tecnología, haciendo participe a los usuarios de dicha página. Interpelándolos, movilizándolos, provocando en ellos alguna reacción que puedan exteriorizar por medio de un comentario.

Como mencioné anteriormente, los medios de comunicación son un negocio, que pretenden posicionar sus productos y atraer más audiencias, incitando la participación de los usuarios en las redes que dispone el canal de televisión. No les es indiferente, que la 
página de Facebook sobre una de sus tiras, tenga quinientas o más de un millón de usuarios comunicándose; como tampoco el tráfico y comportamiento de los usuarios en sus webs.

La búsqueda de complicidad y fidelidad es permanente, a través de la combinación de diferentes formas de comunicación que se integran en las redes sociales, atrayendo constantemente la atención de los usuarios.

Un caso concreto ocurrió con Telefe con respecto a la tira Dulce Amor, debido a que se utilizó una aplicación tecnológica como es el Hangouts, para permitir que los usuarios pudieran comunicarse en simultáneo con la actriz protagónica, Carina Zampini, un día y horario determinado. Las innumerables preguntas de los fanáticos con las consecuentes respuestas de la actriz, a través de una pantalla, permitieron que los usuarios se colocaran en el rol de periodistas por un momento, despejando sus inquietudes sobre Zampini.

Las preguntas fueron de indole personal, laboral, sobre su personaje y la continuación de la trama. Esta iniciativa permitió que fanáticos de la tira, no solamente de Argentina, sino de algunos países latinoamericanos, donde también se transmite la tira, puedan contactarse con su actriz favorita, expresando sus sentimientos, palabras, opiniones y hasta sugerencias hacia ella. 


\section{ESTE MIÉRCOLES \\ A LAS 16.30}

\#HANCOUT EXCLUSIVO CON

\section{CARINA} ZAMPIN

\section{Exceusivo con}

Me gusta - Comentar " Comparta

S) Q 69952

ch A 359 personas les gusta esto.

[. Ver comentarios anteriores

Imagen del anuncio del Hangout en Facebook oficial de Dulce amor (Enero 2013)

Luego de haberse llevado a cabo el Hangout, que duró más de una hora, el video fue subido en el canal de Youtube que dispone Telefe, y luego fue publicado en las redes sociales y en la web de la tira que dispone el canal de televisión. 

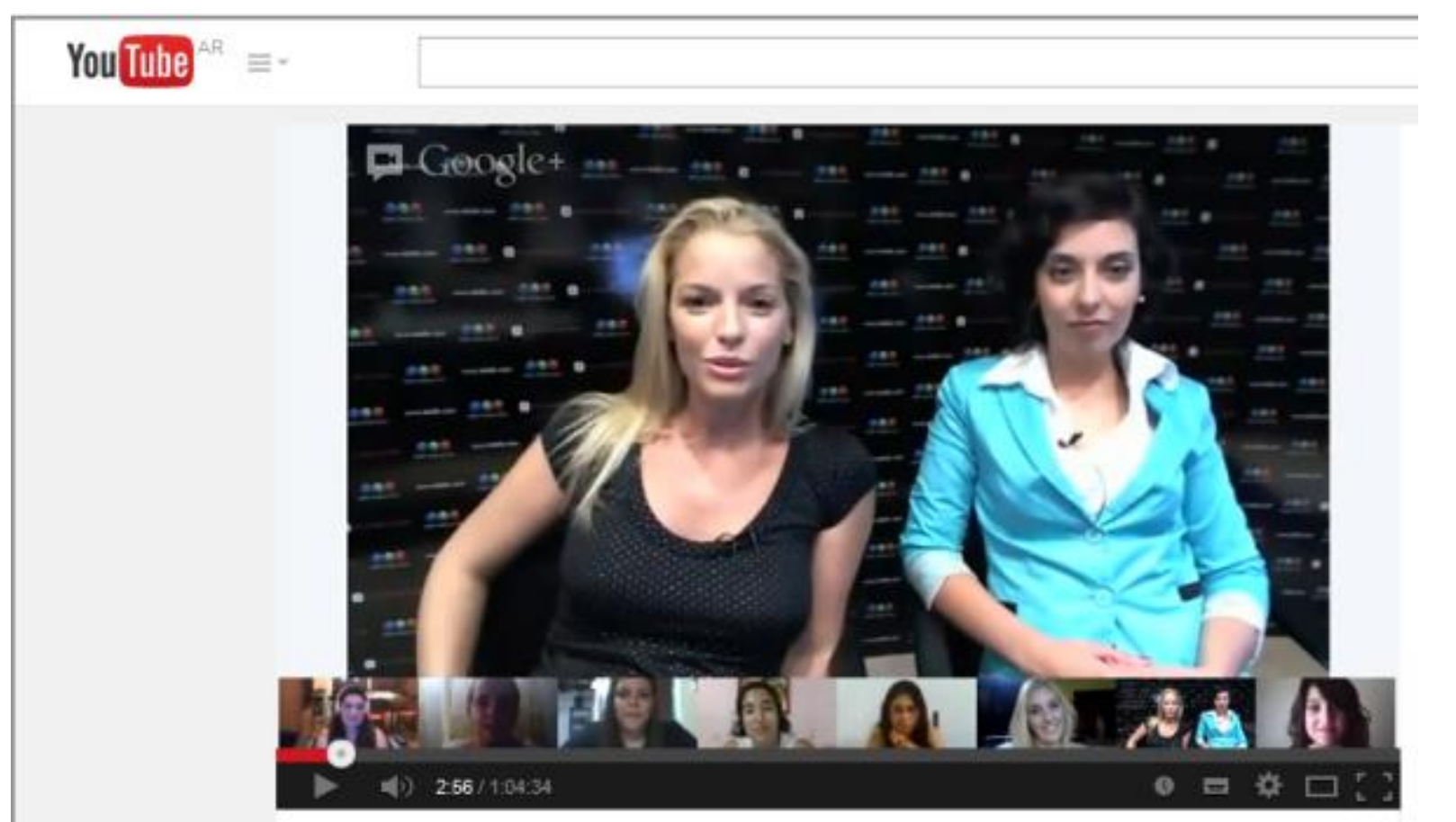

\section{Hangout con Carina Zampini}

Q5) Telefe a

$16529 \div 11$

Imagen del video sobre Hangout en el canal de Youtube de Telefe (Enero 2013)

FUENTE: https://www.youtube.com/watch?v=9SRIVgl9Fg4

La propuesta de la conversación grupal con la protagonista, fue íntegramente publicitada en las redes sociales oficiales dedicadas a la tira, así mismo en la web del canal, pero lo sorprendente es que no se hizo en televisión, aunque sea durante la transmisión de la tira.

A la fecha (julio de 2014), durante la trasmisión de la mayoría de las tiras argentinas se puede observar una falencia, debido a que no se da a conocer las redes sociales oficiales dedicadas a la tira, con la consecuente invitación a participar de las mismas. Siendo durante su emisión, un gran lugar desde el cual se pueden publicitar las redes y de esta manera obtener más seguidores. 
Ninguna de las tiras que ocupan el prime time de la televisión argentina presentan esta característica: Mis Amigos de Siempre (El Trece Tv), Guapas (El Trece Tv), Somos Familia (Telefe), Camino al Amor (Telefe), Señores Papis (Telefe).

Sin embargo, en industrias televisivas extranjeras, la situación es diferente. Medios como Televisa (México), realizan diferentes estrategias, para aunar lo que surge en la Televisión con las redes sociales. Cuando empieza o termina la tanda publicitaria de una tira, por unos segundos aparece alguno de los protagonistas, invitando a los fanáticos de la tira a participar de las redes sociales. También, muestran el logo de las redes cuando finaliza el capítulo.

Productoras internacionales como Televisa, sumergen sus ficciones en una plataforma interactiva, incitando e invitando constantemente a la participación de la audiencia. Un caso es la tira Lo que la vida me Robó (2014), que ocupa el prime time de ese canal mexicano, utilizando su página principal para publicitar el final de la tira, que será alternativo, uno transmitido por la televisión y otro en Internet, a través de un Web show, es decir una aplicación a partir del cual se podrán ver imágenes exclusivas, entrevistas con el elenco, fotos y videos, para palpitar el final. 


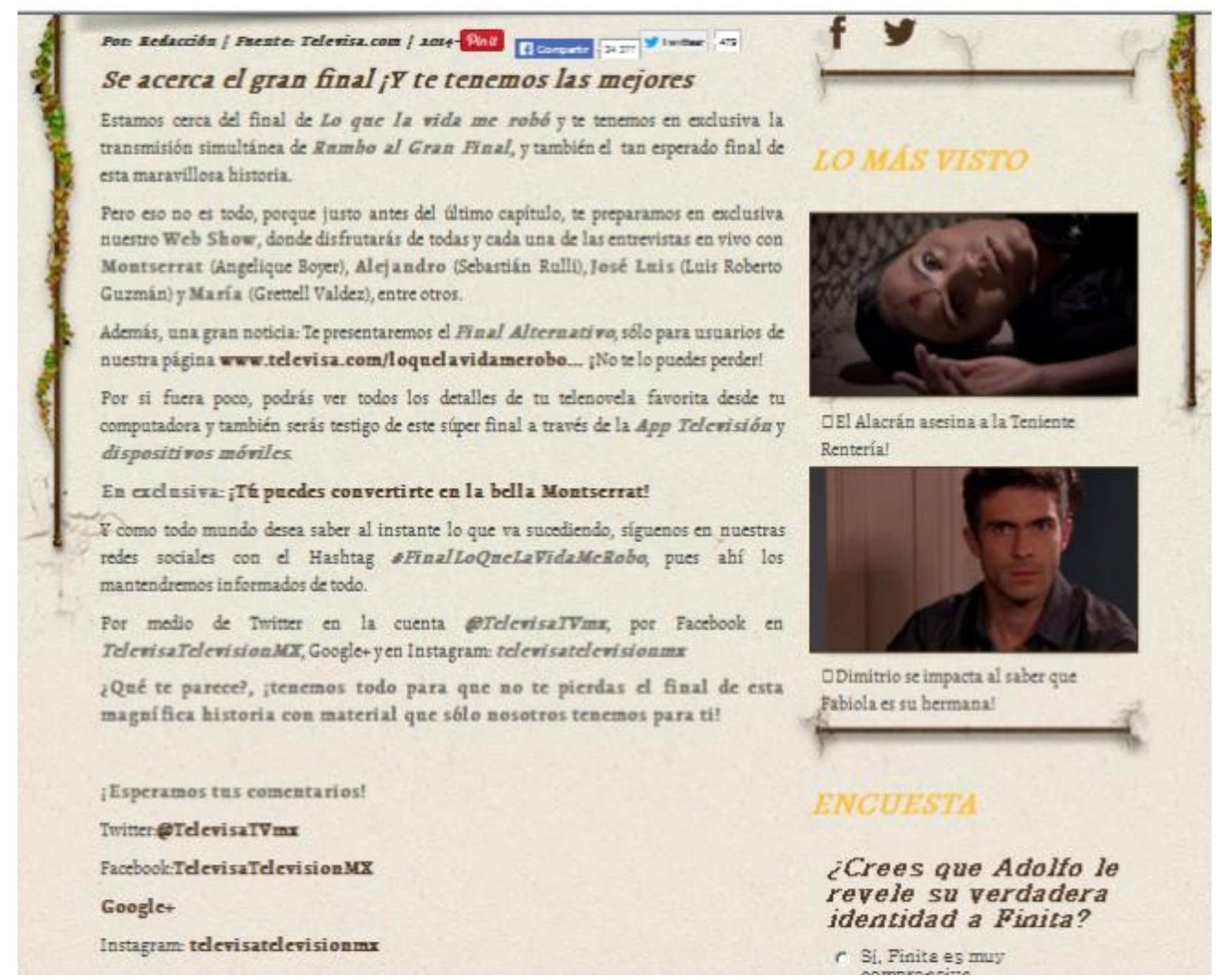

Imagen del anuncio del final de la ficción Lo que la vida me robó. FUENTE: http://www.televisa.com/telenovelas/lo-que-la-vida-me-robo/noticias/742539/se-acercagran-final-tenemos-mejores-exclusivas-vida-me-robo-fin/ (Consultada: 24 julio 2014). 
De este modo, Televisa despliega una serie de estrategias para captar a la audiencia, a través de Twitter con un Hashtag determinado, Facebok, Instagram, Google + y la página oficial, todas funcionado en simultaneo.

Otro caso es el del canal español Antena 3, que posee en las diferentes tiras, una plataforma integral, antes, durante y después de las ficciones, que convoca permanentemente a las audiencias a participar de las distintas herramientas digitales que poseen en las redes sociales y en la página oficial de la tira. A partir de la tira El secreto de Puente Viejo ${ }^{12}$ (2014), se realizan concursos, como la realización de fondos de pantallas, responder preguntas sobre la trama, incitando la participación.

Las diversas aplicaciones interactivas disponibles en ficciones televisivas permiten la constitución de una segunda pantalla al poder recibir contenidos exclusivos e inéditos en smartphones y tablets durante la transmisión de la tira, como fotos, vídeos, en relación a lo que está ocurriendo en la pantalla, con enlaces que permiten dirigirse a las redes sociales para seguir comentando sobre la ficción.

Una segunda pantalla donde el objetivo principal sea expandir la experiencia de ver televisión logrando que sea más social e interactiva, a partir de la participación de la audiencia en dicha plataforma.

Este tipo de pantallas, interconecta a las audiencias en torno a una ficción determinada, seduciéndolas para que participen de otro tipo de pantalla, que depende de la tradicional, como es la televisión, pero que presenta herramientas propias y características de la comunicación digital.

${ }^{12}$ En http://www.antena3.com/series/el-secreto-de-puente-viejo/eres-fan/concursos/ (Consultada: 24 julio 2014). 
Estos detalles, forman parte de una estrategia comunicativa, posibilitando una comunicación multidireccional a través del uso de multiplataformas destinadas a una ficción en cuestión. En la actualidad es imposible pensar en un canal de televisión que no disponga de redes sociales, para promocionar los contenidos del canal y de esta modo generar el interés de los usuarios y la consecuente participación en las redes específicas que poseen sobre cada programa de televisión.

Por último, las redes sociales sobre las tiras posibilitan la difusión de la información y la conquista de numeroso usuarios, creando una comunidad virtual participativa, logrando que esas mismas redes estén en constante movimiento, gracias a los usos otorgados por los usuarios. 


\section{TIPOLOGÍA DE REDES SOCIALES}

Las redes sociales se pueden dividir según la finalidad de uso, es decir el propósito rector para el que fueron diseñadas. Sin embargo, es necesario aclarar que ninguna sistematización se acaba en sí misma, sino que es el escenario para nuevas categorizaciones.

Por este motivo propongo una clasificación generalista para clarificar las principales características que las definen y a quiénes están siendo orientadas. Esto significa, conocer su lógica en el momento del registro y de esta manera, hacer uso de ellas.

\section{- Clasificación 1}

Redes sociales segmentadas: concebidas sobre una temática en particular, que agrupa a artistas, interesados en la cocina, o adeptos a un hobby determinado, por mencionar algunos casos. Están destinadas a un grupo de usuarios con intereses en común por la temática que rige a la red social. Un ejemplo de este tipo de redes es LinkedIn, orientada a profesionales. A través de esta red cada usuario puede dar a conocer su experiencia laboral, estudios, títulos, cursos intereses laborales.

Redes sociales no segmentadas: destinadas a un público genérico y no a un usuario definido. No presentan una única temática, debido a que el contenido como el público es variado. Como ejemplos de este tipo de redes sociales, se puede mencionar a Facebook. 


\section{- Clasificación 2}

Redes sociales ordinarias: diseñadas para el ocio y las relaciones personales. Se basan en la configuración de un perfil, en el que pueden aparecer fotos, gustos, intereses, estudios, y a partir del cual se interactúa con amigos, familiares, compañeros de trabajo, conocidos, aunque también sirvan para ser el punto de partida en el momento de entablar un contacto con personas que no se tiene un vínculo. También disponen de diferentes aplicaciones como juegos online. Ejemplos: Facebook, Badoo, Hi5.

Redes sociales profesionales: creadas para establecer contactos en el ámbito laboral. Requieren un perfil que presente la experiencia laboral y académica. Además, se debe hacer mención a las habilidades, motivaciones, intereses y expectativas. Los usuarios que utilizan este tipo de redes, saben que sirve como acceso a ofertas laborales y a posibles contactos estratégicos en el campo laboral. Ejemplos: LinkedIn, Xing.

Redes sociales específicas: abocadas a un tema en particular que es de interés común entre sus usuarios. Desarrollada para la interacción entre personas aficionadas a una temática, que intentan adquirir nuevos conocimientos, exponer los propios o simplemente expresarse y debatir con otras personas que comparte el gusto por cierto tópico. Ejemplos: redes destinadas a un famoso, un cantante o una banda.

Las diversas tipificaciones, permiten conocer las funciones que presenta cada una. Las ventajas y desventajas serán asignadas por los usuarios, de acuerdo a los usos que le quieran dar. Las diferentes tipologías están en movimiento permanentemente, diferenciándose, cruzándose e interpelándose mutuamente, dentro del mundo digital. 


\section{$\mathcal{F} \mathcal{A C E B O O K}$}

En la actualidad las redes sociales se convirtieron en plataformas de expresión y en un escenario a través del cual se puede acceder a la información que es de nuestro interés.

Como dije anteriormente las redes sociales son un fenómeno que crece constantemente. Continuamente emergen nuevas redes, con características particulares y destinadas a un usuario específico. La proliferación de diversos tipos de redes promueve la atracción y la consecuente participación de los usuarios.

Las redes sociales potencian las prácticas interactivas de los usuarios a través de la interrelación entre ellos y el intercambio de información. La comunicación en red se fortalece, se reinventa permanentemente.

La popularidad de una red junto a las posibilidades y herramientas que les brinda a los usuarios son características fundamentales en el momento de seleccionar una red social para estudiar.

Al decidirme a seleccionar una red social pertinente para ser analizada en esta investigación, escogí a Facebook por sobre otras, porque considero que representa una red que ofrece diversos usos, aplicaciones, servicios que intentan satisfacer las necesidades de los usuarios, y de esta manera, pelear el liderazgo dentro del mercado. Además de ser la red social más utilizada en Argentina, como se expondrá a continuación.

Facebook se supera constantemente para mantener y seguir conquistando usuarios. Un hecho demuestra, que en diciembre del 2013, Facebook cerró el año, con más de 1.230 
millones de usuarios activos por mes, mientras que a final del año 2012, disponía 1000 millones de usuarios ${ }^{13}$, según la Página Oficial de Facebook.

Con el propósito de conocer el consumo de una red social como Facebook en diferentes regiones, es necesario estudiar diversas estadísticas realizadas por consultoras especializadas en la temática.

La compañía de tecnología ComScore, dedicada a las mediciones del mundo digital, publicó un informe denominado Futuro Digital Latinoamérica 2013"14 en el cual expone datos sobre el estado de la industria digital, el consumo de Internet, redes sociales, y demás, en los países de la región.

Sobre el consumo de redes sociales, Latinoamérica, es el continente que registra un mayor tiempo conectado:

- De las cinco regiones globales, Latinoamérica fue la que más rápido creció en audiencia online, a una tasa del 12\% anual, superando los 147 millones de visitantes únicos en Marzo de 2013. Sin embargo, Asía Pacífico sigue liderando con el 41\%, Europa con el 27\%, dejando atrás a América del Sur con el 9\%.

- La población de Internet en América Latina se concentra entre Brasil representando más de 62 millones, México supera los 24 millones, y en tercer lugar se encuentra Argentina con más de 14 millones.

- Los usuarios latinos pasaron más de 10 horas por mes online en redes sociales, duplicando el promedio de consumo global.

\footnotetext{
${ }^{13}$ En https://newsroom.fb.com/Timeline (Consultada: 26 julio 2014).

14 En http://www.slideshare.net/kiklio/futuro-digital-latinoamerica2013by-comscore (Consultada: 26 julio 2014).
} 
- Los latinos consumen cinco horas más las redes sociales a diferencia del promedio global

Respecto a la utilización de Facebook en Latinoamérica:

- Facebook es el segundo sitio de Internet más utilizado en Latinoamérica, con un promedio de más de 56 millones de visitantes diarios, detrás de Google.

- La red social más utilizada en Latinoamérica es Facebook con más de 131 millones de visitantes, en segundo lugar se posiciona LinkedIn registrando más de 37 millones y en tercer lugar, Twitter superando los 29 millones.

- Sobre el tiempo consumido en redes sociales, Facebook predomina con el 94\%.

Focalizándonos en Argentina, es interesante observar cómo es el comportamiento de los usuarios. La compañía comScore realizó un estudio sobre el país, denominado Futuro Digital Argentina 2013"15:

- Facebook presenta más de seis millones promedio de visitantes diarios.

- La red social más utilizada es Facebook con más de 15 millones de visitantes, en segundo lugar Ask.Fm superando los 6 millones y en tercer puesto LinkedIn registrando más de 4 millones. Por su parte, Twitter quedó en cuarta posición con más de 3 millones.

\footnotetext{
${ }^{15}$ En http://www.slideshare.net/delgadocristian/futuro-digital-argentina-2013 (Consultada: 29 julio 2014).
} 
- En Argentina se consumen más de 24 hs online al mes.

- $89 \%$ es porcentaje de penetración que tiene Facebook entre los usuarios de internet.

El informe concluye en que Argentina es uno de los mercados más involucrados con las redes sociales. El crecimiento y la popularidad que presenta Facebook en Argentina y en Latinoamérica, hace que se convierta en la red elegida por los usuarios, en donde ellos encuentran un espacio apto para comunicarse e informarse.

En la actualidad Facebook es el líder de las redes sociales, sin embargo este posicionamiento no es eterno, sino que debe luchar diariamente por mantener su liderazgo ante las distintas redes que surgen y que se van consolidando con el tiempo. Tal fue el caso que mencioné anteriormente sobre MySpace, que fue la protagonista de las redes sociales, y durante el siglo XXI fue perdiendo su posición con la aparición de diversas redes, en especial Facebook.

También es importante destacar, según el estudio presentado anteriormente (Futuro Digital Argentina 2013), que Argentina es el tercer país del mundo con mayor consumo de redes sociales. Los usuarios argentinos son los que más hacen uso de la tecnología digital y las herramientas digitales a través de las redes.

La sociedad contemporánea vive inmersa en una sociedad en red en la que prevalece la interacción constante, la visibilidad, el poder comunicar y participar en ciertos debates. El traspaso de una comunicación lineal a una interactiva, es un cambio significativo en el momento de analizar el comportamiento de los usuarios.

Las posibilidades que ofrecen las redes sociales en materia de comunicación, como productora de interrelaciones, de intercambios instantáneos, permiten que las redes se conviertan en un sitio favorito para los usuarios. 
El tiempo no es un detalle menor si se quiere analizar otra de las razones del apogeo de las redes sociales. Debido a que están disponibles las 24 horas del día, y los 365 días del año. Siempre están a disposición de los usuarios, para cuando ellos lo requieran.

El escenario tecnológico en el que estamos inmersos propicia que la conexión a las redes sociales sea accesible a través de un celular o una tablet que llevamos con nosotros y que nos permite conectarnos en cualquier lugar en el que nos encontremos. Por este motivo, las herramientas tecnológicas son un puente para mejorar la participación a las redes sociales.

El impacto de las redes sociales se suscita en un contexto globalizado, en el que los usuarios demandan una participación constante en los sitios de su interés, generando de este modo, flujos comunicativos caracterizados por la interactividad y la comunicación multidireccional.

Otro estudio sobre las redes sociales fue desarrollado por la compañía Matomy Media Group, especializada en marketing en línea y tecnología de medios de Internet. El informe denominado Æstado de Internet y comercio electrónico en Latinoamérica 2013"16, se centra en estudiar el consumo de Internet en países latinoamericanos.

- Brasil es el país que tiene más de 58 millones de cuentas de Facebook. En segundo puesto se ubica México superando los 38 millones y Argentina se encuentra en tercer lugar con 20 millones de cuentas.

- Latinoamérica es una de las regiones donde más se utilizan las redes sociales

- Se espera que el número de usuarios en redes sociales se duplique en el transcurso del año 2014.

\footnotetext{
${ }^{16}$ En http://www.slideshare.net/JosLuisValdivielso/informe-internet-y-comercio-electrnico-2013en-latinoamrica (Consultada: 30 julio 2014).
} 
Los trabajos citados no hacen más que ilustrar el crecimiento y el auge que vive Facebook, al igual que su permanencia y su contante transformación, sumando nuevas aplicaciones o reformando las existentes.

Las redes sociales, especialmente Facebook, son espacios en los que los usuarios recurren para informarse, conectarse y así poder expresarse con otros. La mayoría de los medios gráficos, radiales, televisivos, digitales poseen una cuenta en Facebook, a través de la cual informan y se comunican con sus audiencias de una forma rápida. De esta manera, la red social intenta proveer al usuario un escenario pertinente para satisfacer sus necesidades, convirtiéndolo en un lugar en el que el usuario pueda encontrar lo que está buscando, y que además se exprese cuando lo requiera.

Facebook dispone de una multiplataforma interactiva que atrae a los usuarios permanentemente. La popularidad que logró, posibilitó que esta red alcance un grado de difusión impredecible. Como afirma el Magister en Ciencias Sociales, Alejandro Piscitelli, en el Prólogo del libro Facebook es el mensaje. Oralidad escritura y después, escrito por Guadalupe López y Clara Ciuffoli, Consideramos a Facebook como un mutante digital porque (como muchas plataformas y servicios en Internet) está en permanente transformación. Surgió como una red social exclusiva y fue mutando hacia un entramado digital que integra en un mismo lugar una plataforma de publicación personal, con una gran variedad de herramientas y aplicaciones. Un espacio convergente que reúne contenidos de los más diversos en diferentes formatos, publicados por usuarios, medios de comunicación, celebrities, artistas, políticos, marcas, instituciones y organizaciones. Facebook es cada una de estas cosas, y todo a la vez (...)” (Piscitelli 2012: 9).

Facebook por sobre el resto de las redes sociales, es una herramienta de socialización, de comunicación pero también de información entre los usuarios. Reúne en su seno páginas personales, de fans, sitios oficiales de empresas, servicios, publicidades, comunidades en torno a un tema en particular, páginas oficiales de políticos y famosos. Esta red social aunó en una sola plataforma aplicaciones y prácticas que estaban dispersas en diferentes sitios de Internet. 
En el momento de definir a Facebook, considero que no es solamente una red social, sino que también es un medio de comunicación en sí mismo, es un espacio de comunicación en el que convergen medios tradicionales, los cuales se renuevan permanentemente, para seguir subsistiendo con el avance de la tecnología y la aparición de sucesivas plataformas digitales. Los protagonistas son los usuarios, que con su participación e intercambios de comentarios, posibilitan la interacción constante.

Un mismo producto televisivo como es una tira, luego de ser transmitido por la televisión, es subido a la página web del canal, y al Facebook oficial de dicha tira. La posibilidad de ver un mismo contenido en diferentes plataformas digitales, hace que estas se conviertan en un medio. La tecnología posibilitó que el usuario tome la decisión de cuándo, cómo y a través de que dispositivo pretende ver una ficción determinada.

Es Facebook la red social que logró integrar diferentes medios de comunicación en su interior, permitiendo además, posicionar a los usuarios, como los verdaderos protagonistas en el funcionamiento de una página. Porque de qué serviría crear una página de Facebook que no es comentada por nadie.

Una conceptualización interesante fue propuesta por el Doctor en Ciencias Sociales, Mario Carlón (2012) al definir a Facebook como una red de medios, en la que los usuarios desde que abren sus páginas personales se convierten en medios de comunicación, generando discursos en los cuales comunican sus acciones, pensamientos, se enteran de lo que sucede, entre otras cosas.

El investigador también define a Facebook como medio de medios, es decir que tiene el diseño de una página, contiene correos electrónicos, chat, fotografías, videos, entre otras; y esta es una de las razones por las que habilita distintas discursividades.

La transformación permanente de Facebook permitió que se convierta en otro medio o en un medio de medios. Un ejemplo serían los Facebooks oficiales de las tiras, a través del cual se pueden encontrar los capítulos anteriores, fotos, entrevistas, adelantos, además de 
escribir comentarios, iniciar debates e intercambios y compartir la información que nos interesa.

¿Cuál es el atractivo que tiene esta red?, ¿Por qué se mantiene vigente?, ¿Por qué mantiene a sus usuarios cautivos?, ¿Cuál es el motivo por el que convoca a más adeptos?, ¿Facebook es la madre de todas las redes sociales?.

Varios son los interrogantes que pueden surgir en torno a Facebook. Sin embargo, para poder ir desentrañando todas las inquietudes, primero es importante conocer los orígenes de esta red social, su crecimiento y consolidación. 


\section{INICIO}

En un contexto mediado por el desarrollo de las web 2.0, el auge de las primeras redes sociales que mantenían su liderazgo como My Space, al igual que los foros en torno a una temática en particular o los blogs personales, surge Facebook; reuniendo las principales características y funciones de esas plataformas. Convirtiéndose en un espacio multitareas y de fácil acceso.

Como afirman Danah Boyd y Nicole Ellison (2007), en el año 2003 se inicia una etapa importante en la evolución de las redes sociales debido a que el periodo se caracteriza por el surgimiento de servicios web en los que convergen características propias de las plataformas de publicación de contenidos online, como los blogs, con particularidades de los servicios de redes sociales, como poder compartir las publicaciones con otros usuarios amigos"

Con el propósito de comenzar a narrar los orígenes de Facebbok, nos debemos remontar al 4 de febrero del 2004, cuando un grupo de estudiantes de la Universidad de Hardvard, Mark Zuckerberg (fundador), Dustin Moskovitz, Chris Hughes y Eduardo Saverin (cofundadores), crearon una plataforma exclusiva para los estudiantes de dicha institución educativa denominada thefacebook.com. El motivo principal era poder compartir información y estar en contacto de manera online con personas que compartían el mismo círculo social, es decir el campo universitario. 


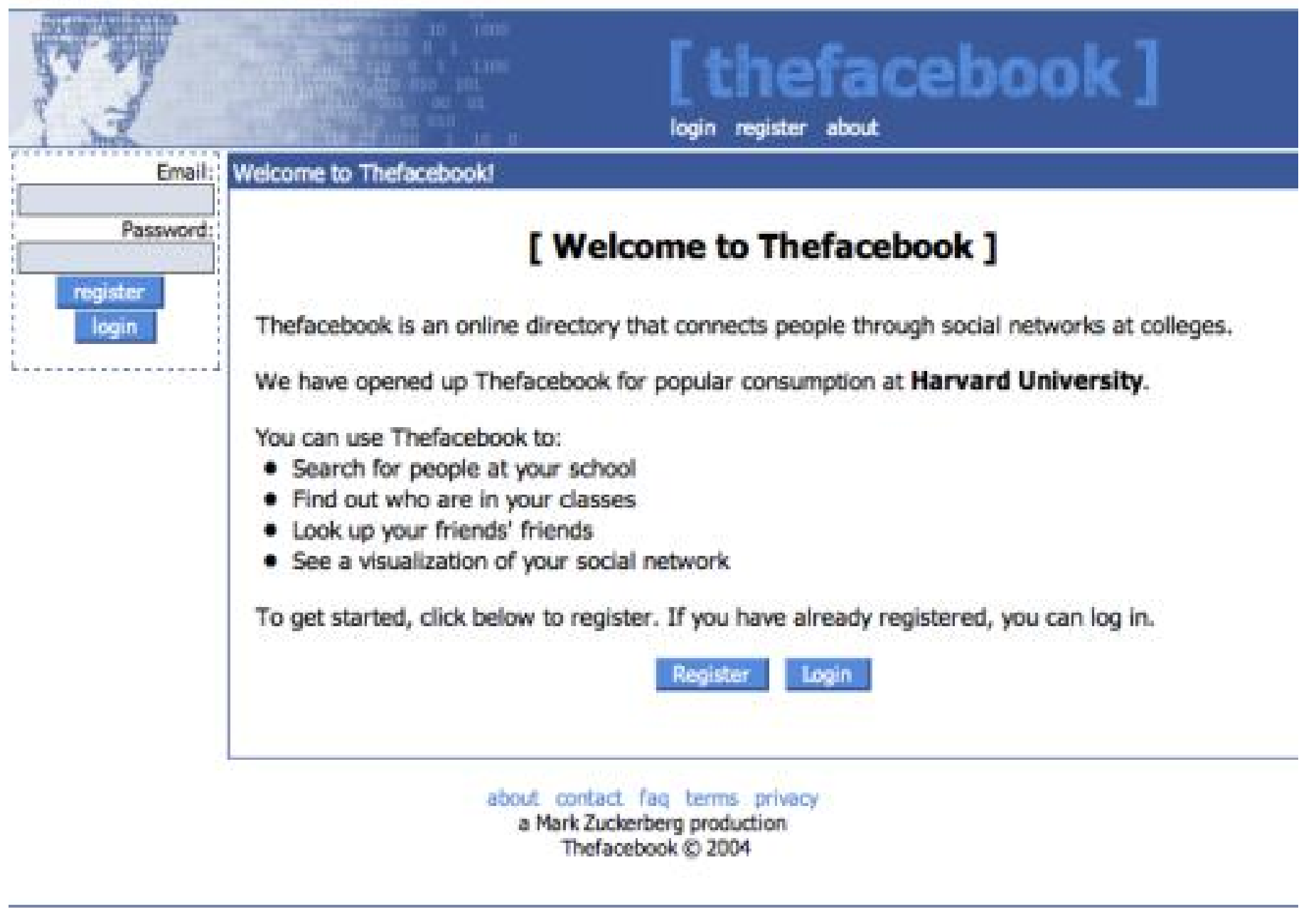

Imagen de la primera versión de la red social disponible para estudiantes de la Universidad de Hardvard. FUENTE: http://www.socialmedialife.it/wpcontent/uploads/2014/02/Thefacebook.png (Consultada: 1 agosto 2014). 
En sus comienzos fue denominado thefacebook, para uso exclusivo de alumnos de la Universidad de Hardvard. En la página de inicio se explica que es un directorio en línea que conecta gente de la universidad a través de las redes sociales y que fue abierto para el consumo popular en esa institución educativa. También se menciona las herramientas que propone: buscar personas en tu escuela, saber quién está en su clase, buscar amigos de tus amigos y poder visualizar tu propia red social.

La información ocupa la mayor parte de la página, y solo a un costado aparece una pequeña columna en la que se deben introducir los datos como el correo electrónico y la contraseña para registrarse e ingresar.

Presenta un diseño simple, que tiene como objetivo informar acerca de los diferentes usos que dispone la red social, la cual es exclusiva del ámbito universitario.

Ante los sucesivos pedidos de participación de estudiantes de otras universidades, Mark Zuckerberg decidió ampliar el acceso a otras universidades como Standford, Yale y Columbia. Luego, también tuvieron accesos diversas escuelas secundarias de Estados Unidos y de otros países.

En el mes de septiembre, apareció el llamado muro, en el cual los usuarios podían publicar mensajes a sus amigos. En diciembre del 2004, la red social llegó a tener un millón de usuarios.

En el año 2005 pasó a llamarse con el nombre que se lo conoce actualmente, Facebook. Progresivamente, aparecieron diferentes aplicaciones, como la posibilidad de subir fotos y también, compartirlas entre los amigos.

Recién en el año 2006 la plataforma permitió el acceso libre a cualquier persona, luego del registro a través del correo electrónico y una contraseña. Si bien se tenía 
conocimiento sobre Facebook, la posibilidad de ingresar y participar de él, permitió que se expanda la cantidad de usuarios, llegando a doce millones ${ }^{17}$.

La gran cantidad de suscriptos en el mundo, de amigos de amigos, permitió que Facebook aumentara la cantidad de usuarios. Los investigadores Carolina Gruffat y Roberto Schimkus explican que ła exhibición pública de las conexiones es un componente fundamental de las redes sociales. La lista de amigos" en Facebook contiene enlaces a los perfiles de cada amigo, donde se encuentran elementos con distintos niveles de privacidad, configurados por el usuario. Los enlaces de amistad" son bidireccionales - es decir, requieren ser confirmados por otro usuario-, aunque hay también enlaces unidireccionales en el caso de los fans" o -seguidores"” (Gruffat y Schimkus 2010: 74).

Por otra parte, el lanzamiento de Facebook para móviles - año 2007 -fue un factor importante para la compañía, debido a que gran cantidad de sus usuarios se pudieron conectar a la red social a través de diferentes aparatos electrónicos, como smarthphones, tablets.

Una aplicación revolucionaria que proporcionó Facebook es poder compartir e insertar contenidos de otros sitios como puede ser YouTube. Dicha función es un ejemplo de cómo esta red social es también una red de medios. La posibilidad de subir información de otros sitios convierte a Facebook en una plataforma en la que convergen múltiples medios de comunicación. Al mismo tiempo, integró el news feed y el mini feed, servicios a través de los cuales se crea automáticamente una micropublicación por cada acción que un usuario realiza en su perfil (mini feed), que a su vez se publica en la página principal de todos sus amigos (news feed), volviendo innecesario tener que entrar al perfil de cada contacto para conocer sus últimas publicaciones (...) Junto con estos cambios, la red incorporó el servicio de administración de las políticas de privacidad para cada usuario” (López y Ciuffoli 2012: 14).

Si faltaba una aplicación fundamental para convertir a Facebook en una plataforma multitareas, esto ocurrió en abril del año 2008, con la aparición el chat. Con esta iniciativa

${ }^{17}$ En https://newsroom.fb.com/Timeline 
Facebook lograba combinar diferentes aplicaciones, no solo la de publicar mensajes, subir fotos, videos, enlaces, sino que también permitía la comunicación en forma simultánea entre los usuarios.

\section{facebook}

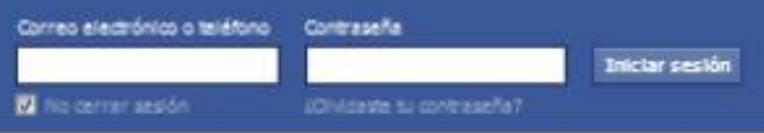

Facebook te ayuda a comunicarte y compartir con las personas que forman parte de tu vida.

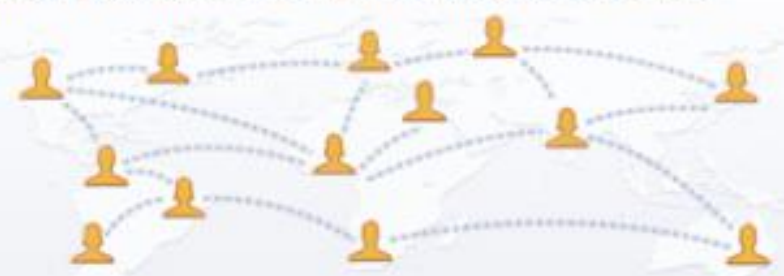

\section{Abre una cuenta}

\section{Es gratis y lo será siempre.}

\begin{tabular}{|l|}
\hline Nombre \\
\hline Tu correo electrónico \\
\hline Vuelve a escribir tu correo \\
\hline Contraseña \\
\hline
\end{tabular}

Fecha de nacimiento

Dis $\square$ Ne=

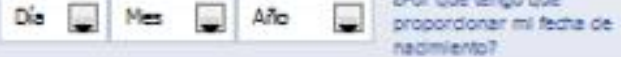

- Mujer Hombre

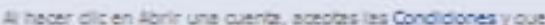

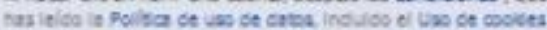

\section{Abrir una cuenta}

Crear una página para una celebridad, un grupo de músich e un negocio.

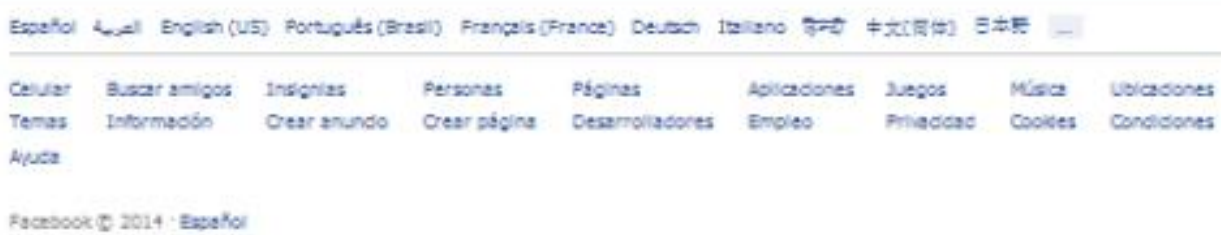

Imagen de Facebook en el año 2008 hasta la actualidad. FUENTE: https://www.facebook.com/?! s=c (Consultada: 1 agosto 2014). 
La página de inicio actual de Facebook presenta un slogan "Facebook te ayuda a comunicarte y compartir con las personas que forman parte de tu vida" sumado a una ilustración del planisferio, con distintas cabezas que representan a los usuarios en diferentes ubicaciones, y unidos por redes.

El mensaje que propone Facebook prioriza la comunicación y el poder compartir dentro del mundo en red. Por otra parte, la imagen pretende demostrar el alcance que tiene esta red social en todo el mundo, conectando personas de diferentes regiones. Además, invita al usuario a abrir una cuenta, aclarando que "es gratis y siempre lo será", intentando diferenciarse de otras redes sociales en las cuales hay que pagar para poder utilizarlas.

La novedad radica en ingresar la fecha de nacimiento, explicando que tiene como objetivo que el contenido que aparece en Facebook sea adecuado para tu edad. Este requisito forma parte de una política de seguridad por parte de la empresa. También se debe especificar el sexo.

Al mismo tiempo Facebook permite poder seleccionar tu idioma dentro del conjunto de lenguas. Registrarte con un correo electrónico y contraseña, y por último publicita algunas de las aplicaciones que dispone como juegos, búsqueda de persona, creación de anuncios, entre otras. 
A partir del año 2009 se incorpora la herramienta -me gusta". Uno de los elementos característicos de Facebook, que permite adherirse a una página, y manifestar si se está de acuerdo con determinada nota o comentario que se publicó.

La consolidación de Facebook le permitió crear alianzas con otras empresas. Como fue el caso en el año 2012, con el servicio de fotografía móvil Instagram, el cual permite compartir fotos, videos, en diversas redes sociales. Del mismo modo, en febrero del 2014 compró Whatsaap, una plataforma de mensajería instantánea global.

La iniciativa demuestra que Facebook antes que una red social, y un medio de comunicación es una empresa que funciona con las lógicas del mercado capitalista. No es inocente la unión de Facebook con Whatsapp (líder mundial en chat), hay intereses económicos que median dentro del mundo de la tecnología.

La convergencia tecnológica que se suscita posiciona Facebook como una compañía que intenta acaparar las plataformas más populares dentro de la industria digital, y que hasta el momento lo está consiguiendo. 


\section{ASPECTOS CLAVES}

Después de diez años Facebook no perdió su vigencia. El número de usuarios crece constantemente, y la red social elabora permanentemente estrategias (cambio de diseño, incorporación de juegos como Candy Crash, entre otras) para sumar adeptos.

A pesar de que Facebook no sea utilizado por toda la sociedad, las situaciones que se desarrollan en esta red social repercuten, y son tomadas por otros medios o simplemente por personas físicas que comentan algún hecho particular que esté ocurriendo en Facebook.

Facebook es la red social por excelencia, alcanzado una popularidad que produce que diversas situaciones que se generan dentro de Facebook influyan en los usuarios y también en personas ajenas a esta red social.

Si bien Facebook es una red social, trasciende esta categorización en varios aspectos. Uno de los motivos es que se convirtió en un medio de comunicación más; no solo porque es tomado por canales de televisión, radios, diarios, revistas para la difusión y tratamiento sino porque también es una plataforma que permite la consolidación de un producto determinado dentro del campo de la comunicación.

Facebook se incorporó a la vida cotidiana, está presente en los diferentes ámbitos en los que las personas participan. Las redes sociales forman parte del cotidiano, están latentes, a disposición del usuario; propiciando un escenario impensado tiempo pasado. Cuando las redes digitales de comunicación tejieron sus hilos alrededor del planeta, todo cambió raudamente, y el futuro aún promete otras metamorfosis. En los meandros de ese ciberespacio a escala global germinan nuevas prácticas difíciles de catalogar, inscriptas en el 
naciente ámbito de la comunicación mediada por computadora. Son rituales bastante variados, que brotan en todos los rincones del mundo y no cesan de ganar nuevos adeptos día tras días" (Sibilia 2008: 5).

La expansión de Facebook no tiene límites, a tal punto de convertirse en un medio de comunicación e información, en el que los usuarios no solamente participan y opinan, sino que adquirieron un rol tan activo, que les permitió jugar a ser coproductores de las tiras de televisión que se están emitiendo. Al demandar cambios en la trama, incorporación o eliminación de ciertos personajes, modificación de horarios.

Facebook plantea un nuevo modo de ver televisión, proponiendo una plataforma a través de la cual, los usuarios pueden mirar determinada tira, comentar, proponer cambios en el rumbo de la historia, publicar notas, videos, fotos, debatir, informarse; convirtiéndose de este modo en una plataforma integral. Sin embargo esto no significa que elimina a un medio tradicional como es la televisión, sino que ambos pueden convivir perfectamente, reconfigurándose y adaptándose dentro de la industria tecnológica.

En Facebook se puede encontrar un espacio para poder expresarse de manera colectiva en torno a una ficción, permitiendo que intervengan usuarios de otros países, que están mirando la misma tira a través de Internet, creando de esta forma un escenario multicultural interesante, acercando a los usuarios de diferentes países, y así poder constituir una comunidad que tiene intereses en común sobre una tira en particular.

La información en Facebook está en circulación permanente, se traslada por diferentes muros. Una vez que se comparte, o con el solo hecho de poner me gusta", una noticia se visibiliza en el muro de otros usuarios amigos. Tiene un principio, un origen pero no un final, está en constante movimiento.

Otro dato que considero importante de destacar, es que, Facebook permite no solamente distribuir contenidos, si no también generarlos, posibilitando al usuario una plataforma digital integral a través de la cual pueda crear sus propios proyectos, 
convirtiéndolos de este modo en emisores de contenidos. Como ejemplo, se puede mencionar a las narraciones transmediáticas.

Por último, Facebook es un medio de comunicación pero por ese motivo no deja de ser una red social. Ambas características pueden convivir sin ningún inconveniente, y son inherentes a cualquier usuario; quien además es responsable de encontrarle diferentes usos a Facebook, a partir de las herramientas digitales otorgadas. 


\section{CONVERGENCIA}

\section{MEDIATICA}

CAPITULO III 
En este capitulo se trabajará con el término convergencia mediática desde la perspectiva teórica desarrollada por Henry Jenkins, para lograr una comprensión del campo en donde conviven los medios de comunicación tradicionales y los llamados nuevos medios.

En la segunda parte del presente apartado, se analizará el funcionamiento de las narraciones trasmediáticas, no solamente desde la producción sino desde la circulación y el alcance que obtienen en los nuevos medios como las redes sociales, que son un canal para la difusión y consumo de este tipo de narraciones.

Este eje aportará conocimientos sobre cómo se conjugan los diversos medios, constituyéndose como hipermedios, así como también, el uso que las audiencias/usuarios hacen de estos espacios, creando sus propias producciones que funcionan como subficciones. Centralizándome en los procesos que surgen en un contexto mediado por la generación de medios digitales interactivos y la coexistencia con medios anteriores, fundando una resignificación constante sobre los usos de los medios de comunicación. 


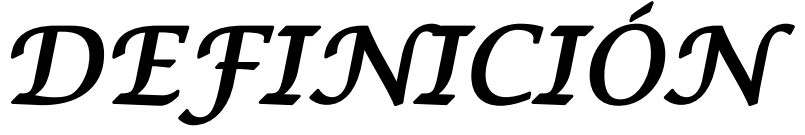

El mundo digital y los nuevos medios, como Facebook, convergen. El nuevo perfil del espectador multitarea se hace eco de los cambios sufridos por todas las partes que intervienen en la comunicación televisiva con la llegada de las redes sociales. Pero también como dice el Doctor Henry Jenkins (2008), está presente la lógica económica de una industria del entretenimiento horizontalmente integrada, es decir, donde una producción de una tira, puede extender sus raíces por todos los diferentes sectores mediáticos, dirigiendo el flujo de contenidos a través de los medios.

El concepto más apropiado para pensar este espacio es el de -envergencia", un término polisémico que durante mucho tiempo, especialmente en la década de 1990, fue asociado a la idea de convergencia tecnológica. La metáfora que circulaba por aquellos años era la de una eaja negra" que llegaría a integrar todas las funcionalidades de los medios existentes y por venir" (López y Ciuffoli 2012: 32).

Por su parte, Henry Jenkins, asocia la palabra convergencia a los cambios tecnológicos, industriales, culturales y sociales, y las nuevas relaciones que se tejen entre medios, audiencias y productos mediáticos en la sociedad contemporánea.

El término convergencia mediática torna inevitable el flujo de contenidos a través de múltiples plataformas mediáticas. Todo lo relativo a la estructura de la moderna industria del entretenimiento se diseñó con esta única idea en mente: la construcción y el fortalecimiento de las franquicias del entretenimiento. Existe un enorme interés por integrar el entretenimiento y el marketing, para crear fuertes vínculos emocionales y emplearlos para aumentar las ventas en ciertas empresas de entretenimiento.

Cuando el canal decide crear un Facebook oficial de una tira, promocionándolo en la Web del canal, alentando al permanente debate y participación de las audiencias; dicha empresa está creando un aparato poderoso, en el cual no solamente los medios se 
interrelacionan, sino que luchan por posicionarse como una gran maquinaria, en la que todos sus engranajes funcionan conjuntamente, para que a las audiencias no le falte nada, y que acudan a cualquiera de sus medios en el momento que les interese saber algún dato de la tira en cuestión.

Resulta obsoleto pensar que la tira crece y se fortalece únicamente por su trama o actores. Existe un mecanismo pensado por y para las audiencias, para atraerlas, seducirlas permanentemente, logrando que una determinada ficción funcione como un todo integrado, más allá de la transmisión diaria.

Un caso es la ficción argentina Aliados ${ }^{18}$, emitida por el Canal Telefe, durante el año 2013, y con una segunda temporada a partir del 2014. Destinada a un público juvenil, presenta una plataforma multifuncional. Cada capítulo se emite por televisión en forma de unitario, mientras que durante la semana, la página oficial ofrece webisodios (episodios por Internet), de siete minutos. También dispone de una actualización constante de las redes sociales oficiales. Además, presenta diversos contenidos para descargar a través de dispositivos móviles.

Aliados conjuga la construcción de una historia a través de diferentes medios y plataformas, con la consecuente participación de las audiencias / usuarios.

Página oficial: http://aliados.telefe.com/aliados/

18 Ficción argentina, producida por Cris Morena Group (Cris Morena). Comenzó a emitirse el miércoles 26 de junio de 2013 en el prime time de Telefe. Protagonistas: Juán Pedro Lanzani, Oriana Sabatini, Mariel Percossi, Agustín Bernasconi, Julián Serrano, .Joaquín Ochoa, Pablo Martínez, Jenny Martínez, Nicolás Francella, Lola Morán, Carolina Domenech y Máximo Espíndola. Guionista: Leandro Calderone. Directores: Carlos Luna, Diego Sánchez y Estela Cristián. La historia narra que la humanidad comenzó una cuenta regresiva que conducirá a su destrucción o a su renacimiento. Esta situación dependerá de de siete jóvenes humanos, habitados por siete seres de diferentes dimensiones, que se convertirán en sus aliados. 
La convergencia mediática se desarrolla en un contexto mediado por un interés económico donde las empresas televisivas junto con la industria digital realizan alianzas estratégicas que les permitan lograr un posicionamiento y liderazgo dentro de la industria del entretenimiento.

Como expone David Morley (2008) en su libro Medios, modernidad y tecnología: Hacia una teoría interdisciplinaria de la cultura, la fuerza impulsadora de la convergencia no radica en la demanda de los consumidores, sino en una combinación de los deseos conducidos por las industrias para poder maximizar las ganancias. Las estrategias comerciales suelen estar guiadas por la lógica de optimización del producto combinada con la maximización de las ganancias.

Por lo tanto, existe detrás un trasfondo económico, que se ubica en las convergencias mediáticas que se consideran rentables en el plano comercial, demostrando así, que estás convergencias no fueron realizadas de manera inocente, ni pensadas exclusivamente para mejorar el modo de consumo digital de los usuarios de una forma integral.

Otra reflexión pertinente sobre la convergencia mediática, es otorgada por el Doctor en Ciencias Sociales, Luis García Fanlo, quien a afirma que ta convergencia entre televisión, telefonía celular y plataforma web, en particular las redes sociales, aparece como condición de posibilidad para que la conjunción entre soporte tecnológico y prácticas sociales sirva como un espacio privilegiado para que se desarrollen y potencien estas luchas inmediatas, antiautoritarias y cuestionadoras de las formas disciplinarias de ejercicio del poder y que se caracterizaban por la imposición unilateral de los productores sobre los consumidores. El consumidor actual ya no acepta dócilmente los productos que se le ofrecen sino que reclama ser coproductor de su propio consumo (...)" (2012: 110).

A pesar del protagonismo que tienen las audiencias, al encontrar por ejemplo, en las redes sociales, un espacio en el que se permite el dialogo entre ellas, es necesario marcar ciertos límites, y ser conscientes que todo este escenario está mediado por la estructura de los canales y de las productoras de televisión. Esto significa que es difícil que obtengan el 
mismo poder que posee un productor, guionistas al tomar ciertas decisiones sobre la trama, la entrada o salida de algún personaje en particular, entre otras cuestiones.

Si existe a través de las redes sociales, el ámbito propicio para que las audiencias expresen sus opiniones sobre ciertos rumbos del argumento. Un ejemplo es la tira Farsantes, en la cual mataron al personaje de Pedro, disolviendo de esta manera a la pareja protagónica de la ficción. Esta situación provocó el descontentó de los fanáticos al enterarse de la eliminación del personaje, quienes no tardaron en expresar su rechazo a través de las redes sociales.

San-ti Dias > Farsantes - Página oficial

30 de septiembre de 2013

Qué desillucion esta noticia sobre benjamin ...no nos pueden hacer esto a los seguidores de farsantes ..creo qué nuestra opinión nos les importa a ellos, qué mal che

Me gusta - Comentar

A 7 personas les gusta esto.

Ex

Myriam Carrillo Pero somos nosotros los q llevamos esta tira al maximo rating... ojala se den cuenta y reviertan todo lo se dice

1 de octubre de 2013 a la(s) 0:38 * Me gusta

Eushii Cáceres tal vez al bajar el rating, y vean que es algo que en verdad nos importa hagan algo y lo pongan de nueva antes de su "muerte"

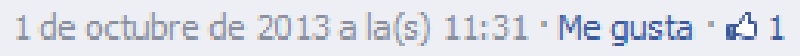


Hebe Lopez > Farsantes - Página oficial

30 de septiembre de 2013 cerca de Mar del Plata

la verdad es que estoy re mal lei en twuiter que vicuña deja farsantes yo no lo creo decian lo mismo en julio y aca esta diganme algun consuelo no lo puedo creer

Me gusta - Comentar

Viviana Monduzzi $>$ Farsantes - Página oficial

30 de septiembre de 2013 Q

\#PedroNoSeVa

Me gusta * Comentar

攰 4

Norma Beatriz Castillo $>$ Farsantes - Página oficial

31 de octubre de 2013

Por última vez no maten a Pedro es el amor soñado de Guillermo y no queremos que termine en un asesinato y somos muchas que juramos no ver la tira. Ya se que está filmado el final de Pedro pero también sé que lo pueden cambiar

Me gusta - Comentar

a 3 personas les gusta esto.

Cristal Mendoza benja esta intalado en chile

31 de octubre de 2013 a la(s) 23:15 * Me gusta

7 Lula Mi Mirando el capitulo muy tristemente...

31 de octubre de 2013 a la(s) 23:16 * Me gusta ' $\$ 2$ 
Una pequeña muestra de los numerosos mensajes que se publicaron en las redes sociales, demuestran como los usuarios a partir del giro de la trama que no los convencía, se nuclean, alzan sus voces, solicitando ser escuchados por los creadores de la tira. Esta forma de expresión sirvió para dar a conocer el enojo sobre el transcurso de la trama, lo que no significa que fuese la causa principal de la vuelta del personaje a la tira.

Ea cultura de la convergencia donde chocan los viejos y los nuevos medios, donde los medios populares se entrecruzan con los corporativos, donde el poder del productor y el consumidor mediáticos interaccionan de maneras impredecibles (...) Con convergencia me refiero al flujo de contenido a través de múltiples plataformas mediáticas, la cooperación entre múltiples industrias mediáticas y el comportamiento migratorio de las audiencias mediáticas, dispuestas a ir casi a cualquier parte en busca del tipo deseado de experiencias de entretenimiento. Convergencia es una palabra que logra describir los cambios tecnológicos, industriales, culturales y sociales en función de quienes hablen y de aquello a lo que crean estar refiriéndose". (Jenkins 2008: 14).

Como afirma Henry Jenkins, la convergencia mediática no se da solamente en los aparatos tecnológicos, se produce en el cerebro de los consumidores individuales y mediante sus interacciones sociales con otros, a partir de fragmentos de información extraídos del flujo mediático

La convergencia mediática pone en juego las nuevas tecnologías, con los medios tradicionales como la televisión. Todos coexisten y son utilizados por las audiencias, quienes hacen uso constante de los diferentes medios de acuerdo a sus necesidades.

Considero necesario retomar a David Morley (2008) debido a que aclara, que a pesar de abordar el significado contemporáneo de una gama más amplias de tecnologías de la comunicación, más allá de la televisión, no debemos dejarnos deslumbrar por la tecnología y colocarla en el centro de cualquier estudio, sino que, debemos comprender la variedad de 
maneras en que los medios nuevos y los antiguos se adaptan unos a otros y conviven en formas simbióticas y también cómo vivimos con ellos.

Con la tira argentina Dulce Amor se puede visualizar que a pesar de la existencia y uso de las redes sociales, y del uso de la tecnología en las diversas aplicaciones digitales que se suscitaron, enunciadas anteriormente, se decidió por optar, al finalizar la ficción, la edición de una fotonovela sobre la historia completa de la tira en formato de libro. Demostrando de esta manera, que pueden coexistir diversas herramientas, tradicionales y actuales, mediadas o no por la tecnología, a partir de una misma ficción.

Efectivamente, la convergencia mediática provoca que las audiencias consuman de diferentes modos la ficción que están mirando. Debatiendo, seleccionando qué parte de la tira pueden volver a ver, cuándo y las veces que deseen. En donde el modelo de televisión broadcasting (programación fija) se adapta a los nuevos medios como lo es la red social Facebook.

En la convergencia mediática subyacen los medios de comunicación tradicionales, las nuevas tecnologías, las redes sociales, creando un espacio propicio para la interacción de las audiencias, que reclaman, opinan, debaten, valoran, es decir, que interpelan continuamente lo que les proveen los canales de televisión. En el proceso de la convergencia, todos los medios mutan permanentemente, alterando sus relaciones con las tecnologías, las redes sociales, las audiencias, profundizando el modo de recepción colectiva.

La existencia de una convergencia que reúne a todos los medios de comunicación, con múltiples aplicaciones, acceso a diversas redes de información, creación y producción conjunta de contenidos; permite que las audiencias se conviertan en un sujeto activo de convergencia entre numerosos medios de comunicación. 


\section{HIPERMEDIACIONES}

Otro estudio reciente en el campo de la comunicación, desarrolla una teoría de la comunicación digital interactiva, que analiza las hipermediaciones, propuestas por el Doctor Carlos Scolari.

El autor se refiere a la aparición de una nueva generación de medios digitales interactivos, ya no basados en la lógica del broadcasting sino en un modelo comunicacional totalmente innovador, fundado en las redes y la colaboración de los usuarios.

Scolari (2009) afirma que la hipermediación es un proceso de intercambio, producción y consumo simbólico que se desarrolla en un entorno caracterizado por una gran cantidad de sujetos, medios y lenguajes interconectados tecnológicamente de manera reticular entre sí, siendo Internet un hipermedio. Los procesos de hipermediación nacen en el espacio virtual pero sus efectos van mucho más allá.

Las hipermediaciones se caracterizan por generar metaproductos que combinan los lenguajes y medios tradicionales dentro de un formato interactivo, siendo la convergencia de diferentes lenguajes y medios en un único entorno. La digitalización favorece la integración de las pantallas del celular, televisor, computadora, al permitir que un mismo contenido multimedia pueda aparecer en formatos diferentes, en cualquiera de ellas.

Scolari señala la importancia de pasar del análisis de los nuevos medios digitales (los objetos) al de las hipermediaciones (los procesos). Más allá de los productos tecnológicos, es necesario estudiar cómo se desarrollan dichos procesos, cuál es el curso que toman.

En este contexto, es preciso reproducir la pregunta que realizó Guillermo Orozco Gómez (2011), ¿Cómo comprender a las audiencias desde su nueva faceta de productores, y aun destructores de lo producido? El desafío que plantea no es solo su nominación, sobre la 
cual aún no hay acuerdo, aunque la que se va imponiendo es la de usuario, sino la comprensión de las múltiples interacciones con las múltiples pantallas, el descentramiento espacio-temporal de la interacción, la constitución de múltiples comunidades de recepción, producción, apropiación e interpretación.

Las convergencias y las interactividades posibles a partir de los dispositivos audiovisuales del ecosistema comunicativo contemporáneo han inaugurado algunas formas de interacción con los productos mediáticos. Sobre todo en el ámbito de la fícción, los fuevos fans" y otros usuarios hiperactivos empiezan a jugar el papel de creadores, pero inconformes, que trasciende el aún incomprendido rol de mero usuario, para convertirse en retadores, detractores o usurpadores de narrativas especificas, recreando así una ficción transmedial e inédita.

Nos ubicamos frente a una etapa compleja frente a la resignificación constante de los medios, y de la relación entre los medios y las audiencias/usuarios, término fundamental para describir el rol multifacético que presentan en la actualidad. Aparecen nuevas maneras que producen cambios en la forma de producir, distribuir y consumir contenidos.

Scolari afirma el tránsito de audiencias a usuarios, si bien en la era digital, estas se convirtieron en usuarios, esto no significa que dejaron de ser audiencias. Un término acertado sería audiencias/usuarios para nuclear a ambas, debido a que pueden coexistir perfectamente.

El lugar que consiguieron ocupar las audiencias/usuarios no significa que desestabilizará la hegemonía de empresas televisivas, sin embargo, las ubica en un lugar de interpelación permanente, de cambios profundos que deben atender a las exigencias de las audiencias/usuarios. Formamos parte de la transición hacia una nueva era mediática, y frente a este escenario se evidencia un replanteamiento sobre la naturaleza de los negocios de las industrias de contenidos y del entretenimiento. 


\section{NARRACIÓN TRANSMMEDIÁTICA}

El termino narración transmediatica fue introducido por Henry Jenkins, siendo retomado en la presente investigación, al permitir hacer referencia a una historia que se desarrolla a través de múltiples plataformas mediáticas, y en la que cada texto nuevo hace una contribución a la totalidad. En la narración trasmediática, cada medio es dependiente del otro y lo que se difunde en la televisión es presentado, por ejemplo en Facebook, de diversas formas. El recorrido por diferentes medios puede llegar a otorgar una experiencia y conocimientos que estimulan el consumo.

Ea narración trasmediática se refiere a una nueva estética que ha surgido en respuesta a la convergencia de los medios, que plantea nuevas exigencias a los consumidores y depende de la participación activa de las comunidades de conocimiento. La narración trasmediática es el arte de crear mundos. Para experimentar plenamente cualquier mundo de ficción, los consumidores deben asumir el papel de cazadores y recolectores, persiguiendo fragmentos de la historia a través de los canales mediáticos, intercambiando impresiones con los demás mediante grupos de discusión virtual, y colaborando para garantizar que todo aquel que invierta tiempo y esfuerzo logre una experiencia de entretenimiento más rica". (Jenkins 2008: 31).

La interconexión que produce este tipo de narración permite que los fans se involucren con la ficción y que pretendan hacer una subficción, tomando los personajes principales, las características fundamentales de la trama, pero con su propia narración, con su sello personal.

Son tantos los sentidos, las significaciones que circulan en el universo de las narraciones trasmediáticas, que permiten la creación de numerosos productos. 
Los videos musicales que realizaron los fans de la tira Farsantes son un ejemplo de narraciones trasmediáticas. La utilización de diferentes escenas de la ficción, editadas con una canción significativa que acompaña las imágenes y luego subidas a Youtube, también son una forma de relato.


Soy lo prohibido.Pedro e Guillermo.
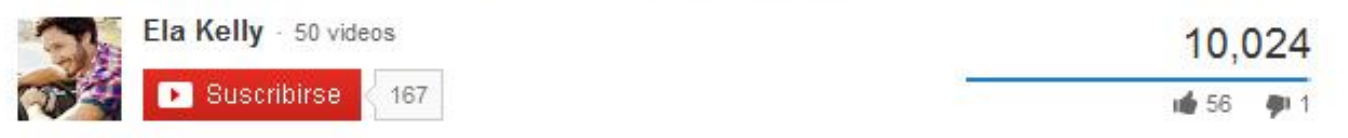

https://www.youtube.com/watch?v=oDVcbDrrBAo 


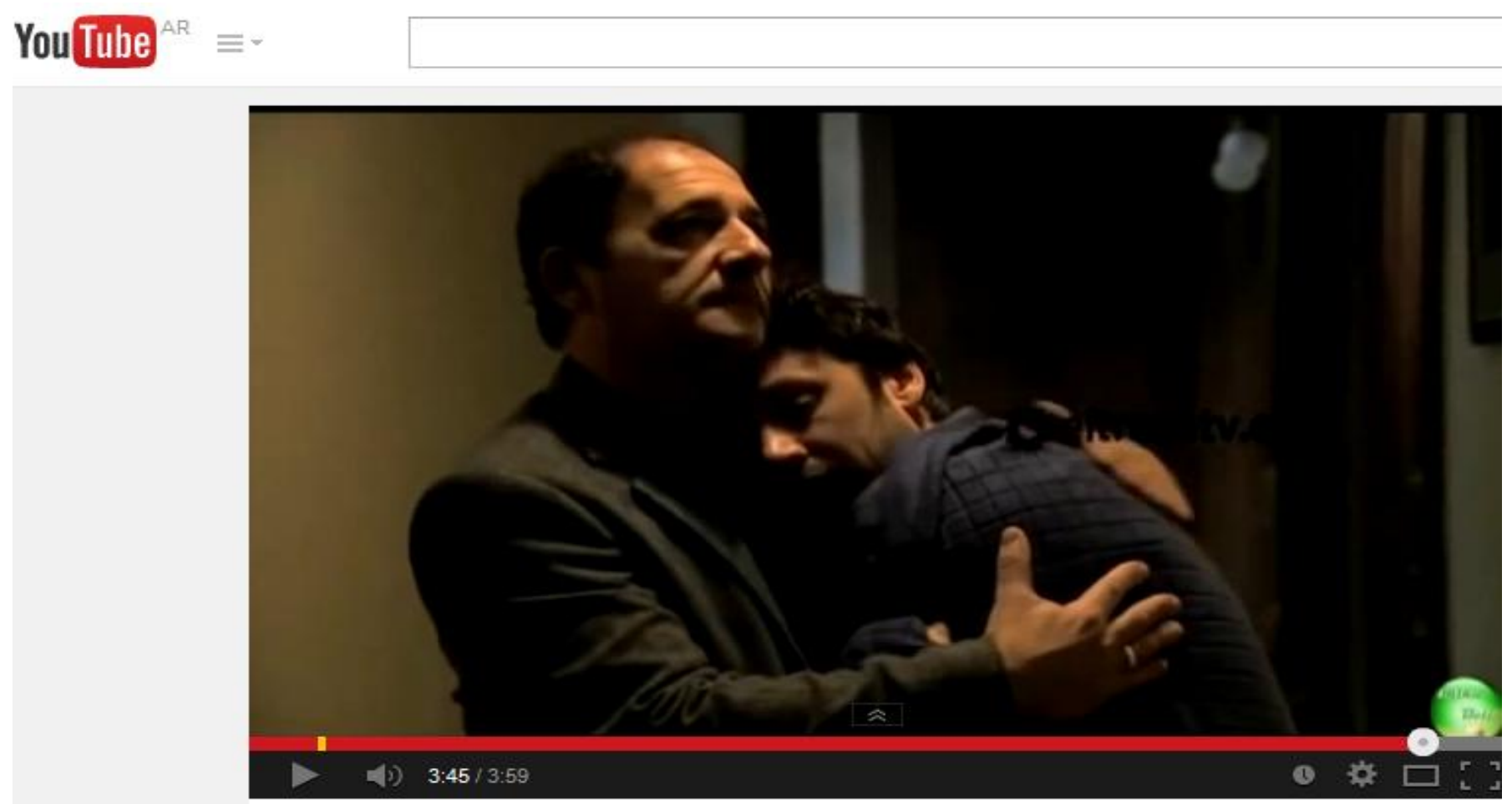

Guillermo y Pedro - Farsantes - Amor del Bueno

Diane Rush - 10 videos
D Suscribirse
85

$\frac{17,766}{71.5}$

https://www.youtube.com/watch?v=qr4LFDszP14 
Los fanáticos de la pareja de la tira Farsantes demuestran como seleccionan determinadas escenas significativas para ellos, junto con una música y una letra representativa o descriptiva de la historia de la pareja. A pesar de que el usuario crea el video musical con escenas extraídas de la tira, le está colocando su impronta, sus sentidos, lo que significan esos personajes para él.

Lo novedoso radica en la circulación y en el alcance que tienen estas narraciones a partir del avance de la tecnología y la consecuente creación de nuevos medios, que permiten alojar y promocionar estos productos.

No solamente el eje está en la producción y el diseño de determinado contenido, sino en las nuevas tendencias en la distribución, comercialización y acceso a las narraciones, provocando una transformación mediada por los cambios tecnológicos y las nuevas formas de consumir medios.

Continuando con este trayecto teórico, Orozco Gómez describe que ta convergencia tecnológica y la globalización de la cultura están propiciando la combinación de uno o más medios de comunicación en procesos inter o transmediales; estos cambios principalmente se caracterizan por la capacidad narrativa de crear o expandir comercialmente diversos productos en múltiples plataformas (...) Las posibilidades que brinda Internet, dentro de la convergencia, potencializa a los medios tradicionales y los sitúa ante nuevas posibilidades de interacción frente a las pantallas, pues las narrativas transmediáticas crean un -sensorio envolvente" que permite al comunicante trasladar o expandir sus gustos ficcionales a múltiples plataformas que le brindan diversas experiencias sensoriales por la simple materialidad del medio" (Orozco Gómez 2011: 394). 
Las audiencias / usuarios crean sus propias narraciones trasmediáticas haciendo uso de las herramientas que le provee la industria televisiva y las nuevas tecnologías. Tienen la posibilidad de armar la historia que desean, con los personajes que les interesan. Es tal la magnitud de este fenómeno, que los canales de tv deben actualizarse permanentemente, en busca de atraer la atención y participación de las audiencias / usuarios.

Dentro de este marco teórico, Jesús Martín Barbero (2011) explicita que transmedialidad y convergencia remiten a nuevos procesos y prácticas. Se desarrolla un novedoso modo de interacción entre medios, géneros y formatos. La transmedialidad produce una convergencia de innovación e incluso de invención que hace nacer a la vez nuevas cosas y nuevos usuarios.

Las narraciones transmediáticas permiten que la creatividad de las audiencias/ usuarios se expanda sin límites. En ese contexto, son ellos los autores y productores de lo que desean visualizar en la pantalla, y alojarlos en diferentes medios para que puedan circular y de este modo ser compartidos por otros.

Henry Jenkins propone siete principios fundamentales que caracterizan a las narraciones transmediáticas:

- Expansión vs. Profundidad: La expansión hace referencia al crecimiento de una narrativa a través de prácticas en las redes sociales, aumentado de esa manera el capital simbólico y económico del relato. La profundidad se refiere a la tarea que se tiene que llevar a cabo para encontrar a los verdaderos seguidores de una historia, aquellos que difundirán y ampliarán el universo inicial con sus propias producciones. Son estos fanáticos los que desarrollan un consumo forense" que desmonta y analiza cada capítulo hasta sacarle la última gota de jugo interpretativo. 
- Continuidad vs. Multiplicidad: los mundos narrativos transmediáticos necesitan tener una cierta continuidad o coherencia a través de los diferentes lenguajes, medios y plataformas en que se expresan. Y esta continuidad se complementa con la multiplicidad, es decir, la creación de experiencias narrativas aparentemente incoherentes respecto al mundo narrativo original.

- Inmersión vs. Extrabilidad: desde el cine hasta los videojuegos se caracterizan por proponer experiencias de inmersión. Por su parte, el proceso de extrabilidad; se desarrolla correctamente el mercado de los gadgets (juguetes, disfraces, etc.) debido a que permite extraer elementos del relato y llevarlos al mundo cotidiano.

- Construcción de mundos: las narrativas transmediáticas construyen mundos narrativos que deben ser en muchos aspectos fieles al concepto original. Los detalles significativos son los que conceden verosimilitud a la historia y forman parte del conocimiento de los fans.

- Serialidad: las piezas y fragmentos narrativos no se organizan en una serie lineal sino que se dispersan en una amplia trama que abarca muchos medios.

- Subjetividad: las narrativas transmediáticas privilegian formas del relato caracterizadas por subjetividades múltiples donde se cruzan muchas miradas, perspectivas $\mathrm{y}$ voces. Tienden a crear y potenciar determinados personajes $\mathrm{y}$ situaciones. 
- Realización: Los fans son prosumidores (Productor + consumidor) al producir nuevas historias y subirlas a la red. Caracterizando de esta forma, el rol activo que tiene el usuario para expandir la historia original. ${ }^{19}$

Las narraciones transmediáticas posibilitan la creación de un mundo virtual paralelo en el que convergen personajes e historias, pero que a la vez crea nuevos relatos que se desprenden de los intereses, gustos y creatividad de las audiencias/usuarios.

Resulta interesante destacar cómo a través de un producto televisivo, como es una tira, se puede dar lugar a diversas producciones escritas publicadas en redes sociales, blogs, permitiendo un intercambio entre las audiencias/usuarios.

Cuando finalizó la tira Dulce Amor, algunos fanáticos de la pareja principal, Victoria y Marcos, crearon blogs, en las que se escribian nuevos capitulos a partir del desenlace de la tira, es decir cómo continuaba la vida de casados, con dos hijos. Es interesante destacar la cantidad de escenas románticas entre ellos, debido a la inconformidad permanente de los fans por la escasez de ese tipo de escenas, que eran esperadas con ansias.

De este modo se desarrolla el después de la pareja, lo que habitualmente en las tiras ocurre en el último capitulo, dejando a la libre imaginación el futuro que les espera, este es retomado por las fans para continuar con el argumento, a su manera.

El blog denominado "Marcoria por siempre" ${ }^{20}$ también disponía de enlaces en Twitter y Facebook para publicitar la entrega de nuevos capitulos, que eran recibidos por los otros fans, quienes solicitaban nuevos capitulos.

19 En http://hipermediaciones.com/2010/02/04/narrativas-transmediaticas-novedades-del-frentecross-media/?relatedposts hit $=1$ \&relatedposts origin $=637$ \& relatedposts position $=1$ (Consultada: 6 agosto 2014).

20 Marcoria es un término que crearon las fanáticas a partir de la unión de los nombres de los personajes protagónicos, Marcos y Victoria, a través de las redes sociales. La tira lideró su franja horaria del prime time de Telefe, provocando una numerosa cantidad de seguidores que hasta se 
Resulta sorpresivo que si bien la tira finalizó el 29 de abril de 2013, a la fecha (agosto de 2014), a más de un año de haber finalizado, continúen creándose nuevos capítulos de esta subficción.

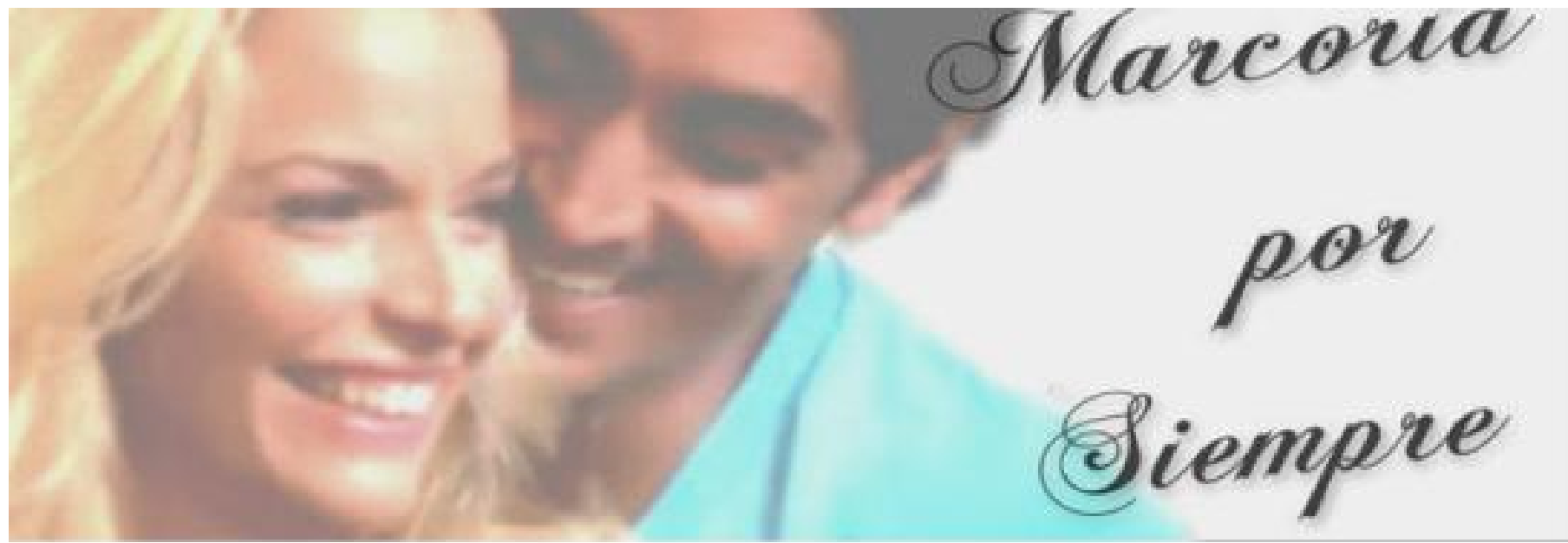

\section{OnWTrea}

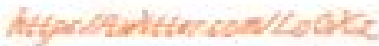

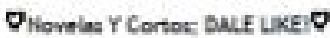

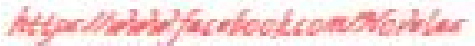

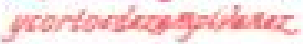

\section{$0 \operatorname{sis} \times 0$}

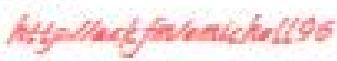

000

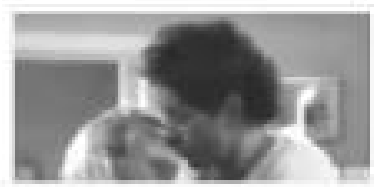

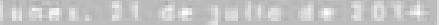

\section{CAP 87}

\section{IAarcos/}

Iuego de un rato de estar moviendo una Barbio an una boda imaginaria gue Emma habi iaventado. recogilas codo y la acostamos.

Pictaria y po nos acostamos a cada lado de ella y amparamos a lear uno de sus libros favoritos, cada uno led una pífia.

Ho mucho despus de enpezar el libro. bajela vista $y$ ancontróa Emma ya adarilada. Su boguita se abxidian un bostezo cuando apopola cabeza an il pacbo. luegra de gue se durmíá

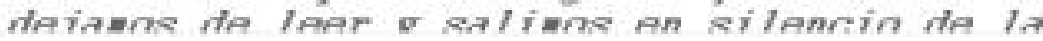

http://marcoriafdm.blogspot.com.ar/ (Consultada: 7 agosto 2014).

unían en el Obelisco (lugar emblemático de la Capital Federal) para reclamar por la reconciliación y posterior unión de la pareja, debido a que hacía muchos capítulos que estaban separados. 
Otro blog creado, es denominado Amor sin Etiquetas, continuando con la misma línea que el blog anterior, cómo siguió la vida de la pareja protagónica después del final televisivo.

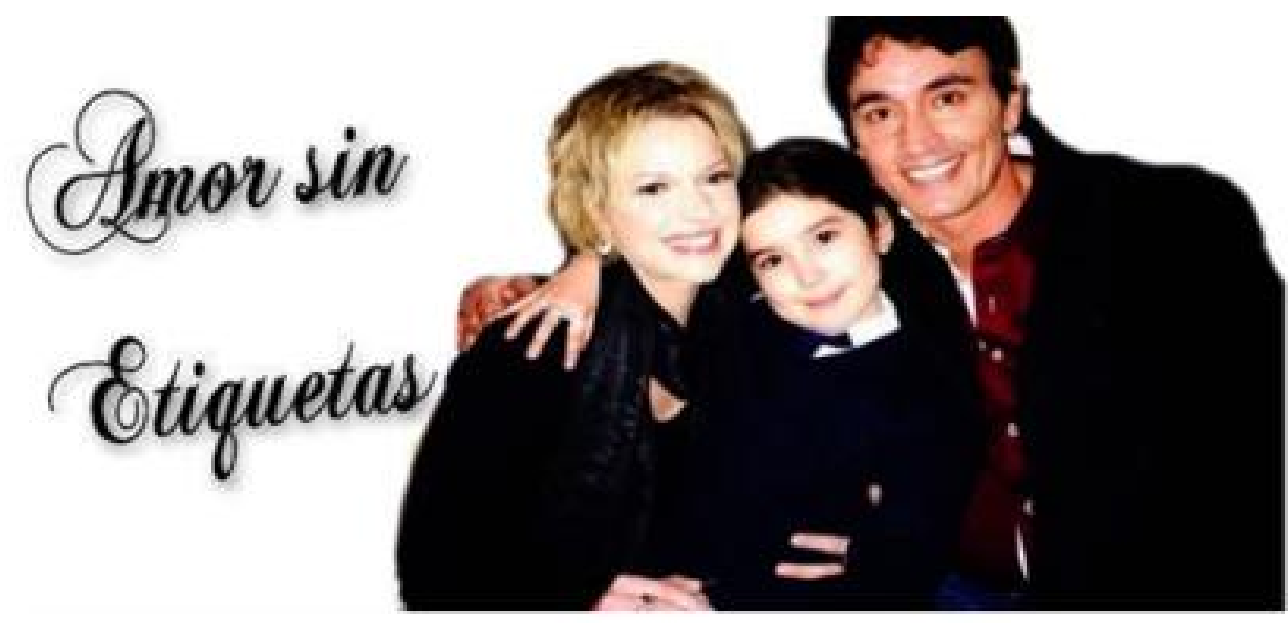

\section{miércoles, 23 de julio de 2014}

\section{'Fmor sin etiqueles" XIV}

-victoria*. Después del mal momento vílido en la fiesta, como siempre me encontraba frente a. Marcos riéndome a carcajadas, Su sentido del humor sin duda es una de las cosas que más me gusta de él. Nos encontrábamos sentados tal y como el mi había propuesto, en ropa interior comiendo el mejor sushi que jamás habia probado junto a un par de cervezas. Si, me sentia una adolescente, una adolescente completamente enamtorada de el hombre que tenia en frente. Al no poder concretar el tener relaciones nos llevo a hablar sobre el tema, cosa que funto a él no ena un tema vergonzoso para hablar, él me confesso que no queria mass hijos, al principio por alguna razón senti tun vacio en el estómago ya que yo st los queria, pero después de escuchar sus razones pude entenderlo perfectamente, y al pensarlo muy bien llegue a la conclusión de que yo al estar con eil" podía considerar a Emfly como una hifa, no?... I gualficeron pensamientos mios, no qufero que él piense que estoy llevando las cosas muy seriamente aunque confieso que asílo estaba haciendo, digo, ya no estoy en la edad de cambiar de pareja cada tanto, - \&? Me vas a dectr cuantos novtos tuviste? (Me pregunta Marcos apartindome de mis persamientos. mientras llevaba un rollito de sushi a mi boca) - (sonrió acepto el bocado y respondo) no
Páginas

- Novelas sk Cortos Dale LIKE

- Twritter.

- Ask

Vistas a la página totales

\section{7,682}

Archivo del Blog

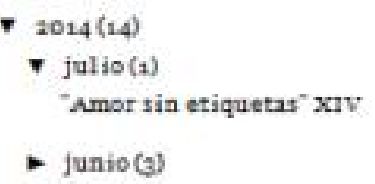

http://amorsinetiquetasmyv.blogspot.com.ar/ (Consultada: 7 agosto 2014). 
El vínculo entre algunas fanáticas no se perdió, y sigue subsistiendo a través de las redes sociales, desde las cuales se invita a leer la continuación de la historia creada por ellas mismas en diferentes blogs.

Al ser inimaginables la variedad de narraciones transmediaticas que pueden surgir a partir de una ficción determinada, en algunos casos se mezcla la realidad con la ficción, y se hace dificultoso distinguir los limites.

A partir de Dulce Amor, también se crearon historias en paralelo, pero con los actores que conformaron la pareja central, Carina Zampini y Sebastián Estevanez, es decir que se creó un universo en el que se describía y se escribían capítulos sobre lo que sería la vida de ellos dos como pareja. 

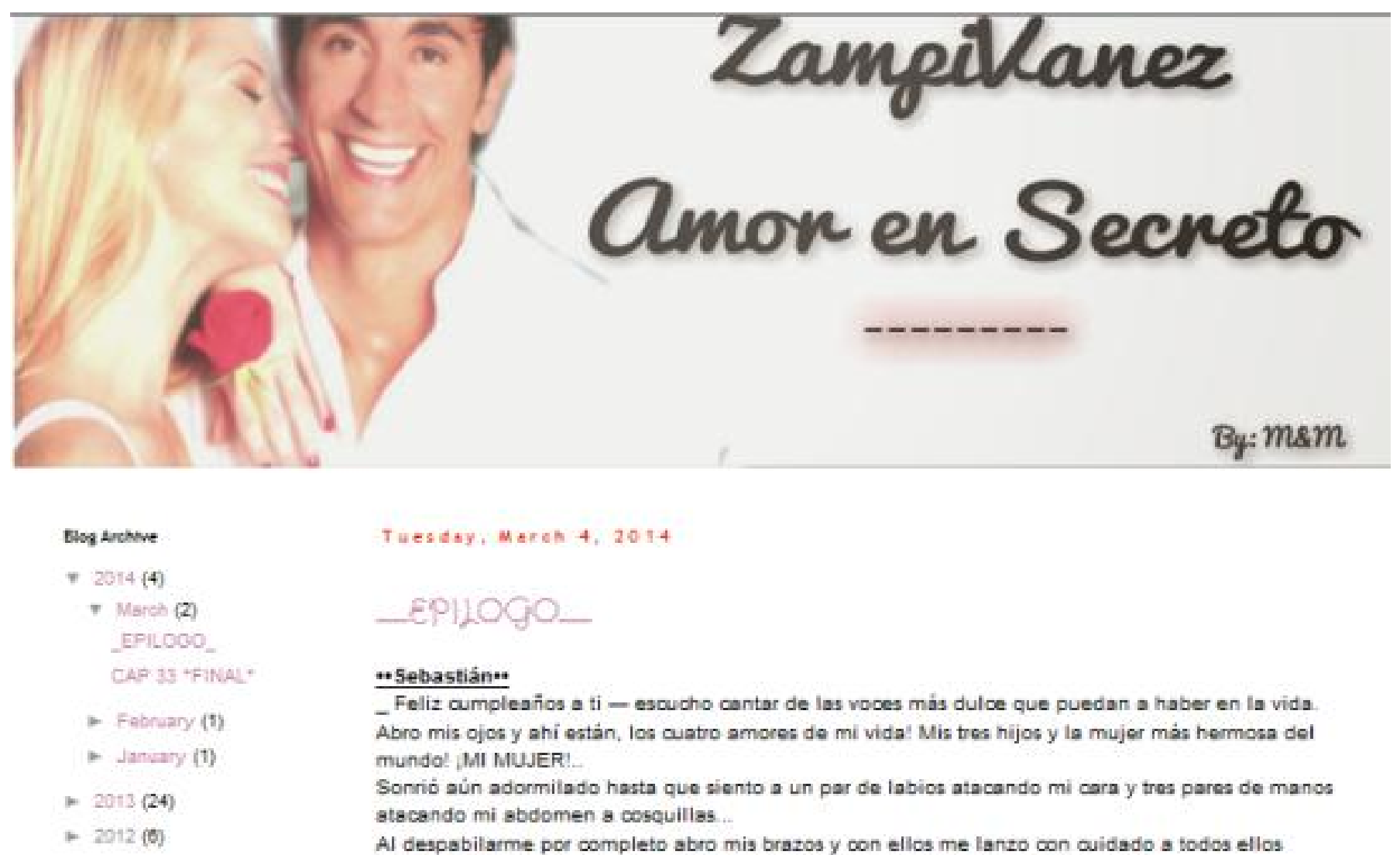

http://zampivanesamorensecreto.blogspot.com.ar/ (Consultada: 7 agosto 2014). 
miércoles, 23 de julio de 2014

\section{Capitulo 18+ Amigas Desconocidas •}

El sábado por la noche sebastian habia hecho todo lo imaginable para no pensar en carina. Pero acababa siempre recordando la suavidad de su piel como si la estuviese tocando en ese mismo instante, $Y$ terminaba frustrado imaginándosela con Joe. Êl podia tocarla y no era lasefvo. Él podia besarla y no era inmoral. Él podia.... que ni se le ocurriese hacer nada más porque lo mataria en ese instante, pensó sebas.

"Ti no tienes ninguin derecho sobre ella", le dijo una estúpida vocecita que se habia alojado en su cerebro después de la pasada noche.

Tenia todos los derechos porque ell la... no fue capaz de seguir con el pensamiento. La queria mucho, siempre la habia querido y siempre la querría. Pero no la amaba. No en el sentido pasional, Bueno si la deseaba, pero ise le pasaria' $Y$ después ¿qué? ¿Destrozar una relación tan perfecta solo para un polvo nápido? iNo! Le dolia el corazón solo pensar en perderla. Además, si él se atreviese a intentar algo con ella ena bastante probable que ella le diese una paliza por solo acercársele con esa intención.

Sonrió sin diversión. Carina era ese chico que hay en todas los grupos al que acuden los más débiles para que lo protejan. No es que fuese muy fuerts fisicamente, pero tenía conaje. Le daba igual el tamaño de su adversario, si se metian con uno de los suyos, ella atacaria. No pudo evitar acondarse del día en el que un grupo de cinco chicos lo habian acorralado y le estaban pegando cuando ella llegó y comenzó a lanzar patadas y puñetazos en rodas direcciones. Habia acabado con el labio roto y cientos de momatones; pero ellos no habian acabado mucho mejor. Era bueno para la salud de cualquiera no enfadarla. Puede que ya no utilizara los mismos métodos pero seguía siendo la misma

\section{Páginas}

- Novelas a Cortos Dale Lna

- Twitter.

- Ask

Vistas a la página totales

\section{6,807}

\section{Archivo del Blog}

V 2014(10)

> julio(1) Capitulo 18 • Amigos Desconocidos. •

- junio(3)

- abril (2)

- febrero (2)

- enero (2)

- $2013(9)$

http://novelaadaptadazye.blogspot.com.ar/ (Consultada: 7 agosto 2014). 
Con estas narraciones se constituyó una comunidad de fanáticas de esa tira, quienes disponen en Facebook una página en la que se aúnan para comentar, solicitar nuevos capítulos, y de esta manera hacer circular sus producciones ${ }^{21}$.

Ante el crecimiento de este fenómeno, las grandes industrias del medio no están ajenas, sino que intentan, desde su lugar, potenciar la actividad de los fans de una ficción. tos medios corporativos reconocen progresivamente el valor y la amenaza que representa la participación de los fans. Los productores y anunciantes mediáticos hablan hoy de -eapital emocional" o de -marcas de amor" para referirse a la importancia de la implicación y participación del público en los contenidos mediáticos. Los contadores de historias conciben hoy la narración como creación de espacios para la participación del consumidor. AI mismo tiempo, los consumidores emplean las nuevas tecnologías mediáticas para involucrarse en el contenido de los viejos medios, y ven Internet como un vehículo para la resolución colectiva de problemas, la deliberación pública y la creatividad popular. De hecho, la interacción y la tensión entre la fuerza de arriba abajo de la convergencia corporativa y la fuerza de abajo arriba de la convergencia popular la que está impulsando muchos de los cambios que observamos en el paisaje mediático" (Jenkins 2008: 174).

La lucha permanente que emprenden audiencias/usuarios para innovar y atraer a otros fans de una ficción determinada, permite que crezcan sus intenciones de subsistir dentro del mundo virtual, sin la intención de competir con las empresas de televisión, sino de disponer de un universo paralelo en el que los fans se puedan expresar libremente, y en el que sus pares se sientan identificados y parte de esa comunidad.

\footnotetext{
${ }^{21}$ En https://www.facebook.com/Novelasycortosdezampivanez (Consultada: 7 agosto 2014).
} 
Este tipo de narración es estudiado en la presente investigación, porque aporta un elemento fundamental en la configuración de ciertas audiencias / usuarios que son a su vez prosumidores (consumidores que producen contenidos), al pretender manifestarse a partir de la creación de un universo paralelo, utilizando ciertos elementos característicos de una tira en cuestión, para poder crear su propia historia. Este escenario está mediado por acciones a nivel emocional, debido a que se involucran sentimientos, sentidos, en el momento de decidir introducirse en el universo de las narraciones transmediáticas.

Se expone un compromiso de parte de las audiencias/usuarios para con la tira. La ficción no es insignificante para ellos, sino todo lo contrario, provoca e intensifica su creatividad, dejando al descubierto su capital simbólico, lo que la tira representa para ellos, lo que los motiva a crear.

En este contexto, la convergencia permite que una red social como Facebook, al disponer de un escenario integral, posibilite la publicación y la consecuente difusión de diversas narraciones transmediáticas que circulan por Internet. Constituyendo una plataforma representativa y participativa en el panorama que se está configurando. 


\section{METODOLOGÍA DE \\ LA INVESTIGACIÓN \\ CAPITULO IV}


El presente capitulo describe la metodología utilizada para la realización de la investigación. La técnica seleccionada es la Observación Flotante, la cual fue adaptada para el estudio de las nuevas tecnologías, focalizándome en las redes sociales, Facebook.

El constante movimiento en el que están inmersos los medios digitales, provoca que el enfoque metodológico escogido sea factible para analizar las múltiples variables que afrontan esta clase de investigación.

El propósito de este segmento es reunir los aspectos principales que dan forma y hacen posible la realización del presente estudio, reflejando en estas líneas, de la manera más gráfica y sencilla la experiencia de la investigación. Con ello se pretende ofrecer al lector una narrativa a partir de la que se darán a conocer las decisiones tomadas durante la fase práctica desde su puesta en marcha.

La selección de diferentes núcleos temáticos, a partir de los objetivos que cimentaron la investigación, permitirá un ordenamiento de la exposición, buscando tramas de sentidos que se desprenderán del trabajo de campo. 


\section{REFLEXIONES METODOLOGICAS}

Con el propósito de poner en funcionamiento los objetivos que impulsan la presente investigación Los usos de las redes sociales en la configuración de las audiencias televisivas de tiras argentinas, estuve en búsqueda de una metodología que sea capaz de estudiar los procesos que surgen y se desarrollan en Internet, específicamente en las redes sociales.

La indagación de una metodología a través de la cual se pueda investigar los usos de Facebook considerándolo como un espacio que forma parte de las prácticas de la vida cotidiana. Un espacio nuevo que conlleva diversas interacciones, que pueden ser examinadas desde una metodología centrada en técnicas antropológicas, como lo es la observación flotante.

A principios de los años 80, desde el campo de la antropología urbana, la Etnóloga Colette Petonnet presenta un modo de observar la ciudad que sea compatible con el movimiento constante y la circulación incontrolable de los espacios públicos. Según la investigadora todo se mueve, todo cambia, todo lo que sucede va a desaparecer y otras nuevas formas de cultura surgirán y, a su vez, se volverán a desvanecer.

De esta manera, surgía la necesidad por lograr una renovación metodológica que posibilitara analizar los procesos dinámicos de la vida en las ciudades, siendo la observación flotante la técnica elegida.

Ea observación flotante consiste en estar bajo toda circunstancia vacante $\mathrm{y}$ disponible, no enfocar la atención en un objeto preciso, sino dejarla flotar para que no haya filtro, que no haya a priori, hasta que aparezcan algunos puntos de referencia y de 
convergencia en los que uno llegue a encontrar ciertas reglas subyacentes". (Petonnet, 1982; en Neve, 2006).

La aplicación de esta técnica al universo de las redes sociales responde a la necesidad de trabajar en un campo fragmentado y en constante movimiento como el de las nuevas tecnologías. Por lo tanto, se realiza una adaptación de esta técnica a medios digitales que conduce a la realización de un estudio que como afirma el investigador Eduardo Neve, nos lleva a aprender a leer el fenómeno, encontrando tramas de sentidos a través de las cuales se pueda ir enfocando la mirada. A pesar de que este tipo de observación tiene como objetivo la abertura de la mirada, esto no significa vagar sin una meta definida. La presente investigación está regida por objetivos que guían el estudio.

La búsqueda de la trama de sentido, que es este caso se representa en cómo el uso de las redes sociales contribuyen a la configuración de las audiencias televisivas de tiras argentinas, permite que podamos desdoblar e interpretar nuestra mirada, y de este modo comenzar a enfocarnos en ciertas subredes que se desprenden de los objetivos propuestos.

La obtención de puntos de referencias, convergencias, sentidos que surjan me permitirá lograr investigar sobre los usos que los usuarios/audiencias realizan asiduamente o eventualmente, logrando un resultado que permita no solamente describir, sino reflexionar sobre dichos usos.

La temática requiere de un acercamiento metodológico que me permita sumergirme en el campo de estudio para poder aprehender la esencia de los fenómenos que observo pero que a su vez me permite moverme, no establecerme en un punto fijo, practicar justamente la observación flotante.

El estudio de un fenómeno como las redes sociales conlleva la necesidad de abordar un producto caracterizado por el imprevisto, que varía suficientemente rápido en el intervalo de percepción. Una esfera del ser humano habitada por el mí, aquí, ahora, según las investigadoras Moles y Rohmer (1983). 
Por lo tanto, la observación flotante permite captar la polifonía del entorno, la multiplicidad de estímulos que aparecen inusitadamente ante el investigador, quien es el responsable de plasmarlas tal y como ocurren en la realidad. Se describe un espacio en movimiento, con cruzamientos, confrontaciones, acuerdos, aparentemente inconexos pero que disponen de una trama de sentidos.

Las redes sociales son lugares interesantes de exploración debido a que en los espacios digitales no se ve al otro más que cuando se exteriorizan a través de discursos digitalizados: textos escritos, imágenes, videos, sonidos. Por lo tanto, tenemos que prestar particular atención a lo invisible, a las palabras que no aparecen, pues una parte importante de la construcción de significado no es visible, requiriendo un esfuerzo interpretativo (Neve, 2006).

A sí mismo, la categoría flotante no se refiere a una observación periférica, debido a que el contexto en el que se desarrollan los diferentes usos digitales posibilitan este tipo de estudio, a pesar de la celeridad y simultaneidad de los acontecimientos que surgen en las redes sociales en referencia a una tira. Por consiguiente, este tipo de técnicas permite un modo de acercamiento, de proximidad con el objeto de estudio, a las dinámicas concernientes, a los intercambios dentro del universo digital.

Con la elección de dicha metodología, pretendo alejarme de entrevistas, encuestas; realizando de este modo, una reconstrucción de redes sociales creadas sobre una tira. Interpretando los usos a través del contexto, y a la vez, estudiando ese contexto por medio de los usos. Analizando las interacciones, las rupturas y continuidades que se desprenden de las tiras. A sí mismo, Eduardo Neve plantea una limitación al considerar a Internet como un medio para realizar solamente entrevistas o encuestas, siendo pertinente una adaptación de la observación flotante, para lograr una aproximación interpretativa en investigaciones sobre tecnologías digitales, sobre las cuales es necesario interpretar los sentidos en los contenidos publicados en las redes sociales, que están en un movimiento permanente. 
En consecuencia, la observación flotante implica una percepción alerta de mi labor como investigadora, que me permita captar la información necesaria con el propósito de reelaborar posteriormente un conocimiento. De este modo, combinaré el estudio empírico de la actividad de las audiencias/usuarios inmersos en Facebook y mediados por un contexto digital.

Además de las dinámicas de interacción, sus opiniones, debates por escrito, en este tipo de técnica, toman relevancia las imágenes, videos publicados, que presentan un contenido simbólico, que requiere un análisis pertinente debido a que puede ser de utilidad para seguir comprendiendo y reflexionando sobre los diferentes usos, en el contexto de las redes sociales.

Al decidir sobre esta metodología, procuro lograr una aproximación crítica, que se centraliza en las dinámicas de interacción, y que sea capaz de describir la rapidez y transformación de los procesos digitales, analizando los usos de la red social Facebook, los cuales generan diversos significados.

Por consiguiente, la apropiación que se realiza de los Facebooks sobre tiras argentinas será estudiada a partir de observar cómo transitan de manera flotante, haciendo suyo el espacio otorgado por la red social, entendiendo a esta clase de metodología como un proceso en donde predomina la observación, interpretación y reflexión constante. 


\section{ESTUDIO DE CASO}

En esta fase propongo poner en funcionamiento los diversos objetivos que guiaron la realización de esta investigación, confrontando, reafirmando e interpelando cada uno de ellos, de acuerdo a las diferentes fases del trabajo de campo por las que atravesé, considerando que un objeto de estudio vinculado con las tecnologías y los usos de las redes sociales, está en contantemente movimiento.

A partir de la técnica metodológica seleccionada, observación flotante, realicé entre el período febrero de 2013 - noviembre de 2014 un reconocimiento de diversas tiras argentinas del prime time que se emitieron durante ese lapso de tiempo, focalizando no solamente en las interacciones entre los usuarios a través del Facebook, sino también en las diferentes estrategias utilizadas por los canales de televisión para con las audiencias/usuarios.

Con el propósito de no permitirme condicionar por una sola ficción televisiva, y considerando que mi objeto de estudio era aplicable a las tiras en general, decidí explorar las diversas tiras que se transmitieron en ese período de tiempo, sin discriminar en el género que abordaban, debido a que el objetivo fundante de esta tesis era analizar la configuración de las audiencias televisivas a través del uso de las redes sociales, más allá del contenido o tratamiento de una temática en particular dentro de una tira.

Una aclaración necesaria es que el universo de análisis no focaliza en una franja etaria ni clase social en particular, debido a que considero que no es relevante ese tipo de distinción en una tesis con estas características, al entender a las redes sociales como un espacio en el que se cruzan edades, sexo y diversas nacionalidades. 
Desde de la fase inicial del trabajo de campo (febrero de 2013) se tomaron como referencia los Facebooks oficiales de las tiras en cuestión, sin embargo, es preciso aclarar que también se estudiaron diferentes páginas webs como foros, blogs, Facebook, que se desprendían de una tira determinada, y eran publicitados por parte de los usuarios que participaban en los Facebooks oficiales, invitando permanentemente a la participación.

Desde mi posición de investigadora me limité a observar y registrar, absteniéndome de intervenir en los Facebooks, debido a que me interesaba focalizar en la interacción independiente del observador. Sin embargo, el trabajo de campo siempre estuvo regido por la interpretación de las prácticas desde la perspectiva de las audiencias/usuarios.

La división del trabajo de campo se realizó a partir de una categorización de diferentes núcleos temáticos que se desprendieron de los objetivos de la investigación, permitiendo una organización del estudio, con el pertinente desarrollo y profundidad de cada categoría. La elección de cada categoría que responde a su vez a un objetivo específico fue escogida con el fin de lograr un orden y una organización dentro de la investigación.

La distribución del trabajo de campo a partir de núcleos temáticos, no significa una estructuración del estudio que impida ir más allá de los objetivos planteados, sino que por el contrario, se convirtieron en el disparador inicial para reconocer nuevos escenarios que surgieron durante la investigación.

Por lo tanto, las categorías definidas, con sus núcleos temáticos fundantes, son:

Facebook como un espacio de debate, expresión y configuración de grupos que se interpelan como audiencias / usuarios.

Sentidos que le otorgan las audiencias/usuarios a las tiras a través de sus participaciones en Facebook. 
Intervenciones de las audiencias/usuarios en Facebook intentando provocar cambios en el desarrollo de las tiras.

\author{
Identificación de audiencias/usuarios con situaciones, personajes que se \\ desarrollan en las tiras.
}

Estrategias de comunicación que utilizan los canales de televisión a través de Facebook para con sus audiencias/usuarios.

Una vez generadas dichas categorías me dediqué a realizar el trabajo de campo, a partir de un abordaje metodológico que incluye la observación flotante dentro de los Facebooks oficiales de las tiras del prime time de la televisión argentina; a partir de la cual se pueda analizar, definir y describir elementos constitutivos y de contexto acerca de los usos de las redes sociales en la configuración de las audiencias televisivas de tiras argentinas 
- FACEBOOK COMO UN ESPACIO DE DEBATE, EXPRESIÓN Y CONFIGURACIÓN DE GRUPOS QUE SE INTERPELAN COMO AUDIENCIAS / USUARIOS.

Con el paso del tiempo Facebook se convirtió en un espacio que permite el debate, la confrontación, el intercambio de opiniones entre las audiencias/usuarios de una tira en cuestión. Es una red social común a todos, a la que se puede ingresar cuando lo deseen, para tratar algún aspecto sobre la ficción que siguen.

Además, pueden publicar información sobre los actores, la incorporación de un nuevo artista, cambio de trama, especulaciones sobre un romance entre algunos integrantes del elenco, es decir diferentes noticias que funcionan como el disparador de nuevos debates.

$\begin{array}{ccccccc}\text { En } & \text { el } & \text { Facebook oficial } & \text { de } & \text { la } & \text { tira } & \text { Guapas } \\ \text { (https://www.facebook.com/guapas.eltrece?fref=ts) } & \text { se } & \text { originó } & \text { un } & \text { debate } & \text { sobre la } \\ \text { incorporación de la actriz Dalma Maradona a la ficción. Los comentarios demuestran un } \\ \text { malestar entre las audiencias/usuarios sobre la noticia que circulaba }\end{array}$


Valeria Aguirre Dalma Maradona no por favor!! Y ésteves tampoco me gusta tanto...q sea pasajero nada mas

Me gusta - Responder - 34 - 4 de octubre a la(s) 11:30

20

Ethel Beatriz Don Tursani no saquen a Lorena ,nos encanta esa historia no pongan actrices de cuarta,siempre lo mismo con los que hacen novelas ahora!cuando nos encanta una historia la cagan...no la vemos mas Me gusta - Responder - 3 - 5 de octubre a la(s) 6:30

Mariana Gómez Damiani Cómo van a cambiar a Bertotti por la tonta de Dalma Maradona!! Para eso hubieran terminado la novela... Igual no la va a mirar NADIE AHORA..

Me gusta - Responder - 3 - 4 de octubre a la(s) 15:01

Soraya Sanchez Pardo chau guapas aca termino la novela para mie prefiero este final

Me gusta - Responder - 3 - 4 de octubre a la(s) 11:34

Alicia Teresa Selak esa uma cagada la novela,.,., no la miro mas

Me gusta - Responder - 33 - 4 de octubre a la(s) 11:28

Marta Viviana Salazar NOOOODalma Maradona ,no tiene peso !!Hay tantas actrices en serio !!!

Me gusta - Responder - 3 - 7 - de octubre a la(s) 11:29

Mariana Marazzi Yo no la miro mas no peden sacar a lorena y poner a dalma maradona 0 a la esteves una cagada

Me gusta - Responder - 37 - 4 de octubre a la(s) 11:23

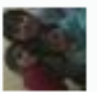

Maria Farias Ay no, yo quiero que se quede Lore porque? Quiero que este con el bombón del doc, che!! No es justo, ufa!!

Me gusta - Responder - 32 - 5 de octubre a la(s) 23:16

Liliana Graciela Fernandez La verdad cago todo Florencia Bertotti. No se acordo al firmar el contraro que tiene familia? Que no trabaje mas, y que sea ama de casa que va a trabajar las $24 \mathrm{hs}$ del dia. Lo dejo pagando a Mike. Me gusta - Responder - 32 - 5 de octubre a la(s) 15:50

Antonella Escobar Dalma Maradona no me gusta como actriz, las dos incorporaciones me parecen un asco. Que vuelva Lore, Laura esta insoportable...

Me gusta - Responder - 32 - 5 de octubre a la(s) 14:58

\section{Imagen del Facebook oficial de Guapas (Octubre 2014)}


La misma disconformidad se produjo en la tira Farsantes, en el momento en el que incorporaron al actor Guillermo Pfening, como una posible pareja romántica del personaje interpretado por el actor Julio Chávez.

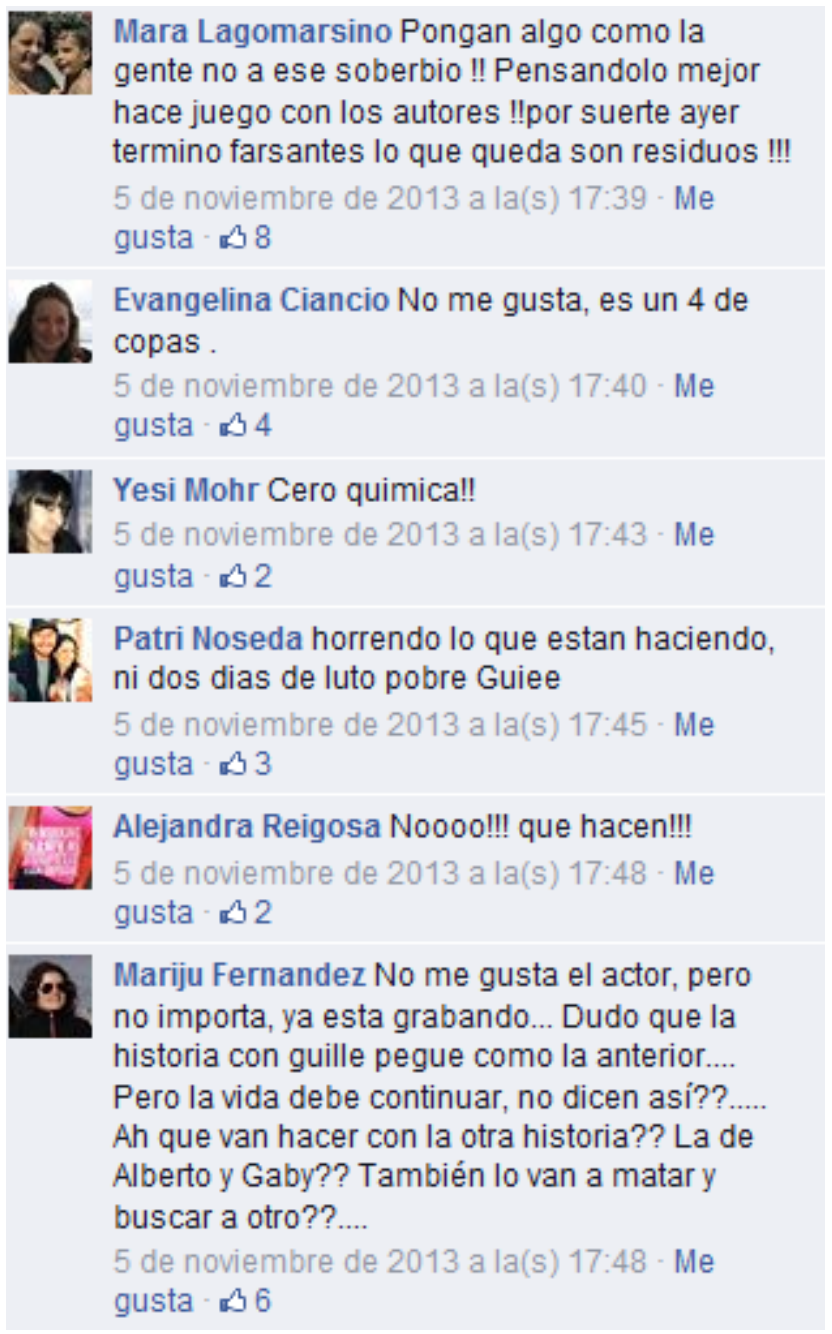

Imagen del Facebook oficial de Farsantes (Noviembre 2013) 
Asimismo, utilizan Facebook para exponer desenlaces posibles de la trama de algunos personajes de la tira, sus deseos y sugerencias no se hacen esperar al momento de imaginarse el final de la ficción.

La aparición de diferentes versiones de un final se suscita en un marco repleto de expectativas sobre la culminación de una historia, donde la ansiedad por saber qué va a ocurrir, es la protagonista en los tramos finales de la tira.

En la tira Dulce Amor, unos días antes del final, en el Facebook oficial (https://www.facebook.com/tlfdulceamor?fref=ts), las audiencias/usuarios comenzaron a debatir sobre cómo finalizaría la ficción, qué ocurriría con las parejas protagónicas, cuál sería el destino de los villanos, es decir, cómo proyectaban el desenlace de la tira. 
Maria Victoria Toyos El capitulo buenisimo, mi opinión es que tiene que terminar Vicky con Marcos con hijos, Brenda con Lucas, Julián con Natacha, Flor con Benja y Diego, Lorenzo y Angi presos o en el Ioquero, Bruno con Maite, Gisela se va, Pepe con Elena, Isabel con Zomoza, Máquina y Coni con hijos, el terco con la mamá de Lucas, Gabriela sola con Nano, Ciro se va de viaje con la mamá, Barrios preso, Emilio con su gran amor Cris. BUENISIMA LA NOVELA.

27 de abril de 2013 a la(s) 3.51 . Me gusta 05

Mayra Villamayor el mejor capitulu para mi se descubre q lorenzo mato a montalvan termina preso y todos felices esta buenisima la novela espero a den la segunda parte

27 de abril de 2013 a la(s) 9-29. Me gusta $\triangle 1$

Juliana Brent jBrenda con Ciro... ( Lucas solo la hizo comu....) Pero sabemos como se manejan los telenovelone... Nada distinto.

27 de abril de 2013 a la(s) $9: 59$ - Me gusta $\approx 2$

Cynthia Acosta sii lucas chau!! y Natasha tambien chau!l!

27 de abril de 2013 a la(s) 10:23 Me gusta $\$ 2$

Sofi Iglesias termina que Julian se queda con Gisela, Brenda con Ciro, Elena con Pepe, Lorenzo preso y Angeles libre porque escapa, Barrios quiere escapar pero lo detienen

27 de abril de 2013 a la(s) 10:55 : Me gusta : B2

Lore Rojas Termina como se conocieron. Marcos con Vicki obvio, Natasha con

Julian y Brenda con Lucas. Los demas presos o muertos jeje

27 de abril de 2013 a la(s) $11: 17$. Me gusta a 1

Lore Rojas Los malos obviamente

27 de abril de 2013 a la(s) $11: 17$. Me gusta a 1

Jonathan Jesus Juarez Lorenzo Matará A Marcos In!m, ..... Y Todos Llorando Y

Lorenzo Ira Preso Pero Llorará Por Lo Que Hizo..

27 de abril de 2013 a la(s) 11:43 - Me gusta

Juuli Sanchez jajajaja jonathan si termina asi es la novela mas ridicula

27 de abril de 2013 a la(s) 1322 - Me gusta

Rosa Taborda no Lorenzo preso agarrado con las manos en la masay

Vky.Maros casados y felices, nose si no terminan con hijos!li!

27 de abril de 2013 a la(s) $13: 33$ - Me gusta

Imagen del Facebook oficial de Dulce Amor (Abril 2013)

Como expuse en el capitulo anterior, era tal el grado de fanatismo y repercusión que provocó esta tira entre las audiencias/usuarios, que ellos mismos crearon sus propios blogs, en los que publicaban diversos capítulos de la historia. Sin embargo, el vínculo con el Facebook Oficial de la tira no se perdía, porque las audiencias/usuarios realizaban publicaciones, invitando a leer y participar de la continuación de la historia creada por ellos mismos. 
El fanatismo hacia cierto personaje o pareja de ficción también se hace presente en Facebook. El deseo por saber cómo sigue la trama, si van a volver a estar juntos, los cuestionamientos sobre por qué la pareja continúa separada, las expectativas por el próximo beso, se convierten en interrogantes que se plantean en el momento de debate, vislumbrando el fanatismo que produce una pareja, despertando diferentes emociones.

Ser fan es recursivo y autorreferente, concentrándose en un mismo objeto, y el placer que obtiene proviene del vínculo que establece con ese objeto más que del objeto en sí (Grossberg. 1992). De este modo, el fanatismo puede ser producido por una identificación con un personaje o una situación, o también puede ser una idealización y resignificación de una historia que se desearía vivir y no se consigue.

Siguiendo esta lógica, Henry Jenkins (1992) aborda la concepción del fanatismo como el ejercicio de prácticas críticas e interpretativas que lo alejan de la información estrictamente recibida en el texto primario, originado por la industria, propiciando de este modo, la construcción de un metatexto, en donde los fans se sienten consumidores con derecho sobre los productos que los convocan y, en consecuencia, emprenden acciones diversas de reclamos hacia la industria; nucleándose en comunidades sociales alternativas, consideradas como un espacio de sociabilidad alternativo.

Determinadas parejas de ficción producen diferentes grados de expectativas, ensoñación, ilusiones de querer cambiar la realidad que uno está viviendo, deseando poder conseguir algo o alguien que se tuvo y se perdió o que uno proyecta tener en un futuro. Dentro del fanatismo todo está mezclado, los sueños, anhelos, emociones; existiendo una combinación de sentimientos en el momento de ver una situación representada en una ficción. 
En la ficción Guapas, una de las parejas protagónicas conformada por la actriz Carla Peterson (Mey) y el actor Alberto Ajaka (Donofrio) producen un fanatismo inusitado entre sus seguidoras, quienes debaten sobre diferentes situaciones por las que atraviesan los personajes en cuestión.

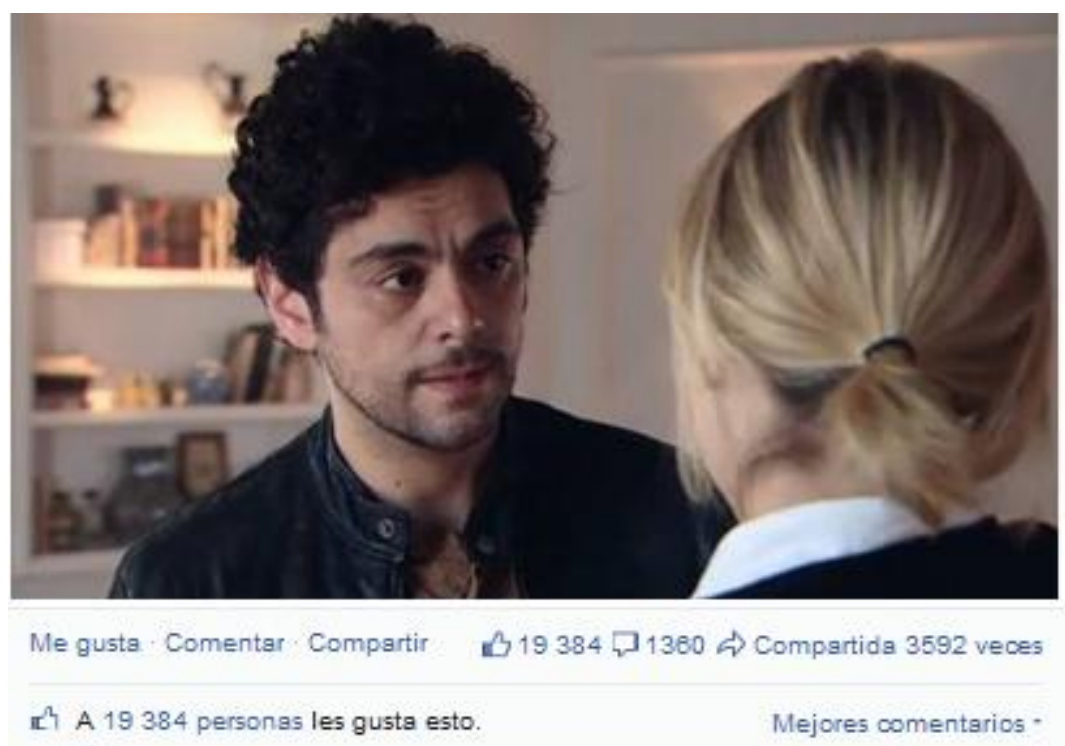

13. Escribe un comentario...

6 Brenda Diez Voy a llorar, donde esta el Donofrio de mi vida? jaja

Me gusta - Responder - $3245 \cdot 28$ de mayo a la(s) 22:55
I. Magda Bel Fuentes no sera algun amigo que mandaste a la friendzone hahahaha Me gusta $\backsim 10$ 26 de mayo a la(s) 22:58
Wi. Paola Yanicola que lástima que ella no lo ve....digo, al amor pasar por delante de sus ojos... Me gusta $\$ 4 \cdot 26$ de mayo a fa(s) $23: 00$
D. Ver más respuestas
28 Escribir ung respuesta..

Lorena Vanesa amor y sensibilidad pura!!! con un hombre asi, me iria al fin del mundo!!

Me gusta - Responder $\$ 289 \cdot 28$ de mayo a la(s) $22: 54$

Wato Padriguez SOMOS DOS

Me gusta - 31 - 26 de mayo a la(s) 22:56

9.2 Mag Gómez totalmente de acuerdooooo Me gusta 28 de mayo a la(s) $22: 57$

Imagen del Facebook oficial de Guapas (Mayo 2014) 


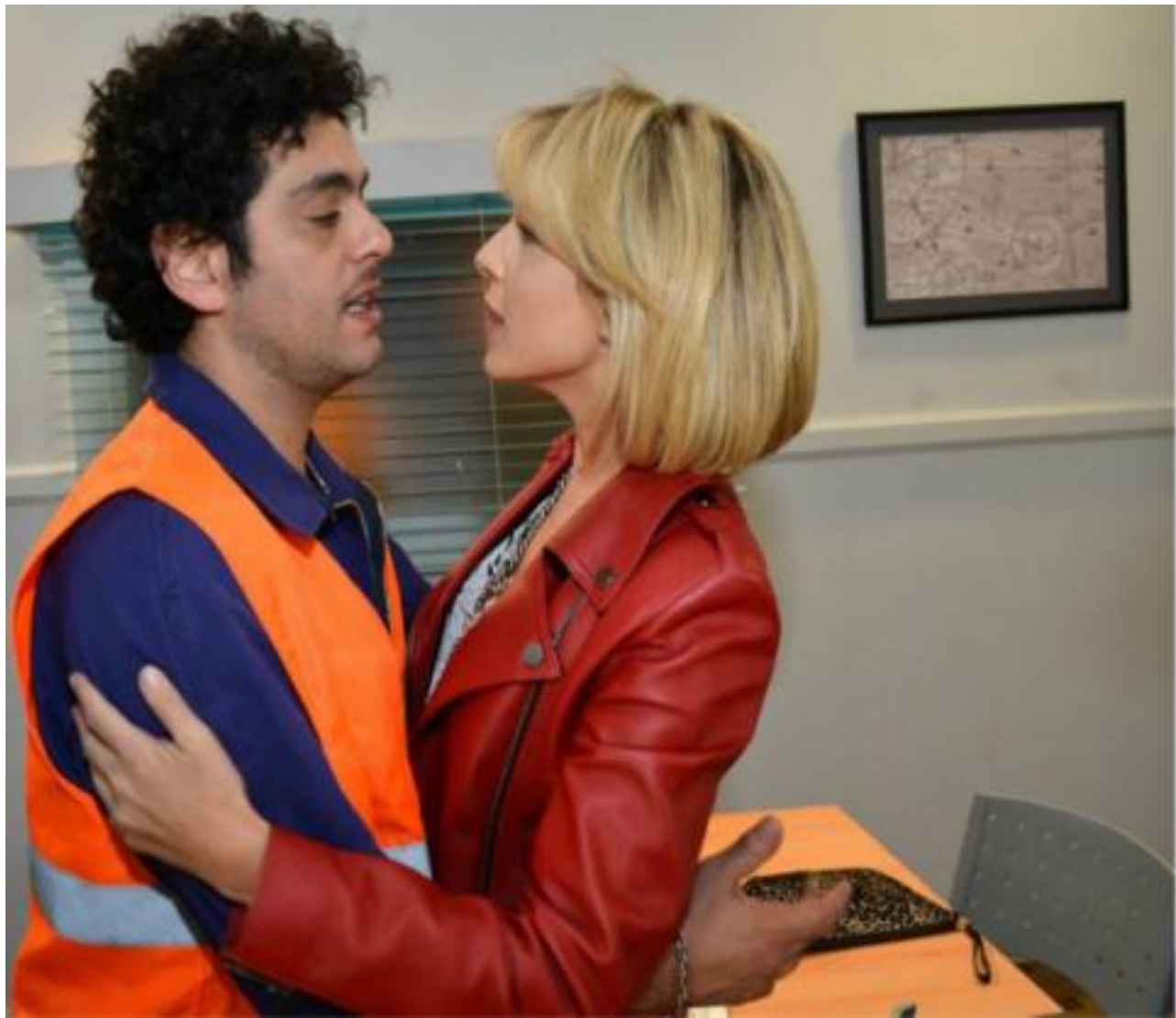

Gabriela Amor A la Libertad Me mata cuando a Mey se le sale el:"Ay Dono!" Mo gusta Responder 04 E deaponte a (1)as) 1900

D2

Maria Inés Rodriquez Decile que siiiii

boludgas, ni en la casa de $\mathrm{el}$, ni en la de ella, vendan todo y compren una nueva ain cosas del pasado que intoxican sus vidas y vivan felicessalt!

Me gusts Respondes: $03 \quad 5$ de soosta 8 $\ln : 56) 18: 07$

s.5. Guapas Rio Cuarto SONLO MAS

Me guats Responder $\Delta 2$ s de agoita (1)(x) 1728

1. Mabick Carrizo son hermosossss

1 Me gusta Responder $\Delta 25$ de aposis a (in:iti 1814

2. Josue Giacomo al fin están juntos .... Q duren mucho!

Me guste Responder of 5 de apotis of a) $17: 16$

4. Yamila Anahi Torres Qe lindo!

Me qusts Responder of 5 de agorid s (a) 12$) 16: 53$

Q Betina Senra Hermosa pareja

Me gusta - Respender al 5 de wookte 8 (a) a) $10: 28$

(i)

Liliana Gonzaloz hermosos los dos

Me qusta Responder : $D 1$ soleapoeg 8 (a) 19$) 1647$

Evaribe un comentario

Imagen del Facebook oficial de Guapas (Agosto 2014) 
Zakumoto Mitaromirikiari Ya con que Donofrí haya ido a la casa de Mey significa que van a volver

Me gusta - Responder - 34 - 9 de octubre a la(s) 23:06

Ba] Barby Galeano ojala

Me gusta - $\backsim 1$ - 10 de octubre a la(s) 17:34

12. Escribir una respuesta.

Claudia Alejandra Martinez tienen que volverll hermoso los dos!

Me gusta - Responder - 34 - 9 de octubre a la(s) 23:03

Liliana De Godoy Ya se está poniendo denso Donofrio.... En realidad todo se está estirando demasiado...

Me gusta - Responder - 38 - 9 de octubre a la(s) 23:33

Gisela Contar Lo quieren mostrar a Laprida como bueno para que nos guste la idea que vuelva con Mey y a Donofrio con otra pareja,ya me estoy convenciendo que los escritores no quieren que estos personajes terminen juntos.

Me gusta - Responder - 33 - 10 de octubre a la(s) $22: 13$

Patricia Alejandra Patiño Horrible Donofrio para Mel

Me gusta - Responder - 34 - 10 de octubre a la(s) 7:50

Monica Zingaro todo mal...la.hist q mas me gusta y ya te dan ganas q vuelva con el otro mtras dono la humilla

Me gusta - Responder - 33 - 10 de octubre a la(s) 0:24

Susy Alvarez Dono, quedate con Mey.

Me gusta - Responder - 33 - 9 de octubre a la(s) 23:27

Marta Alicia Marchese a mi me sigue gustando Donofrio..- está bueno쓸

Me gusta - Responder - $b 3$ - 9 de octubre a la(s) 23:20

Marta Sampaoli Tienen que quedar juntos를

Me gusta - Responder - 33 - 9 de octubre a la(s) 23:16

Eii Yviish Loos Amoo (:)

Me gusta - Responder - 33 - 9 de octubre a la(s) 23:00

Alejandra Campos Pero siiiiii dejalo ir Mei,ya ba a caer solito,uno nuevo para Mei,ni Dono ni Fran:

Me gusta - Responder - $\_7$ - 10 de octubre a la(s) 0:39 - Editado

Imagen del Facebook oficial de Guapas (Octubre 2014) 
En la tira Dulce Amor, una de las parejas protagónicas conformadas por Carina Zampini (Victoria Bandi) y Sebastián Estevanez (Marcos Guerrero) también despertaron el fanatismo entre sus seguidores, quienes se expresaban a través del Facebook Oficial de la tira.

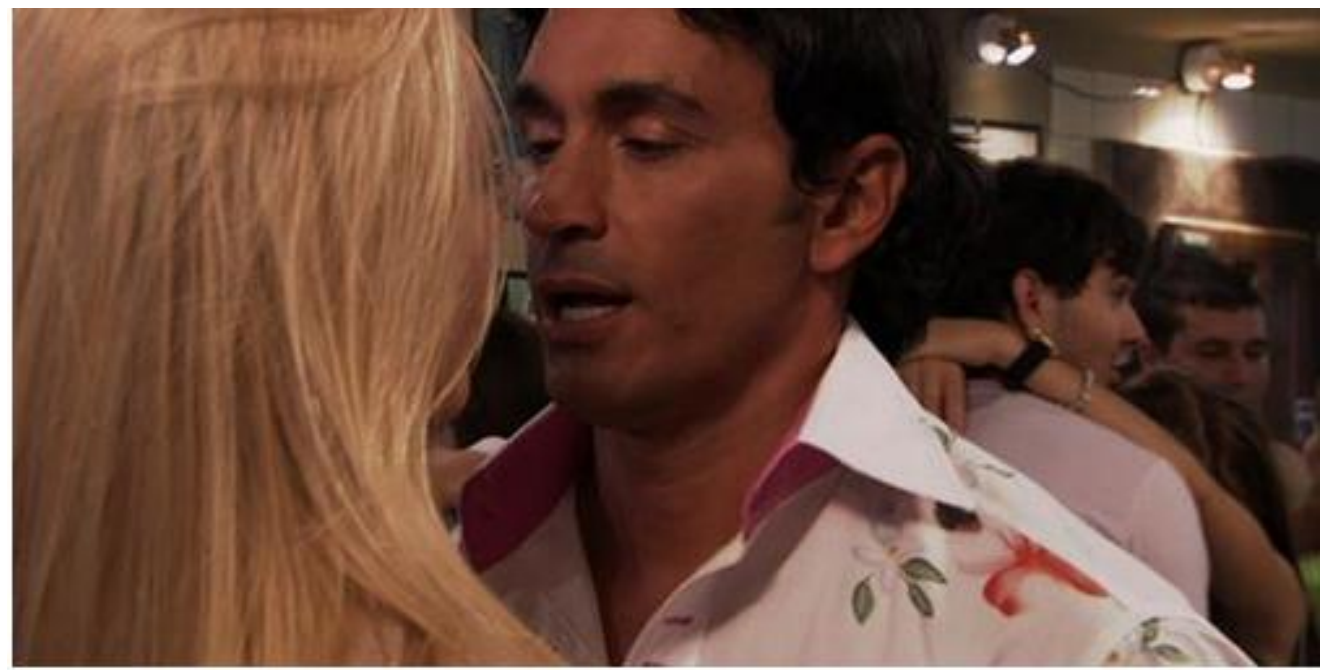

Me gusta - Comentar - Compartir $\quad \square 1344$ ه91 $\Rightarrow$ Compartida 63 veces

约 A 1344 personas les gusta esto.

Ver comentarios anteriores

\section{Liliana Mansilla era hora del baile}

23 de abril de 2013 a la(s) 14:39 - Me gusta

Lilian Graciela Perez hermoso capitulo !!!!!!!!!!!!!!!

23 de abril de 2013 a la(s) 14:41 - Me gusta

Wandiz Zapata aaaaaaaaaaaaaaaaaaaaaaaaaaaa dios que capituloo

23 de abril de 2013 a la(s) 14:58 - Me gusta

Almiron Sofia no quiero que termine (:)

23 de abril de 2013 a la(s) 14:58 - Me gusta

Ivii Gandulla re bonita la novela y la mejor historia del mundo y tambien son execelentes actores que lastima que se acerca el final se los va a extrañar siempre muchas gracias por alegrarnos todas las noches se los quiere un monton saludos y suerte para el final (:)

23 de abril de 2013 a la(s) 16:01- Me gusta - 31

\section{Imagen del Facebook oficial de Dulce Amor (Abril 2013)}




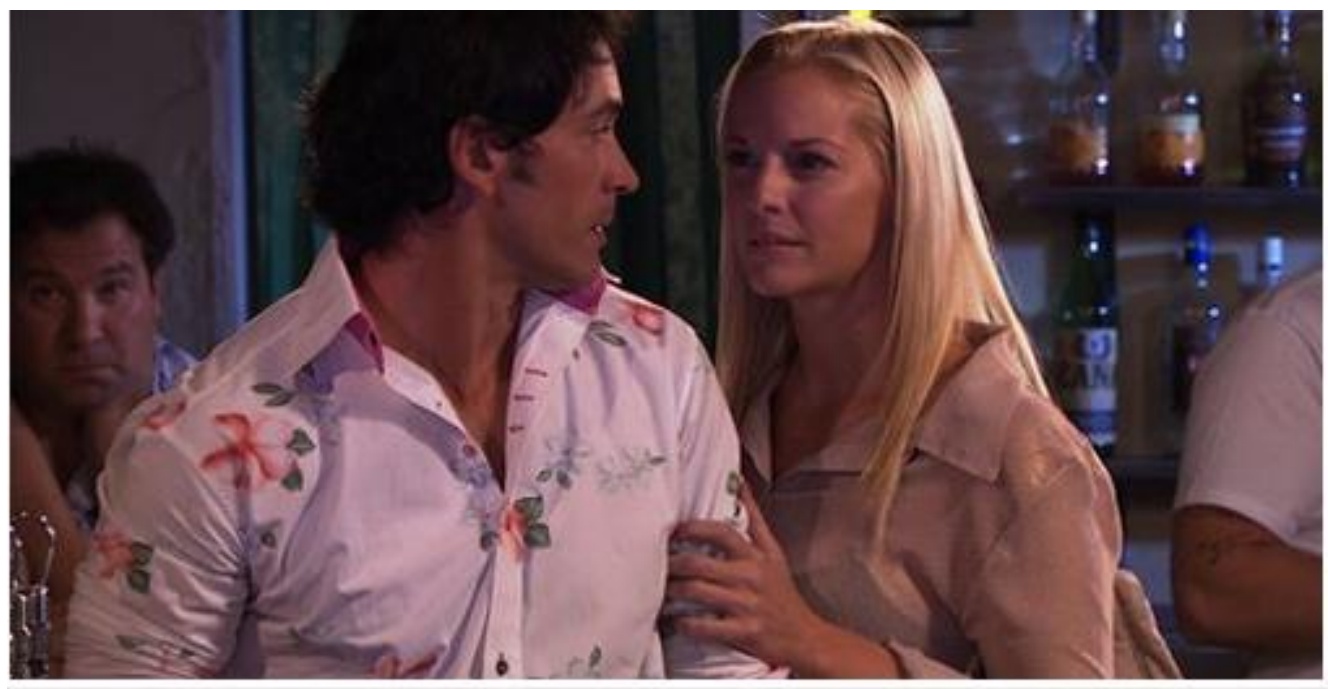

Me gusta - Comentar - Compartir

四 $1881 \square 89 \Leftrightarrow$ Compartida 94 veces

[C $A 1881$ personas les gusta esto.

Jen Vz cant wait

15 de abril de 2013 a la(s) 10:53 - Me gusta

Karenciita Antonella aguante marcoriaaa

15 de abril de 2013 a la(s) 10:54 - Me gusta - 31

Candee Yazmin QUE PASO, QUE PASO ? que no lo vi

15 de abril de 2013 a la(s) 10:54. Me gusta - 31

Cariitoo Ojedaa mash tiierno...!! qq no termineee...(:)

15 de abril de 2013 a la(s) 10:55 - Me gusta

Priscila Ayala no me lo pierdo ni empedo

15 de abril de 2013 a la(s) 10:57 - Me gusta

Vale Castro que ganas de verlos hoy !!!!

15 de abril de 2013 a la(s) 10:57 - Me gusta

Analia Panciarella necesito ver amor, mucho amor, necesitaria tb un abrazo de

Marcos, en este momento dificl

Imagen del Facebook oficial de Dulce Amor (Abril 2013) 


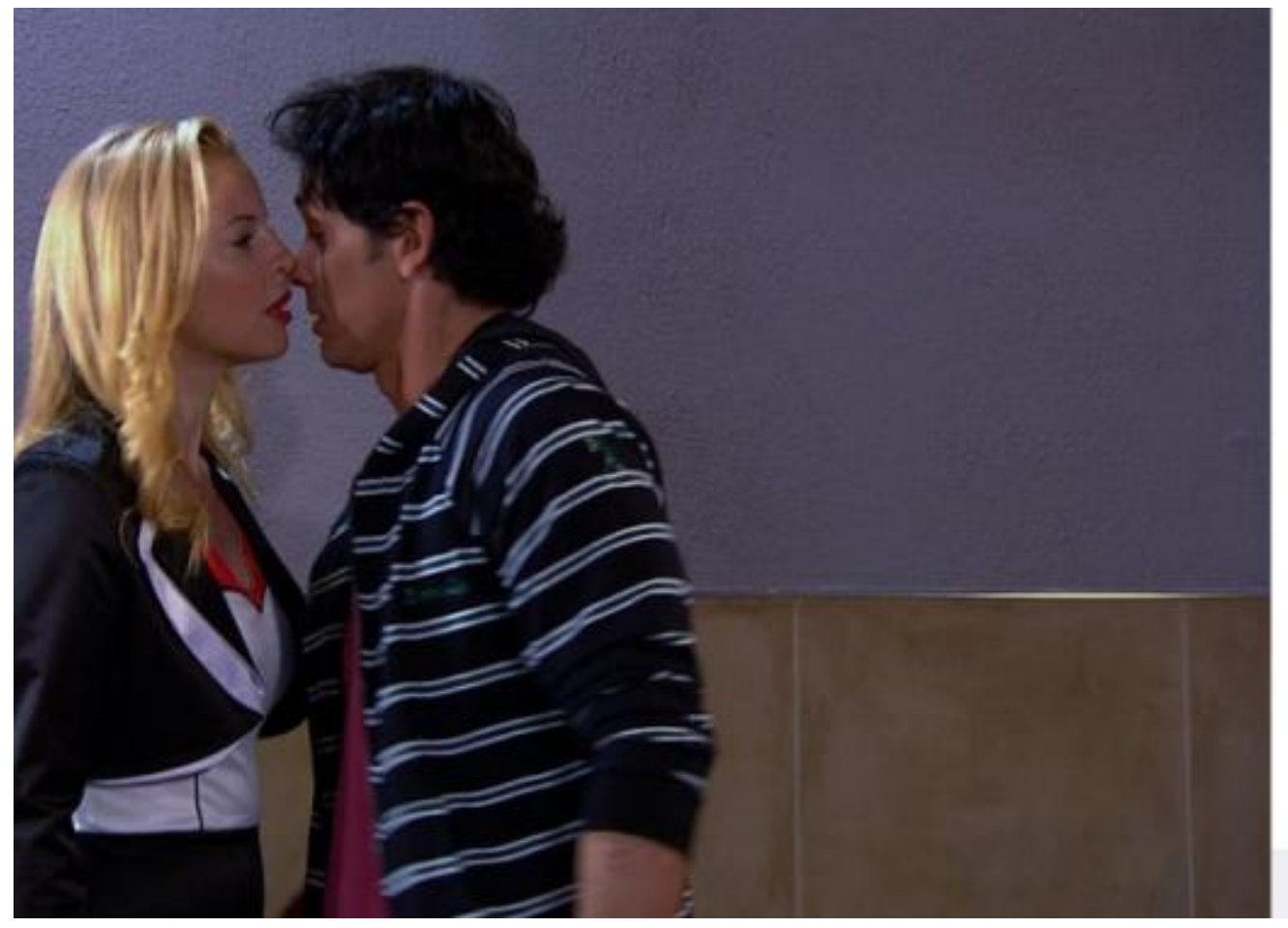

Esos besos marcorianos.

http:l/dulceamor telefe com/2013/05/10/besosmarcorianos/

Me gusta Comentar Compartir

c.) A 1990 personas les gusta esto.

0 Compartida 65 veces

6. Braian Valdez Ai amor! diria Leo!l XD

6 de mayo a la(5) 10.45 . Me gusta

Diego Perez 0000000 son hermosisimos los 2!II pero victoria es una diva total 5 de mayo a lafs) 10.45 Me gusta $\$ 3$

30. Lau Vilche SI QUE VUELVANNN 6 de miayo a la (5) 1047 Me gusta s 51

Wen Badilla Hasta el fin del mundo $\bigcirc$ 6 de mayo a la(s) 1047 Me gusta $\Delta 1$

Mari La Morocha los espero con ansias. son los mejores

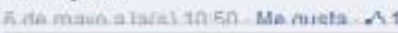
Escribe un comentario.

\section{Imagen del Facebook oficial de Dulce Amor (Mayo 2013)}

Las expectativas que produce una pareja de ficción no siempre se logra. El pedido constante de escenas juntos, el reencuentro, el primer beso, son situaciones que las audiencias/usuarios saben que van a ocurrir en cualquier momento, pero el deseo, las ansias de que se produzcan ya, son mayores y están presente dentro del fanatismo que provoca una determinada historia de amor. 
En el Facebook oficial de la ficción Farsantes (https://www.facebook.com/farsantes.eltrece?fref=ts ), se generó un debate acerca de un nuevo personaje que se mostraba enamorado del personaje principal interpretado por Julio Chávez (Guillermo Graziani). Las audiencias/usuarios intervenían molestas con el desarrollo de la trama, opinando sobre si era una posible pareja para el protagonista, y acusando que habian arruinado la trama.

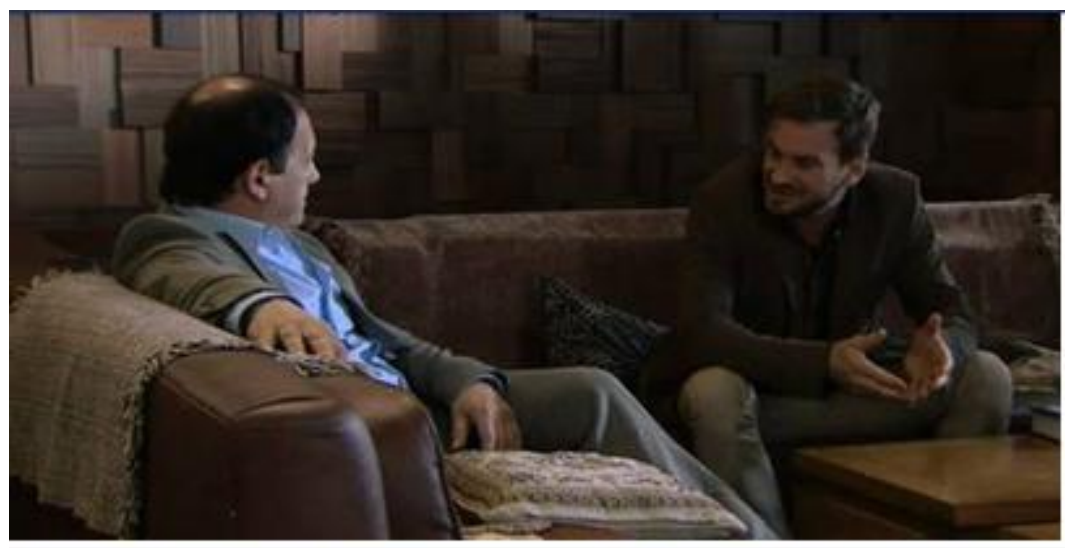

Me gusta - Comentar-Compartir

B217 $998 \Leftrightarrow$ Compartida 3 veces

I't A 217 personas les gusta esto.

12. Ver comentarios anteriores

Sabrina Perezlindo Yo no creo que Guillermo se enamore

nuevamente...amar como amó a Pedro nunca más...!!!!

28 de noviembre de $2013 \mathrm{a}$ la(s) 13:38 - Me gusta . B8

Lia Lareina Sabrina tenes razón!! Como Pedro nadie!!!

28 de noviembre de 2013 a la(s) 14:35 - Me gusta : 34

Gretel Witting Los guionistas. nos cagaron la historia sin pedro.

28 de noviembre de 2013 a la(s) 14:40 - Me gusta - 65

Marcela Korsak enamorado no oreo .. una relación al pasar tal vez, pero si no está Pedro ya no es amor, igual le tenía mas fe al fiscal q este pibe .. es un pesadooooo000

28 de noviembre de 2013 a la(s) 14:50 - Me gusta . B2

Maria Lopez Montiel pesado como collar de sandías !!! y no es lindo, este es un amorio del momento...

28 de noviembre de 2013 a la(s) 15:35. Me gusta - 01

Lucila González Un "me gustas" vs un: "lo me gusta es trabajar con vos, con vos las palabras se me salen,soñe con vos, no puedo parar de pensar en vos, lo unico para mi sos vos, no puedo imaginarme no verte mas, te extraño, te quiero, me gusto depertarme al lado tuyo, que vamos a hacer con lo nuestro? escapemos juntos, te espero calmo, completo, siempre" LAS TENGO GRABADAS EN EL ALMA Y EN EL CORAZON ESTAS FRASES...INBORRABLES!!! PEDRO T EXTRANNO!

28 de noviembre de 2013 a la\{s\} 16:01 - Me gusta 05

Imagen del Facebook oficial de Farsantes (Noviembre 2013) 


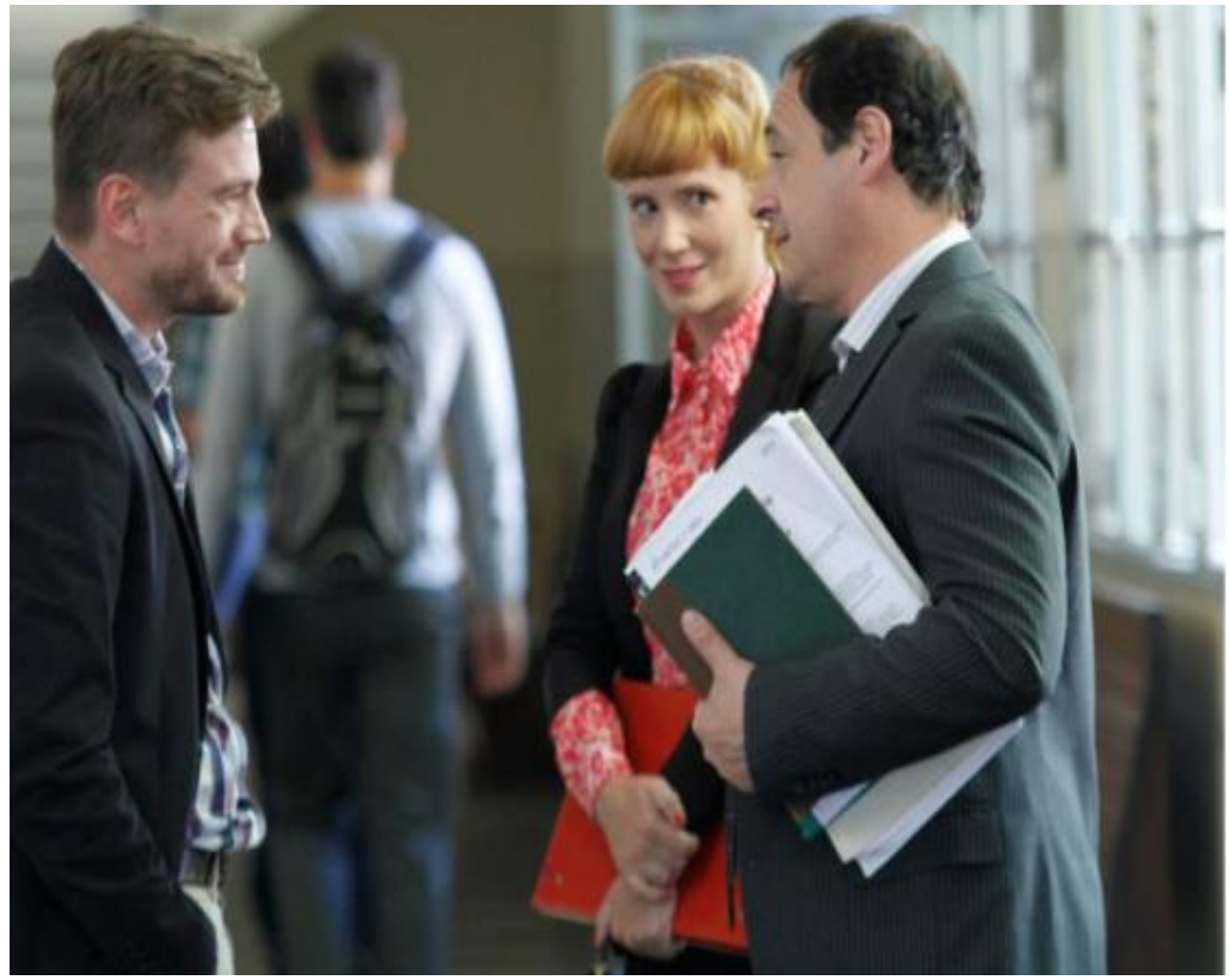

Flavia Giuliani Asco me da, no la pienso seguir viendo, todo lo que sacificó Pedro por Guillell. su vida, su matrimonio; se replanteb su sexualidad, su manera de vivit. fue incriminado on una cama que ora para Guillermo, quedó prófugo, se escapó de intentos de asesinato por parte del hermano de la persona a amaba, soportó el exilio, y murió con su nombre en sus labios. Pedro no se merecia un final asi, el amó con locurs a este hombre y se la jugó, pero perdib la vida...no me gusta, había muchos caminos alternativos para seguir y eligieron al peor. Hasta el cap 57 la novala es mágica, luego de eso los personajes se empezaron a desdibujar, a perder su esends, la trama se deformó, perdió fuerza. y la argumentación consistencia. Siento que luego del 57 me están contando otra historia, donde la trams es floja, las personalidades fluctúan todo el tiempo, saliéndose del rango donde siempre oscilaron, dónde la historia parece corregida a las apuradas y emparchadas por todos lados. Siento que se perdió la magia. la historia hace agus se terminó farsantes para $\mathrm{mi}$.

5 de noviemore de 2013 a la:3l 17,39 . Me gusts 017

B. Mimi Pèrez Ocampo NO DAAAAl!! gusts 03

6. Karina Corigliano coindido completamentellinimini!!

5 de noviembre de 2013 a las 3 i 1800 - Me

Imagen del Facebook oficial de Farsantes (Noviembre 2013) 
Andrea Méndez Quien se puede enarmorar de esa cosa pegajosa sin amor propio? Guille no.

2 de diciembre de 2013 a la(s) 15:33 - Me gusta $\$ 3$

Lucia Flores A mi me encanta. Ninguna cosa pegajosa.El tipo insiste pero de manera inteligente. Lo ban $\infty$ a Franco.

2 de diciembre de 2013 a la(s) 16:12 . Me gusta

7 Monica Hernandez A mi me dá dolor de cabeza y no transmite nada de nada...que no hay química por más que se empeñen...lo siento.

2 de diciembre de 2013 a la(s) 17:49 . Me gusta . 33

ce) Ela Kelly Si el es inteligente yo soy Albert Einstein ?

2 de diciembre de 2013 a la(s) 17:50 - Me gusta . 03

Q7. Andrea Méndez Por favor, el amor se construye, como lo hicieron

Guillermo y Pedro... esto es tan burdo.... un tipo que le hace marca personal todo el día, totalmente regalado....

2 de diciembre de 2013 a la(s) 17:50 - Me gusta : 02

6 . Monica Hernandez jajajajjajjaajajjas...no sé lo que le ve la gente , la verdad....lo siento el MAGIA solo aparece una vez y fué con Pedro...Pedro y Guille siempre juntos..

2 de diciembre de 2013 a la(s) 17:52 - Me gusta . 02

Ela Kelly Esto es amor...

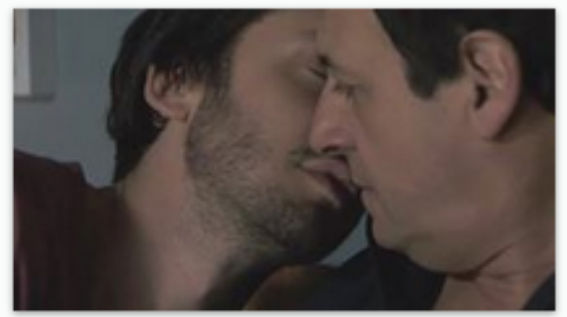

2 de diciembre de 2013 a la(s) 17:53 - Me gusta.$\$ 6$

Monica Hernandez Es verdad Ella , esto es amor...Lo demás es un locura . un mal aire...ya se me acabaron los nombres a que le dió a los guionistas y demás pandilla...

2 de diciembre de 2013 a la(s) 17:56 - Me gusta $\cdot 02$

4. Marta Carolei este era el gran amor

3 de diciembre de 2013 a la(s) 12:37 - Me gusta : 11

20. Cristina Garbini Este tipo, que asqueroso. No me lo banco, cuando aparece hago zapping .

7 de diciembre de 2013 a la(s) 23:13 . Me gusta $\$ 1$

Imagen del Facebook oficial de Farsantes (Diciembre 2013) 
Las audiencias / usuarios mostraron su disconformidad con la incorporación de un nuevo personaje, exigiendo que vuelva el actor principal Benjamín Vicuña, para que retome la pareja con Julio Chávez. Las diferentes opiniones sobre qué es el amor circulaban por el Facebook, recordando frases de amor entre la pareja protagónica, momentos que vivieron juntos, y lamentándose por la incorporación de un nuevo personaje que intentaría seducir y enamorar a Guillermo Graziani.

Un elemento que surge de los debates entre las audiencias/usuarios es como a partir de un giro de la trama, se comienza a debatir más allá de la ficción, qué es el amor, qué no es el amor, cómo se construye el amor. Diferentes tópicos surgen sobre una característica fundamental que presentan las ficciones televisivas, el amor. Si una pareja despierta pasión, lo que provoca cada pareja de ficción, si tiene o no tiene química, son los cuestionamientos que se hacen las audiencias/usuarios.

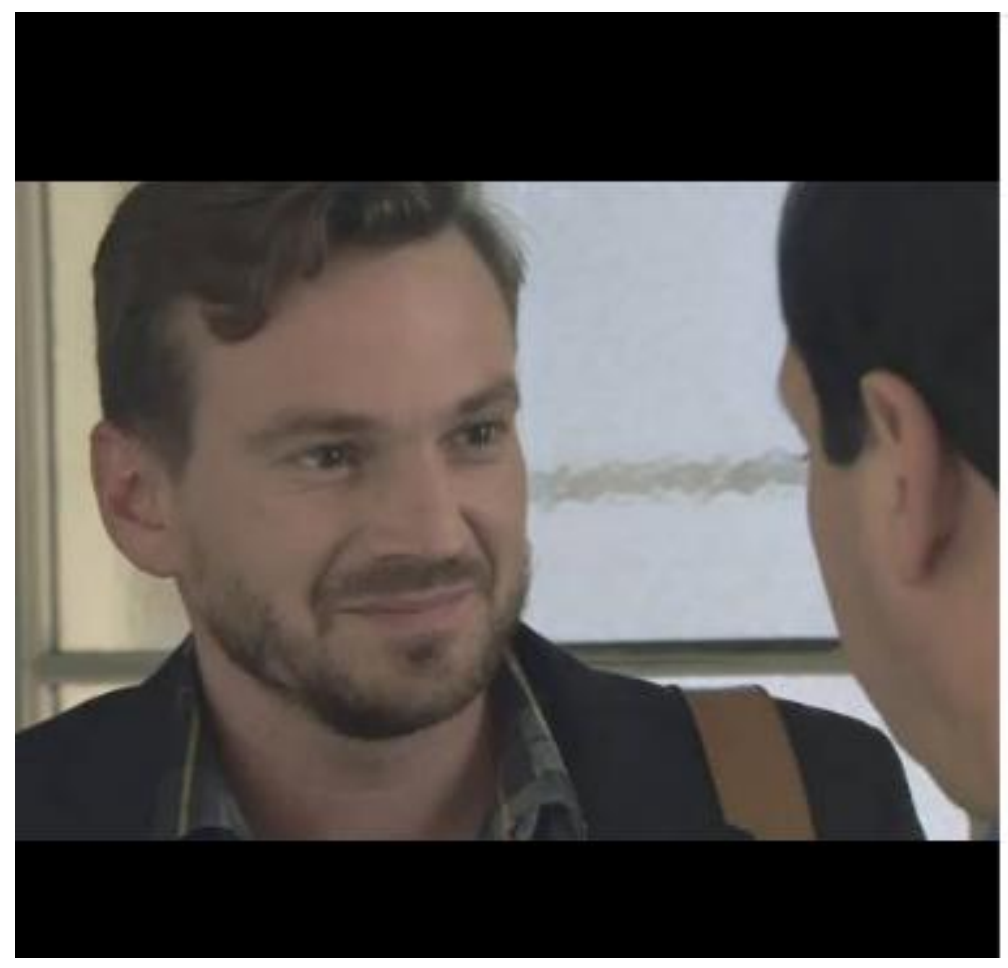

Betty Llanos franco va con todo. No es tan histérico como Pedro. Vamos todavía Guille.

13 de diciembre de $2013 \mathrm{~s}$ la(s) 17:46 : Me gusts : 91

Patricia Claudia Frances Franco es un acosador, parece un pendejo en su primer cita! muy regalado, Jose tiene otra onda, sabe lo que quiere $y$ espera 13 de diciembre de 2013 a la(s) 18:22. Me gusta: 31

Lucia Flores A mi me gusta Franco,lo que no me gusta es como generaron uns expectativa con esta relación, cusndo el fue hasta el depto, la invitaciñon de Franco en la oficina, un juego atractivo.Para que ahora lo presenten como algo sin importancia para Guillermo. No se si van probando las reacciones del público(no es bueno) o como lo plantean-

13 de diciembre de 2013 s la(s) 20:28 - Me gusta 02

Carmen lcardi van probando que personaje engancha mas al publico y evidentemente fue jose..

13 de diciembre de 2013 a la(s) 20:55 . Me gusta

Imagen del Facebook oficial de Farsantes (Diciembre 2013) 
A su vez, reflexionan sobre su condición de audiencia afirmando que los cambios de la trama deben pretender seducirlos con una historia nueva, probando quizás, las diferentes reacciones que surgen, dando cuenta de este modo, de la productividad de quienes consumen las tiras.

La interpelación constante de las audiencias/usuarios sobre ciertos pasajes de la trama, permite que ellos puedan pensar sobre los distintos tipos de prácticas que se desprenden de una tira, analizando cómo ellos creen que actúa la producción de una ficción, posicionándose en un rol netamente activo.

Las redes sociales de las tiras televisivas, son espacios que permiten que los usuarios expresen su voluntad, expongan sus ideas, pongan en común las propias singularidades, a través de procesos de cooperación, de participación conjunta. Aunque la tecnología ofrece diversas plataformas tendientes a lograr una comunicación fluida entre los usuarios, son ellos mismos los creadores de ese espacio, a pesar de que haya sido construido por la producción de la tira o por un usuario fanático de la tira en cuestión. 


\section{- SENTIDOS QUE LE OTORGAN LAS AUDIENCIAS/USUARIOS A LAS TIRAS A TRAVÉS DE SUS PARTICIPACIONES EN FACEBOOK.}

En los Facebooks dedicados a una tira en cuestión, se visibilizan contantemente los sentidos que las audiencias/usuarios le otorgan a una determinada ficción. A través de sus participaciones se puede desentrañar los sentidos que se ponen en juego en las publicaciones, y de este modo, poder comprender el sentido de dicha interacción.

Durante el trabajo de campo me encontré con diferentes situaciones que aparecían en los Facebooks, y que posibilitaban entender los sentidos que se suscitan alrededor de una tira en cuestión.

Un ejemplo son los videos musicales realizados por las audiencias/usuarios sobre una pareja de ficción, con una canción elegida a consideración de ellos, de fondo, sobre una selección de escenas escogidas de acuerdo a su preferencia, son un medio para otorgar sentidos a lo que lo están mirando, configurando múltiples significados que despierta una historia o pareja de una ficción.

El reconocimiento, emotividad, recuerdos, sueños, emociones se mezclan detrás de la realización de un video, en el que se piensa en los detalles de edición y musicalización, los cuales no son seleccionados al azar, sino que se desprenden de lo que provoca una canción y una escena determinada. 
En el mes de mayo del año 2014 comenzó la tira Camino al Amor ${ }^{22}$, protagonizada por la misma pareja de Dulce Amor, Carina Zampini y Sebastián Estevanez, quienes habían liderado el prime time del año 2013, sabiendo que no es común que se repita una pareja protagónica de ficción en televisión, y menos un año después de haber finalizado una tira que los tenía como pareja central.

El retorno de la misma pareja, a pesar de una historia y personajes diferentes, provocó que resurgiera el fanatismo que supieron cosechar en la tira anterior. A tal punto que los fans de Dulce Amor crearon el término Marcoria (unión de los nombres de los personajes), como una forma para denominarlos. Por su parte, en esta tira se creó un nuevo término a través de las redes sociales, Rolena, siguiendo el mecanismo de la unión de los nombres.

La creación de diversos videos musicales sobre dicha pareja son una muestra de los sentidos que las audiencias/usuarios otorgan sobre la historia de amor de los protagonistas.

\footnotetext{
22 Tira argentina, producida por L.C. Acción Producciones (Enri que Estevanez). Comenzó a emitirse el lunes 26 de mayo de 2014 finalizando el lunes 22 de diciembre de 2014, en el prime time de Telefe. Protagonistas: Sebastián Estevanez, Mariano Martínez, Carina Zampini, Juán Darthés, María Eugenia Suárez, Betiana Blum, Silvia Kutika, Sol Estevanez, Sofía Reca y Rodolfo Bebán. Directores: Hugo Alejandro Moser y Mauro Scandolari. El argumento se centra en el funcionamiento de una empresa de fletes familiar llamada Colucci, cuyo dueño es el padre de tres hermanos, quienes se reencuentran después de que su padre sufra un infarto. Por esta situación, Rocco (Sebastián Estevanez) debe voler al país, quien recién casado, debe alejarse de México, y quedar al mando de la mudadora. Sin embargo, su vuelta despertará la pasión y el amor, cuando se reencuentre con su amor de la juventud, Malena (Carina Zampini).
} 

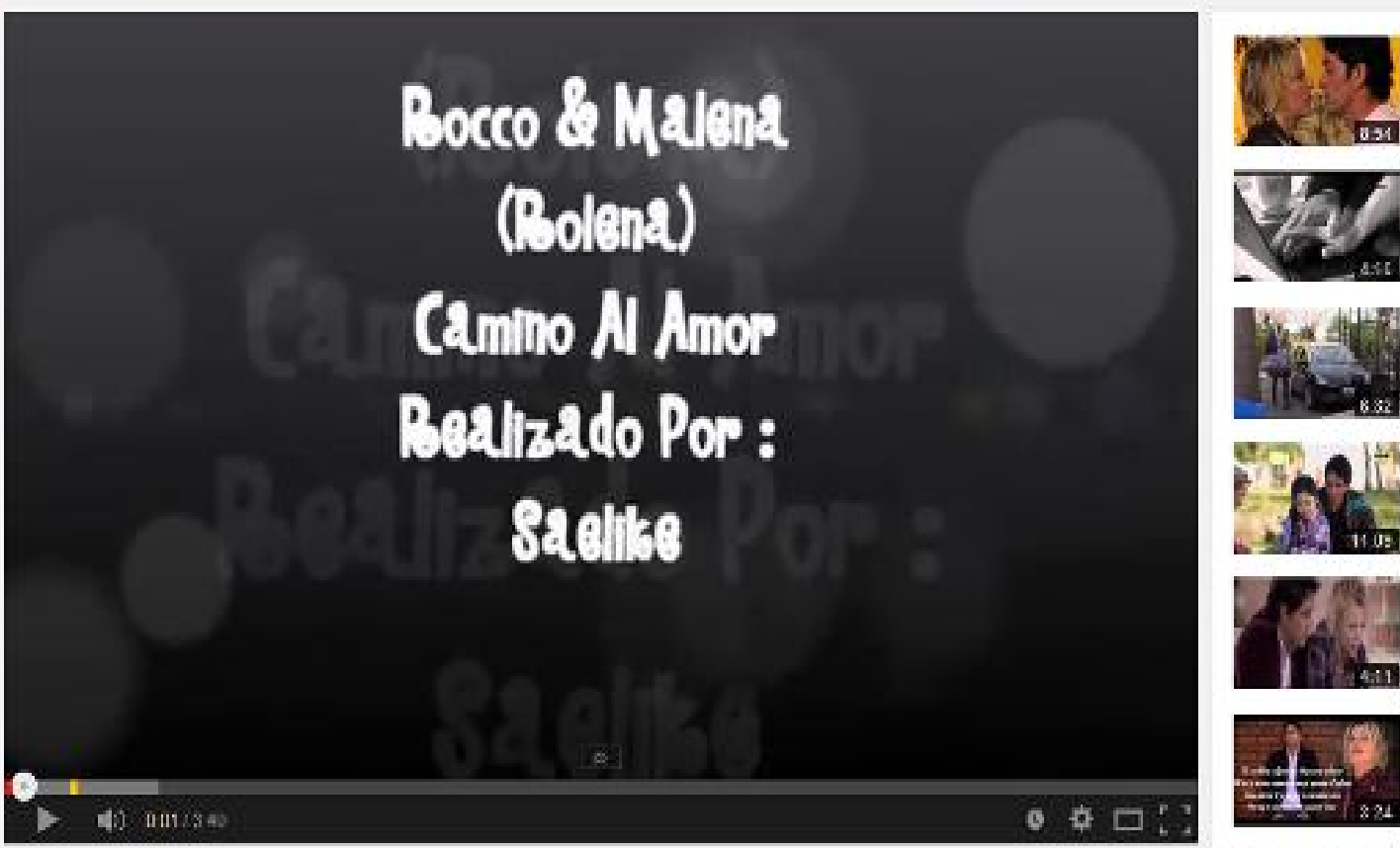

Tosas I os Tamas Re Camloo h Amor

in 1960-iviatsharto

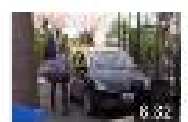

Aocen \& Malena Olublarte

iv anzes zal?

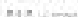

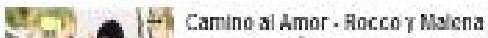

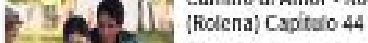

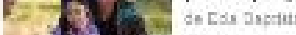

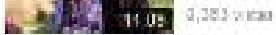

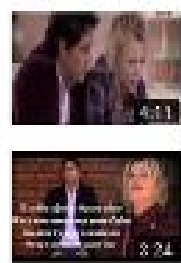

Aocce Y Malena tUn porso de tus abios nivases

\section{1,288 von}

Dacldlsta nด|arme - Camila (I FTRA)

Corthas Musical Do Camino A!

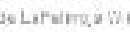

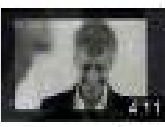

Sergovo Ualma- 'Un preso en tus atsoge

Rocco y Malena (Rolena) - Camino Al Amor - Vuelvo a Verte

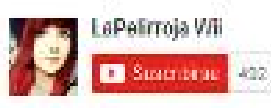

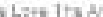

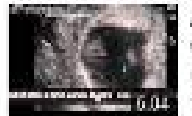

ACQUIESTOY..icancion para un bb

+ Agmar a $<$ comparir $\cdots$ mis 


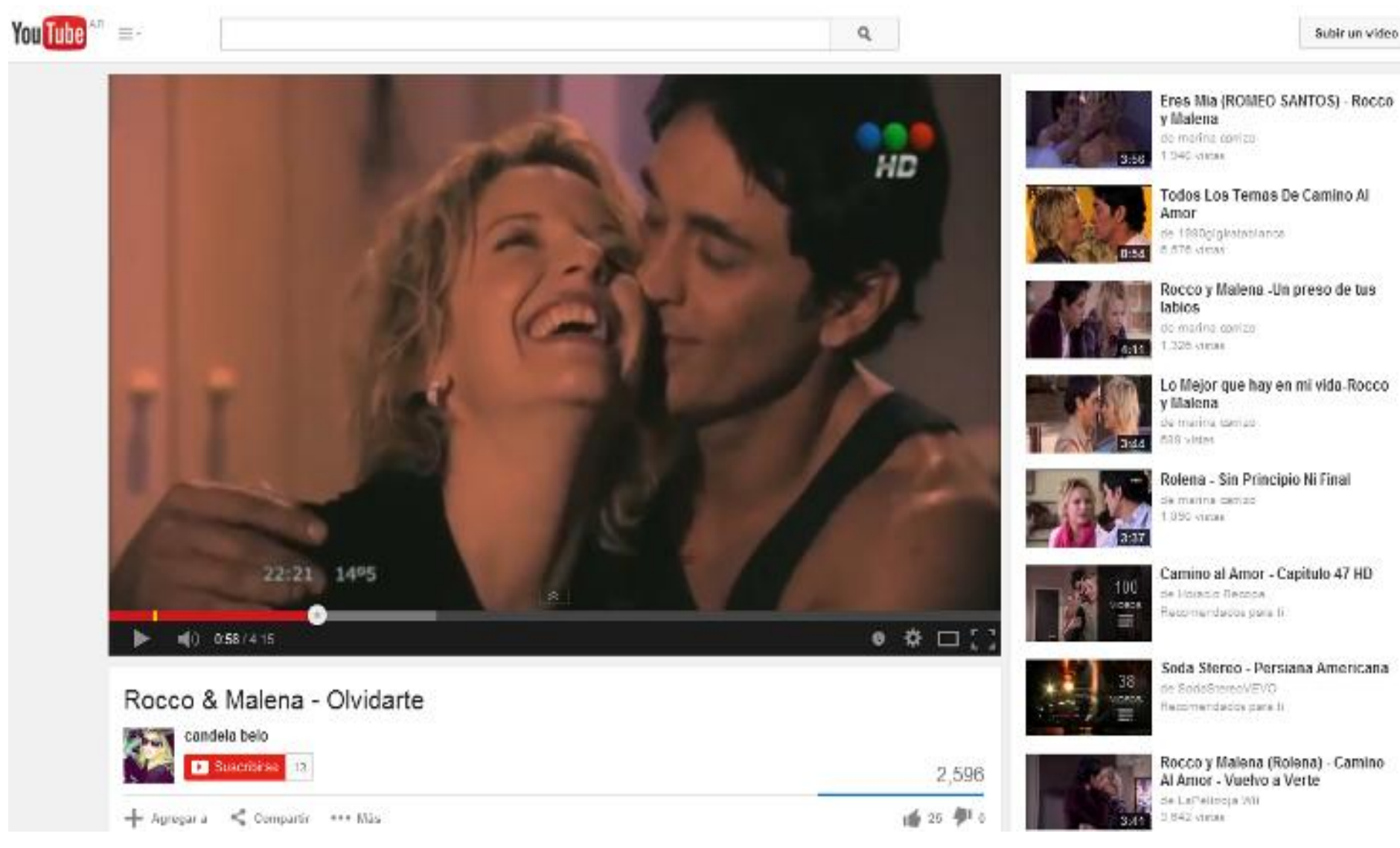

https://www.youtube.com/watch?v=r4TM1HJpARM

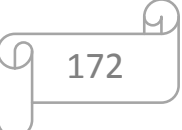



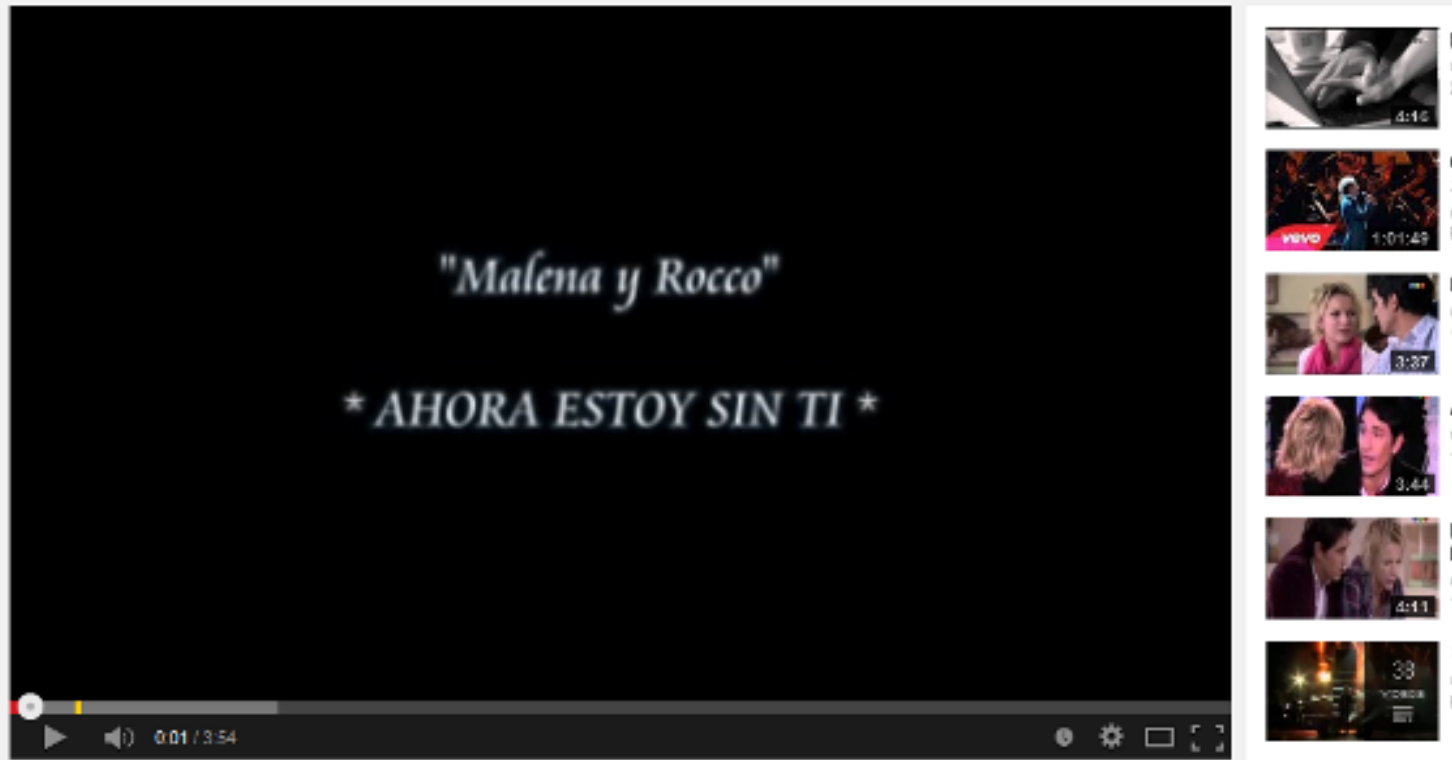

Rocco \& Malana - Olvidarte to cansala set:

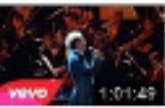
Gustavo Cerati - 11 Episodios Sinfónicos 2001 - Complato

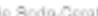

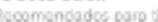

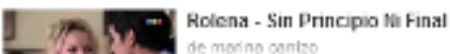

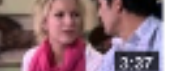
coso vatas

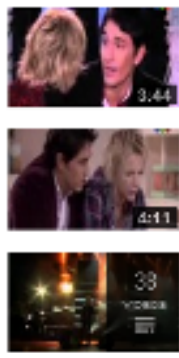

Acui Estory-Rocco y Malena ju meine comise 198

Malena y Rocco (\#Rolena) - Ahora estoy sin ti (By Lucero)
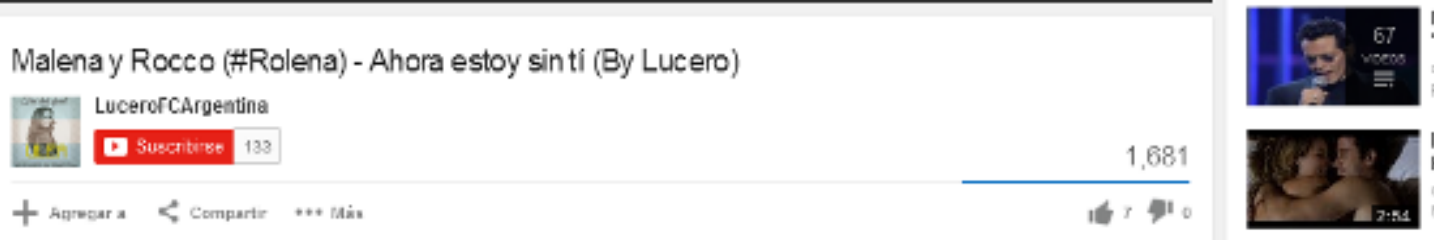

Rocco y Malena Un preso de tus labios:

Soda Stereo - Persiana Americana

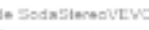

Swoumsodados pare b

Garc. Anthony - Y Hubo Alguen " HD

to esmadoses

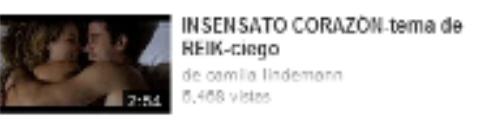

https://www.youtube.com/watch?v=gNtAOIKZF00

Se utiliza a los Facebooks como medios para publicitar y dar a conocer los videos musicales que realizan, invitando a la participación no solamente a través de la visualización del mismo, sino que también a la escritura de comentarios sobre dicho video. 
También son un espacio en el que no solamente se refleja el fanatismos de las audiencias/usuarios, si no que aparecen los detractores de la tira, que tienen un conocimiento sobre la misma pero están en contra de la tira, de la historia, los personajes, los actores, utilizando los Facebooks para descalificar la ficción a través de sus comentarios.

Esta clase de audiencias/usuarios hacen uso de las redes sociales para demostrar su disconformidad con la tira, importunar a los fanáticos, y en algunos casos realizar comentarios ofensivos hacia un actor o a un fanático.

En el Facabook oficial de Camino al Amor (https://www.facebook.com/TELEFECaminoAlAmor) un comentario ofensivo sobre la tira provoca una discusión entre las audiencias/usuarios. 
Vanesa embarazada ¿De Ángel?

Me gusta - Comentar - @CaminoAlAmorTw on Twitter - Compartir

A 92 personas les gusta esto. Mejores comentarios -

Escribe un comentario...

Nadia Escudero Es la peor novela del mundo roco y malena al igual que todos los que trabajan ahy son una por queria

Me gusta - Responder - hace 14 horas

Q. Jessica Juarez Anda pegate un baño Me gusta - $\$ 1$ - hace 11 horas

6. Camino al Amor Es IMPECABLE el trabajo de cada una de las personas que hacen Camino Al Amor, todo para que salga al aire lo mejor y puedan disfrutarlo desde sus casas. Nos quedamos con los miles de comentarios geniales que llegan. Igualmente gracias. Saludos. Me gusta - $\$ 5$ - hace 10 horas

Paola Daniela Montero Se ve que la miras xq sabes los nombres de todos ...

Me gusta - $\$ 3$ - hace 6 horas

S. Paola Ale Si no te gusta no la mires, ni sigas esta pagina Me gusta - $\$ 1$ - hace 5 horas

1. Chuuli Carp Qe hambre qe tienen! Son los unicos actores qe se reflejan tal cuaal son, son humildes como cualqieraa y tienen la mejor ondaa .. No como otros actores qe son una mierda de personaa $\mathrm{I} Y$ otraa no se metan con el trabajo de ellos al qe no le gustan tienen ocheenta canales mas para mirar $(-)$

Me gusta - 02 - hace 4 horas

Imagen del Facebook oficial de Camino al Amor (Noviembre 2014) 
La sucesión de comentarios que se generó a partir de una opinión en contra de la tira, despertó el fanatismo de las audiencias/usuarios, defendiendo la historia, los personajes, y los actores.

El constante cambio en la trama de la tira Guapas, y la consecuente incorporación de nuevos personajes, provocó numerosas críticas que inundaron todas las publicaciones en el Facebook. Sin embargo, surgió un debate acerca de la crítica constante hacia la ficción.

Ana Kalinka Cuenca Por que miran el programa si se la pasan criticando????

Me gusta - Responder - 19 - 30 de octubre a la(s) 0:13

Q.

Marile F. Dova es lo que me pregunto. (:) Me gusta - 2 2 - 30 de octubre a la(s) 0:28

Garcia Anibal de entrada estaba bueno pero desde hace un tiempo que van y vuelven con los ex y cansa, se repite todo cada semana. no la miran los editores ? la unica que todavia me divierte es el papel de ...no ninguna ni siquiera isabel macedo que esta mas que buena pero tambien me canso

Me gusta - 30 de octubre a la(s) 7:19

Auza Berta No concibo criticas, es inadmisible, teniendo el control remoto : simplemente cambien de canal y listo, pocas veces tendremos el privilegio de ver tanto talento junto. Gataflorismo argento infumable!!!

Me gusta - 33 - 30 de octubre a la(s) 8:16

Ana Maria Dunleavy Tal cual para que les sirve el control??? usenlo... Me gusta - 31 - 30 de octubre a la(s) 10:28

P2. Nicolas Antonelli jajajajjaja y si

Me gusta - 30 de octubre a la(s) 11:21

Silvina Goldman Lo que cansa es leer tantas quejas!!, Todas están muy bien en sus papeles, hasta Dalma que NI habla, NI actúa, pero estan todos muy bien....Al que no le gusta tiene otras opciones...No critiquen más!!!!

Me gusta - 30 de octubre a la(s) 21:35

Imagen del Facebook oficial de de Guapas (Octubre 2014) 
En determinadas ocasiones, los debates que se inician, surgen por un malestar provocado por una cambio en la historia de algunos personajes, o la aparición de nuevos actores, representando tramas nuevas. Sin embargo, todos los cambios bruscos que pueden desprenderse de una ficción, con motivo del bajo rating, o por la negación de algunos artistas para renovar sus contratos y continuar en la ficción, provocan fastidio entre las audiencias/ usuarios.

Son enriquecedores los debates que se producen cuando parte de las audiencias/ usuarios están molestos por algún manejo del argumento. En el lado opuesto se visibilizan los fanáticos que siguen en pie, apoyando a la tira, a un personaje o pareja de ficción, a pesar de cualquier cambio realizado. La unión de ambos polos permiten discusiones que propician reflexiones, explicaciones sobre lo que está ocurriendo en una tira y también predicciones sobre el rumbo que tomará la historia.

Otro elemento a destacar es como a través de Facebook se puede colaborar, aportar datos, cuando surgen dudas dentro del núcleo que conforman las audiencias/usuarios alrededor de las tiras. Como se resuelven a la brevedad por otras audiencias/usuarios, los interrogantes, inquietudes que se desprenden de una tira.

De este modo, se puede decir que las audiencias/usuarios crean ellas mismas un lugar dentro del Facebook oficial de una tira, que no es manejado por estas, pero que sin importar eso, pueden encontrar un espacio en el que se puede colaborar con el otro, atender sus dudas. Permitiendo observar cómo se apropian de una red social dada, y como construyen lazos entre las audiencias/usuarios. 
Roo Vane Barrios No entendi que es Reina en la historia? por que me perdi capitulos (:) y no entiendo nada.

Me gusta - Responder - 31 - 31 de octubre a la(s) 0:10

Marce Aguirre Reina aparece cuando mei quiere vender su casa y contrata una imobiliaria sin saber que reina es la dueña...y resulta q esta habia sido amiga de mei y las demas pero las estafo con un dinero y de ahi la odian todas...

Me gusta - 4 - 31 de octubre a la(s) 1:11

Roo Vane Barrios Aaaah ahora si, a nadie le pasa que se cortan los videos? Pense que era internet pero es el mismo programa que a ciertos minutos se corta.

Me gusta - 31 de octubre a la(s) 1:16

Roo Vane Barrios creo que escribi bien

Me gusta - 31 de octubre a la(s) 1:16

6. Sergio Pablo Dinatolo Parece ser que la tal Reina era amiga de todas y les dijo que pongan la guita en la financiera que quebró que es en ese momento cuando se conocen todas...sisi así de disparate el argumento, o sea la tal Reina está pegada con cinta Scotch vieja. Me gusta - 3 - 31 de octubre a la(s) 1:29

Imagen del Facebook oficial de Guapas (Octubre 2014) 
"Me muero de amor" \#Rocco \#Rolena

Me gusta Comentar-@CaminoAlAmorTw on Twitter-Compartir

IC A 119 personas les gusta esto. Mejores comentarios -

Escribe un comentario.

Vicky Garciia quien es rolena?

Me gusta - Responder - hace 17 horas

Camino al Amor Rolena es la combinación de los nombres Rocco y

Malena. ROcco+maLENA=ROLENA

Me gusta - 01 hace 12 horas : Editado

6. Vicky Garcila Aah! (:) gracias.

Me gusta - 01 - hace 12 horas

28 Escribir una respuesta

Cristina Botta Ro=rocco lena=malena

Me gusta Responder $\$ 2$ hace 16 horas

Lisa Godinho Santos Sooo good!!! $\bigcirc \bigcirc \mathrm{O}$

Me gusta Responder a 1 hace 7 horas

Imagen del Facebook oficial de Camino al amor (Noviembre 2014) 
Los lazos que se crean entre las audiencias/usuarios a partir del interés que despierta una determinada ficción es suficiente para que se perciba un despertar de emociones que provoca el agradecimiento a los autores de la tira, a las otras audiencias/usuarios que compartieron la ficción junto a ellas, que se interpelaron, debatieron, confrontaron y disfrutaron cada momento de la ficción.

La posibilidad de poder llegar a un lugar de ensoñación, identificación y fanatismo a partir de una tira televisiva, la capacidad de alejarse de los problemas cotidianos y lograr en una hora pensar o focalizar su mente en otro lado, el compartir cierta información sobre una tira, produce que la ficción se convierta en algo más que un simple producto televisivo. Permanece en sus memorias semanas, meses, años, no importa el tiempo específico, pero si interesa el recuerdo de una escena, un personaje o una pareja determinada.

El final de una tira es un momento destacable dentro de la misma, donde se mezclan las emociones por lo vivido, lo que generó la historia, la alegría y tristeza por saber cómo termina cada personaje, y la ensoñación al imaginar cómo continuaría la vida de cada uno de los personajes de la ficción.

Distintas mensajes de agradecimientos se desprendieron del final de la tira Farsantes y Dulce amor en sus respectivos Facebooks oficiales. 
Maria Laura Abella Gonzalez buena novela, ninguna como esta

13 de febrero a la(s) 1:01 - Me gusta

Divisual $\mathrm{Dg}$ ¡Felicitaciones, Farsantes! ¡Muy emotivo final! ¡GRACIAS Julio

Chavez por TANTO!!! GRACIAS, GRACIAS, GRACIAS!!! Volvé pronto a la TV, por

favor! Sos un GENIO!!! (:)

13 de febrero a la(s) 1:02 - Me gusta - m 2

Emmanuel Palacios Grafion Final conmovedor. Un fuerte aplauso para cada

uno de los actores que hicieron la tira, porque se lucieron

13 de febrero a la(s) 1:02 - Me gusta - 2

Patricia Venuti Sería tan hermoso poder ver y darle el ultimo abrazo y poder

desir que no hay un día que no pase sin recordarlo con Amor, enojo y ternura y preguntarle como seguir de ahora en mas. Eso momento nos dejaria con pazy tranquilidad en el corazón

13 de febrero a la(s) 1:02 - Me gusta - 31

Gabriela F. Valzacchi Te amo Ela!!! y sii, es asi, PEDRO Y GUILLE UNICO

AMOR... me revento q lo haya invitado a dormir, pero eso es la nada misma... ni dos palabras le dijo... Y no hay un solo dia en q no piense en PEDRO... Iloro mucho...

13 de febrero a la(s) 1:03 - Me gusta - 32

Patricia Venuti y Gracias Farsantes por hacerme emocionar, llorar y reirme Gracias

13 de febrero a la(s) 1:03 - Me gusta

Maria Manzur Gracias!!!! Julio Chavez, por esta ficción en televisión,( gracias también por El Puntero), fue un placer verte todas las noches. Y muy buen gesto de Benjamín Vicuna de estar en el final de esta historia, demostrando que el amor todo lo puede. Que buenos actores!!!!!!

13 de febrero a la(s) 1:04 - Me gusta - a 4

Imagen del Facebook oficial de Farsantes (Febrero 2014) 
Susana Lilián Gómez Me encantó el final!!! Felicitaciones a todos y gracias por brindarnos tan buenas actuaciones con tanto profesionalismo y entrega!!!! Excelente libro e impecable dirección!!

13 de febrero a la(s) 19:45 - Me gusta - m 3

Maria Fernanda Conti ESCENA TREMENDAMENTE EMOTIVA,

ACTORAZOS!!!felicitaciones!!!

13 de febrero a la(s) 20:21 - Me gusta - 32

Pichi Hilu LLORÉ

13 de febrero a la(s) 21:05 - Me gusta - @ 1

Laura Zonca Excelente final!!!! ACTORAZOS, me llore la vida con la escena final!!!! FELICITACIONES!!!!

13 de febrero a la(s) 21:27 - Me gusta - 31

Liliana Lopez Que Hermoso Abrazooo . Vamos Chaves

13 de febrero a la(s) 21:34 - Me gusta - 32

Liliana Lopez Chavez y Vicu

13 de febrero a la(s) 21:35 - Me gusta - 31

\%.

Angela Sanchez yo tambien queria abrazar a benjamin, terible final esperado, que se repita otra ficcion con estos gdes, pero que no se maten

13 de febrero a la(s) 21:50 - Me gusta - 32

Mabel Actis Caporale Solamente alguien que perdio a su ser amado, puede entender las palabras de Guillermo, toda la vida, todos los dias se recuerda a su ser amado...uno puede reacomodar su vida, hacer otras historias de amor, pero "ESA", esa historia, jamas se olvida...al menos es lo que me pasa hace 18 años...

13 de febrero a la(s) 21:57 - Me gusta - 32

Graciela Bello la mejor escena que vi en mi vida que actores un julio estupendo000000000000000000

13 de febrero a la(s) 22:23 - Me gusta - 34

Imagen del Facebook oficial de Farsantes (Febrero 2014) 
Mafalda Varela Julio Chavez, Benjamín Vicuña, Diego Velazquez, Alfredo

Casero, Chino Darín, Nico Repetto, Leonor Manso, Edda Díaz, Mario Pasik, Ingrid Pelicori, Julieta Zylberberg, Esteban Lamothe, Julieta Cardinali, Pilar Gamboa, Romina Richi, Vivian El Jaber, Pablo Cedrón. Facundo Arana y Griselda Siciliani, GRACIAS POR TAN EXCELENTE FICCION..........APLAUSOS DE PIE PARA TODOS UDS.

14 de febrero a la(s) 1:11 - Me gusta - 155

Dania Ruiz M. UNA GRAN FICCION: LA MEJOR HISTORIA DE AMOR DE LOS ULTIMOS TIEMPOS QUE ME ATRAPO DESDE EL 1 CAPTULO, AMARLOS... INTERPRETADA POR LA PAREJA PROTAGONICA MAS ACLAMADA POR MUCHOS, NO SOLO EN ARGENTINA SINO EN MUCHOS PAISES ALREDEDOR DEL MUNDO TRASPASARON LA PANTALLA $Y$ TRASPASARON FRONTERAS, LA DUPLA PERFECTA Y CON LA MEJOR QUIMICA QUE VI EN LA ACTUACION: BENJAMIN $V$. Y JULIO CHAVEZ 2 ACTORES DE LA OSTIA.. AUNQUE SEAN DIFERENTES UNO DEL OTRO POR SUS MATICES ACTORALES.. QUE GRANDES SON TALENTOSOS, PROFESIONALES, PERFECTOS Y MAGISTRALES. GENIOS Y FIGURA.... ESA ULTIMA ESCENA LA SACARON ADELANTE CON SU PROFESIONALISMO Y ME QUEDO CON ELLA.. TRISTE ES VERDA PERO SE VNIO ESAS LAGRIMAS Y EL DOLOR QUE PROYECTABA GUILLE QUE SIEMPRE SEGUIO $Y$ SEGUIRA AMANDO A PEDRO BEGGIO UN AMOR QUE TRANCIENDE MAS ALLA DE TODO HASTA DE LA MUERTE.... EL RESTO DEL ELENCO:

Facundo Arana, Alfredo Casero, Chino Darín, Nico Repetto, Leonor Manso, Edda Díaz, Mario Pasik, Ingrid Pelicori, Julieta Zylberberg, Esteban Lamothe, Julieta Cardinali, Pilar Gamboa, Romina Richi, Vivian El Jaber y todos los demas... APLAUSOS TAMBIEN...! USTEDES COMO ACTORES SON LOS QUE REALMENTE SE MERECEN EL RECONOCIMIENTO Y EL RESPETO DE PUBLICO QUE LOS SIGUIO DIA A DIA.."

14 de febrero a la(s) $2: 20$ - Me gusta - $B 4$

Adriana Dominguez EXCELENTE

14 de febrero a la(s) 9:57 - Me gusta - 133

Audrey E. Rocatti Una escena memorable!

14 de febrero a la(s) 10:08 - Me gusta

Irene Maria Fattore Buenisima Ficcion inolvidable Chaves

14 de febrero a la(s) 11:48 - Me gusta - $\$ 3$

Graciela Falcón GRososssssm

14 de febrero a la(s) 21:00 - Me gusta - $B 1$

Magda Garay todo lo que dijo guillermo es los que a me pasa con la perdida de daniel ayyyy cuanto dolor tengo como lo extraño cuanta falta me hace

14 de febrero a la(s) 21:53 - Me gusta

Imagen del Facebook oficial de Farsantes (Febrero 2014) 
Flopy Donnet la verdad qe muchas gracias dulce amoor,., los voy a extrañar espero que buelban alguun dia no dejen a la gente asii, los mire desde el peimer dia qe empeso qe exito tuvieron gracias por esas paciones, risas, locas cosas que asiaan para nosotros ya no se que voy a ser cada ves que me acostaba toda mi familia nos pasabamos juntos viendo a la gran novela DULCE AMOR suerte chicos chau los vamos a ree extrañaaar; ( 30 de abril de $2013 \mathrm{a} \mathrm{la(s)} \mathrm{1:05} \mathrm{-} \mathrm{Me} \mathrm{gusta} \mathrm{-} 34$

\section{Alicia Ciribello LOS VOY A ESTRAÑAR}

30 de abril de 2013 a la(s) 1:07 - Me gusta

Patiito Roldan me encanto el final!!!!!! estubo muy bueno $<3<3$

30 de abril de 2013 a la(s) 1:07 - Me gusta

Marita Montero hermosa novela no puedo dejar de llorar yyy ahora donde encuentro una historia tan linda ...gracias a todos por avernos regalado una novela tan interesante ...y aguante zampini y estebanez ....

30 de abril de 2013 a la(s) 1:10 - Me gusta - 32

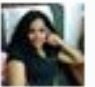

Miguelina Rosario la verda no lo esperabas fue muy lindo

30 de abril de 2013 a la(s) 1:12 - Me gusta

Jf Fz los quiero muchooo0 a todos!!!!!=(= gracias!!!!!

30 de abril de 2013 a la(s) 1:13 - Me gusta

1. Monica Cai ese beso noooo en final

30 de abril de 2013 a la(s) 1:13 - Me gusta

\section{Monica Cai graciiiiiassssss}

30 de abril de 2013 a la(s) 1:14 - Me gusta

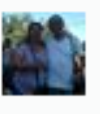

Noelia Ysaa Pereyra Todos embobados!!!!

30 de abril de 2013 a la(s) 1:26 - Me gusta - 31

2.

Ana Romina Madueño Muy bueno estuvo los felicito a todo el electo estuvo mamadera que la pasen otra vez

30 de abril de 2013 a la(s) 1:32 - Me gusta

Rosalia Quiñonez Gracias a todos, no pare de llorar, zampini genia total 30 de abril de 2013 a la(s) 1:32 - Me qusta

\section{Imagen del Facebook oficial de Dulce Amor (Abril 2013)}


Diversos modos de agradecimientos se publicaron a través de lo comentarios, de los videos musicalizados con canciones románticas, recreando el estilo de videoclip, de los mensajes escritos en las redes sociales que poseen algunos de los actores de las tiras. Diferentes formas de demostrar gratitud hacia lo que la ficción le brindó.

A partir de cada uno de los comentarios publicados se pueden dilucidar las distintas emociones y sentimientos que una tira puede provocar en las audiencias/usuarios, sumado a la multiplicidad de mensajes que se producen por segundo, hacen de este tipo de Facebook un espacio para visibilizar los sentidos que le otorgan a las tiras de manera constante.

El grado de exposición que tienen los comentarios fortalece los lazos que se crean y giran alrededor de una ficción, propiciando un espacio en el que el encuentro con el otro, y el conocimiento sobre las opiniones del otro es más fácil y rápido, debido a que está al alcance de las demás audiencias/usuarios de una tira.

Asimismo no debemos olvidarnos de los lectores ocultos, quienes no dejan huella de su lectura, pero que están permanentemente presentes, y que además les otorgan sentidos a una tira, pero que sin embargo deciden no exponerlos ante el resto de los seguidores de una ficción, en un sitio público como son las redes sociales dedicadas a una tira. 


\section{- INTERVENCIONES DE LAS AUDIENCIAS/USUARIOS EN FACEBOOK}

INTENTANDO PROVOCAR CAMBIOS EN EL DESARROLLO DE LAS TIRAS.

Dentro de la heterogeneidad de mensajes que publican las audiencias/usuarios, existen ciertos comentarios a través de los cuales reclaman cambios en la trama, en el horario, en las nuevas incorporaciones.

El fanatismo hacia una tira produce la creencia de un conocimiento total sobre las tiras, presuponiendo que nadie más que ellos las conoce completamente, y que esa capacidad les otorga una especie de derechos sobre ellas.

Esta clase de mensajes permite distinguir a un tipo de audiencia/usuarios competentes, que reflexiona sobre la tira que está mirando, creando un vínculo en el que se reconoce con la capacidad de reclamar y exigir cambios que beneficiaría a la ficción. Activando de este modo, una serie de competencias y saberes que creen poseer con respecto a una tira.

Por lo tanto, los comentarios funcionan como un medio para desplegar los conocimientos sobre la trama, el rol de los guionistas, las actuaciones y el perfil de los artistas seleccionados; al igual que la musicalización y la evaluación sobre la disposición de los programas televisivos del prime time. 
Los cambios en el horario de Guapas produjeron la disconformidad de los seguidores de la ficción Guapas, quienes realizaban reclamos sucesivos por el recorte en el horario debido a la llegada del programa Showmatch, con la conducción de Marcelo Tinelli.

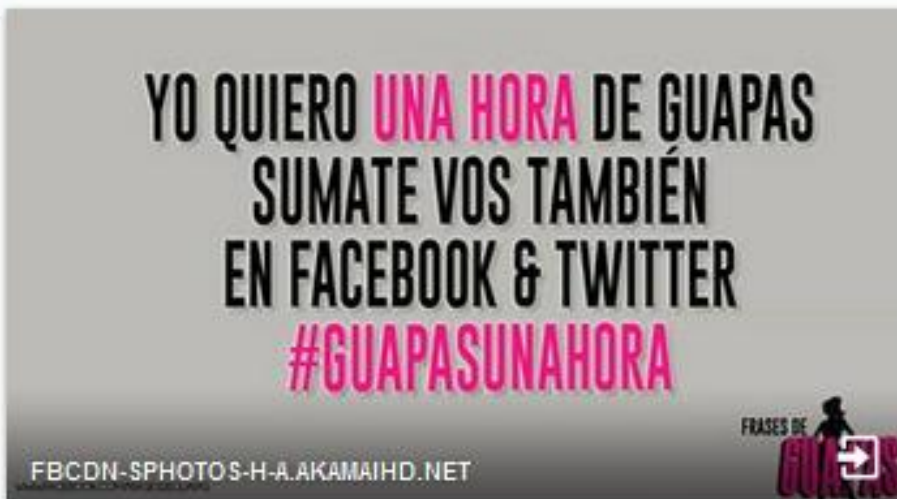

Me gusta - Responder : 2323 - 26 de abril a la(s) 23:31

Jennifer Bertonazzi Saquenle media hora a Tinelli y pasen Guapas una Hora!!!!!!

Me gusta Responder - 18 - 26 de abril a la(s) 21:50

Veronica Colman Amo a Donofrioo!!!

Me gusta - Responder $\triangle 18-16$ de abril a la(s) 19:10

Marcela Tántera Tinelli mas tarde y capitulos de Guapas mas largos!!!!!!

Me gusta Responder $\triangle 14$ - 12 de junio a la(s) 19:48

Maggie Truyol Quintana quedate $\infty$ donofrio mei!!!!!

Me gusta Responder 1914 - 28 de mayo a la(s) $17: 15$

Alicia Ines Guiñazu esas diferncias creo se soportan los priemeros tiempos, alguno debe cambiar y ser parecido al otro, de lo contario en algun momento se termina la relacion, la pasion pasa y la pareja debe sentir q se comparten otras cosas, gustos, modos etc

Me gusta 7 de agosto a la(s) $7: 29$

5] Daniela Diaz tinelli me recontra aburre ya fue!!!!!! siempre lo mismo000000000 Me gusta $\cdot B 1 \cdot 27$ de agosto a la(s) $23: 03$

D Ver más respuestas

.

Escribir una respuesta.

Mate de Luna Vamos Guapas por la hora ....nada de media hora!! Tinelli ya fue...termina guapas y cambio de canal ni loca miro este tipo y su programita mediocre..

Me gusta Responder $\Delta 14$ - 26 de abril $\&$ la(s) 0:14

Imagen del Facebook oficial de Guapas (Abril 2014) 
Ante el cambio de horario de la telenovela Dulce Amor, también se dio un debate entre las audiencias/usuarios, en el que algunos se mostraron conformes y otros estaban molestos por la modificación.

Beatriz Lucero A mi personalmente no me gusta el nuevo horario perder el reiting q tenia ․ㅡㄹ

4 de enero de 2013 a la(s) 12:34 - Me gusta

Mónica Pintos Que Bueno를

4 de enero de 2013 a la(s) 12:35 - Me gusta

2. Antonia Scorza la novela se puso buenisima y el cambio de horario es genial, gracias poe escucharnosss

4 de enero de 2013 a la(s) 12:42 - Me gusta - B3 3

Gisela Recchimuzzi No nos escucharon䓙 El cambio d horario, como televidentes, ya lo hemos pedido hace mucho tiempo atrás, pero lamentablement la nueva novela Mi amor, Mi amor, no tuvo éxito, así q la cambian d horario para luego levantarla, entonces no qda otra q mover Dulce amor a otro horario y dejar q lo q no se ve, lo q no tiene raiting para lo más tard posible. No seamos ilusos (6)

4 de enero de 2013 a la(s) $12: 55$ - Me gusta

1.8. Cecilia San Buenisimo

4 de enero de 2013 a la(s) 12:56 - Me gusta - $\$ 1$

F. Fernando Ariel Sosa estuvo m7uy bueno creeo que es la novela mas linda que vi en mi vida amo dulce amor

4 de enero de 2013 a la(s) 13:01 - Me gusta - $\mathbf{B} 2$

Victoria Luna q divertido

4 de enero de 2013 a la(s) 13:07 - Me gusta

6.) Pam Biaggini Hoooooo! Va antes o despues de Mi amor mi amor? No me guta quiero0000 dulce amooor.. Segun internet natacha viene con un baby de julian 4 de enero de 2013 a la(s) 13:25 - Me gusta - $\mathbf{B} 1$

Fati Echevarria Siiiii $x$ fin temprano aca en uruguay empezaba 12:25 y terminaba 1:30 era imposible mirarla ahora comenzara 23:15 mejora bastante 4 de enero de 2013 a la(s) 13:25 - Me gusta - B2

Imagen del Facebook oficial de Dulce Amor (Enero 2013) 
Las evaluaciones que se producen sobre el horario de una ficción, si es correcto o no, el pedido/sugerencias de prolongar el horario de una tira, modificando el horario del programa de tv que la sucede, demuestran la posición en la que se instalan las audiencias/ usuarios, desplegando los conocimientos que creen poseer a partir de la dinámica que se genera cuando se consumen las ficciones televisivas, reconociendo las competencias que tienen, por ejemplo para saber la duración conveniente de una tira dentro de la grilla horaria de un canal de televisión.

Con respecto a los cambios de la trama de las tiras, la disconformidad se transmite a través de los mensajes, que en algunas ocasiones terminan en reclamos, como una especie de campaña para demostrar el malestar.

En la tira Guapas propusieron una iniciativa de dejar de mirar la tira un día determinado, como forma de protesta a las nuevas incorporaciones, y a los consecuentes cambios en la historia. Además, los mensajes recurrentes a los guionistas no se hicieron esperar. 


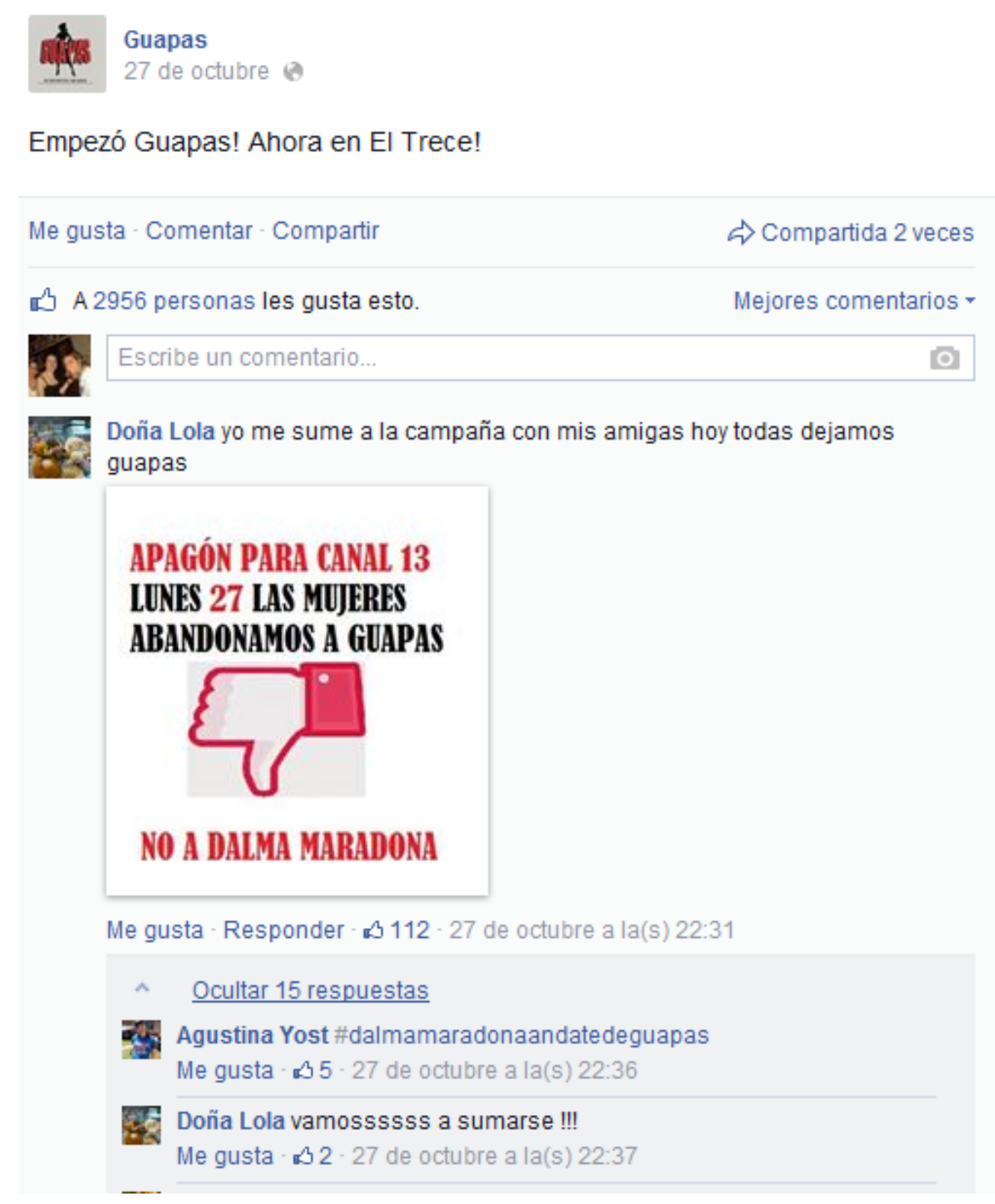

Imagen del Facebook oficial de Guapas (Octubre 2014) 
Agos Bisio DIGANME QUE LOS VERDADEROS GUIONISTAS DE ESTA SERIE DEJARON DE LABURAR hace un mes y medio.. DIGANMELO. NO se como pudieron ARRUINAR una serie genial de esta forma, es la unica novela con la que me enganché y ahora directamente no puedo ni mirar las propagandas... COMO hicieron para arruinar todos y cada una de las historias y los personajes? La historia de Andrea era buena y ahora es totalmente ilógica, un tipo que toda la vida cuidó a su mujer como oro, posesivo, padre de familia, estructurado.. de un día para el otro incorpora a la flia al amante de su mujer??? Quien carajo escribió eso? Da verguenza ajena mirarlo. UNA PENA. me imaginaba todos los martin fierro para Guapas en el 2015, pero ahora de verdad ojala no se lo ganen ni en pedo, no se lo merecen, por haber querido seguir ganando guita, en vez de seguir creando eligieron seguir lucrando. MALA desición; no cuidan ni al publico, ni a las actrices que estan siendo repudiadas por un monton de personas, del mismo publico que las veneraba y las admiraba por hacer personajes buenisimos.. HOY ODIABLES.

Me gusta - Responder - 4 - 15 de octubre a la(s) 22:52

Macarena Jurado Bastaaaaaaaaaaaa! Por favor!

Me gusta - Responder - a 4 - 15 de octubre a la(s) 11:17

Pauli Gonz Mey hija de dios, eso es increíble lo q se deja hacer. Horrible y

claudia es mas siniestra q falcon

Me gusta - Responder - 3 3 - 15 de octubre a la(s) 14:20

Maria Pachanita Esta cansando Guapas y es una pena porque empezo

bien.Hay personajes que te pudren como el " maricon " de Falcon ya me canso ademas esta mas loco, en cualquier momento mata a medio elenco jajaja y se convierte en un asesino serial jajaja

Me gusta - Responder - 3 - 15 de octubre a la(s) 13:10

Merly Rodriguez Ya. Esta. Aburrido00000

Me gusta - Responder - 3 - 15 de octubre a la(s) 12:35

Ameris Torres Roveres Pero siiii q se dejen de joder... aguante el doc! Me gusta - Responder - 3 - 15 de octubre a la(s) 11:31

Emilce Lilian Alvez si es verdad todos bancamos la novela desde el primer dia Pero las idad y venidas de Laura y Pablo ya cansan que Laura deje de hacerse de ser tan martil y se ponga las pilas con Pablo

Me gusta - Responder - 3 2 - 16 de octubre a la(s) 0:05

Beatriz Esther Kuj Por favor hagan algo esta insoportable la tira .desangelada

Imagen del Facebook oficial de Guapas (Octubre 2014) 
En algunos casos, por motivos personales, laborales, algunos actores protagónicos deciden abandonar la tira antes de tiempo, terminando con sus personajes y en consecuencia con la historia romántica que representaban con otro artista dentro de la ficción.

Estos cambios abruptos en el desarrollo de la trama provoca un quiebre entre las audiencias/usuarios quienes no se resisten al cambio, y por lo tanto deciden debatir, opinar y discutir sobre dicha situación.

Un personaje en particular, una historia determinada puede llegar a despertar el placer, un lugar de ensoñación inusitado, a través del cual las audiencias/usuarios manifiestan una especie de derecho de propiedad sobre la tira, creyendo que nadie como ellos pueden saber cómo repercutirá la ida de un personaje dentro de la tira.

El interés sobre las diferentes áreas de producción que conforman una ficción, desde los guiones, actuaciones, musicalización hasta las alteraciones en el rating, permiten crear en sus imaginarios un falso poder, el poder de ser escuchados, de ser leídos, de reclamar cuando lo consideren necesario.

En la telenovela Dulce amor, una de las parejas protagónicas estaba conformada por la actriz Calu Rivero (Natacha) y Juan Darthes (Julián). Seis meses después de haber comenzado la tira, Calu Rivero se fue a estudiar a Estados Unidos por dos meses, pero a su regreso decidió no continuar con la tira.

Si bien al principio, se pensaba que retornaría a la tira, y los fanáticos estaban al tanto de que había adelantado la grabación de varias escenas para que no se notara su ausencia, el tiempo transcurría, y no solamente no volvía a la ficción, si no que empezó a trabajar otra actriz Florencia Ortiz (Gisela) convirtiéndose en la pareja de ficción de Juan Darthes. 
Laura Dinesen Muy típico de novela de Estevanez, cuando empezó esta novela pensé que podía haber una buena historia pero sabiendo de dónde venía... el tipo no cambia, el tipo es un mercenario que estira las novelas a cualquier precio con un desprecio total por los actores y el público, desvirtuando totalmente los planteos iniciales, cayendo en los mayores disparates, a sólo modo de ejemplo se acuerdan de los últimos tiempos de "Amor en custodia"... hacía mucho tiempo que no veía una novela suya, empecé a ver esta y bueno... hace muchos meses que la dejé de ver.

15 de enero de 2013 a la(s) 23:04 - Me gusta - 32

Maria Patricia Decaria quiero que vuelvas natacha se te

extrañaaaaaaaaaaaaaaa

15 de enero de 2013 a la(s) 23:08 - Me gusta

Fabiana Soraire uhhh quiero q vuelvas y estes con julian ja

16 de enero de 2013 a la(s) 0:00 - Me gusta

Lucia Echaniz Natacha fue la más viva de todos acá, se fue en el momento preciso, y en el capítulo justo, una genia, Calu no se incendia.

16 de enero de 2013 a la(s) 0:45 - Me gusta

Nancy Marianetti Hermosa, se te extraña en la novela, volveeeeeeeeeee, porfi, sos muy bella y muy buena actriz besos

16 de enero de 2013 a la(s) 8:56 - Me gusta

Pamela Lima te extraño natu

16 de enero de 2013 a la(s) 14:30 - Me gusta

Anii Figueroa bolbe natu

16 de enero de 2013 a la(s) 19:32 - Me gusta

Alicia Benitez mealegro mucho mucho volve con tu amor

16 de enero de 2013 a la(s) 20:00 - Me gusta

Yanina Morales volve nataya con julian por favor!!!! era la pareja que mas me gustaba!

17 de enero de 2013 a la(s) 0:06 - Me gusta

Imagen del Facebook oficial de Dulce Amor (Enero 2013) 
Vanina Amaya Que aburrida que esta la novela...

5 de febrero de 2013 a la(s) 20:53 - Me gusta - 31

Ari Sequeira q vuelva natachaaaaaa :7

5 de febrero de 2013 a la(s) 20:57 - Me gusta

Graciela Bianchi Dejencen de joder!!!! Que vuelva la bambi....saquen a está falsa del medio....

5 de febrero de 2013 a la(s) 21:13 - Me gusta - 32

Soledad Ortiz me gusta mas que todo juan DARTES

5 de febrero de 2013 a la(s) 21:18 - Me gusta - 31

37 " Mariana Peñaloza Natacha ya fue, hace meses que Calu "abandono" el barco, Dejo colgado a Juan que perdio con su caprichito de irse. AHORA QUE SE VAYA A FREIR CHURROS pero por favo000000rrrrrrrrr que le busque pareja a Julian y le den una historia !!!!!!!!!! Es injusto que Juan pierda por culpa de no tener su historia de amor. No me disjustaria que se quede con Gisela (despues de todo era su novia) PERO DENLE A FONDFO CON LA HISTORIA!!!!!!!!! Ponganke un poco de temperatura a la pareja para no desperdiciar a DARTHES POR FAVOR!!!!!!!! Si Natacha murio a enterrarla y a seguir adelante que Julian sigue estando y necesita historia.

5 de febrero de 2013 a la(s) 21:38 - Me gusta - 32

Mariana Peñaloza Y convengamos que CALU RIVERO decidio abandonar la novela, a sus compañeros y a sus fans asi que de mi parte ya murio. Si no le importo nada del programa a mi menos me importa de ella ....que siga donde esta y de mi parte esata muerta y enterrada. HACE MUCHOS MESES QUE SE FUE ${ }_{\text {..., }}$ YA ES HISTORIA ANTIGUA. Seria horrible que vuelva en el ultimo capitulo y cierre su historia con julian asi de la nada....si le importo un pomo Julian y lo abandono y nii se comunica con el . Caprichos de principio a fin , No es suficiente mujer para Julian,

5 de febrero de 2013 a la(s) 21:41 - Me gusta - 34

Vicky Gorosito no me gusta la pareja de julian y gisela,que vuelva natuuuu 5 de febrero de 2013 a la(s) 21:59 - Me gusta

Maximiliano Silveyra quiero natu y julian no ella

5 de febrero de 2013 a la(s) 22:00 - Me gusta

\section{Imagen del Facebook oficial de Dulce Amor (Febrero 2013)}


Numerosos rumores surgieron ante el silencio de la actriz y del productor general de la tira, Quique Estevanez, sobre las dudas si continuaría en la tira, hasta que finalmente el productor reconoció la desvinculación de la actriz, quien había dejado grabada una escena con Juan Darthes, que se transmitiría en el final de la ficción, y que mantenía en vilo a los fanáticos por saber si Natacha continuaba o terminaba definitivamente su relación con Julián.

A sí mismo, en el Facebook Oficial de la ficción, una de las publicaciones oficiales era la pregunta ¿Se encontrarán Julián y Natacha?, a unos días de que la ficción finalice. 
Dulce Amor Oficial

25 de abril de 2013

\section{¿SE ENCONTRARÁN JULIÁN Y NATACHA?}

Me gusta - Comentar - Compartir

๔3 $\mathrm{A} 5410$ personas les gusta esto.

Ver comentarios anteriores
ه $5410 \square 1630 \Leftrightarrow$ Compartida 57 veces

50 de 1630

Lókáá Qúéti seguro que si pero quiero que se quede con Gise

27 de abril de 2013 a la(s) 10:41 - Me gusta

Natalia Carrizo siii p.mii se encuentran y van a volver a estar juntooos.poorque me gusta el papel q.hace ella...

27 de abril de 2013 a la(s) 11:37 - Me gusta

9. Yanii Gardiman no no se encuentran xq nose q productora no la dejó q salgan los capitulos q ella ya habiaa grabado ya para el final, asi q julian se queda con gisella aunq la verdad q la pareja q hacia $\mathrm{cm}$ natasha era unica mucha quimica la q se vaya del programa ella cago parte de la novela para mi 27 de abril de 2013 a la(s) 11:50 - Me gusta - 31

Katherine Barrios para mi tendrían que quedar juntos, y sino desepcionaria a mucha gente que dedico 1 hora durante mas de un año a soñar con esta novela 27 de abril de 2013 a la(s) 12:03 - Me gusta

Matias Zabalo ojala

27 de abril de 2013 a la(s) 12:09 - Me gusta

Yulii Cardarella Siii Onjalaa Dulce Amorr

27 de abril de $2013 \mathrm{a} \mathrm{la(s)} \mathrm{12:23} \mathrm{-} \mathrm{Me} \mathrm{gusta}$

A. Agustina Bratzie si, maldita gisela y la ,ay me sacaa

1.. 27 de abril de 2013 a la(s) 12:49 - Me gusta

Samu Silman siiiiiiiiii todos los finales son a si

27 de abril de 2013 a la(s) 13:46 - Me gusta

Imagen del Facebook oficial de Dulce Amor (Abril 2013) 
Dulce Amor Oficial

25 de abril de 2013 e

¿SE ENCONTRARÁN JULIÁN Y NATACHA?

Me gusta - Comentar - Compartir \$5410 ص1630 $\Rightarrow$ Compartida 57 veces

đ $\mathrm{A} 5410$ personas les gusta esto.

Ver comentarios anteriores

Vivi Barrera se encuentran,pero no quiero q terminen juntos, natacha ya

fue..pobre gisela no da q la deje de nuevo...aguante gisela y julian

26 de abril de 2013 a la(s) 1:09 - Me gusta - m 3

10

Rocio Castellano Ojalá q no. Natasha lo dejó ir. Y se escapó. Que se quede

con gisela que lo re banco siempre y lo ama de verdad $<3$

26 de abril de 2013 a la(s) 1:09 - Me gusta - 32

Matias Becheran Seria raro que vuelva con natacha... que es lo que

probablemente todos los televidentes queremos ! Pero seria mejor final para esa historia que esten juntos que nada ni nadie pueda borrar ese amor que sintieron que quedo en la nada de un dia para el otro por culpa del destino.

26 de abril de 2013 a la(s) 1:10 - Me gusta - 31

1. La Morocha Romero Romero Si julian vuelve cn natacha

26 de abril de 2013 a la(s) 1:10 - Me gusta

Mai Fioramonti Nooo que no pase que julian se quede con gise porque ella se fue y lo dejo. Y gise ya sufrio anteriormente por gabriela :):

26 de abril de 2013 a la(s) 1:10 - Me gusta - 33

Rosana Fischer giselaaaaaaaaa

26 de abril de $2013 \mathrm{a} \mathrm{la(s)} \mathrm{1:10} \mathrm{-} \mathrm{Me} \mathrm{gusta} \mathrm{-} @ 1$

Carlos E Rocha julian se va y aparece junto con natacha en la india y gisella termina con barrios

26 de abril de 2013 a la(s) 1:10 - Me gusta - 33

Imagen del Facebook oficial de Dulce Amor (Abril 2013) 
Un hecho similar ocurrió en la tira Guapas, cuando la actriz Florencia Bertotti (Lorena) no renovó su contrato por compromisos laborales, y abandonó su personaje. En consecuencia también dejó su personaje el actor Mike Amigorena (Doctor Müller), ambos conformaban una de las pareja protagónicas.

Carina Garcia Coincido plenamente con Patricia Balestra... deben escuchar a la gente q elige las historias para pasar un rato lindo de desconección a los problemas!! Berttoti y Mike nos regalaban con sus interpretaciones algo único... sin ellos y con los cambios Guapas pierde su esencia. ..destruyen asi una ficción q podría quedarse en el recuerdo de la gente y hacer historia...no permitan una vez más q la recordemos con el odio de lo que pudo ser y no fue...

Desde España donde la sigo con mucho esfuerzo por la diferencia horaria y mucha gente de aquí la ve, un beso a toda esta comunidad de lectores q siente lo mismo... y una felicitación a los actores y actrices de Guapas... más guapos y geniales no pueden ser...

Me gusta - Responder - 32 - 5 de octubre a la(s) 8:59

Clau González Una pifiada mal!!...vamos a ser varios los q dejemos d seguir la tira

Me gusta - Responder - 32 - 5 de octubre a la(s) 2:21

Jessica Belén Si esta la retardada de dalma se termino guapas!!!

Me gusta - Responder - 32 - 5 de octubre a la(s) 0:58

Sabrina Martinez Por Diossss ojalá lean los comentarios ' NO PONGAN A

DALMA MARADONA PORRRR FAVORRR

Me gusta - Responder - 2 2 - 5 de octubre a la(s) 0:48

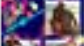

Norberto Gregorio no lo puedo creervan a poner a dalma, $\mathrm{x}$ favor esa piba es

SHed un desastre...aguanten las actrices como la gente ...la ponen a ella xq es hija de maradona....lorena lo mas...!!!

Me gusta - Responder - a 2 - 4 de octubre a la(s) 21:33

Judith Spernanzoni Terminen la novela no la arruinen. Maradona y estevez no

m gustan

Me gusta - Responder - ' 2 - 4 de octubre a la(s) 18:13

Debora Grasso Lorena volve !!!

Me gusta - Responder - 2 2 - 4 de octubre a la(s) 16:09

Silvina Ledesma No tiene sentido el personaje de Lorena estaba bien; cualquiera nunca piensan en el público.

Me gusta - Responder - m 2 - 4 de octubre a la(s) 15:28

\section{Imagen del Facebook oficial de Guapas (Octubre 2014)}


Sandra Cecilia Ameal para que escribimos si ni los leen y con la historia hacen lo que se les ocurre

Me gusta - Responder - 3 4- 12 de octubre a la(s) $23: 53$

Alejandra Liendro de Guglielmi

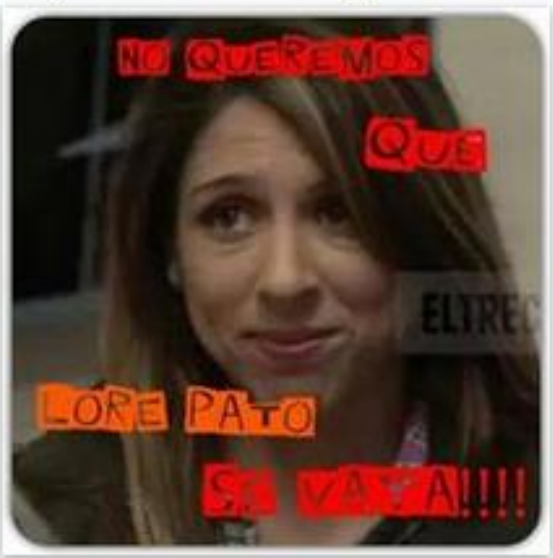

Me gusta - Responder - a 4-12 de octubre a la(s) 22:37

Isabel Carmen Greco sumen !!!!!!! no RESTEN !!!!!!!

Me gusta-Responder-a3 2-13 de octubre a la(s) 1:31

Marie Marie Borrajo Guilarducci jaja si es insoportable, no es lo mismo guapas sin lorena.

Me gusta - Responder - 31 - 13 de octubre a la(s) 18:39

Pura Kymica Betiana Acosta Cuando empiezan a salir los capos como lorena y el doc ya se pierde las ganas de mirar

Me gusta - Responder - 31 - 13 de octubre a la(s) 14:46

Pura Kymica Betiana Acosta Salio lorena de guapas? No miro mas! Y el doctor tamb dic q saldra... Asi no da

Me gusta-Responder a 1-13 de octubre a la(s) 14:45

Carina Garcia Volce lorena patoooo!! Y con el doccccc! ! La tira no vale nada sin ustedes!!!

Me gusta - Responder - 31 - 13 de octubre a la(s) 5:37

Imagen del Facebook oficial de Guapas (Octubre 2014) 
Los diversos reclamos que las audiencias / usuarios realizan a través de las redes sociales forman parte de un escenario digital que posibilita la visibilidad y propagación de múltiples mensajes que se exponen contantemente y que son retomados y apropiados por otros, es decir una época mediada por una divulgación a gran escala potenciada por el desarrollo tecnológico.

Sería erróneo considerar que algunos de estos mensajes no son leídos por los guionistas, autores y hasta actores de una tira. Sin embargo, esto no significa que las opiniones de las audiencias/usuarios marquen el rumbo de una ficción, o que problematicen determinados aspectos de la misma. Si son disparadores que no se ignoran, se conocen, pero no influyen en posibles cambios de la ficción.

El desacuerdo por los horarios en los que se transmite una tira, la salida e incorporación de personajes producen discusiones entre las audiencias/usuarios, las cuales llegan a tomar conocimiento gracias a la masividad que las redes sociales promueven, creando una ventana que está al alcance de otras audiencias/usuarios, la prensa, creadores de una tira. A pesar de todo, sigue existiendo una barrera entre los seguidores de una tira y los productores de la misma, barrera que parece más corta debido a la falsa proximidad, a la falsa cercanía que producen las redes sociales, pero que sigue presente.

Las redes sociales en esta instancia promueven nuevas prácticas y rutinas de interacción que puede llegar a generar la fantasía de un reconocimiento y aceptación de los cambios propuestos, no obstante existen otras audiencias/usuarios que reconocen que no disponen de la capacidad de provocar esos cambios, pero que encuentran en Facebook la posibilidad de sugerir, expresar, proponer nuevas ideas, constituyendo un espacio interesante en el que se reconocen como tal. 
Se establece una adaptación permanente de las audiencias/usuarios dentro de las redes sociales, haciendo uso de ese sitio de diversos modos, exponiendo distintas formas de compromiso y participación que están en movimiento. La relación entre las audiencias/usuarios y los Facebooks oficiales de una tira permiten observar las transformaciones de las prácticas llevadas a cabo, evidenciando un proceso que supone otras prácticas que surgen en la medida que aparecen nuevas herramientas digitales. 


\section{- IDENTIFICACIÓN DE AUDIENCIAS/USUARIOS CON SITUACIONES, PERSONAJES QUE SE DESARROLLAN EN LAS TIRAS.}

A partir de los Facebooks oficiales de una tira, se puede observar cómo una ficción permite alimentar necesidades asociadas a la identificación con una historia en particular, un personaje o una relación amorosa, con un flujo y velocidad característica de las redes sociales.

Las audiencias/usuarios no solamente producen debates, comentarios, opiniones en los Facebooks, sino que también a través de sus mensajes se puede analizar si existe algún tipo de identificación para con la tira que están mirando, si se producen reconocimientos a través de la identificación y proyección, procesos de comparación y discusión, entre otros; apropiándose de aquellas situaciones, personajes, temáticas en las que se reconocen como tal, y que los llega a motivar en algún aspecto.

Asimismo, se da lugar a una dimensión de goce, asociada con un placer de identificación con la ficción televisiva, placer que puede provocar la añoranza de una situación vivida o que se pretende vivir. La nostalgia, la emoción, la evocación de una anécdota en relación a momentos vitales de la vida. Sin embargo, también una ficción permite evocar el recuerdo de una situación negativa, trágica, produciendo dolor. En definitiva, el acto de la identificación no resulta neutro para las audiencias/usuarios, sino que implica en sí misma una valoración.

Una ficción televisiva aparece como un escenario en el que se inscribe historias personales, y funcionan como disparadoras, permitiendo la evocación de situaciones vividas, que marcaron o están marcando una etapa importante de sus vidas. 
En la tira Farsantes, en el momento que el personaje de Benjamín Vicuña (Pedro) muere de forma trágica, dando fin a la pareja que protagonizaba con Julio Chavez (Guillermo), se sucedieron diversos mensajes sobre el significado de la pérdida de un amor, cómo se continúa, si se puede rehacer la vida amorosa con otra persona.

Temas como la muerte, el dolor, la soledad, se evidenciaron en algunos de los numerosos comentarios que escribieron las audiencias/usuarios cuando la trama de la ficción provocó un vuelco inesperado.

Naty Magri El gran amor no se olvida nunca .... pero por cosas del destino a veces ese amor no puede quedarse en tu vida o lamentablemente como en el caso de Pedro se tiene que ir ! Y hay que seguir adelante aunque duela y si la vida te da una nueva oportunidad de ser feliz al lado de alguien más no hay que desaprovecharla !!!! Vamos Gulle por José

24 de enero a la(s) 1:49 - Me gusta - 35

Carola Dalil la muerte física no es el fin del amor por que verdadero amor puede estar por siempre en alma de la gente y esto es caso de guille que siempre va a amar a pedro y solo pedro. y jose sera solo copia barata, sombra del verdadero amor. y solo una person sin dignidad puede ser de acuerdo con esto por lo tanto donde esta dignidad de jose????

24 de enero a la(s) 11:04 - Me gusta - 38 
$\because \quad$ Candela Merlo Las personas que insisten con que el amor se da una sola vez en la vida, están cegadas por el fanatismo? Viven en un termo? Que el fanatismo no les haga perder la objetividad. Las personas pueden amar y dejar de amar. Los vínculos pueden nacer y disolverse. Así es la vida. Un poco de sentido de la realidad!!!

25 de enero a la(s) 22:12 - Me gusta - 34

Rena Ven Ay Candela Merlo Creo que las personas que insisten con su el fiscal están tratando de dar su visión de una realidad para la verdad objetiva. Que el fanatismo no les haga perder la objetividad. Cada tiene su opinion sobre el amor. El amor llega solo una vez en la vida o varias veces depende del significado que tenga el sentimiento llamado AMOR en tu vida.

El verdadero y único amor solo se encuentra una sola vez pero si lo sabes discernir entre todos los amoríos que te lleguen. Solo una vez amas con una intensidad extraordinaria. El amor no puede dividirse ps entonces sería amar y querer.

Cuando pierdes a un ser amado por las razones que sean,siempre intentas reponerte y darle la oportunidad a tu corazón de que se vuelva a enamorar y tal vez lo consigues pero si por casualidad, comparas te darás cuenta que nunca amas de igual forma y solo una te sacude y te estremece. Una palabra hay personas como fiscaleras que confunden el amor verdadero ( que llega solo una vez) con sexo, pasion, "quierer" y erc. por que estas personas no son capaces de tener sentimientos profundos

26 de enero a la(s) 3:30 - Editado - Me gusta - 36

Rena Ven Pobre gente que no entiende simpleces cosas que importante no estado "vivo o muerto" Io más importante es sentimientos y si no hay amor en corazon de un hombre, el nunca va a ser feliz aunque si al lado de el hay persona que el mas vivo en el mundo

6 de febrero a la(s) 11:55 - Editado - Me gusta - a 3 Gracias! 
Silvia Beatriz Castro Y el nudo en la garganta

que no se va..... Soberana actuación de los

protagonistas de FARSANTES!!!! En unas pocas

y sentidas palabras se habló del duelo y cómo

transitarlo.

Voy a extrañar esta cita de las noches.

12 de febrero a la(s) 23:56 - Me gusta - 35

Claudia Sanger Bien, cuidado... el dolor de una pérdida no pasa...no sana... solo se aprende a vivir con eso y a continuar la vida. Buen mensaje. Julio Chavez, sublime!. Y la música... excelente!. Con todo el boicot que tuvo esta serie, fue lejos, LO MEJOR DEL AÑ̃. Me saco el sombrero con todos los actores. Mario Pasik, Ingrid, Edda Diaz, Alfredo Casero, Esteban lamot, el actor que interpreto a José. TODOS. Insisto... digan lo que digan, si es jodido, si tiene mal caracter, si es esto 0 aquello, no me importa nada porque no vivo con él. CHAVEZ ESTA FUERA DE CONCURSO. ES SUBLIME.

13 de febrero a la(s) 0:13 - Me gusta - 17

Patricia Venuti Sería tan hermoso poder ver y darle el ultimo abrazo y poder desir que no hay un día que no pase sin recordarlo con Amor, enojo y ternura y preguntarle como seguir de ahora en mas. Eso momento nos dejaria con pazy tranquilidad en el corazón

13 de febrero a la(s) 1:02 - Me gusta - 31

Mabel Actis Caporale Solamente alguien que perdio a su ser amado, puede entender las palabras de Guillermo, toda la vida, todos los dias se recuerda a su ser amado...uno puede reacomodar su vida, hacer otras historias de amor, pero "ESA", esa historia, jamas se olvida...al menos es lo que me pasa hace 18 años...

13 de febrero a la(s) 21:57 - Me gusta - 32 
Magda Garay todo lo que dijo guillermo es los que a me pasa con la perdida

de daniel ayyyy cuanto dolor tengo como lo extraño cuanta falta me hace

14 de febrero a la(s) 21:53 - Me gusta

\section{Imagen del Facebook oficial de Farsantes (Enero - Febrero 2014)}

La conexión que se produce entre las emociones y los sentidos que acompañaron determinadas situaciones vividas en diferentes momentos, permite que a partir de ciertas escenas que ocurren en la ficción, se despierte o se reconozca una afinidad o comprensión en la conducta de los personajes.

Otro caso estudiado es el de la ficción Guapas, en el que los encuentros y desencuentros de la pareja protagonizada por Carla Peterson (Mey) y Alberto Ajaka (Donofrio) producen un reconocimiento en las audiencias/usuarios.

Alexia Pinolli el amor cuando es verdadero

nunca se pierde no me decepciones \#Donofrio

Me gusta - Responder - 39 - 18 de junio a la(s)

19:27

Patoo Luu tanto en el hombre como en la mujer pueden pasar varias personas por la vida de uno, pero cuando hay verdadero amor se sabe esperar de ambas partes!!!! y ahi hay amor mutuo!!!!

Me gusta - Responder - 34 - 18 de junio a la(s) $19: 53$

Sandra Gabriela una grosa!!! genial actuación , como nos identifica como mujeres este programa.

Me gusta - Responder - 32 - 19 de junio a la(s) 0:07 
Cecilia Bricka Que buena actriz! ! Muy

identificada con su personaje .. a veces nos

damos cuenta tarde de quien realmente vale la

pena. Donofrio un groso! !!

Me gusta - Responder - 10 - 19 de junio a la(s)

$0: 18$

Romina Noralí Rojas ella es una boluda!

mujere wake up!! todas tenemos un DONOFRIO

solo que algunas pocas lo valoramos y no lo

dejamos escapar!

Me gusta - Responder - 1 1- 19 de junio a la(s)

$21: 51$

Betty Caruso Las lágrimas de ellos duran

menos tiempo que las nuestras.

Me gusta - Responder - 19 de junio a la(s) 17:30

La Casa de Asterión lloramos por cada

gil...........y nunca nos enganchamos con un

Donofrio...para pensarlo chicas....JA

Me gusta - Responder - 21 de junio a la(s) 8:55

Alicia Ines Guiñazu esas diferncias creo se soportan los priemeros tiempos, alguno debe cambiar y ser parecido al otro, de lo contario en algun momento se termina la relacion, la pasion pasa y la pareja debe sentir q se comparten otras cosas, gustos, modos etc

Me gusta - 7 de agosto a la(s) 8:29

Imagen del Facebook oficial de Guapas (Junio - Agosto 2014) 
En la misma tira, se trató el tema de violencia de género hacia la actriz Mercedes Scápola (Natalia), por parte de su novio. Una escena dramática entre ella y su madre, Mercedes Morán (Mónica) logró conmover a las audiencias/usuarios, quienes revivieron experiencias personales.

Una emotiva conversación entre madre e hija, y una frase final dicha por la madre, que fue retomada por las audiencias/usuarios para sus reflexiones: "No hay nada que puedas haber dicho que justifique que te pegue. Eso está mal”.

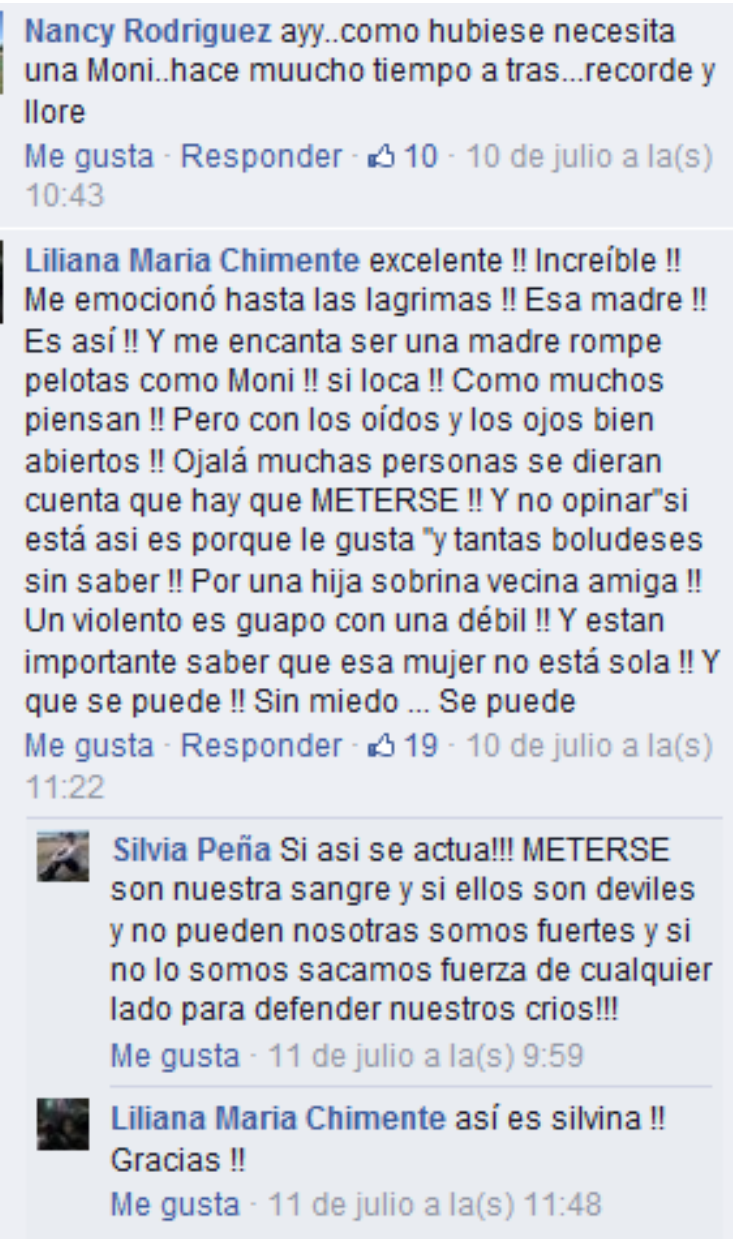

Liliana Maria Chimente excelente !! Increíble !! Me emocionó hasta las lagrimas !! Esa madre !! Es asi !! Y me encanta ser una madre rompe pelotas como Moni !! si loca !! Como muchos piensan!! Pero con los oídos y los ojos bien abiertos !! Ojalá muchas personas se dieran cuenta que hay que METERSE !! Y no opinar"si está asi es porque le gusta "y tantas boludeses sin saber !! Por una hija sobrina vecina amiga !! Un violento es guapo con una débil !! Y estan importante saber que esa mujer no está sola !! Y que se puede !! Sin miedo ... Se puede Me gusta - Responder - 19 - 10 de julio a la(s) 11:22

Silvia Peña Si asi se actua!!! METERSE son nuestra sangre y si ellos son deviles $y$ no pueden nosotras somos fuertes y si no lo somos sacamos fuerza de cualquier lado para defender nuestros crios!!! Me gusta - 11 de julio a la(s) 9:59

Liliana Maria Chimente así es silvina !! Gracias !! Me gusta - 11 de julio a la(s) 11:48 
Cristina Fanelli Hay otras clases de

maltrato..que te hagan laburar afuera y en la casa,te gasten o controlen tu dinero,que te rabajen,descalifiquen por lo que hacés o dejés de hacer...hay golpes en maltratos psicológicos,emocionales,económicos de rebajar o menospreciar que duelen más que una cachetada o un moretón....lo digo porque me pasó

Me gusta - Responder - 34 - 10 de julio a la(s) $17: 39$

Andrea Grimaux Muy bueno, ojala ayude, estos sicopatas, son todos iguales, yo lo puedo afirmar, fui una mujer golpeada, y es cierto, uno Io niega, es cierto uno piensa que es la culpable, y es cierto que por verguenza nadie lo cuenta, se produce un secreto familiar, doy gracias dios que hoy todo cambio! "No hay nada que puedas haber dicho que justifique que te pegue. Eso esta Mal"

Me gusta - Responder - 32 - 11 de julio a la(s) 23:34

Paola Carolina Giudice Cómo lloré con esta escena de la diosa de Merecedes Morán!!!! Me identificó mucho, porque si un tipo nos trata con violencia no es por nada que hayamos hecho, es un loco de mierda de quien uno debe alejarse. Me gusta - Responder - 32 - 10 de julio a la(s) 22:06

Gisella Echevarria Impresionante!! Mejor que cualquier publicidad que salga x tv 0 gráfica. Muy claro!!!! Ojalá lo hayas visto hace más de 30 años... y no hubiéramos pasado $x$ esto. Lástima. Pero nunca es tarde para aprender.

Me gusta - Responder - 10 de julio a la(s) 12:05

Imagen del Facebook oficial de Guapas (Julio 2014) 
El poder de la identificación supera cualquier pronóstico o perspectivas que puede llegar a tener un productor o autor de una ficción. Se produce o no se produce, dependiendo de múltiples variables que entran en juego dentro de una ficción. La identificación no se puede manejar, manipular, simplemente ocurre.

La posibilidad de poder evocar una situación vivida, más allá que haberla transitado puede implicar un balance positivo o negativo, destaca la capacidad de volver a recordarla, de despertar sentimientos olvidados o que se creían haber olvidado.

La identificación permite incentivar la autorreferencialidad. Los diálogos, las imágenes, la musicalización y la calidad de la actuación, es decir el clima logrado, son factores que influyen cuando se produce la identificación. Son elementos que caracterizan a una tira en el momento de referenciar contenidos ajenos.

Las escenas mencionadas son solo una muestra de los diversos acontecimientos mayormente autorreferenciados que conforman una ficción. En este caso la cantidad de comentarios, opiniones, reflexiones que se propagaron sirvieron para evaluar el grado de identificación hacia un personaje o situación particular.

Cuando una escena logra traspasar la pantalla y conmover a las audiencias/usuarios, el carácter propio de la ficción se ve enriquecido. La identificación produce una predilección por el argumento de la ficción, aunque esto se pueda o no reflejar en el rating. Desde la perspectiva de las audiencias/usuarios, el reconocimiento por una tira está por sobre cualquier valoración cuantitativa.

En este sentido, las nuevas tecnologías favorecen el desarrollo de la propagación de mensajes que demuestran un autorreconocimiento, otorgando la posibilidad que otros puedan leerlos y animarse a expresar su motivo de identificación.

Si bien la identificación es una dimensión constitutiva de cada ficción previa al avance de la tecnología, las redes sociales posibilitan un marco de visibilidad, tendiente a incitar a comentar, a escribir, a expresar sus sentimientos con más naturalidad y menos prejuicios. Por lo 
tanto, es necesario destacar que las posibilidades de acceso y conocimiento de otras realidades vividas, son un elemento característico de las redes sociales, que definen el modo de participación en relación a una tira.

El Facebook sobre una tira permite la constitución de modos de identificación relacional, en el que se observan redes de pares, de otras audiencias/usuarios que vivieron situaciones similares, y que son capaces de expresar sus sentimientos, que redescubrieron a partir de una escena determinada. 


\section{- ESTRATEgIAS DE COMUNICACIÓN QUE UTILIZAN LOS CANALES DE}

TELEVISIÓN A TRAVÉS DE FACEBOOK PARA CON SUS AUDIENCIAS/USUARIOS.

A partir de la evolución de las tecnologías digitales, la industria televisiva y los productores de contenido desarrollaron diversas estrategias comunicacionales con el propósito de atraer a las audiencias/usuarios, potenciando la participación de ellas, y la difusión de los productos que realizan.

La convergencia mediática posibilitó el desarrollo de audiencias/usuarios que eligen, opinan; modificando la manera en que se consumen los medios al igual que las formas en que ellas se vinculan a través de las redes sociales. Se piensa en un contenido para ser consumido en diferentes plataformas, destinado a audiencias/usuarios que consumen y participan del contenido en cuestión.

A pesar de que la digitalización permitió la interconexión de audiencias/usuarios con multipantallas, incrementando su actividad, participación, no debemos olvidar que este escenario deslumbrante está orientado por multimedios regidos por intereses económicos que prevalecen ante todo.

Los Facebooks oficiales de una tira son diseñados y administrados por el equipo del departamento de tecnología de un canal de televisión. En los diferentes Facebooks recorridos en el período de tiempo que dura la investigación, pude encontrar similitudes entre el canal Telefe y El trece Tv en cuanto a una tira.

La permanente utilización de fotos de una escena en particular, de los artistas en el backstage, los bloopers de las grabaciones, los saludos de los actores o actrices agradeciendo a sus fanáticos, los festejos de cumpleaños de los integrantes del elenco dentro del set de grabación, las imágenes de la celebración cuando traspasan los 100 capítulos emitidos o más, son una 
constante en el Facebook oficial.

Asimismo, se intenta mostrar a algunos de los artistas más allá de los personajes que interpretan, en un contexto cotidiano, relajado, realizando alguna actividad pero por fuera de sus tareas en la ficción, como por ejemplo en una participación a eventos, una sesión de fotos.

La publicación del capítulo completo también es habitual. Sin embargo, el momento en el que es subido en la red social, varía de acuerdo a cuándo es entregado por la productora, especificó a través de una comunicación telefónica, Esteban Raffo Quintana, el Gerente de Plataformas Digitales de Telefe; debido a que en algunos casos el capítulo se termina de editar unas pocas horas antes de salir al aire, o los últimos bloques en el momento de la transmisión. Si bien Raffo Quintana afirma que lo ideal sería que estén disponibles ni bien termina de emitirse, no siempre se llega con los tiempos.

La creación de resúmenes semanales de las principales escenas de la ficción de fotos o videos, están destinadas no solamente a quien no pudo ver la tira sino también aquellos que desean revivir los momentos trascendentales de la historia.

Si bien se utilizan recursos como preguntas sobre qué ocurrirá con una escena, qué sucederá con algún personaje, y se escriben múltiples comentarios, se producen debates, discusiones, no hay intervención visible desde la administración. Igualmente, es necesario aclarar que esto no significa que no se produzcan intervenciones de usuarios fantasmas para compensar, moderar opiniones, o cambiar la orientación del debate que se está generando.

Al mismo tiempo, el Facebook es utilizado, según Esteban Raffo Quintana, con el fin de promocionar la tira, dar un adelanto a través de un banner con las imágenes de los protagonistas y una frase provocadora o generadora de expectativas por mirar el próximo capítulo.

El uso y apropiación del Facebook oficial de una tira, permite confundir la fascinación de 
la participación, de formar parte de una comunidad dedicada a una tira específica, con la ilusión de la mera visibilidad. Las audiencias/usuarios se sienten parte, son miembros de un Facebook específico, y esto se debe a las diversas estrategias implementadas para seducirlas permanentemente, incentivando su participación y permanencia.

El desenlace de una tira, es uno de los momentos que genera más expectativa entre las audiencias/usuarios, que derivan en tensiones, debates y opiniones que promueven y aceleran la participación. Dicho contexto es aprovechado por la industria, que estimula a las audiencias/usuarios con preguntas, encuestas, consultas, sobre el final de la ficción.

En la tira Dulce Amor, después de finalizar el anteúltimo capítulo, se publicó la pregunta sobre cómo finalizará la tira. Produciendo exaltación, curiosidad entre los fanáticos. Permitiendo que también se expresen sobre posibles finales, o sobre cómo soñarían ese final, marcado por diferentes emociones que despierta una ficción que despertó el fanatismo entre las audiencias/usuarios.

Diversas expresiones impregnadas de diferentes sentimientos, se sucedieron en el Facebook oficial, convirtiendo a dicha publicación en una de las más comentadas entre los fanáticos de la tira. 
¿Les gustó el capítulo? ¿¿Cómo creen que termina??

Me gusta - Comentar - Compartir B7926 $\square 1460 \Leftrightarrow$ Compartida 37 veces

A 7926 personas les gusta esto.

Ver comentarios anteriores

50 de 1460

Barbara M. Rivero no

27 de abril de 2013 a la(s) 3:22 - Me gusta - $\$ 1$

P. Maria Victoria Toyos El capítulo buenisimo. mi opinión es que tiene que terminar Vicky con Marcos con hijos, Brenda con Lucas, Julián con Natacha, Flor con Benja y Diego, Lorenzo y Angi presos o en el loquero, Bruno con Maite, Gisela se va, Pepe con Elena, Isabel con Zomoza, Máquina y Coni con hijos, el terco con la mamá de Lucas, Gabriela sola con Nano, Ciro se va de viaje con la mamá, Barrios preso, Emilio con su gran amor Cris. BUENISIMA LA NOVELA.

27 de abril de 2013 a la(s) 4:51 - Me gusta - B5

Y030 Mayra Villamayor el mejor capitulu para mi se descubre q lorenzo mato a montalvan termina preso y todos felices esta buenisima la novela espero q den la segunda parte

27 de abril de 2013 a la(s) 10:29 - Me gusta - $B 1$

15. Juliana Brent ¡Brenda con Ciro...! (Lucas solo la hizo cornu....) Pero sabemos como se manejan los telenovelone... Nada distinto.

27 de abril de 2013 a la(s) 10:59 - Me gusta - $\mathbf{B 2}$

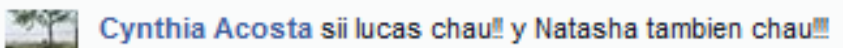

27 de abril de 2013 a la(s) 11:23 - Me gusta - $\$ 2$

Sofi Iglesias termina que Julian se queda con Gisela, Brenda con Ciro, Elena con Pepe, Lorenzo preso y Angeles libre porque escapa, Barrios quiere escapar pero lo detienen

27 de abril de 2013 a la(s) 11:55 - Me gusta - $\$ 2$

Lore Rojas Termina como se conocieron. Marcos con Vicki obvio, Natasha con

Julian y Brenda con Lucas.. Los demas presos o muertos jeje

27 de abril de 2013 a la(s) $12: 17$ - Me gusta - $\$ 1$ 
Romina Rodriguez la mejor novela en el año!l

26 de abril de 2013 a la(s) 11:51 - Me gusta - $\$ 1$

0 Danii Palù que pasa con lucas ? yo creo que brenda lo tiene que perdonar y natalla que se muera porq gisela ya es de julian la hizo sufrir una vez cuando eran jovenes ahora no da que la vuelva a lastimar.... ella se fue qe se joda. Marcos seguro tiene un hijo con victoria y lorenzo tiene que morir (:)

26 de abril de 2013 a la(s) 11:52 - Me gusta - B4

Celina C. Aguirrez me encantooo

26 de abril de 2013 a la(s) 11:54 - Me gusta

Marta Mallmann pienso lo mismo que carolina moreyra son las parejas ideales

O

26 de abril de 2013 a la(s) 11:55 - Me gusta

Luly Barrionuevo QUIERO VERLOOOOO

26 de abril de 2013 a la(s) 12:03 - Me gusta

Antu Ailen Carp Si me encanto cuando lorenzo estaba el la oficina y lo veia montalvan .creo $\mathrm{k}$ termina en $\mathrm{k}$ victoria y marcos ya tienen su casa y tienen hijos 26 de abril de 2013 a la(s) 12:04 - Me gusta

Pamela Recabal Esta definido que en 2015 se hace la 2da asique mucho no espero mas que la aparicion de natacha cara a cara .

26 de abril de 2013 a la(s) 12:04 - Me gusta

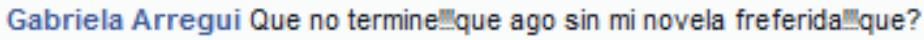

26 de abril de 2013 a la(s) 12:05 - Me gusta

Antu Ailen Carp Y lorenzo va preso no angeles

26 de abril de 2013 a la(s) 12:05 - Me gusta

6. Marisa Mariscal Bertelli julian le dice que ama a gisela..aunque me parece q se va y julian rechaza a natacha y queda solo y la loquita de gaby lo gana..lucas arrepentido..no creo q brenda lo acepte $\mathrm{xq}$ ciro es mejor persona..se queda con el..lucas solo con flor de amigosss y marcos o viky algun herido mas tiene $q$ haber..lorenzo con angelles presos o en cotolengo..pepe con elena si segurooo...es el maestrro del chocolate..todos trabajando..pero en dulce amor..el amor de los adultos prevalece en la locura de los jovenes por el sexo..es decir, ,pepe-elena-marcos-viky...juntos...los otros por pensar mas con la de abajo..no es amor verdadero..nooo..en el aire..lastima gisela me parecio buen su roßy no gaby q aunq se arrepintio hizo mucho daño-julian por ser adulto se comporto como lucas hermos0000 1 idULCE AMOR

26 de abril de 2013 a la(s) 12:05 - Me gusta - B4 
Gisela Maina Buenisimo el kpitulo! espero q no termine cmo todas...q se ksan y tienen hijos xfa no! Jaja. $Q$ sea un final diferent! $Y$ q nos djen $c n$ la intriga q lorenzo y angi se vayan asi algun dia continua!

26 de abril de 2013 a la(s) 2:02 - Me gusta

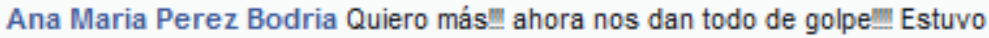
sensacionalE

26 de abril de 2013 a la(s) 2:02 - Me gusta

Fabiana Romero Julián se queda con gisela .,brinda con lucas

26 de abril de 2013 a la(s) 2:03 - Me gusta

María José Cuello excelente

6.5 26 de abril de 2013 a la(s) 2:04 - Me gusta

Yamila Marcela Banti Espero que Julian se quede con Gisela y no con la estupida de Natacha!

26 de abril de 2013 a la(s) 2:05 - Me gusta

(3)

Fabiana Romero $\mathrm{Y}$ obviamente viky con marcos.elena con pele............

26 de abril de 2013 a la(s) 2:05 - Me gusta

89

Florencia Rumbo atrapan a Rensi, gracias a Gabriela y a Somosa que lo engaña para que caiga en la trampa. Santiago le cuenta a la novia de julian quien mato al padre. Aparece fredi y le cuenta la verdad del por que se habia ido Natacha.

26 de abril de 2013 a la(s) 2:05 - Me gusta

Ana Ines Medina No se que final le darán, pero sé el final que a mi me gustaría. Julián se queda con Gisella, Natacha se fue, no confió, y tuvo la misma actitud infantil que demostró durante el tiempo que estuvo. Marcos y Vicky a full juntos. Lorenzo, Angeles y Renzi a la cárcel. Elena con Pepe, los Bandi de nuevo en la fábrica y siendo cooperativa. $Y$ Brenda tiene que quedarse con Ciro $\underline{m}$ de una $\mathbf{m}$ Lucas ha procedido mal reiteradas veces, y por más justificativos y excusas que ponga Lucas es un infantil e inmaduro total, ademas no la merece a Brenda. Por favor, que Brenda siga con Ciro, de otro modo se hará una apologia de los cuernos y la sumision femenina perdonando una y otra vez

26 de abril de 2013 a la(s) 2:05 - Me gusta - $\$ 4$

Daniela Zuk Que no termineeee..․ㅡㄹ

26 de abril de 2013 a la(s) 2:05 - Me gusta - $\mathbf{B} 1$

Imagen del Facebook oficial de Dulce Amor (Abril 2013) 
Otro caso ocurrió con la tira Farsante, en medio del malestar de las fanáticas porque asesinaron a uno de los protagonistas. La vuelta del actor por solo una escena, para que se reencuentre y despida de su pareja en la ficción, generó polémica entre las audiencias/usuarios, que se intensificó con el interrogante acerca de la aparición de Benjamín Vicuña (Pedro).

Esta clase de preguntas, no es inocente, se desarrollan en el marco de un clima de tensión, enfado, de las fanáticas cuando se terminó la pareja de Pedro y Guillermo, causada por la muerte trágica de Pedro. Las audiencias/usuarios de la ficción estaban expectantes ante los rumores de una posible participación, transcurrido unos meses de haber abandonado la tira. Cuando la noticia se confirmó, por parte de la producción y el actor, se generaron numerosos debates sobre si era apropiado o no, donde se dejaron vislumbrar diversas opiniones, a favor y en contra. 
Puxing Farsantes - Página oficial

13 de diciembre de 2013 es

Los fanáticos opinan: ¿Cómo tiene que ser la vuelta de Pedro a Farsantes? http://www.eltrecetv.com.ar/farsantes/vuelve-benjamin-vicuna-vuelve-

pedro_065882



(1) A 854 persongs les gusta esto.

[1. Ver comentarios anteriores

Bella Monyka no, no puede volver!!!!! esta muerto.la vida continua y guille tiene que terminar con jose.

13 de diciembre de 2013 a la(s) 21:11 - Me gusta ' $B 6$

2- Cecilia De Cicco No tiene que haber vuelta. pero en ese caso en los sueños de guillermo no volverlo de la muerte, ya es cuslquier cosa 13 de diciembre de 2013 a la $\{5\} 21: 13$. Me gusta is 1

7. Cecilia De Cicco DaRien Beto ya se fue y no hay vuelta atrás 13 de diciembre de 2013 a la(s) 21:13 - Me gusta

404 Veronica Val vivo! nada de recuerdos ni sueños!! LA HISTORIA DE IC. AMOR ES PEDRO-GUILLERMO.

13 de diciembre de 2013 a la(s) 21:17 . Me gusta a $b 1$ 
Elida Zárate Si no les gusta FARSANTES no lo miren.

13 de diciembre de 2013 a la(s) 21:19 - Me gusta

Lorena Lacava Felizzzz q vuelva pedroo!!!! Como sea pero q vuelva y

esten juntossss!!!!!! Pedro y guille junto son lo mas!!!!"

13 de diciembre de 2013 a la(s) 21:24 - Me gusta * 31

Vilma Andrea De Bernardi Como sea. Que vuelva. Me trago cualquiera.

Divino el!!!

13 de diciembre de 2013 a la(s) 21:25 - Me gusta * 31

Bettina Medina Garrido exacto, no lo miro..., es patético

13 de diciembre de $2013 \mathrm{a}$ la(s) 21:27 · Me gusta

Xime Fusco no lo miras pero te ocupas de entrar en la pagina y

comentar! mmmmm

13 de diciembre de 2013 a la(s) 21:29 - Me gusta

Marcela Carina Pavón Que vuelva como el hermano gemelo (:)

13 de diciembre de 2013 a la(s) 21:31 - Me gusta * 32

Lucia Tello para mi tienen que decir que pedro jamas murio ,Io tuvieron oculto porque lo culpaban una muerte que jamas cometio y para salbarlo lo escondieron ... volve pedro te esperamos

13 de diciembre de 2013 a la(s) 21:31. Me gusta * 35

Natalia Germi Yo quisiera que vuelva vivo pero suponiendo que se

ocultó de todos este tiempo por seguridad hasta que termine el juicio y se den cuenta que no es culpable, quién supuestamente lo estuvo cuidando y no lo denunció?

13 de diciembre de 2013 a la(s) 21:34 - Me gusta

Elda Ramirez pensemos jamas lo vimo muerto todo fue re rapido

tranquilamente se puede desir que esta vivo, yo en realidad lo unico que quiero es que guille termine feliz, se lo re mereceeeeeeeee

13 de diciembre de 2013 a la(s) $21: 34$ - Me gusta * B 1

7. Andrea Dominguez Q patetico, se murio y ahora vuelve? Ya es cualquier cosa esta novela, se nota q solo piensan en el rating y no en el publico xq como la novela mide ya no saben mas q inventar para estirarla. Dejense de joder y terminenla antes de q la sigan cagando

13 de diciembre de 2013 a la(s) 21:34 - Me gusta * 32

Natalia Germi sino puede volver al menos que se quede con el fiscal que parece que le interesa más que Franco.

13 de diciembre de 2013 a la(s) 21:34 - Me gusta * 34

Silvia Arce como sea pero que vuelva

13 de diciembre de 2013 a la(s) 21:35 . Me gusta ' 31

Imagen del Facebook oficial de Farsantes (Diciembre 2013) 
Como complemento a las publicaciones en Facebook, se creó un video con la compaginación de algunas de las escenas románticas que compartía con su pareja de ficción, musicalizado con la canción característica de los personajes, con el fin de promocionar la vuelta de Pedro a la tira, alimentando la ansiedad y el cariño de los fanáticos hacia la pareja.

\section{Vuelve Benjamín Vicuña, vuelve Pedro}

Una noticia que muchas fanáticas esperaban con ansiedad: Benjamín Vicuña vuelve a Farsantes para grabar más escenas de esta historia de amor que crearon con el personaje de Iulio Chávez.

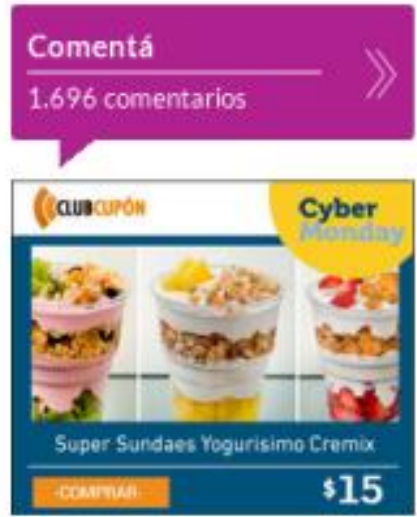

\section{Más de Farsantes}

2. El backstagefinal de Farsantes
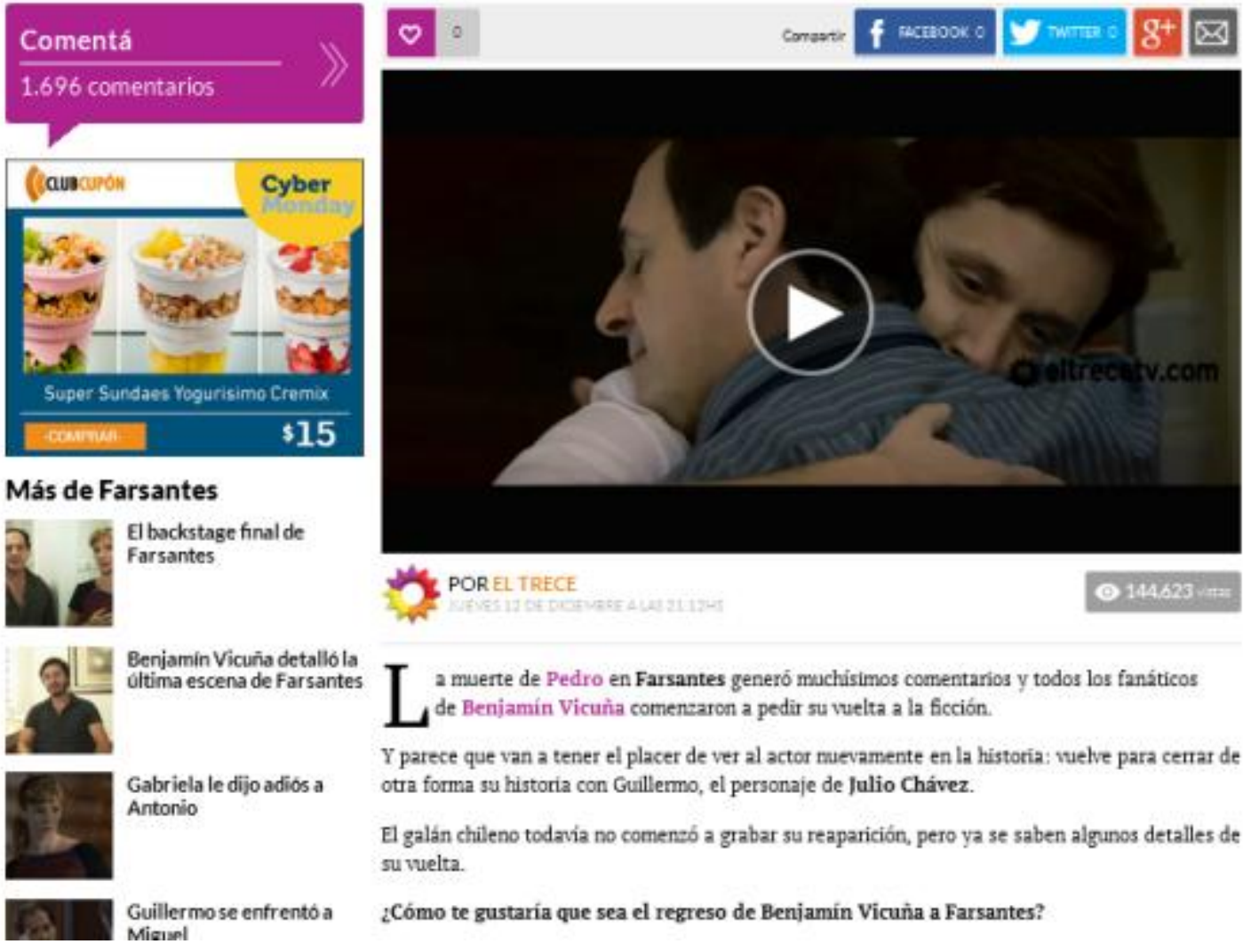

\footnotetext{
T a muerte de Pedro en Farsantes generó machisimos comentarios y todos los fanáticos de Benjamin Vicuna comenzaron a pedir su vuelta a la ficción.

Y parece que van a tener el placer de ver al actor nuevamente en la historia: vuelve para cerrar de otra forma su historia con Guillermo, el personaje de Julio Chávez.

El galán chileno todavia no comenzó a grabar su reaparición, pero ya se saben algunos detalles de su vuelta.

¿Cómo te gustaría que sea el regreso de Benjamin Vicuña a Farsantes?
}

http://www.eltrecetv.com.ar/farsantes/vuelve-benjamin-vicuna-vuelve-pedro 065882 
Por su parte, en la tira Guapas, utilizan el recurso de retomar una frase que se dijo en la tira, repreguntando a las audiencias/usuarios, incentivándolas a participar. Este tipo de preguntas genera curiosidad, potenciando el deseo de querer mirar o volver a ver la escena en la que el personaje Donofrio expresó dichas palabras.

Guapas

29 de octubre 10

¿A quién no le gustaría tener enfrente a un hombre asi?

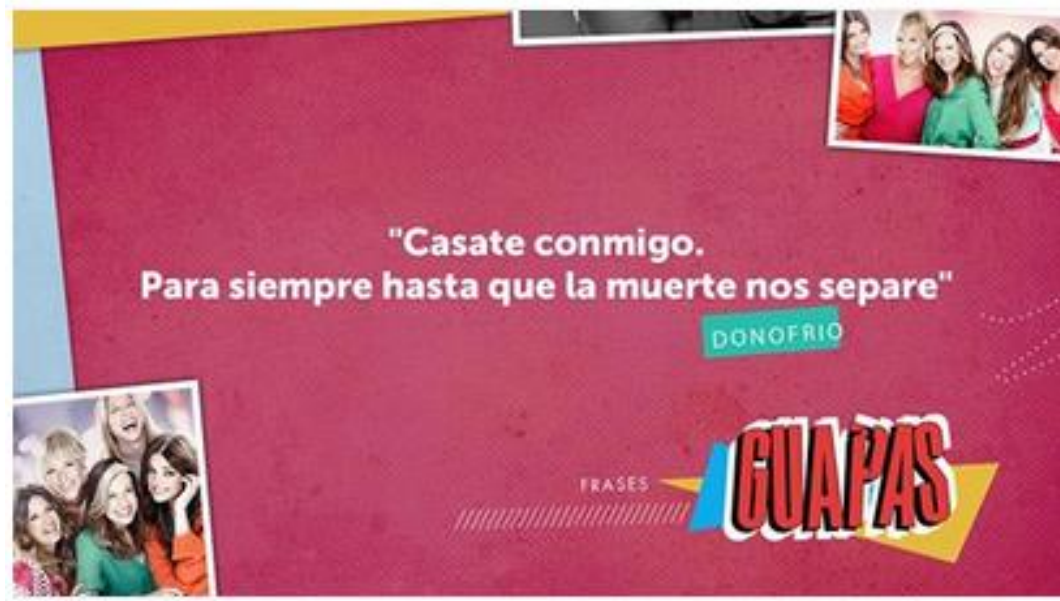

Me gusta Comentar Compartir

$\Rightarrow$ Compartida 1886 veces

I3 A 22545 personas les gusta esto.

Mejores comentarios *

Escribe un comentario.

16. Paz De los Santos Donde se consigue un Donofrio ?????

Me gusta - Responder B 132 - 29 de octubre a la(s) $11: 14$

ㅁ. 12 respuestas

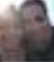

Bianca Peralta ami mi marido me dijo, -no mires tanto, ni creas en lo que dice rulos falta que quieras que te proponga lo mismo- jajaj tenia ganas de matarlo, jajaja

Me gusta Responder $B 112 \cdot 29$ de octubre a la(s) 11:19

므 9 respuestas

Daniela Brunori Ohhhhhhhhhhhhhhhhhhhhhhhhh solo en novelas pasa..

Me gusta Responder a $18 \cdot 29$ de octubre a la(s) 11:14

10. Romi Pelozo Por suerte tengo la dicha de tener un donofrio a mi lado:)

Me gusta Responder ' $B$ 14:29 de octubre a $\mid a(s)$ 11:21 
Cintia Daniela ya no existen hombres asiii !

Me gusta - Responder ' $35 \cdot 29$ de octubre a la(s) 19:11

Natalia Acosta Solo pasa en la vida ficticia de novelas o películas!! (:)

Me gusta - Responder · $34 \cdot 29$ de octubre $a \operatorname{la}(s)$ 19:21

4. Viviana Colmán Novaro Creo q siempre hay un Donofrio $x$ ahí para cada

(A) una, solo hay q saber mirar, los demás son solo enseñanzas q nos da la vida!

Me gusta · Responder ' $34 \cdot 29$ de octubre a la(s) 12:22

군 Eva González Dios te oiga y me lo mande cuanto antes!

Me gusta $\cdot 31 \cdot 29$ de octubre a la(s) 12:24

- Susana Gonzalez Yo donde estaba ?????? Me gusta $\cdot 29$ de octubre a la(s) 14:32

T.

Escribir una respuesta.

Blanki Pereira es la mas linda declaracion d amor q vi...

Me enamore d donofrio nuevamente!!

Me gusta - Responder ' $34 \cdot 29$ de octubre a la(s) 11:30

Georgi Bellomi Hasta las lágrimas anoche con Donofrio! \

Me gusta - Responder ' $34 \cdot 29$ de octubre a la(s) 11:29

Mariela Principe Solo en las novelas pasa eso !!!!!!!!

Me gusta - Responder ' 34 . 29 de octubre a la(s) 11:22

Isabel Diaz Vera ¡Me morí de amor! ¡Si Donofrio, todas, junto con Mey.

te contestamos que siiii! jajaja

Me gusta · Responder ' $38 \cdot 29$ de octubre a la(s) 11:28

- Susana Gonzalez Ya !!!!!

Me gusta $\cdot 31 \cdot 29$ de octubre a la(s) 14:30

18. Escribir una respuesta

Mariela Pons "Para siempre y hasta que la muerte nos separe"...sere un bicho raro, pero a mi me resulta intimidante esa frase, como en la epoca de nuestras madres, que se tenian que casar y una vez que eligieron no habia vuelta atras. La verdad que hubiera preferido que digera algo asi como "Casate conmigo y volvamos a elegirnos cada dia".

Me gusta - Responder ' $33 \cdot 30$ de octubre a la(s) $2: 31$

\section{Imagen del Facebook oficial de Guapas (Octubre 2014)}


La realización de entrevistas en vivo, en un día y horario pautado, a través de la web oficial de un canal de tv, forman parte de una estrategia. La posibilidad de acercar virtualmente al artista con un fanático, compartir un momento, poder hacerles preguntas profesionales y personales, conocer más de su actor o actriz favorito, genera y potencia el interés de las audiencias/usuarios.

La combinación de diferentes plataformas digitales facilita la concreción de la entrevista, permitiendo el acceso y conexión de fanáticos que viven en diferentes lugares del país y del exterior, que siguen la novela a través de Internet, y que pueden disfrutar de la iniciativa.

La era de los hipermedios posibilita un modelo de comunicación que se desarrolla desde una plataforma digital pero que requiere la participación de los usuarios, consolidando un proceso de intercambio y producción.

Asimismo, este tipo de entrevistas virtuales permite la coexistencia entre un recurso tradicional como es la entrevista pero dentro de un formato interactivo, creando un escenario donde convergen diversos lenguajes, debido a que las audiencias/usuarios deben hacer sus preguntas en una plataforma digital, diseñada especialmente para dicha entrevista.

Por lo tanto, las estrategias de los canales de televisión también hacen uso de viejos lenguajes, técnicas, pero modernizándolas, renovándolas desde una mirada digital, caracterizada por la interactividad y lo multimedial.

Los fanáticos de la tira Guapas, tuvieron la posibilidad de participar en una entrevista virtual a uno de los actores de la tira Alberto Ajaka (Donofrio), escribiendo sus preguntas en el sitio web del canal El Trece Tv. La promoción de la entrevista se realizó en la web del canal con un video del actor, invitando a participar publicando sus preguntas y prometiendo que las iba a responder. También, la convocatoria se hizo en el Facebook oficial de la ficción. 


\section{Tenés una cita con Donofrio: ¿Le vas a fallar?}

Este jueves 18 de septiembre a las 16:00, Alberto Ajaka -que personifica a Alberto Ajakaen Guapas- estará en la entrevista en vivo por Eltrecetv.com. ¿Ya le dejaste tu pregunta? Mirá la invitación que te hace:

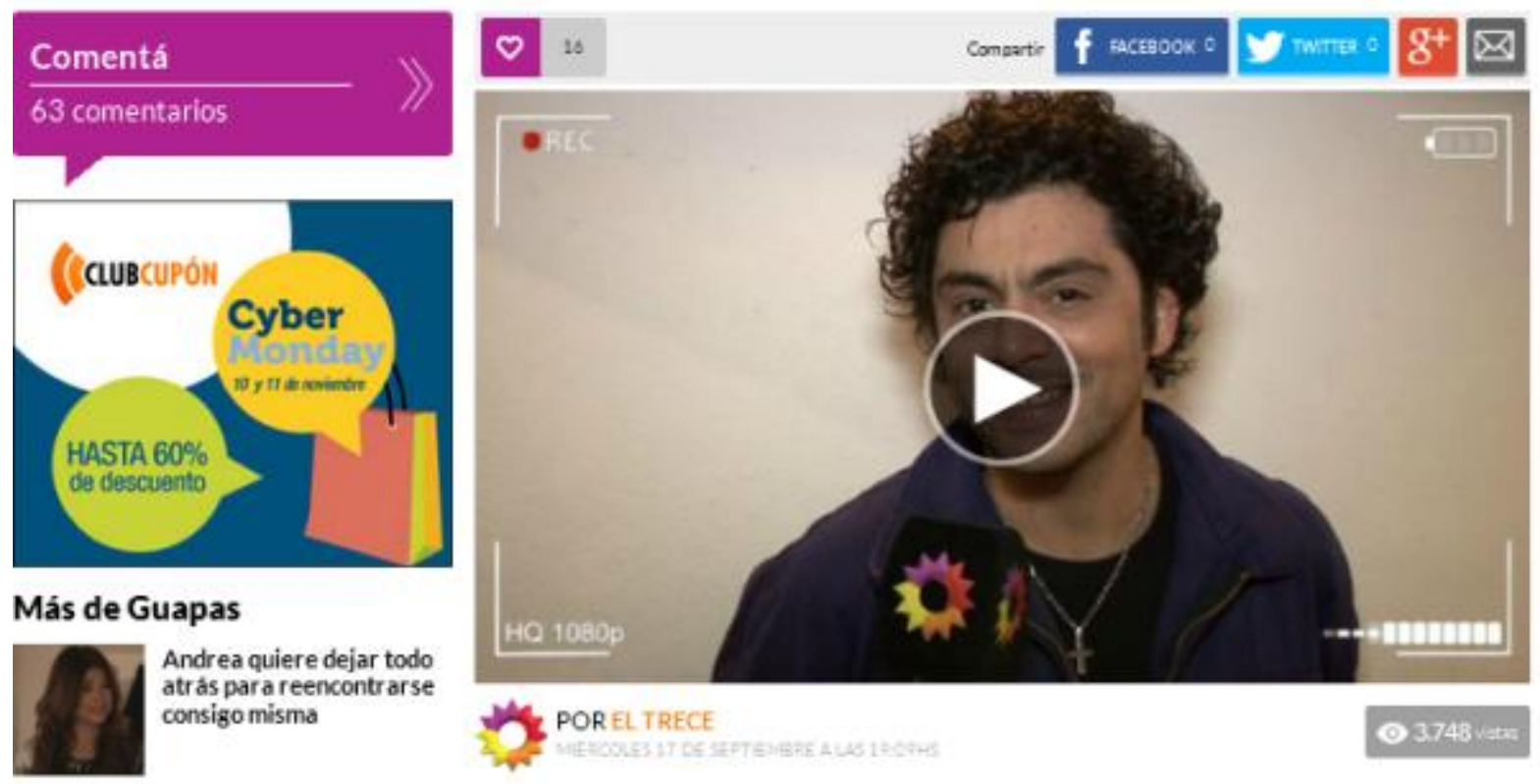

http://www.eltrecetv.com.ar/guapas/tenes-una-cita-con-donofrio-le-vas-fallar_072181 


\section{Guapas \\ 18 de septiembre $\theta$}

Ya empezó la entrevista a Alberto Ajaka! Mirala acá!

http://www.eltrecetv.com.ar/entrevistas

Me gusta - Comentar - Compartir B677 $\square 17 \Leftrightarrow$ Compartida 2 veces

A 677 personas les gusta esto. Mejores comentarios *

38. Escribe un comentario...

LE. Dolores Quinteros Que buen actor que sos y que buena pareja con peterson

. Me gusta - Responder - $\$ 3$ - 18 de septiembre a la(s) 21:03

13 Stellita Maris Borgatta -Muy buena entrevista la pasaban en canal 13, pero no. La transmitieron en el trecetv, que recién me entero que son cosas diferentes.

Me gusta - Responder - $\$ 3$ - 18 de septiembre a la(s) 17:51

9. Yanii Tello Suares no lo puedo ver desde el cel $\mathbf{m}=$

Me gusta - Responder - $\$ 1$ - 18 de septiembre a la(s) 17:14

Melina L. G. Martinez Sos hermoso0000000000

Me gusta - Responder - 18 de septiembre a la(s) 20:15

Silvia Bauer Morochon hermoso

Me gusta - Responder - 18 de septiembre a la(s) 18:16

D. Sil Iriarte Muy buena yo la pude ver desde el celu

Me gusta - Responder - 18 de septiembre a la(s) 18:06

Klau Rotela Re canchero Donofrio

Me gusta - Responder - 18 de septiembre a la(s) 17:55

8.4 Doryta Teyo Donde la estan dando ????????? XFA AVISEN

Me gusta - Responder - 18 de septiembre a la(s) 17:53

Maria Cembola Si lindo

Me gusta - Responder - 18 de septiembre a la(s) 17:52

Imagen del Facebook oficial de Guapas (Septiembre 2014) 
Anteriormente expuse estrategias diseñadas, creadas por el Departamento de Tecnología de los canales de televisión. Sin embargo, es necesario analizar cuando ocurre el proceso inverso, es decir, cuando el canal se apropia de un producto que se gestó entre las audiencias/usuarios, haciendo uso de la producción de un texto que se generó por ellas, para la circulación e identificación entre los fanáticos.

Lo novedoso radica en la circulación y el alcance que un caso de narración transmediática puedo lograr a partir del avance de la tecnología y la consecuente creación de plataformas que permiten alojar y promocionar estos productos.

Los cambios tecnológicos y las nuevas formas de acceso, participación y visibilidad que disponen las audiencias/usuarios, dan lugar a transformaciones en la implementación de nuevas estrategias comunicacionales por parte de los canales de televisión.

En la tira Camino al Amor, las audiencias/usuarios crearon el término Rolena (unión de los nombres de los personajes que componen una de las parejas protagónicas de ficción), Sebastián Estevanez (Rocco) y Carina Zampini (Malena) como una manera para denominarlos. Dicha palabra se gestó en las redes sociales, y comenzó a circular entre las audiencias/usuarios.

Lo paradigmático radica en que Rolena fue retomado por el Departamento de Tecnología de Telefe, no solamente en las publicaciones en Facebook sobre la pareja (adelantos, fotos, videos), sino que también en el sitio web del canal, donde se pueden visualizar imágenes y videos de las escenas que protagonizan juntos. 


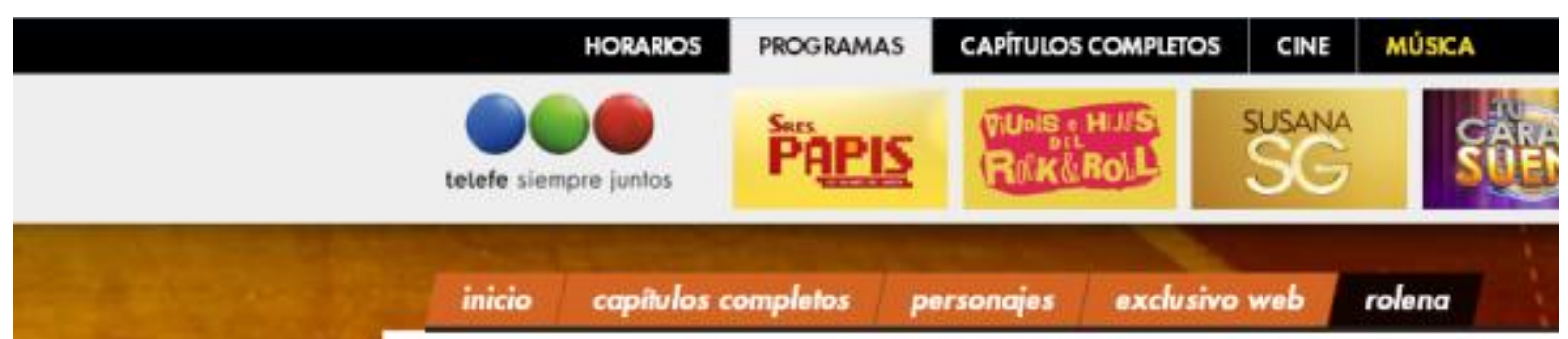

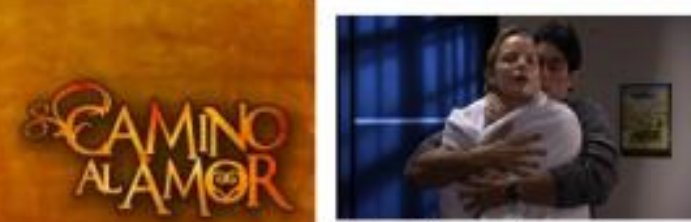

\#ZampiVanez tiene aguante

La pareja que nacio en Franco

Buenaventura, conquistó el amor

del púbico que lo sigue

apasionadamente. ¿Qué tiene de

especial?

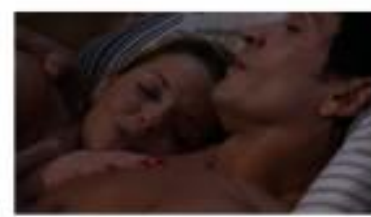

¡Rolenazo! Por fin viven su noche de pasión

Rocco y Malena afianzan su amor y disfrutan intensamente de un momento funtos.

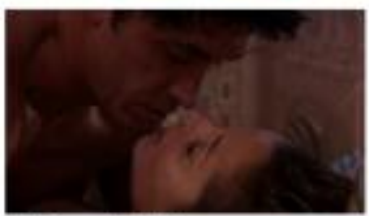

\#Rolena: Pasión en aumento

Rocco y Malena se liberaron y viven su intenso amor. La pareja del momento da rienda sueta al deseo $y$ al desenfreno.

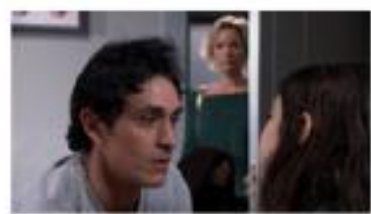

Rocco le promete a Wendy permanecer a su lado ¿y junto a lupe?

Esta promesa es escuchada por Malena. ¿Podrá Rolena resistr esto?

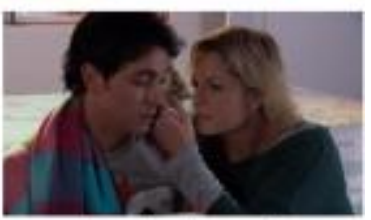

Las mejores imágenes de \#Rolena

Su amor rompe todos los récords en tu corazón. Mirás a galería de Rocco y Malena.

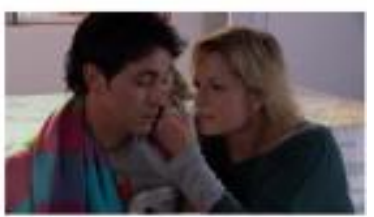

Rocco debe elegir entre Malena o Wendy

Lupe amenaza con no permitirla volver a ver su hija. Malena bo insita a luchar por el amor de su hj̃a. 
La industria televisiva argentina se apropia de herramientas digitales que incentiven y seduzcan a las audiencias/usuarios con sus participaciones. En este sentido, existe un desarrollo de estrategias comunicacionales tendientes a captar la atención de las audiencias/usuarios, con el objetivo de buscar la complicidad para conseguir incrementar la participación de aquellos que siguen una determinada ficción, sumado al interés de las audiencias/usuarios de tener a su alcance los contenidos y disponer de ellos de acuerdo a sus propios tiempos.

Tanto Telefe y El Trece Tv presentan además de los Facebooks Oficiales de las tiras y el sitio web del canal, cuentas en Youtube; en los tres escenarios se cargan los capítulos de sus ficciones, una vez que fueron transmitidos. Demostrando cómo las industrias televisivas apostaron a Internet para consolidad sus estrategias competitivas y de posicionamiento.

La interconexión es una de las características fundamentales para llevar a cabo una estrategia de expansión, al igual que la convergencia multimedia entre todos aquellos medios que dispone el canal con el fin de conseguir que las audiencias/usuarios se vean implicadas en una red persuasiva que las conduce de un sitio a otro siempre en relación con un contenido que es de su interés.

Por último, estas estrategias pretenden generar y fortalecer un escenario en el que las audiencias/usuarios que acostumbran a seguir una tira, logren un acceso y comunicación con sus pares, creando una falsa proximidad entre los seguidores de un mismo contenido; sabiendo que las audiencias/usuarios son actualmente más expertas en el uso de los medios digitales, razón por la cual los canales de televisión pretenden aprovechar en su beneficio esta mayor experiencia. 
CONCLUSIONES 
Una vez finalizada el trabajo de campo y la experiencia de recorrer y describir los ejemplos del estudio de caso, decidí detenerme en algunos ejes que he analizado a lo largo del estudio con la finalidad de abrir nuevas líneas a desarrollar en futuras investigaciones que puedan profundizar los usos de las redes sociales en la configuración de las audiencias televisivas de ficciones.

Desde identificar las características de las ficciones seriadas argentinas, pasando por considerar a Facebook como un espacio de debate, expresión y configuración de grupos que se interpelan como audiencias/usuarios, los sentidos que ellas le otorgan a las tiras, sus intervenciones intentando provocar cambios en el desarrollo de las ficciones, la identificación con situaciones, personajes pertenecientes a una tira, hasta las estrategias de comunicación que utilizan los canales de televisión a través de Facebook para con sus audiencias/usuarios, puedo afirmar que este ejercicio investigativo logró analizar, desarrollar y profundizar cada uno de los objetivos propuestos en la tesis.

Asimismo, la investigación permite, a partir de la observación y descripción de determinadas prácticas aportar conocimientos, características, nociones sobre lo que ocurre en el Facebook de una tira, pero también lo que se origina en el y trasciende a otras plataformas digitales.

La observación flotante posibilitó el recorrido de numerosos Facebooks, publicaciones, imágenes, fotos, videos, entrevistas, artículos, caracterizado por la exploración y descripción. La metodología escogida permitió llevar a cabo un análisis de cada una de las publicaciones estableciendo como limite la creación de la categorización de diferentes núcleos temáticos que se desprendieron de los objetivos de la investigación. La elección de la observación flotante fue positiva para conocer los cambios producidos en el acceso y consumo de las ficciones argentina, gracias al avance tecnológico que ha permeado la vida cotidiana. 
El progreso tecnológico ha operado cambios en la comunicación; surgiendo otras formas de comunicar, nuevos formatos y plataformas de expresión que modifican la relación de las audiencias/ usuarios con los medios.

En este contexto era necesaria la búsqueda de un término que pudiera describir las mutaciones que sufrieron las audiencias, adquiriendo un papel multifacético, convirtiéndose en consumidoras y productoras, por este motivo, el término audiencias/usuarios es pertinente para describir el rol que asumieron, aclarando que por convertirse en usuarios no dejaron de ser audiencias.

La convergencia mediática activó en las audiencias/usuarios distintas maneras de consumo y de uso en forma simultánea con prácticas de producción e interacción. El contenido está disponible, a su alcance, cuando, donde, y en la plataforma que lo desean, implicando a las audiencias/usuarios en una red de medios, que las seduce permanentemente y que las convoca a interactuar con sus pares. Destacando que el traspaso de una comunicación lineal a una interactiva, es un cambio significativo en el comportamiento de los usuarios.

En este contexto mediado por la convergencia se generan modificaciones en la forma de elaboración y distribución de las ficciones de un canal de televisión, focalizando en cómo entregar un determinado contenido y en qué velocidad. La evolución constante de la era digital se convierte en una alarma para las industrias, que deben reinventarse permanentemente, para lograr un carácter distintivo dentro del mercado.

El diseño y la producción de una estrategia comunicativa que posibilite una comunicación multidireccional a través del uso de multiplataformas destinadas a una ficción, es el objetivo a alcanzar por las industrias televisivas. En la actualidad es imposible pensar en un canal de televisión que no disponga de redes sociales, para promocionar los contenidos del canal y de esta modo generar el interés de los usuarios y la consecuente participación en las redes específicas que poseen sobre cada programa de televisión. 
Sin lugar a dudas, las redes sociales poseen actualmente un destacable protagonismo, convirtiéndose en una herramienta comunicacional fundamental, ofreciendo garantía de interacción entre un producto televisivo y sus audiencias/usuarios. Potenciando la emergencia de nuevos modos de percibir y participar, la interactividad digital, la visibilidad constante, y la producción y circulación de diversas narraciones.

Entiendo a las redes como un espacio de comunicación que posibilita la interacción de un grupo de audiencias/usuarios alrededor de un producto televisivo, que lo interpela, moviliza, provocando en ellas alguna reacción que pueda exteriorizar por medio de un comentario.

Una red social como Facebook es un medio de comunicación, de información y distribución imponente, en el que convergen medios tradicionales y nuevas plataformas digitales. A través del Facebook oficial de una tira, se explotan al máximo las cualidades y ventajas comunicativas/publicitarias de la red social, consiguiendo beneficios en cuanto a la relación directa que se puede establecer con las audiencias/usuarios.

Las diversas aplicaciones interactivas disponibles en ficciones televisivas permiten la constitución de una segunda pantalla al poder recibir contenidos en diversos dispositivos electrónicos, con enlaces que permiten dirigirse a las redes sociales para seguir comentando sobre la ficción. Una segunda pantalla donde el objetivo principal sea expandir la experiencia de ver televisión logrando que sea más social e interactiva, a partir de la participación de la audiencia en dicha plataforma.

Las audiencias/usuarios se configuran dentro de Facebook, se construyen a partir de los usos que le otorgan a esta red social, con sus propios comentarios sobre la ficción que están mirando, criticando, elogiando, debatiendo, opinando, en definitiva interpelando contantemente lo que le ofrece la tira. También, utilizan este espacio para dar a conocer otras redes sociales o sitios webs que se desprenden de la ficción. 
Como expuse en el trabajo de campo, son variados los usos que las audiencias/usuarios hacen de un Facebook oficial, los cuales funcionan como una ventana al exterior, expuesta de mensajes centrados en un tema, en donde las audiencias/usuarios interactúan o simplemente se limitan a leer las publicaciones ajenas, sin dejar rastros de su participación. La productividad de un Facebook dedicado a una tira, radica en los mensajes, debates, comentarios que se exponen, debido a que es lo que determina la vitalidad de la red social y la construcción, consolidación de las audiencias/usuarios.

Las nuevas tecnologías potenciaron y cambiaron las prácticas de las audiencias/usuarios, en el marco de un espacio digital en permanente fluctuación, heterogéneo y complejo, ligado a lo inmediato y lo virtual, fortaleciendo un aspecto interactivo de la comunicación, para la producción, circulación y distribución de los contenidos. Haciendo uso de los contenidos a través de las multipantallas, la cantidad de veces que lo desee.

Las narraciones transmediaticas son un ejemplo de esta situación, en donde a partir de una historia narrada en una ficción de televisión, o algún personaje en particular, se crea un nuevo producto, que gracias a las diversas plataformas digitales puede darse a conocer, se puede compartir con sus pares, creando universos alternativos.

El mundo paralelo creado a partir de las narraciones trasmediáticas, que años atrás estaba oculto o no tenía la posibilidad de trascender, en la actualidad, en un contexto mediado por las multiplataformas pudo dar a luz, difundirse a través de las redes sociales, impensado en décadas anteriores.

De esta manera, las redes sociales se convierten en espacios virtuales organizados para desarrollar proyectos, integrar comunidades, proyectándose hacia el mercado global, utilizando de este modo, toda la potencia de la virtualidad. 
El progreso del entorno tecnológico pone al alcance de las audiencias/usuarios mecanismos que se caracterizan por sus posibilidades multimediales (integración de videos, imágenes, narraciones), creando modos de expresión e interacción que se aleja de los tradicionales, propios de la comunicación analógica.

Las redes sociales sobre las tiras posibilitan la difusión de la información y la conquista de numerosas audiencias/usuarios, creando una comunidad virtual participativa, logrando que esas mismas redes estén en constante movimiento, gracias a los usos otorgados por las audiencias/usuarios.

A modo de cierre, me interesa rescatar datos que se desprendieron del trabajo de campo, aclarando que miré cada una de las ficciones mencionas, desde el primer capítulo, debido a que considero que como investigadora debía conocer el texto para poder comprender el sentido de la interacción.

- El contenido publicado en el Facebook Oficial es comentado por las audiencias/usuarios, generalmente durante dos días posteriores a la fecha de su publicación.

- Si bien participan audiencias/usuarios identificadas como hombres, la mayoría de personas que opinan, discuten sobre alguna situación o personaje de la tira son mujeres.

- A pesar de que los Facebooks oficiales de una tira conserven el predomino de audiencias/usuarios nacionales, no dejan de ser redes sociales globales, en la que 
participan audiencias/usuarios de otros países, como Uruguay, Paraguay, España, entre otros, quienes siguen la tira a través de diversas sitios web donde suben los capítulos, debido a que todavía la tira no fue comprada en su país de origen o porque es emitida con retraso respecto Argentina.

- Los comentarios que publican las audiencias/usuarios pueden responder a un mensaje anterior o no presentar relación con el debate que se está generando.

- Los debates que convocaron la mayor cantidad de comentarios y discusiones son en general sobre cambios abruptos de la historia, la ida de un artista y como consecuencia la culminación de una historia, y la incorporación de un nuevo personaje que según las audiencias/usuarios les quita escenas a los personajes que comenzaron desde un comienzo.

- Cuando finaliza una emisión, se producen debates, reflexiones acerca de algunos temas desarrollados en el capítulo. Los principales tópicos retomados son: el amor, la muerte, la felicidad y la infidelidad. Además, a través de ciertos comentarios hacen un paralelismo y narran experiencias vividas.

- La identificación es una constante que se desprende de las publicaciones que realizan las audiencias/usuarios, con un personaje en particular, su forma de ser, acontecimientos que atraviesa, o también con algunas situaciones que se narran dentro de una ficción. 
- Cuando hacen uso del Facebook para realizar algún reclamo en particular, se dirigen a los autores, productores y al canal de televisión que emite la ficción. Frases como $-\mathrm{Si}$ nosotras no son nada", -Como nos faltan el respeto", Es la última vez que miro una ficción de tal productor... siempre arruina las historias", son habitúes entre los comentarios que dejan en la red social.

- A partir de una ficción puntual, se crean otros Facebooks para debatir sobre la tira, que retoman publicaciones, adelantos, imágenes, que son difundidos por las audiencias/usuarios en el Facebook Oficial o en el sitio web del canal de televisión que emite la tira. Sin embargo, estos Facebooks periféricos no llegan a tener los numerosos comentarios que presenta el oficial.

- Un dato a colación, es que hasta el día 13 de noviembre de 2014, la cantidad de $\mathrm{Me}$ gusta" que tiene cada Facebook oficial de las tiras que analicé en el trabajo de campo es (el número no representa la cantidad de audiencias/usuarios que publican en dicho Facebook):

Farsantes (El Trece Tv): 39.343

Guapas (El Trece Tv): 1.144 .921

Dulce Amor (Telefe): 506.114

Camino al Amor (Telefe): 27.844

- Uno de los momentos más celebrados por las audiencias/usuarios, son las entrevistas virtuales realizadas a un artista de una ficción. Ellas agradecen a la producción de la tira, por permitirles conocer, conversar por un momento, con su actor o actriz favorita. Permitiéndoles conocer más sobre su vida, y también sobre la psicología del personaje 
que interpreta.

- Una vez que finaliza la ficción, el Facebook es utilizado como medio para difundir algún tipo de noticia sobre un premio o reconocimiento que obtuvo la tira o un artista de la misma, para promocionar una nueva ficción del canal, intentando persuadir, atraer a las audiencias/usuarios hacia la tira próxima a estrenarse. Sin embargo, con el paso de los meses se dejan de realizar publicaciones aunque no se cierra la página de Facebook creada.

- Un caso de narraciones trasmediáticas que se repite constantemente son los videos musicales que realizan las audiencias/usuarios sobre una pareja de ficción. La recopilación, edición y musicalización son realizadas por ellas, haciendo uso de Facebook o Youtube para difundirlas entre sus pares, recibiendo comentarios de elogios y agradecimientos, y también sugerencias para la edición de nuevos videos, como canciones que disponen de una letra que representa la historia de la pareja de ficción, hasta programas que permiten editar con una mejor calidad y definición de imágenes. A las narraciones trasmediáticas que hago referencia son a las que se desprenden de una ficción puntual, aclarando que hay diferentes clases de narraciones trasmediáticas, que surgen permanentemente.

La velocidad e inmediatez que presenta la era digital, con la aparición constante de nuevas plataformas y redes sociales, crean el prejuicio que cualquier investigación abocada a esta temática disponen de una corta vigencia.

Sin embargo, considero que es necesario continuar estudiando los usos que las audiencias/usuarios les otorgan a las redes sociales, avanzando de este modo en la construcción de nuevos marcos teóricos y metodológicos que puedan dar cuenta de este fenómeno, debido a que 
en un futuro, las investigaciones actuales serán constitutivas de todos los procesos que surgieron en el escenario digital.

En este sentido, no tenemos que dejar amedrentarnos por el desarrollo incesante de la tecnología. Por consiguiente, es importante comprender la variedad de maneras en que los medios nuevos y los antiguos se adaptan unos a otros y conviven en formas simbióticas y las formas en que convivimos con ellos. Haciendo foco en cómo la comunicación en red se reinventa permanentemente.

No debemos hacer ninguna clase de futurología sobre cómo se van a seguir desarrollando estos procesos, sobre que plataforma o red social persistirá y cual no, lo que debemos es insistir en crear, avanzar sobre nuevas líneas de investigación que den cuenta de este fenómeno. Si esta temática nos interpela, tenemos la obligación de seguir estudiando los usos, las apropiaciones que las audiencias/usuarios hacen de las redes sociales, que seguramente cambiarán, se modificarán y aparecerán nuevos usos, pero eso forma parte del futuro. Por lo tanto, es necesario focalizarse en la actualidad para describir y analizar todos estos procesos que nos atraviesan de algún modo. 
BIBLIOGRAFIA 
Alastruey, Rosaura (2010): El networking. Barcelona: Editorial UOC.

Aprea, Gustavo y Soto, Marita (1998): - Felenovela, telecomedia y estilo de época. El sistema de géneros narrativos en la Argentina hoy", Ponencia presentada en el IV Congreso de la Asociación Latinoamericana de los Investigadores en Comunicación (documento en línea) http://www.semioticasteimberg.com.ar/comisiones/comisionbase.php?c=15

Barbero, Jesús Martín (1983): Memoria narrativa e industria cultural”, en Revista Comunicación y Cultura No 10, Vol. 10, México, pp 70.

Gustavo Gili, pp 309.

(1987): De los medios a las mediaciones. Barcelona: Editorial

Muñoz, Sonia (1992): Televisión y melodrama: géneros y lecturas de la telenovela en Colombia. Texas: Tercer mundo editores, pp 5.

(2011): - Riebicando el campo de las audiencias en el descampado de la mutación cultural", en Jacks, Nilda (coord.) Análisis de recepción en América Latina: un recuento histórico con perspectivas al futuro. Quito: Quipus-CIESPAL, pp. 457.

Boyd, Danah., Ellison, Nicole (2007): -Social network sites: Definition, history and scholarship", en Journal of Computer-Mediated Communication.

Brambilla Ana, Jornalismo", en Para entender as mídias sociais (documento en línea) http://issuu.com/anabrambilla/docs/paraentenderasmidiassociais

Brooks, Peter (1974): -Une esthétique mélodrame de l'étonnement: le mélodrame”, en Poétique $\mathrm{N}^{\circ} 19$.

Carlón, Mario (2012): En el ojo de la convergencia. Los discursos de los usuarios de Facebook durante la transmisión televisiva de la votación de la ley de matrimonio igualitario", en Carlón Mario, Fausto Neto Antonio. La política de los internautas. Nuevas formas de participación. Buenos Aires: La Crujia Ediciones, pp.173 - 194.

Castañeda, Linda., González, Víctor., Serrano, José (2011): Đonde habitan los jóvenes: precisiones sobre un mundo de redes sociales", en Martínez Francisco, Solano Isabel. Comunicación y relaciones sociales de los jóvenes en la red. Alicante: Marfil, pp 48. 
Castells, Manuel (2000): Conferencia inaugural del Programa de Doctorado en la Sociedad de la Información y del Conocimiento de la Universidad Oberta de Catalunya. Barcelona.

Alianza Editorial V.1.

(2001): La era de la información. Economía, sociedad y cultura. Madrid:

Madrid: Areté.

(2001): La galaxia Internet. Reflexiones sobre Internet, empresa y sociedad.

(2009): Comunicación y poder. Madrid: Alianza Editorial S.A

Christakis, Nicholas., Fowler, James (2010): Conectados. Madrid: Editorial Taurus, pp 21.

Da Matta, Roberto (1985): A casa e a rua. Espaço, cidadania, mulher e norte no Brasil. Sao Pablo, pp 96.

Da Porta, Eva (2011): Procesos de mediatización y constitución de subjetividades. El caso de los jóvenes de Km. 8. Argentina. Director: Sandra Carli. Tesis doctoral. Universidad Nacional de La Plata. Facultad de Periodismo y Comunicación Social.

De Alsola, Julián (2011): Las Redes Sociales satisfacen necesidades básicas (documento en línea) http://www.slideshare.net/Julianalsola/las-redes-sociales-1649666

Fernández Hermana, Luis Ángel (2008): Investigar en tiempos de crisis y... redes (documento en línea) http://www.madrimasd.org/informacionIdi/analisis/opinion/ opinion.asp?id=37289

Fuenzalida, Valerio (2002). Televisión abierta y audiencia en America Latina", en Enciclopedia Latinoamericana de sociocultura y comunicación. Volumen 30. Buenos Aires: Grupo Editorial Norma, pp. 9 -20.

García Fanlo, Luis (2012). Twitter y la rebelión de los ciberfans de Gran Hermano 2.0". En Las Políticas de los internautas”. Buenos Aires: La Crujía, pp. 110.

Giroux, Henry (1981): Ideology, Culture and the process of schooling. Philadelphia: Temple University Press.

Grimson, Alejandro., Varela Mirta (2002): Eulturas populares, recepción y política. Genealogías de los estudios de comunicación y cultura en la Argentina", en Mato, Daniel (Coord.): Estudios y Otras Prácticas Intelectuales Latinoamericanas en Cultura y Poder. Caracas: CLACSO y CEAP, FACES, Universidad Central de Venezuela, pp. 153-166.

Grossberg, Lawrence (1992): Estudios Culturales”. Nueva York: Routledge. 
Gruffat, Carolina., Schimkus Roberto (2010): Ła arquitectura es la política de la red. Facebook y sus rivales", en Piscitelli Alejandro, Adaime Iván, Binder Inés (Coord): El proyecto Facebook y la Posuniversidad. Sistemas operativos sociales y entornos abiertos de aprendizaje. Madrid: Editorial Ariel, pp. 74.

Gubern, Román (1974): Teoría del melodrama”, en Mensajes icónicos en la cultura de masas. Madrid: Lumén, pp. 5.

Gutiérrez, Lidia (1996): Paradigmas cuantitativo y cualitativo en la investigación socio educativa: proyección y reflexiones" en Revista Paradigma (1993-1996).

Jenkins, Henry (1992): Textual Poachers. Television Fans and Participatory Culture". London \& New York: Routledge.

(2008): - Convergence Culture. La cultura de la convergencia de los medios de comunicación". Barcelona: Paidós.

Kijkuit, Robbert (2007). Social Networks in the front end: the organizational life an idea. Rotterdam: Erasmus Research Institute of Management.

Landi, Oscar (1992): Đl televidente y su pantalla”, en Devórame otra vez. Qué hizo la televisión con la gente. Qué hace la gente con la televisión. Buenos Aires: Planeta, pp 144 154.

Longo Elía, Fernanda (1999): - Cartas a la televisión: memoria, biografía e identidad cultural", en Grimson, Alejandro y Mirta Varela: Audiencias, cultura y poder. Estudios sobre televisión. Buenos Aires: Eudeba, pp. 195.

López, Guadalupe., Ciuffoli, Clara (2012): Facebook es el mensaje. Oralidad, escritura y después. Buenos Aires: La Crujía Ediciones, pp. 14 - 33.

Mancini, Pablo (2010): Hackear el periodismo. Manual de laboratorio. Buenos Aires: La Crujia Ediciones.

Mastrini, Guillermo (2001): Eos orígenes de la televisión privada" en Revista todo es historia. Buenos Aires, pp. $18-27$.

Mazziotti, Nora (1995): Intertextualidades de la telenovela argentina: melodrama y costumbrismo", en Nora Mazziotti (comp.), El espectáculo de la pasión. Las telenovelas latinoamericanas, Buenos Aires: Colihue, pp. 153-164.

(2006): Telenovela: industrias y prácticas sociales. Bogotá: Norma. 
Moles, Abraham., Rohmer, Elisabeth (1983): Micropsicología y vida cotidiana”. México: Editorial Trillas.

Monsiváis, Carlos (1979): -Cultura urbana y creación intelectual" en Casa de las Américas. $\mathrm{N}^{\circ} 116$, pp. 84.

Moreno Acosta, Adriana (2013): Homecasting: Visualidades contemporáneas. Acerca de contenidos audiovisuales de producción casera publicados en el portal YouTube. Argentina. Director: Alfredo Alfonso. Tesis doctoral. Universidad Nacional de La Plata. Facultad de Periodismo y Comunicación Social.

Morley, David (1996): Interpretar televisión: la audiencia de Nationwide" en Televisión, audiencias y estudios culturales. Buenos Aires: Amorrortu, pp. 13 - 17.

(2008): Medios, modernidad y tecnología: Hacia una teoría interdisciplinaria de la cultura. Barcelona: Gedisa., pp. 50 - 151.

Muñoz González, Germán (2010): De las culturas juveniles a las ciberculturas del siglo XXI. Congress of the Latin American Studies Association. Toronto.

Neve, Eduardo. (2006): Exploración del espacios y lugares digitales a través de la observación flotante. Una Propuesta Metodológica”. III Congreso Online - Observatorio para la Cibersociedad (documento en línea) http://mediaccions.net/wpcontent/uploads/etnografias-digital-actas.pdf

Orihuela, José Luis (2011): Mundo Twitter. Barcelona: Editorial Alienta.

Orozco Gómez, Guillermo (1990): El niño como televidente no nace, se hace" en Educación para la recepción: hacia una lectura crítica de los medios. México: Trillas.

(1991): La audiencia frente a la pantalla. Una exploración del proceso de recepción televisiva", en Diálogos de la Comunicación y la Cultura No 30.

(2011): Ea condición comunicacional contemporánea. Desafíos de la investigación de las interacciones en la sociedad red", en Jacks, Nilda (coord.) Análisis de recepción en América Latina: un recuento histórico con perspectivas al futuro. Quito: Quipus-CIESPAL, pp. 394.

Padilla, Rebeca., Repoll, Jerónimo., González, Davis., Moreno, Gabriel., García, Hugo., Franco, Darwin., Orozco Gómez, Guillermo (2011): México: la investigación de la recepción y sus audiencias. Hallazgos recientes y perspectivas", en Jacks, Nilda (coord.) Análisis de recepción en América Latina: un recuento histórico con perspectivas al futuro. Quito: Quipus-CIESPAL, pp. 259. 
Pineda de Alcázar, Migdalia (2005): - Sociedad de la información, democratización de las comunicaciones y redefinición de las políticas de comunicación en América Latina, en la presente década". Caracas: Anuario Aninco v.17 n.1.

Piscitelli, Alejandro (2012): Prólogo, en Facebook es el mensaje. Oralidad, escritura y después. Buenos Aires: La Crujía Ediciones, pp. 9.

Prensky, Marc (2001): Đigital Natives, Digital Immigrants" en The Horizon Vol. $9 \mathrm{~N}^{\mathrm{o}} 5$. Inglaterra: MCB University Press.

Recuero, Raquel. (2009). Redes sociais na Internet. Porto Alegre: Sulina.

Sandoval, Luis (2003): Radioteatro y cultura popular: Placer y mercado en los medios de comunicación. Departamento de Comunicación Social. Universidad Nacional de la Patagonia San Juan Bosco. Comodoro Rivadavia.

Sarlo, Beatriz (1985): El imperio de los sentimientos. Narraciones de circulación periódica en la Argentina (1917-1927). Buenos Aires: Siglo XXI.

Schmucler, Héctor., Terrero, Patricia (1996): Innovaciones tecnológicas y transformación de la televisión en Argentina, en Voces y Cultura $\mathrm{N}^{\circ}$, pp. 9.

Sibilia, Paula (2008): La intimidad como espectáculo. Buenos Aires: Fondo de Cultura Económica, pp.5.

Scolari, Carlos (2008): Hacia la hipertelevisión. Los primeros síntomas de una nueva configuración del dispositivo televisivo" en Diálogos de la comunicación $\mathrm{N}^{\mathrm{0}} 77$ (juliodiciembre). Perú: FELAFACS.

(2009): Hipermediaciones. Elementos para una teoría de la comunicación digital interactiva". Barcelona: Gedisa.

Sued, Gabriela (2010): Pensando a Facebook, una aproximación colectiva por dimensiones" en El Proyecto Facebook y la posuniversidad. Sistemas operativos sociales y entornos abiertos de aprendizaje. Buenos Aires: Ariel.

Urresti, Marcelo (2008): Ciberculturas juveniles. Buenos Aires: La Crujía Ediciones.

Varela, Mirta (1998): Los comienzos de la televisión argentina en el contexto latinoamericano. Chicago: Latin American Studies Association.

(2009): Él miraba televisión, you tube. La dinámica del cambio en los medios", en Carlón, Mario y Carlos Scolari (eds.): El fin de los medios masivos. El comienzo de un debate. Buenos Aires: La Crujía, pp. 213. 
Vazza, Federico (2012): La televisión, del blanco y negro al digital. Cuaderno de cátedra del Taller de Producción Audiovisual I. Universidad Nacional de La Plata. Facultad de Periodismo y Comunicación Social.

Visón, Ivan (2010): Impacto de la promoción realizada por las empresas dominicanas a través de las redes sociales Facebook y Twitter, desde la perpectiva de los usuarios (tesis), República Dominicana. Pontificia Universidad Católica Madre y Maestra.

Watts, Duncan (2003): Seis grados: la ciencia de una edad concentrada. W. W. Norton \& Company

Weinberg, Tamar (2009): The New Community Rules: Marketing On The Social Web. Estados Unidos: O'Reilly. 